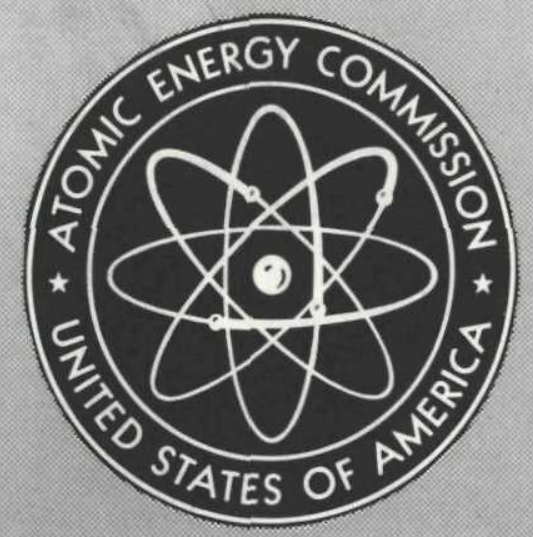

ID0-24043

SUMMARY REPORT OF DESIGN CRITERIA FOR THE LIQUID METAL PACKAGE LOOPS' HOT CELL FACILITY AND HANDLING SYSTEM AT THE ADVANCED TEST REACTOR

March 1963

Babcock and Wilcox Company

Lynchburg, Virginia

Ebasco Services Inc. New York, New York

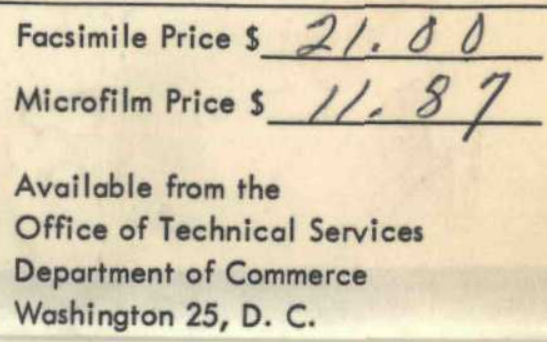




\section{DISCLAIMER}

Portions of this document may be illegible in electronic image products. Images are produced from the best available original document. 


\section{LEGAL NOTICE}

This report was prepared as an account of Government sponsored work. Nelther the United States, nor the Commission, nor any person acting on behalf of the Commission:

A. Makes any warranty or representation, expressed or implied, with respect to the accuracy, completeness, or usefulness of the information contained in this report, or that the use of any information, apparatus, method, or process disclosed in this report may not infringe privately owned rights; or

B. Assumes any liabilities with respect to the use of, or for damages resulting from the use of any information, apparatus, method, or process disclosed in this report.

As used in the above, "person acting on behalf of the Commission" includes any employee or contractor of the Commission, or employee of such contractor, to the extent that such employee or contractor of the Commission, or employee of such contractor prepares, disseminates, or provides access to, any information pursuant to his employment or contract with the Commission, or his employment with such contractor.

This report has been reproduced directly from the best available copy.

Printed in USA. Price $\$ 4.50$. Available from the Office of Technical Services, Department of Commerce, Washington 25, D. C. 


\author{
SUMMARY REPORT OF \\ DESIGN CRITERIA FOR THE LIQUID \\ METAL PACKAGE LOOPS'HOT CELL FACILITY \\ AND HANDLING SYSTEM \\ AT THE ADVANCED TEST REACTOR
}

Prepared For

U. S. ATOMIC ENERGY COMMISSION

IDAHO OPERATIONS OFFICE

ADVANCED TEST REACTOR

CONTRACT NO. AT(10-1)-1075

March 1963

Approved By:
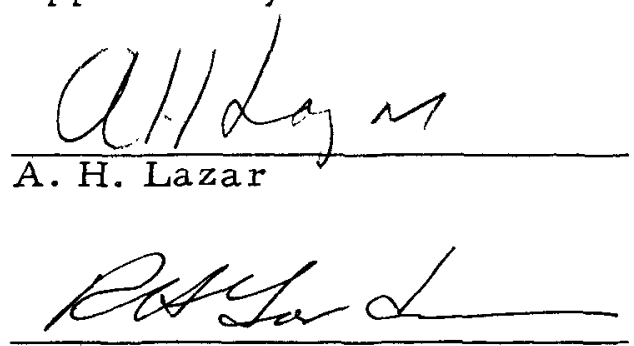

R. H. Gordon
BABCOCK \& WILCOX COMPANY ATOMIC ENERGY DIVISION 1201 KEMPER STREET

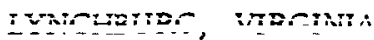

EBASCO SERVICES INCORPORATED

TWO RECTOR STREET

NEW YORK 6, NEW YORK 


\section{PREFACE}

This Design Criteria for the Liquid Metal Loop Facilities associated with the Advanced Test Reactor was prepared by Ebasco Services Incorporated and its nuclear subcontractor th: Babcock \& Wilcox Company, under Contract No. AT (10-1)-1075, administered by the Idaho Operations Office of the United States Atomic Energy Commission.

The Design Criteria for a part of the planned Liquid Metal Loop Facilities was issued in July 1962 in IDO-24041 and the complete results are now presented in IDO-24041, Supplement 1, IDO-24042, and IDO24043. To achieve a cohesive presentation of these interdependent documents the following History, Abstract, and Commentary have been prepared for both Fast and Thermal Flux Loops and the associated Hot Cell Facility. Accordingly, and for reader continuity and clarity, these sections are repeated in each document. 


\section{HISTORY}

A need for facilities in which prototype liquid metal cooled fast and thermal reactor assemblies could be irradiated under conditions of high, fast and thermal neutron fluxes has existed for some time. Heretofore, however, none of the available facilities possessed the requisite characteristics to satisfy these requirements.

The Atomic Energy Commission recognized that the Advanced Test Reactor (ATR) possessed the characteristics for these types of experiments and requested Atomic Power Development Associates, Inc. (APDA) to review the ATR design, the experimental requirements of the liquid metal cooled reactor programs, and the design features and requirements of in-pile package loops for testing these assemblies in the ATR.

APDA reported, APDA-144, that the ATR could be used for the irradiation of typical fast reactor fuel assemblies to high burnups in a fast reactor environment and recommended that the Pratt \& Whitney Aircraft PW-19 loop design be used for this purpose with relatively minor modifications, namely, lengthening the test specimen section and installing a removable bottom closure which would permit the removal and reinsertion of test specimens.

The appropriate fast neutron spectrum would be provided by a boron loaded thermal neutron filter surrounding the test section in conjunction with an extended core to compensate for the large reactivity decrease caused by the filter. APDA's reasons for recommending the adaptation of the PW-19 loop design for this test facility were that they found no major design problems and that the cost of the associated research and development program could be kept to a minimum since the necessary work on the major loop components had already been done by Pratt \& Whitney Aircraft.

APDA also reported, APDA-145, that the ATR could be used as a test facility for sodium cooled thermal reactor fuel assemblies. The basis for this decision was the high thermal neutron flux available in the ATR which would assure adequate heat generation with acceptable flux and power depressions while providing a test section of sufficient size to obtain meaningful data on the hydraulic and thermal characteristics of a small group of fuel elements, in addition to irradiation data on the fuel itself. 
The conceptual design of the thermal flux loop presented by APDA utilized a package loop similar in design to that proposed for the Fast Flux Loop. Sodium was proposed as the primary coolant rather than NaK since it is the coolant that would be used in the reactor systems being tested and because of its better heat transfer capabilities. An additional feature of the APDA design was the control of sodium temperature by varying the effectiveness of the sodium-to-reactor water heat exchanger which, depending on the temperatures required. utilized mercury and/or helium as the heat transfer fluid(s) between the sodium and the reactor water.

Subsequent to the is suance of these two documents, the Atomic Energy Commission asked Ebasco Services Incorporated and its nuclear subcontractor, the Babcock \& Wilcox Company (B\&W) to review these documents. This review indicated that the information presented was not in sufficient detail to permit the initiation of Title I design of these loops.

Therefore, in January 1962, the Atomic Energy Commission requested that Ebasco prepare design criteria for these loops based on utilizing the package concept previously recommended by APDA. However, the use of mercury to vary heat exchanger effectiveness in the thermal flux loop would not be permitted, and another heat transfer scheme was to be devised. In the period between January and October 1962 a detailed effort was made towards establishing satisfactory criteria for these loops. Dur ing this period, many heretofore unrecognized problems of extreme importance were uncovered which indicated the necessity of re-evaluating the package loop concept as applied to the experiment and reactor re quirements.

In October 1962, a meeting was held to discuss the various advantages and disadvantages of the package loop concepts based on the inherent restrictions imposed by the ATR and the requirements of the established design objectives. As a result of this meeting the Atomic Energy Commission directed Ebasco and B\&W to stop work on the development of design criteria based on the package loop concept, to prepare a report summarizing all work completed during the preparation of these design criteria; and to state the reasons for terminating work on the package loop concept. The documents which make up this report are: 


$\begin{array}{ll}\text { IDO-24041 - } & \text { Design Criteria for a Fast Flux Liquid Metal } \\ \text { Loop in the Advanced Test Reactor Is sued } \\ \text { July } 1962 .\end{array}$


The following is a summary of the results of the criteria work performed prior to the termination of work on the package concept, for the liquid metal loop facilities for the Advanced Test Reactor. The purpose of this work was to establish design criteria for the loops and their as sociated facilities which would satisfy the design objectives specified by the Atomic Energy Commission.

The following briefly summarizes, at the time when work was terminated, the conceptual designs and design criteria which had been determined:

1) nuclear criteria for the thermal neutron filter and extended core combination in conjunction with the reference test specimen for the Fast Flux Loop.

2) an appropriate secondary coolant, which in conjunction with the PW-19 loop, would provide the necessary heat exchanger performance capability to satisfy the design objectives for the Fast Flux Loop.

3) pump performance required to satisfy the Fast Flux Loop design objectives when utilizing the PW- 19 loop.

4) physical modifications required to permit the use of the PW-19 loop as the Fast Flux Loop in the $A T R$ and the effects of these modifications on the loop performance capability.

5) Research and Development Program required to confirm and achieve the design criteria established in IDO-24041

6) conceptual design of the thermal loop including the in-core section, sodium-to-helium heat exchanger, helium-to-reactor water heat exchanger, pump motor and associated bearing design requirements, preliminary shielding requirements, control system requirements, and electrical heaters within the permissible space envelope.

7) nuclear criteria for the in-core section in conjunction with the reference thermal flux test specimen which would satisfy the requirements of the design objectives.

8) design criteria for the secondary coolant systems including compressors, heat exchangers, filters, snubbers, purification systems, helium supply system, vacuum system, piping, valving, and control

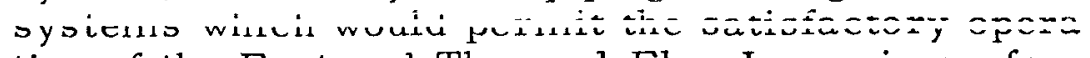
tion of the Fast and Thermal Flux Loops in conformance with the design objectives. 
9) shielding criteria of the secondary systems piping and filters based on the activities of impurities in the helium and residual stainléss steel chips blown out of the system during operation.

10) design criteria for the utilities and structures required for satisfactory operation of the loops.

11) conceptual design of a removable end closure for the loops which would permit remote removal and insertion of fuel elements.

12) conceptual design of top end connections which were satisfactory for remote manipulation.

13) conceptual specimen removal and handling procedures and the associated cooling requirements during these operations.

14) conceptual loop handling procedures for all stages of handling operations and the cooling requirements during these operations.

15) neutron and gamma heat generation rates in the incore tubes which were used in preparation of the loop stress analysis.

16) system performance and hydraulic characteristics in conformance with the design objectives.

17) radiation levels that could be expected from the loops during various handling operations and preliminary loop shielding arrangements.

18) fission gas inventory contained in the loops at the completion of operation for 10,000 hours.

19) conceptual hot cell facility design which would meet the needs of the liquid metal loop program.

20) based on the conceptual design of the hot cell facility a rchitectural, structural, mechanical, electrical, nuclear, and viewing criteria were established.

21) conceptual design with accompanying criteria for the large inert atmosphere hot cell.

22) conceptual design of a specialized liquid metal handling and purification system required to permit $\mathrm{re}-\mathrm{ir}$ radiation of fuel elements and reuse of the Thermal Flux Loop.

23) space required to perform the various fuel element examinations required by the design objectives.

However, as the criteria work progressed it was determined that despite the accomplishments summarized above not all the program requirements could be satisfied. It was also determined that a comprehensive 
and costly research and development program would be necessary to establish basic design and operational information for the loops and their associated equipment and facilities. The need for such a program had not been previously contemplated and, in addition, there was no assurance that the performance of this program would permit the achievement of the loop performance and operating capabilities required by the design objectives.

While no single item can be identified as the major obstacle in the achievement of a satisfactory packaged loop design, evaluation of the many loop design problems - which require solution in such a way as to satisfy the experimenter's design objectives without compromising reactor design or operating philosophy - raised considerable doubt as to the feasibility of this concept. These problems are summarized hereafter. Also, since most of the design problems are common to both the Fast and Thermal Flux Loops, they have not been segregated for each concept.

1) The design and operation of a packaged pump-motor combination to meet the hydraulic performance required within the space limitations appears marginal, particularly for the thermal loop.

2) The objective of a 10,000-hour loop life raised many significant materials problems, the most notable of which were:

a) Design of bearings and selection of lubricants to operate in the liquid metal vapor and high radiation environment.

b) Design of motor winding insulation in conjunction with appropriate shielding to operate in the high radiation environment.

c) Selection of an adequate pressure tube material which would unquestionably perform as required.

3) The design objective of re-usingloops throughout the desired 10,000-hour life raised many questions. The PW-19 loop had not been designed to be re-used, and its use as the Fast Flux Loop precluded meeting this design objective. While the Thermal Flux Loop is a new design, the feasibility of re-using it is questionable since (a) the design of satisfactory loop fill lines which would permit remote manipulation, in the limited space available within the loop envelope, 
had not been achieved, (b) the effectiveness and operability of the external sodium purification system had not been demonstrated and (c) the practicability of remotely machining and welding of materials that had been subjected to varying periods and intensities of radiation, elevated temperatures and liquid metal environment had not been established.

4) The design objectives required the adaptation of PW-19 loop io satisfy the requirements of the Fast Flux Loop. Many of the design changes required to enable its installation in ATR would be of such a nature as to question the practicality of such adaption. The most significant changes would be :

a) Modification of the heat exchanger to permit refueling of the ATR without moving the loop.

b) Modification of the helium return tubes to permit refueling the ATR without moving the loop.

c) Modification of the liquid metal and helium fill lines to permit installation of previously irradiated fuel specimens in a new loop within the hot cell facility

5) Since the ATR core has regions which exhibit positive void coefficients of reactivity, a loop rupture would result in an increase of reactivity. Therefore, it is deemed necessary to either double contain the in-reactor portion of the loop high pressure (greater than reactor operating pressure) helium secondary coolant system or reduce the helium pressure below that of the reactor water. It is doubtful, because of the fixed design of the PW-19 loop, that the Fast Flux Loop could be double contained and still attain the other design objectives. Use of secondary coolant at a reduced pressure would decrease the maximum achievable specimen fission power below the design objective of $150 \mathrm{kw}$. For the thermal loop, even with the greater design latitude, the feasibility of double containment while still meeting all the design objectives is also doubtful.

6) The design objective of re-irradiation of test specimens is considered marginal since (a) the procedures required to assure adequate cooling during specimen removal, examination and re-insertion are complicated and hazardous, (b) the feasibility of simultaneously heating the loop to 250 F-400 F to fill with sodium while cooling the test section to

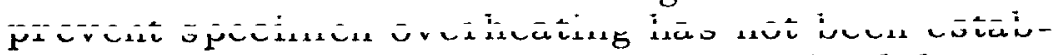
lished, (c) the absolute minimum required decay 
periods of four weeks for a fast test specimen and 27 weeks for a thermal test specimen before they can be re-inserted (even with forced cooling) results in a long and expensive program to achieve 10,000 hours of irradiation, and (d) the high radiation levels from the loop would require remote handling procedures within the reactor vessel as well as the hot cell which further complicates the vertical handling of the 16-foot long, 1,000-pound loop.

7) While the filter and extended core appeared feasible to satisfy the physics requirements of the Fast Flux Loop, the high heat generation rates induced in the filter by the attenuation of thermal neutrons caused excessive mechanical and thermal stresses in the conceptual design of the filter and loop pressure tube. In addition, the replacement of these components at 2,000- and 800-hour intervals respectively, as a result of boron and uranium burnup was unacceptable to the operator since the additional loop handling would be time consuming and potentially injurious to the specimen and/or loop.

8) While there appear to be no unsolvable problems associated with the hot cell facility design,-specimen handling requires either auxiliary forced gas cooling or decay periods far in excess of the minimums stated in 6 (c) above. Forced cooling complicates remote handling and entails the risk of specimen failure should cooling be lost.

9) The design objective of examining niobium clad specimens in the hot cell facility does not appear feasible since it is doubtful that the highly pure inert gas atmosphere required could be maintained in such a large hot cell. 
Based on the results of the criteria studies it was concluded that achievement of the design objectives could not be predicted with any high degree of confidence when utilizing the package loop concept based on the design philosophy of the PW-19 loop. Therefore, it was recommended to the Atomic Energy Commission that the bottom reentrant loop concept be investigated since it appeared to be a more practical and feasible means of fulfilling the design objectives. How ever, the AEC terminated re-entrant loop study work before any substantial effort was expended and ultimately elected to suspend any furthe $r$ consideration of the liquid metal loops in the ATR.

If interest in the liquid metal reactor fuel testing program is revived, satisfactory designs may be achieved by (a) utilization of other package loop concepts, (b) appropriate modification of the design objectives while utilizing the PW-19 loop concept, or (c) utilization of another test reactor while utilizing the PW-19 loop or other package loop concepts. Additional work would be required to establish feasibility of these or other schemes. 


\section{ACKNOWLEDGMENT}

Ebasco Services Incorporated and the Babcock \& Wilcox Company acknowledge the assistance rendered by the following individuals and organizations in preparing the design criteria and reviewing this document.

\section{United Nuclear Corporation}

L. Berkowitz

D. M. Rosh

Phillips Petroleum Company

L. H. Jones

\section{Atomic Energy Commission}

J. C. McKinley, IDO

R. Silver, COO

E. Sowa, ANL-COO 
PART I - SUMMARY REPORT OF DESIGN CRITERIA FOR THE LIQUID METAL PACKAGE LOOPS' HOT CELL FACILITY AT THE ADVANCED TEST REACTOR

$\underline{\text { Page }}$

1. INTRODUCTION . . . . . . . . . . . . . . . . 1

2. PURPOSE . . . . . . . . . . . . . . . . . . 2

3. GENERAL FACILITY DESCRIPTION

3.1 Objective

3.2 Site

3.3 Location

3.4 Building

4. FACILITY SERVICES

4.1 General

4.2 Electrical

4.3 Steam

4.4 Compressed Air.

4.5 Sanitary Sewage.

4.6 Waste Disposal

4.6.1 Hot Waste

4.6.2 Warm Waste.

4.6.3 Gaseous Waste

4.7 Communications

4.8 Water

4.9 Canal Vacuum Cleaning System

5. BUILDING DESCRIPTION

5.1 General

5.2 Structural

5.3 Architectural

5.4 Mechanical

5.4.1 Containment .

5.4.2 Heating and Ventilation

5.4.3 Fire Prevention and Protection Systems . . . 10

5.4.4 Compressed Air . . . . . . . . . . . 11

5.4.5 Plumbing. . . . . . . . . . . . . . 11

5.4.6 Sanitary Facilities . . . . . . . . . . 11

5.4.7 Hot Water System . . . . . . . . . . . 12

5.5 Communications

5.5.1 Telephone . . . . . . . . . . . . 12

5.5.2 Evacuation Alarm . . . . . . . . . . . 12

5.5.3 Intercom System . . . . . . . . . . 12

5.5.4 Paging . . . . . . . . . . . . . . 13

5.6 Radiation Monitoring . . . . . . . . . . . . 13

5.7 Electrical . . . . . . . . . . . . . . . 13

5.8 Emergency Shower. . . . . . . . . . . . . 16

5.9 Lighting . . . . . . . . . . . . . . . . 16 
6. HOT CELL

6.1 General . . . . . . . . . . . . . . 17

6.2 Cell Interior

6.2.1 General . . . . . . . . . . . 19

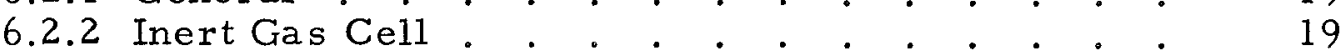

6.2.3 Air Cell . . . . . . . . . . . . . . . . . 20

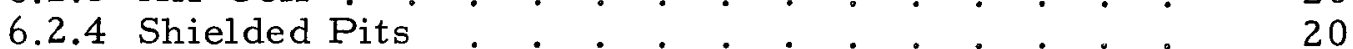

6.3 Shielding . . . . . . . . . . . . . . . 20

6.4 Viewing

6.4.1 Shielded Windows. . . . . . . . . . . 21

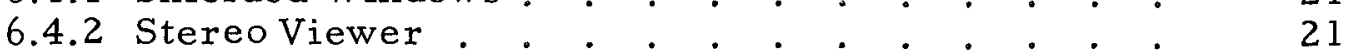

6.4.3 Remote Periscope . . . . . . . . . . 22

6.5 Manipulators

6.5.1 Master Slave . . . . . . . . . . . . 22

6.5.2 Electromechanical . . . . . . . . . 22

6.6 Cranes . . . . . . . . . . . . . . . . 23

6.7 Penetrations

6.7.1 General . . . . . . . . . . . . . . 23

6.7.2 Access Door . . . . . . . . . . . . 24

6.7.3 Transfer Drawer . . . . . . . . . . . 24

6.7.4 Transfer Lock. . . . . . . . . . . . 25

6.7.5 Roof Penetrations. . . . . . . . . . . 25

6.7.6 Drop Tubes . . . . . . . . . . . . . 25

6.7.7 Spare Penetrations . . . . . . . . . . 25

6.7 .8 Viewing Equipment . . . . . . . . . . 25

6.7.9 Systems and Utilities . . . . . . . . . 26

6.8 Shielded Pits

6.8.1 Air Cell . . . . . . . . . . . . . . 26

6.8.2 Inert Gas Cell . . . . . . . . . . . . 27

6.9 Special Systems
6.9 .1 Electrical . . . . . . . . . . . 27

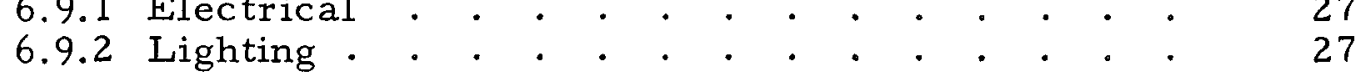

6.9.3 Pneumatic . . . . . . . . . . . . . 28

6.9.4 Vacuum Cleaner . . . . . . . . . . . 29

6.9 .5 Vacuum . . . . . . . . . . . . . . 29

6.10 Ventilation System

6.10 .1 Air Cell . . . . . . . . . . . . 29

6.10.2 Inert Gas Cell . . . . . . . . . . . 29

6.11 Liquid Metal Systems . . . . . . . . . . . 30

7. WARM AREA

7.1 General . . . . . . . . . . . . . . . . 31

7.2 Elevation 101 Feet
7.2.1 Hot Cell Access Area . . . . . . . . . 32

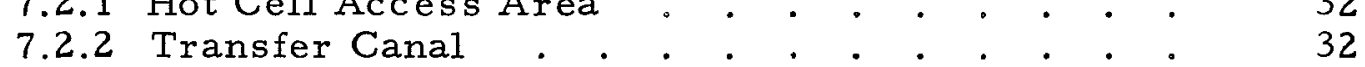

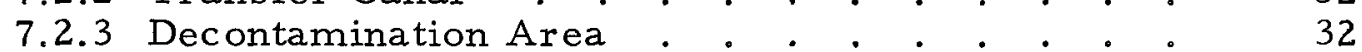

7.2.4 Warm Change Room . . . . . . . . . . 33

7.3 Elevation 87 Feet

7.3.1 Ventilation Area . . . . . . . . . . . 33

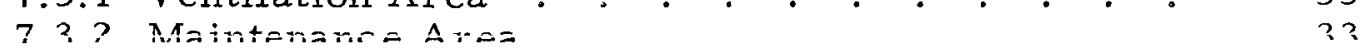

7.4 Elevation 79 Feet . . . . . . . . . . . . 34 
8. CLEAN AREA

8.1 General . . . . . . . . . . . . . . . 35

8.2 Controlled Clean Area . . . . . . . . . . . 35

8.3 Loop and Liquid Metal Handling Area . . . . . . 35

8.4 Cold Change Room . . . . . . . . . . . . . 36

8.5 Darkroom. . . . . . . . . . . . . . . . 36

9. LOOP HANDLING

9.1 General . . . . . . . . . . . . . . . . 37

9.1.1 Loop Design . . . . . . . . . . . . . 38

9.1.2 Decay Time and Loop Turn-Around . . . . . 39

9.2 Loop Transfer

9.2.1 Hot Cell-Canal Transfer . . . . . . . . . 40

9.2.2 Inter-Cell Transfer . . . . . . . . . . 41

9.3 Replacement of Thermal Neutron Filter . . . . . . 41

9.4 Specimen Removal
9.4 .1 General . . . . . . . . . . . . . 41

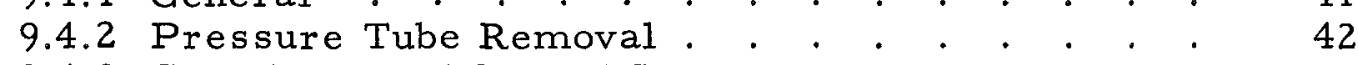

9.4 .3 Containment Tube and Specimen
Removal . . . . . . . . . . 42

Specimen Insertion
9.5 .1 General . . . . . . . . . . . . 43

9.5.2 Non-Irradiated Loops and Specimens. . . . . 44

9.5.3 Irradiated Specimens - New Loops . . . . . 44

9.5.4 Irradiated Specimens - Irradiated Loop . . . . . 44

9.5.5 New Specimen - Irradiated Loop . . . . . . 45

9.6 Sub-Cell Transfer Cask . . . . . . . . . . . 45

9.7 Research and Development
9.7 .1 General . . . . . . . . . . . . . . . . 46

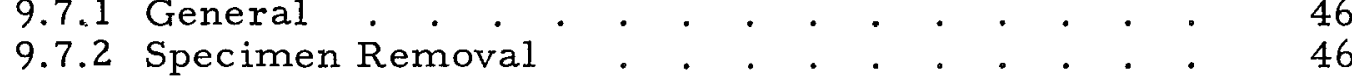

9.7.3 Specimen Insertion . . . . . . . . . . . . . 46

9.7.4 Thermal Flux Loop . . . . . . . . . . 47

10. SPECIMEN HANDLING

10.1 General . . . . . . . . . . . . . . . . 49

10.2 Specimen Description . . . . . . . . . . . . 49

10.3 Inspection Requirements . . . . . . . . . . . 49

10.4 Specimen Cooling . . . . . . . . . . . . . 50

10.5 Specimen Design . . . . . . . . . . . . . 51

10.6 Specimen Cleaning . . . . . . . . . . . . . . . 51

REFERENCES . . . . . . . . . . . . . . . . . . 53

FIGURES 1 to 20
$55-74$ 
PART II - SUMMARY REPORT OF DESIGN CRITERIA FOR THE LIQUID METAL PACKAGE LOOPS' HANDLING SYSTEM AT THE ADVANCED TEST REACTOR

$\underline{\text { Page }}$

1. INTRODUCTION . . . . . . . . . . . . . . . . . . 77

2. PURPOSE . . . . . . . . . . . . . . . 78

3. FACILITY DESCRIPTION

3.1 Reactor. . . . . . . . . . . . . . . . . 79

3.2 Loop . . . . . . . . . . . . . . . . . . . . .

3.3 Loop Location . . . . . . . . . . . . . . . 80

4. RADIATION LEVELS

4.1 General . . . . . . . . . . . . . 81

4.2 Fast Flux Loop . . . . . . . . . . . . . . . .

4.3 Thermal Flux Loop . . . . . . . . . . . . . 84

5. REACTOR CRITERIA

5.1 General . . . . . . . . . . . . . . . 86

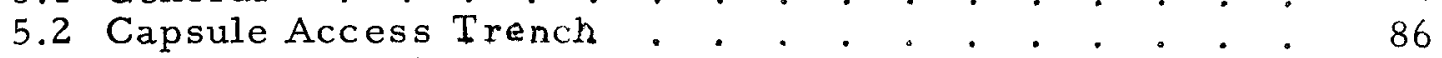

5.3 Reactor Vessel Entry . . . . . . . . . . . . 86

6. LOOP HANDLING

6.1 General . . . . . . . . . . . . . . . 88

6.2 Loop Removal . . . . . . . . . . . . . . 88

6.3 Loop Insertion . . . . . . . . . . . . . . . . . . . . 91

6.4 Canal Transfer . . . . . . . . . . . . . . . 91

7. REPLACEMENT OF EXTENDED CORE
AND HAFNIUM FILTER . . . . . . . . . . . . . . . . . 92

8. RESEARCH AND DEVELOPMENT . . . . . . . . . 93

REFERENCES . . . . . . . . . . . . . . . . 95

$\begin{array}{ll}\text { FIGURES } 21 \text { to } 29 & 97-108\end{array}$ 
PART I

Page

A - Program Design Objectives $\quad$ lll

B - Hot Cell Facility 137

C - Hot Cell Facility Liquid Metal Systems 151

D - Hot Cell Facility Inert Atmosphere Systems 165

E - Fast Flux Liquid Metal Package Loop Decay Periods for Loop Handling

F - Thermal Flux Liquid Metal Package Loop Decay Periods for Loop Handling

G - Loop Handling Procedures

H - Fast Flux Liquid Metal Package Loop Thermal Analysis for Specimen Handling

I - Thermal Flux Liquid Metal Package Loop Thermal Analysis for Specimen Handling

J - Hot Cell Shielding Requirements for Package Loop Handling Operations and Storage

PART II

K - Fast Flux Liquid Metal Package Loop Radiation Dose Rates

L - Thermal Loop Shielding Analysis

M - Preliminary Fast Flux Package Loop Handling Study

N - Package Loops Fission Products Gas Inventory 
PART I

1 Gastight Building Penetrations . . . . . . . 8

2 Radiation Detection System . . . . . . . 14

3 Estimated Electrical Requirements for the Hot Cell Facility . . . . . . . . . . . 15

4 In-Cell Loop Handling Requirements . • • . 17

5 In-Cell Specimen Examination . . . . . . . 18

6 Hot Cell Facility Warm Areas . . . . . . 31

7 Hot Cell Facility Clean Areas . . . . . . . 35

8 Hot Cell Loop Handling Operations . . . . . . 37

9 Decay Periods for Fast Flux Loop Handling . . . 39

10 Decay Periods for Thermal Flux Loop Handling • . 40

11 Reference Specimen Dimensions . . • . . . 49

12 Test Specimen Inspection Requirements . . . . 50

PART II

13 ATR Shield Design Dose Rate Criteria • . . . 82

14 Water Thicknesses Above the Top of the
Fast Flux Loop. . . . . . . . . . . 83

15 Water Thicknesses Above the Top of the
Thermal Flux Loop . . . . . . . . . . 84

16 Thermal Flux Loop Radiation Levels . . . . . 85

17 Water Surface Radiation Levels From the
Thermal Flux Loop . . . . . . . . 87

18 Fast Flux Loop Decay Periods . . . . . . . 89

19 Thermal Flux Loop Decay Periods . . . . . 90 


\section{FIGURES}

PART I

1 ATR-MTR-ETR Plot Plan

2 Hot Cell Facility

3 Plan and Sections

$4 \quad$ Hot Cell Facility Ventilation System

5 Hot Cell Facility Radiation Detection Locations

6 Hot Cell Facility Lighting

$7 \quad$ ATR Hot Cell Facility Fission Product Dose Rate Vs. Magnetite Concrete Thickness

8 Conceptual Hot Cell Penetrations

10 Suggested Top End Arrangement for the Thermal Flux Loop

11 Thermal Flux Loop In-Core Section

12 Containment Tube End Closure

13 Fast Flux Specimen Removal Concept

14 Liquid Metal Package Loops Helium Coolant Casing

15 Fast Flux Reference Test Specimen

16 Thermal Flux Reference Test Specimen

17 Fast Flux Specimen - Rate of Specimen Temperature Rise

18 Thermal Flux Specimen - Rate of Specimen Temperature Rise

19 Specimen Cooling Helium Adapter

20 Specimen Cooling Helium Manifold

21 Installation of the Package Loops in the Advanced Test Reactor

22 Advanced Test Reactor Core

23 ATR Fast Flux Loop After Shutdown Dose Rates Vs. Thickness of Water Over In-Core Portion of Loop

24 ATR Fast Flux Loop After Shutdown Dose Rates Vs. Thickness of Water Over In-Core Portion of Loop

25A Fast Flux Liquid Metal Package Loop Removal Scheme 2 Sheet 1 of 3

B Sheet 2 of 3

C Sheet 3 of 3

26 Fast Flux Liquid Metal Package Loop - Loop Transfer Tool

$27 \mathrm{~A}$ Fast Flux Liquid Metal Package Loop Installation Scheme 2 Sheet 1 of 2

B Sheet 2 of 2

20 Fast Flux Tiguid Motal Package Loon Hot Cell Transfer Cart 
PART I

SUMMARY REPORT OF DESIGN CRITERIA FOR THE LIQUID METAL PACKAGE LOOPS HOT CELL FACILITY AT THE ADVANCED TEST REACTOR 


\section{INTRODUCTION}

An important aspect of the Advanced Test Reactor Liquid Metal Package Loop Program will be the ability to perform on-site inspections of irradiated fuel specimens.

As part of the conceptual study of the Liquid Metal Loop Program, undertaken by Atomic Power Development Associates (APDA) in 1961, an investigation was made of existing hot cell facilities at the National Reactor Testing Station.

The results of their study as reported in APDA-144 and 145 (Refer ences 1 and 2 ) were the finding that the existing facilities were not suitable for loop handling because of height limitations, shielding, openings and atmosphere control, and that the need for a new hot cell facility existed.

Consequently, Ebasco Services Incorporated and its nuclear subcontractor, the Babcock \& Wilcox Company, have prepared criteria for Titles I and I design of the hot cell facility as part of the ATR Liquid Metal Package Loop Program. This work, started in January 1962, has drawn upon AEC design objectives (Reference 6), the APDA conceptual design studies (References land 2), and the design of existing hot cell facilities and experience operating personnel.

The authors of this document have attempted to make it as complete as possible, but the complex requirements of the program leave areas where new and highly specialized techniques will have to be developed. These areas, which will require detailed studies during Title I and research and development effort, are pointed out and solutions indicated wherever possible.

The design of a large, high-level, alpha-gamma cell with complete containment of particulate matter is a relatively new field requiring many unorthodox and untried approaches. While some hot cells of this type are being built, none have as yet been operated. Attention is called to two facilities which are nearing completion and which may prove to be of assistance in the design of the Liquid Metal Loop hot cell. These facilities are the High Radiation Level Examination Laboratory (HRLEL) at Oak Ridge National Laboratory, and the EBR-II Fuel Cycle Facility (FCF) at the National Reactor Testing Station. 


\section{PURPOSE}

The purpose of this document is to present criteria for the Titles I and I design of the hot cell facility for the Advanced Test Reactor

Liquid Metal Package Loop Program. 


\section{GENERAL FACILITY DESCRIPTION}

The hot cell facility will be an independent structure specifically designed to handle ATR Fast and Thermal Flux Loops and test specimens.

The facility has been designed to provide for complete handling and maintenance of the Liquid Metal Package Loops prior to and after irradiation. The facility will contain space for initial loop preparation, a hot laboratory for post-irradiation specimen removal and inspection, plus sufficient space for supporting equipment and personnel.

\subsection{Objective}

The primary purpose of the hot cell facility is to provide the means of determining the results of irradiation experiments using the Liquid Metal Package Loops. To meet this objective the hot cell facility will require the capability of handling irradiated Fast and Thermal Flux Loops and test specimens in accordance with the design objectives given in Design Data Sheet M-6001 "Liquid Metal Loop Facilities Program Design Objectives," which is included in this document as Appendix A.

\subsection{Site}

The hot cell facility site is located adjacent to the west end of the Advanced Test Reactor building in the ATR-MTR-ETR site at the National Reactor Testing Station, as shown in Figure 1. A complete description of the ATR site is given in report IDO-24040 (Reference 3).

\subsection{Location}

The location of the hot cell facility was fixed by USAEC-IDO direc tives requiring that the facility be located outside of the ATR building (Reference 4), that the loop is to be transferred from the reactor to the hot cell through the canal (Reference 5) and that provisions for extending the canal be incorporated at the west end of the storage canal and ATR building (Reference 5).

The area in which the hot cell facility must be located (Figure 2), because of the above requirements, is 100 feet long by $40-1 / 2$ feet wide and straddled on the north and south by truck access roads. The access roads, as presently designed, are 20 feet wide and pass into the ATR building through 14 foot and 12 foot wide truck doors respectively.

In order to provide sufficient space for the hot cell facility, the roadway gutters adjacent to the facility will have to be removed and the roads pitched to carry runoff to the gutters along the outer edge.

\subsection{Building}

The hot cell facility shown in Figure 3 will be a gastight structure (leak rate to be determined during Title I) approximately 80 feet long by 48 feet wide. The building height will be 32 feet above grade (to elevation 129) and extend below grade tor 18 teet (to elevation 19 ). Ine iuricing 
will contain two shielded hot cells, one with an air environment (air cell) and one with an inert gas atmosphere (inert gas cell), and warm and cold working areas plus all equipment required for operation of the facility.

To minimize the duplication of equipment and facilities, ATR services and utilities have been used wherever possible. The interconnec tions between the two buildings being utility and service lines, radioactive liquid waste lines and the transfer canal. The separation between the ATR and the hot cell facility will be maintained by having the wall between them extend into the canal below the water level.

The hot cell facility has been divided into four areas based on the expected radiation levels to be encountered during normal operation.

These areas listed in the order of decreasing radiation levels are:

Zone $\mathrm{A}$ : Hot cell for handling highly radioactive $(\alpha, \beta, \gamma)$ material.

Zone B:: Warm working areas for handling low level radiation.

Zone C: Controlled clean area which will have a radiation background level higher than normal background, but no higher than $0.25 \mathrm{mr} / \mathrm{hr}$.

Zone D: Clean area having only a normal background level. 


\section{FACILITY SERVICES}

\subsection{General}

All services required for the operation of the hot cell facility shall be obtained from the ATR building distribution systems.

The services to be provided are:

Electrical Power

Steam

Compressed Air

Sanitary Sewage

Waste Disposal

Communications

Water

Canal Vacuum Cleaning

The sizes of the systems shall be determined during Title I design.

\subsection{Electrical}

Power for the facility shall be obtained from the ATR electrical distribution system. The power shall be supplied from the 480 -volt, 3-phase, 60-cycle commercial and diesel-commercial control centers.

\subsection{Steam}

Steam at 135 psig shall be supplied from the existing ATR-MTRETR two-pipe steam system. Condensate from the hot cell facility shall be returned to the ATR condensate pump.

\subsection{Compressed Air}

The hot cell facility shall be supplied from ATR-MTR-ETR compressed air system with plant air at 150 psig and instrument air at 115 psig.

\subsection{Sanitary Sewage}

The sanitary waste system in the ATR facility shall be used as the receiver for the hot cell facility sanitary waste.

\subsection{Waste Disposal}

\subsubsection{Hot Waste}

The hot experimental waste from the hot cell facility shall be piped to the 1,000-gallon hot experimental waste storage tank located below the AIK seconi vabenient. 


\subsubsection{Warm Waste}

The warm experimental waste from the hot cell facility shall be piped to the 5,000-gallon warm waste tank located below the ATR second basement.

\subsubsection{Gaseous Waste}

Gaseous waste from the hot cell facility shall be discharged into the ATR stack.

\subsection{Communications}

Communications to be supplied from the ATR consist of:

1) Telephone

2) Paging System

3) Evacuation Alarm

4) Fire Alarm

These systems are described in IDO-24040 (Reference 3).

\subsection{Water}

The hot cell facility shall be supplied with the following water systems:

1) Potable Water

2) Fire Water

3) Well Water

These systems are described in IDO -24040 (Reference 3).

\subsection{Canal Vacuum Cleaning System}

The ATR canal vacuum cleaning system shall be extended into the hot cell facility for maintenance of the transfer canal within the facility. 


\section{BUILDING DESCRIPTION}

\subsection{General}

As described in Section 3.4 and shown in Figure 3 the hot cell facility will be an enclosed gastight area (leak rate to be determined during Title I) of approximately 5,500 square feet, containing four working levels.

Access to the first floor from the outside is provided on the west side of the building, with additional loading and unloading access provided on the north side.

Access to the upper level will be provided by a main stair well located in a clean area while access to the lower level will be through a stair well in a controlled limited access area.

The ATR transfer canal will extend into the east side of the hot cell facility, through a warm area, terminating under the air cell. The supporting areas consisting of offices, maintenance and control areas have been located, as shown on Figure 3 , to gain maximum utilization and efficiency of space.

\subsection{Structural}

The hot cell facility design shall conform with the requirements as set forth for the ATR complex in the Safety Analysis Report IDO-24040 (Reference 3). )

The hot cell facility substructure shall be of reinforced concrete walls and slab supported on concrete piers which will extend to the lava bed. Where required, all masonry walls below grade are to be reinforced to resist seismic loads.

The building above grade shall be a gastight (leak rate to be determined during Title I) structure of steel frame construction with exterior walls of non-load-bearing concrete block, or exterior insulated aluminum sandwich panels with interior seal-welded steel plate. The final design is to be determined during Title $I$.

The roof construction shall consist of steel framing with cast-inplace reinforced concrete slab, insulation, and built-up roofing, except for the roof over the hot cells. The latter area, which is of concrete construction shall be waterproofed only. The entire roof area shall be sloped to provide positive drainage into the runoff gutters.

The building shall be designed to conform with the requirements of the applicable building codes including AEC-IDO engineering standards, and shall include provisions for seismic and wind loads. In addition, consideration shall be given to the differential pressure load caused by the operation of the ventilation exhaust blower(s) with the building intake system blocked off. 


\subsection{Architectural}

Interior partition walls, except where radiation shielding is required, shall be constructed of 4 -inch concrete block.

Windows shall be provided in the office areas only, and shall be of the fixed sash type.

The two access doors on the north side of the facility shall be electrically operated vertical-lift type with permanently inflated air seals. A manually operated man door shall be provided in each lift door for emergency personnel exit. The personnel doors shall have a crash bar on the inside surface and an outside emergency operator. The personnel access door in the west wall will be a hollow metal swing type provided with a gastight seal.

All interior structure and finish shall be comparable to the ATR.

\subsection{Mechanical}

\subsubsection{Containment}

The hot cell facility building shall be designed as a gastight structure in accordance with the specifications given in Section 5.2. The integrity of the building shall be maintained by use of gastight penetrations as shown in Table 1.

\section{Table 1}

\section{GASTIGHT BUILDING PENETRATIONS}

a. Systems

1 - Electrical ducts sealed with neoprene plugs for each cable.

2 - Pipes welded to embedded steel plates.

3 - Steam pipes sealed by expansion joints.

4 - Heating and ventilation duct dampers sealed with rubber gaskets.

b. Structural

1 - Masonry walls or sandwich paneling with sealwelded steel liner gasketed and caulked at inter sections with concrete and masonry surfaces.

c. Architectural

1 - Gasketed hollow metal doors with caulked frames.

2 - Caulked windows with fixed sashes.

3 - Gasketed and wedged sliding steel vertical lift doors. 


\subsubsection{Heating and Ventilation}

\subsubsection{General}

The heating and ventilation system for the building, excluding the loop and liquid metal handling area, shall be designed to satisfy the requirements of the various areas based on the parameters of radiation levels, flow patterns, and ventilation practices.

The ventilation system shall contain separate supply and exhaust blowers with associated duct work to insure air flow patterns in the direction of increasing radiation levels. The exhaust air shall be conveyed below grade to the remotely located ATR ventilation stack for discharge to the atmosphere.

The loop and liquid metal handling area shall be independent of the building ventilation system and is described in Section 5.4.2.3.

\subsubsection{Building}

A flow diagram of the heating and ventilation system for the hot cell facility is shown in Figure 4. The system has been designed to supply the building with a maximum of 6,045 $\mathrm{cfm}$ of filtered air.

The system supply equipment will be located in the upper level (elevation 113 feet) heating and ventilation area shown in Figure 3. Air will be drawn into the system through a filter bank and steam heating coils by a two-horsepower centrifugal fan. A second fan identical to the main supply fan has been included for $100 \%$ stand-by capability to ensure a continuous air supply.

The air is supplied primarily to the clean area on the top level of the building with a branch duct to furnish air to the controlled clean area on the main level (elevation 101 feet) and the warm areas at the lower levels.

Part of the air from the upper level will be vented to the atmos phere through the two lavatories. The remaining air will be drawn down to the lower levels by a booster fan, to be used as make-up air for the warm areas as well as to maintain the pressure differential between the clean and warm areas.

The air supplied to the clean areas is drawn through the warm area to maintain a 0.5 inch of water pressure differential between the two. The air drawn through the warm area is then passed into the hot cell (air cell) at a velocity to maintain a pressure differential of 0.5 inch of water between the warm area and the hot cell. The air from the hot cell will then be ducted to the exhaust system.

While the second hot cell will normally be operated with an inert gas atmosphere, the cell will be tied into the building ventilation system in a manner identical to that of the air cell. This secondary atmosphere system will allow for the future operation of the cell with an air environment and wnen ine ceīi nas to de opene a for maintenance and cleanup. A detailed description of the cell ventilation is given in Section 6.10.1. 
The air supplied to the lower level will be ducted to the maintenance and ventilation equipment areas (elevation 87 and $79 \mathrm{feet}$ ) and then exhausted to atmosphere through the ATR stack to maintain a flow pattern in the proper direction.

The exhaust equipment located in the equipment room on the lower level (elevation 87 feet) includes a shielded roughing filter bank, shielded absolute filter bank and two 15-horsepower industrial type centrifugal fans. During normal operation one fan will serve the system with the second fan providing $100 \%$ stand-by. For emergency operation both fans will be operated in parallel to provide twice the flow rate through the hot cells.

\subsubsection{Loop and Liquid Metal Handling Area}

The loop and liquid metal area located on the main level (elevation 101 feet, Figure 3) shall be independent of the building heating and ventilation system. The need for isolating this area is based on preventing the introduction of acrid smoke, from a liquid metal fire, into the building.

The heating and ventilation system for this area will consist of a unit space heater and two roof ventilators. For normal operation one ventilator will provide 30 air changes per hour. For emergency use the second ventilator will double the change rate to 60 per hour.

\subsubsection{Fire Prevention and Protection Systems}

\subsubsection{General}

The fire prevention and protection system shall be designed in accordance with the requirements of the National Board of Fire Underwriters, the National Fire Protection Association Standards, and the USAEC Idaho Operations Office Safety and Fire Protection Design Criteria Manual, IDO-12008.

\subsubsection{Fire Detection}

The automatic fire detection system shall consist of rate compensation thermostatic temperature indicators located on the ceilings of the occupied areas and non-interfering type transmitters, all in accordance with NFPA standards. The fire detectors shall be capable of fire identification without sending in false alarms due to normal changes in ambient temperatures.

\subsubsection{Fire Alarms}

The alarm systems shall be identical to those used within the ATR building, and shall be connected to the existing coded ADT system at the MTR-ETR which sound alarms at the NRTS Central Facilities as well as locally.

\subsubsection{Fire Extinguishers}

Fire extinguishers of the portable $\mathrm{CO}_{2}$ and dry chemical type, complete with wall mounting brackets and hardware shall be installed throughout the occupied areas of the building. 
Portable Met-L-X extinguishers of adequate capacity shall be provided inside (except the hot cell) and immediately outside (except the hot cell) of areas where liquid metal will be present.

Fire hose systems shall be located within the building except for the following areas:

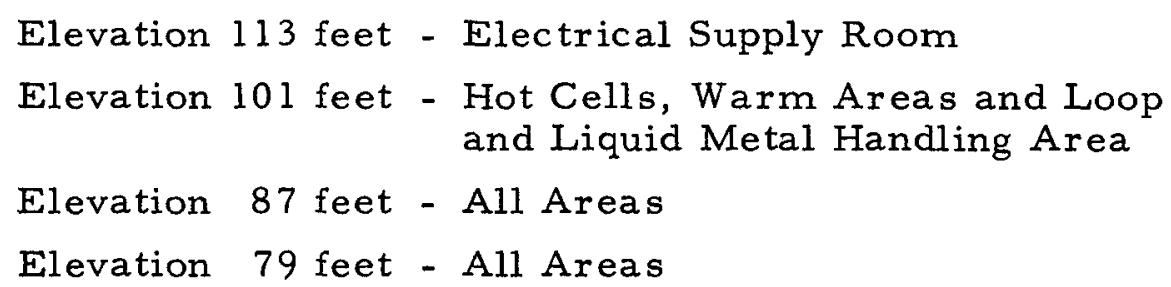

Fire hydrants shall be installed outside of the building within 100 feet of each of the entrances.

\subsubsection{Compressed Air}

\subsubsection{Plant Air}

Compressed air at 150 psig shall be supplied to the following areas:

1 - Elevation 101 feet

a) Loop and Liquid Metal Handling Area

b) Warm Areas

c) Controlled Clean Area

2 - Elevation 87 feet

a) Warm Maintenance Area

3 - Elevation 79 feet

a) Warm Area

b) Helium Recirculation System Area

\subsubsection{Instrument Air}

Compressed air at 115 psig shall be supplied to instruments, actuators and panel boards. Field instruments shall have their own air sets and panel boards shall have dual filters and regulator stations. The areas and amount of air required shall be determined during Title I design.

\subsubsection{Plumbing}

Plumbing and associated piping shall conform to the National Plumbing Code and other local codes and applicable standards as required.

Plumbing for the hot and warm waste systems shall be comparable to that within the ATR.

\subsubsection{Sanitary Facilities}

Discharge from all plumbing fixtures in lavatories, showers, water closets, urinals and from all service sinks, drinking fountains and 
miscellaneous fixtures shall be fed through branch connections to a common building main. The building main shall be gravity fed into the ATR sanitary waste system.

\subsubsection{Hot Water System}

Domestic hot water shall be produced within the hot cell facility. The use of steam or electrical heating shall be determined during Title I.

\subsection{Communications}

\subsubsection{Telephone}

The telephone system shall be an extension of the existing Mountain States telephone system in the ETR-MTR-ATR area. The system shall permit dialing from one extension to another and audible code-calling by dialing a code number.

The system shall also include a special direct telephone connecting the facility supervisor with the ATR supervisor.

\subsubsection{Evacuation Alarm}

The hot cell facility shall have an evacuation alarm system with alarms located to provide complete coverage of the building.

A building alarm signal shall be initiated mechanically by a key in the radiation control office and automatically by the radiation detection equipment described in Section 5.6.

In addition, the alarm system shall be connected to the ATR alarm system and have the capability of sounding all the alarms originating from the latter. Alarms originating in the hot cell facility shall not be sounded in the ATR building.

\subsubsection{Intercom System}

The hot cell facility shall be provided with an intercom system for communications between work areas. The system shall be designed so that contact can be had between any of the stations.

Stations shall be located in the following places:

a) Inside of each hot cell.

b) Outside of each shielding window.

c) All warm areas except the warm change and decontamination rooms.

The use of permanently mounted speaker/microphone units or personnel headphone/microphone sets shall be determined during Title I on a station-by-station basis. 


\subsubsection{Paging}

The hot cell facility shall have an internal paging system providing audible public address throughout the building. The system shall be connected to the ATR paging system for special information and instruc tions.

\subsection{Radiation Monitoring}

The radiation monitoring system shall consist of $\beta, \gamma$ detectors and air monitors located throughout the building to ensure complete sur veillance during normal operation and in the event of an accident.

The location of the detection equipment is shown in Figure 5 and described in Table 2.

The radiation monitoring system shall contain the following features:

1) Equipment shall be identical to that used in the ATR.

2) The electrical power shall be obtained from the automatic throw-over diesel-commercial system in the ATR.

3) Monitors sounding a building-wide alarm shall be tied into the alarm system described in Section 5.5.2.

4) Where applicable, direct radiation and air-borne activity shall be monitored in the same location.

5) The use of additional portable survey equipment shall be determined by administrative control and obtained from the inventory of instruments at the MTR-ETR area.

6) The central radiation monitor panel shall be located in the radiation control office.

\subsection{Electrical}

Electrical power for the hot cell facility shall be distributed throughout the building from load centers located in the electrical supply area at elevation 113 feet. The distribution and control equipment shall be comparable to that used within the ATR.

Table 3 .

A preliminary estimate of the power requirements is given in 
Table 2

\title{
RADIATION DETECTION SYSTEM
}

Alarm System

\begin{tabular}{|c|c|c|c|c|c|c|c|c|c|c|c|c|}
\hline \multirow[b]{2}{*}{$\begin{array}{l}\text { Type and } \\
\text { Function }\end{array}$} & \multicolumn{2}{|c|}{ Instrument Failure } & \multicolumn{2}{|c|}{$\begin{array}{c}\text { Intermediate } \\
\text { Radiation Level } \\
\end{array}$} & \multicolumn{2}{|c|}{$\begin{array}{c}\text { High Radiation } \\
\text { Level }\end{array}$} & \multicolumn{5}{|c|}{ Quantity } & \\
\hline & Indicator & $\begin{array}{l}\text { Audible } \\
\text { Alarm }\end{array}$ & Indicator & $\begin{array}{c}\text { Audible } \\
\text { Alarm }\end{array}$ & Indicator & $\begin{array}{c}\text { Audible } \\
\text { Alarm } \\
\end{array}$ & $\begin{array}{l}\text { Level } \\
79.0^{r} \\
\end{array}$ & $\begin{array}{l}\text { Level } \\
87.0^{r} \\
\end{array}$ & $\begin{array}{c}\text { Level } \\
98^{\prime} \\
\end{array}$ & $\begin{array}{c}\text { Level } \\
101^{1} \\
\end{array}$ & $\begin{array}{c}\text { Level } \\
113^{\prime} \\
\end{array}$ & Total \\
\hline
\end{tabular}

Containment Control Radia tion Monitor

L LP L

L

LP

LPB

2

2

1

\author{
3
}

1 9

Containment Control Continuous Air Monitor

$\mathrm{LP}$

L LP

L

LP

LPB

2

2

1

4

1

10

A Radiation Monitor Station

LP

L LP

L

$\mathrm{P}$

Continuous Air Monitor Mobile

L

L L

L

L

$\mathbf{P}$

$\mathrm{P} \quad \mathrm{P}$

Monitor

L

$\mathrm{P}$

Survey Probe

Hand and Foot

\section{Counter}

Monitor Panel

Portal Monitor

$\begin{array}{lll}L & - & L \\ - & - & - \\ L & - & L\end{array}$

P P

-
L
P

1

L
$L=$ At local detector
$\mathrm{P}=$ At monitor panel
$B=$ Throughout building 


\begin{tabular}{|c|c|c|c|c|c|}
\hline Area or System & Item & $\underline{\text { Size }}$ & $\begin{array}{l}\text { Quan - } \\
\text { tity }\end{array}$ & Voltage & $\begin{array}{c}\text { ATR } \\
\text { Electrical } \\
\text { System } \\
\end{array}$ \\
\hline Facility Heating & Supply Fan & $2 \mathrm{hp}$ & 1 & 440 & Commercial \\
\hline \& Ventilation & Exhaust Fan & $15 \mathrm{hp}$ & $2 \underline{a} /$ & 440 & $\begin{array}{l}\text { Diesel- } \\
\text { Commercial }\end{array}$ \\
\hline \multirow[t]{5}{*}{$\begin{array}{l}\text { Hot Cell Inert } \\
\text { Gas }\end{array}$} & Main Circulating Fan & $5 \mathrm{hp}$ & 2 & 440 & $\begin{array}{l}\text { Diesel- } \\
\text { Commercial }\end{array}$ \\
\hline & $\begin{array}{l}\text { Purification Gas } \\
\text { Booster }\end{array}$ & $5 \mathrm{hp}$ & $2 \underline{b} /$ & 440 & $\begin{array}{l}\text { Diesel- } \\
\text { Commercial }\end{array}$ \\
\hline & Refrigeration System & $5 \mathrm{hp}$ & 2 & 440 & $\begin{array}{l}\text { Diesel- } \\
\quad \text { Commercial }\end{array}$ \\
\hline & $\begin{array}{l}\text { Misc. Blowers and } \\
\text { Pumps }\end{array}$ & $2 \mathrm{hp}$ & 2 & 440 & Commercial \\
\hline & $\begin{array}{l}\text { Misc. Blowers and } \\
\text { Pumps }\end{array}$ & $2 \mathrm{hp}$ & 2 & 440 & $\begin{array}{l}\text { Diesel- } \\
\text { Commercial }\end{array}$ \\
\hline \multirow[t]{8}{*}{ Hot Cell } & Lighting & $6 \mathrm{kw}$ & - & $120 / 208$ & Commercial \\
\hline & Emergency Lighting & $2 \mathrm{kw}$ & - & $120 / 208$ & $\begin{array}{l}\text { Diesel- } \\
\text { Commercial }\end{array}$ \\
\hline & Equipment & $1 \mathrm{hp}$ & 4 & 120 & Commercial \\
\hline & Loop Heaters & $25 \mathrm{kw}$ & - & $120 / 208$ & $\begin{array}{l}\text { Diesel- } \\
\text { Commercial }\end{array}$ \\
\hline & Welder & $13 \mathrm{kva}$ & 1 & 208 & Commercial \\
\hline & Manipulators & $2 \mathrm{kva}$ & 2 & 208 & Commercial \\
\hline & Utility Services & $6 \mathrm{kw}$ & - & 120 & Commercial \\
\hline & Misc. Equipment & $1 \mathrm{hp}$ & 6 & $120 / 208$ & Commercial \\
\hline \multirow[t]{7}{*}{ Building } & Crane & $3 \mathrm{hp}$ & 2 & 440 & Commercial \\
\hline & Lifting Doors & $1-1 / 2 h p$ & 2 & 440 & Commercial \\
\hline & Utility Service & $6 \mathrm{kw}$ & - & $120 / 208$ & Commercial \\
\hline & Lighting & $10-1 / 2 \mathrm{kw}$ & - & $120 / 208$ & $\begin{array}{l}9 \text { kw Com- } \\
\text { mercial } \\
1-1 / 2 \mathrm{kw} \\
\text { Diesel-Com- } \\
\text { mercial }\end{array}$ \\
\hline & $\begin{array}{l}\text { Sub-Cell Transfer } \\
\text { Cask }\end{array}$ & & & & \\
\hline & Misc. Equipment & $1 \mathrm{hp}$ & 8 & $120 / 208$ & Commercial \\
\hline & $\begin{array}{l}\text { Maintenance Area } \\
\text { Equipment }\end{array}$ & $2 \mathrm{hp}$ & 4 & 208 & Commercial \\
\hline Canal & Transfer Mechanism & $2 h p$ & - & 440 & Commercial \\
\hline
\end{tabular}

Notes: a/ One fan for continuous duty, second for stand-by. Both fans to operate simultaneously for emergency conditions.

b/ One gas booster for continuous duty, second for stand-by. 


\subsection{Emergency Showers}

Emergency showers shall be located in all warm areas except those containing liquid metals. The showers shall be located so that they will be closely situated to the emergency egress traffic pattern.

\subsection{Lighting}

The building lighting system (approximately 10-1/2 kw) shall be furnished as shown in Figure 6. All lighting shall be arranged for alternate circuitry, that is, alternate lights or rows of lights shall be placed on alternate circuits so that the loss of one circuit shall never place a room in complete darkness.

At least $10 \%$ of the lighting in each area shall be on the ATR dieselcommercial bus. 


\section{HOT CELL}

\subsection{General}

The shielded area for handling irradiated loops and specimens (Zone A) is a rectangular structure of high density concrete containing 224 square feet of floor area. The structure has been divided into two cells each 8 feet deep by 25 feet high. The first cell will be 12 feet long and have a once-through air atmosphere while the second cell will be 18 feet long and have a recirculating inert gas atmosphere with provisions for use with a once-through air atmosphere.

The sizes of the hot cells have been based on the work to be per formed for the complete handling of fast and thermal flux loops and specimens. A detailed list of operations to be performed in each cell is given in Tables 4 and 5 .

Table 4

\section{IN-CELL LOOP HANDLING REQUIREMENTS}

I Cell Number 1 (Air)

1 - Transfer loop into hot cell from canal and from the hot cell into the canal.

2 - Dry the loop.

3 - Remove radioactive contamination (alpha, beta and gamma) from the outside of a loop prior to re-irradiation.

4 - Inspect irradiated specimens as listed in Table 5 .

II Cell Number 2 (Inert Gas)

1 - Remove and replace thermal neutron filters.

2 - Remove irradiated test bundle from the loop.

a) Open loop.

b) Drain liquid metal from the loop.

c) Remove the test bundle from the loop without exceeding the maximum allowable surface temperature and without mechanical damage to the test bundle or the loop.

3 - Transfer the test bundle to a storage container.

4 - Transfer the loop to a storage rack or pit.

5 - Specimen Handling.

a) Remove liquid metal from the test bundle.

b) Remove the test bundle from the Flow Control Shroud.

c) Puncture and reweld individual fuel pins. (Fission aas collection See Table 5.

d) Reassemble the test bundle. 
6 - Insert irradiated test bundle in a loop.

a) Reinsert the test specimen in the loop without exceeding the maximum allowable surface temperature and without mechanical damage to the test bundle or the loop.

b) Close and seal the loop.

c) Fill the loop with clean liquid metal.

d) Purify the liquid metal (thermal loop only).

e) Pressurize the liquid metal cover gas and establish the various helium atmospheres.

f) Close and seal all fill lines.

7 - Test reassembled loop.

a) Inspect for weld integrity.

b) Operational check of motor, pump, heat exchanger and loop instrumentation.

8 - Additional space to:

a) Store four loops.

b) Store two fast loop fueled specimens and two the rmal loop fueled specimens at the same time.

c) Handle loop in a manner to preclude damage to internal components by liquid metal coolant.

d) Store liquid metal waste.

e) Load irradiated test specimens into shipping casks.

Table 5

IN-CELL * SPECIMEN EXAMINATION

A - TEST BUNDLE

1 - Macro and visual inspection (up to $30 \mathrm{x}$ ).

2 - Macro photography.

3 - Measurement of fuel spacing.

B - INDIVIDUAL TEST ELEMENTS

1 - Macro and visual inspection (up to 30x).

2 - Macro photography.

3 - External dimension measurements.

4 - Density and/or weight.

5 - Gamma scan for relative activity and fuel redistribution.

6 - Electrical resistivity.

7 - Leak detection.

8 - Nondestructive measurement of meat. 
9 - Fission gas collection and reseal of tubes. (Cell No. 2)

10 - Eddy current test for bond.

11 . Ultrasonic testing.

* All operations are to be done in the air cell except as noted. The ex amination within an air cell is based on the following assumptions:

1 - Only stainless steel clad specimens will be examined.

2 - A failed fuel element will not be re-irradiated and can be returned to the experimenter for examination at his own facility.

The hot cells have been sized to provide sufficient working space to accomplish the operations listed. However, a detailed Title I study will be required to verify this. The need for further study is required by:

a) the specialized nature of the loop handling equipment (which will have to be designed),

b) the fact that only a conceptual design of the Thermal Flux Loop is available at this time, and

c) the inspection equipment will not be supplied by the Architect -Engineer (Reference 6).

The hot cell shall be designed to withstand blast loads imposed by the maximum credible accident. Blast loads, overpressure, pulse duration, and decay rates are to be determined during Title $\mathbb{I}$ study. The hazards associated with the handling of plutonium (up to 450 grams in the Fast Flux Loop) will require that the hot cell be capable of the complete containment of alpha-emitting particulate matter as well as shielding personnel against gamma radiation.

\subsection{Cell Interior}

\subsubsection{General}

The floor of the hot cell has been established at elevation $101^{\prime}-4^{\prime \prime}$ based on the height of the transfer canal. The floor shall be pitched for positive drainage to the warm waste drains.

Brackets shall be attached to the walls to support loops (in a vertical position), equipment and storage racks and shelves. The quantity and location of the brackets shall be determined by the design and placement of the loop handling equipment.

Any in-cell equipment located beyond the reach of the cell manipulators shall have remote control actuation as the primary means of operation with a backup mechanical control designed for and within reach of the manipulators.

\subsubsection{Inert Gas Cell}

The interior concrete surfaces of the inert gas cell shall be lined with stainless steel plate or stainless clad carbon steel. The minimum thickness of the wall and ceiling plates shall be 1/4 inch, while the floor shall

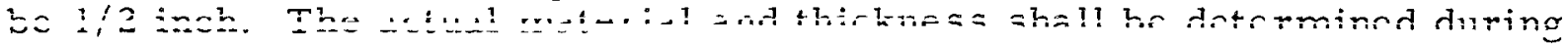
Title I study taking into consideration material costs, structural strength and method of construction. 
The liner shall form a leaktight structure with all joints being welded and ground smooth. The liner shall be tied into the concrete wherever needed for structural purposes and to prevent bowing and as support for the brackets described in Section 6.2.1. The integrity of the liner shall be determined by use of the most reliable leak testing method consistent with field fabrication techniques.

\section{2 .3 Air Cell}

The interior concrete surfaces of the air cell shall be lined in a manner similar to the inert atmosphere cell to a height of 11 feet. The top of the lining shall be sealed to the concrete.

Exposed concrete surfaces shall have a dense smooth finish free of holes, porosity and irregularities. The concrete surfaces shall be coated with a phenolic base radiation resistant paint chemically ine rt to aqueous deconta minants.

\subsubsection{Shielded Pits}

The hot cells shall contain a total of six shielded pits for loop handling and storage as described in Section 6.8 .

\subsection{Shielding}

The hot cell shielding shall be designed on the basis of a maximum dose rate of $0.25 \mathrm{mrem} / \mathrm{hr}$ at the external surfaces. Thicknesses of the floor and lower part of the walls have been tentatively set at $4-1 / 2$ feet of high density concrete. As shown in Figure 7, a thickness of $4-1 / 2$ feet of $3.55 \mathrm{~g} / \mathrm{cc}\left(22 \mathrm{lb} / \mathrm{ft}^{3}\right)$ density concrete will provide sufficient shielding for two fast flux and two thermal flux loops approximately 12 hours after shutdown. The final wall thickness and concrete density shall be determined during Title I study. Particular attention should be given to $215 \mathrm{lb} / \mathrm{ft}^{3}$ Barite concrete. The aggregate for this type of concrete is available locally at the NRTS, and its use may be advantageous from an economic standpoint.

The roof slab and upper sections of the walls will not require as much shielding as the lower sections. The reduced shielding can be obtained by use of thinner sections of the high-density concrete or by maintaining approximately the same wall thicknesses throughout (allowing for equipment setbacks) with a lower density concrete. The method and sizing of the re duced shielding shall be determined during Title I study.

The wall between the two cells shall be approximately 2 feet of high density concrete to allow entry into either cell without complete decontamination of the other cell.

The inside of the shielding walls shall have setbacks at approximately 12 and 22 feet above the floor. The upper setback shall be utilized as support for the in-cell crane. The lower setback shall be utilized as support for the electromechanical manipulator. The exact location of the setbacks shall be determined during Title $I$ and shall be consistent with the requirements for the equipment described in Sections 6.5 and 6.6. 
The inert gas cell shall be a gastight structure with a total uncontrolled in-leakage, through all shielding penetrations, not exceeding $1 \mathrm{cfh}$. The air cell shall be designed for minimum in-leakage.

Penetrations of the shielding wall will be required for equipment, utilities and access into the cells. The design criteria for these penetrations are presented in Section 6.7.

\subsection{Viewing}

\subsubsection{Shielded Windows}

The air and inert gas cells shall each contain two shielded viewing windows located in the front shielding wall. The inert gas cell shall also contain a third window located in the side shielding wall. The windows shall be made of high-density non-browning glass and provide shielding equivalent to the shielding wall at the window locations.

The centerlines of the windows in the front (south) wall shall be located approximately 58 inches above the floor of the operating area. The location of the windows in the horizontal direction shall be determined by the placement of the in-cell facilities and equipment.

The third window in the inert gas cell shall be located in the center of the side (west) wall and approximately $16-1 / 2$ feet above the cell floor. The exact height is to be determined by the field of view of the window.

The clear vision area of the windows shall be 40 inches by 40 inches hot side and 18 inches by 18 inches cold side. The front wall windows shall be designed to give maximum visibility upwards in the vertical plane and in the area between windows in the horizontal plane. The side wall window shall give maximum visibility in the downward direction.

The windows shall be double sealed (gastight seal at each end) and provisions incorporated for pressurizing the area between the two seals with inert gas.

\subsubsection{Ste reo Viewer}

The hot cell facility will be provided with a single stereo viewer which can be removed from the cold side and used for both cells. The viewer shall contain shielding equivalent to the shielding wall at the location of the wall penetration.

The viewer will have a minimum magnification of $1 \times$ and a maximum of no less than $30 \mathrm{x}$. The magnification range shall be obtained without requiring the changing of the objective optic.

The optics of the viewer that are subject to radiation shall be made of non-browning glass.

The viewer shall have provisions for specimen photography using a removable $35 \mathrm{~mm}$ stereo camera. 
The front wall of each cell shall contain provisions for accepting the stereo viewer. The penetration in the shielding wall shall be as described in Section 6.7.8. The location of the penetrations shall be determined by the placement of in-cell equipment and the viewing windows and manipulators.

\subsubsection{Remote Periscope}

The hot cell facility will not be equipped with a remote viewing periscope. However, to provide for future needs, the front wall of each cell shall contain a penetration at each window to accept one. The penetration shall be as described in Section 6.7.8. The location of the penetrations shall be determined by the placement of in-cell equipment, viewing windows, manipulators, and the manufacturer's recommendations. The location of the penetration shall be such that when a periscope is installed it will not interfere with normal operating procedure.

\subsection{Manipulators}

\subsection{Master Slave}

Each cell shall contain two pairs of master slave manipulators located in the front shielding wall. Each pair of manipulators shall be grouped at a viewing window and located 120 inches above the operating floor and 28 inches apart. The hot cell wall penetrations shall be lined with a carbon steel wall tube supplied by or machined to the manufacturer's specifications.

The manipulators in the air cell shall be the Model 8 type with internal air flow limiting features and the slave halves fully booted. The boot shall be designed to permit replacing it from the cold side, and allow the removal of a manipulator without entering the cell. The manipulator shall contain shielding equivalent to the hot cell wall at the manipulator penetration location.

The manipulators in the inert gas cell shall be of the double seal type (CRL Model A or equal) and designed to be replaced without destroying the integrity of the gas containment. The maximum leak rate through the manipulator and seals shall not exceed $20 \mathrm{cubic}$ inch/day at 3 inches of water pressure differential. Provisions shall be made for pressurizing the sealed area between the manipulator and wall tube (penetration liner) with inert gas. The manipulators shall contain shielding equivalent to the hot cell wall at the manipulator penetration location.

\subsubsection{Electromechanical}

The inert gas cell shall be equipped with a remote control mechanical arm with a minimum load capacity of 65 pounds in any position. The arm shall contain a minimum of five motions as follows:

1 - Hand: parallel jaw gripping

2 - Wrist: rotation in both directions

3 - Elbow: pivot

4 - Shoulder: rotation in both directions

5 - Shoulder: pivot 
The arm shall be mounted on a carriage by means of a telescoping hoist with a minimum travel range of 9 feet. The carriage shall be mounted on a bridge located at the shielding wall lower setback described in Section 6.3. The carriage-bridge combination shall permit rectilinear motion to provide complete coverage of the hot cell working a rea.

The external surfaces of the manipulator shall be made of corrosion resistant materials and the manipulator sealed to allow aqueous decontamination.

The manipulator electrical system shall be designed within the limitations specified in Section 6.9.1.

The control console for the mechanical arm and rectilinear trans port shall be portable and provide stepless variable speed control. The console shall attach to a junction box by means of a quick disconnect electrical plug on a flexible extension cord.

A control console junction box shall be located on the front face of the ine rt gas cell in a position to allow operation of the manipulator from either window. A second junction box shall be located on the side wall of the inert gas cell of the upper viewing window.

Provisions for a similar manipulator shall be incorporated into the air cell by installing the bridge rails and through the wall wiring.

\subsection{Cranes}

Each cell shall contain a remote controlled rectilinear bridge crane of one-ton capacity. The bridge rails shall be located on the upper setback in the shielding wall described in Section 6.3.

The crane shall be fail safe and support a load within its rated capacity with the loss of power. The electrical components of the cranes located within the cells shall be designed within the limitations specified in Section 6.9.1.

Each crane shall be operated by a control box accessible from the normal working position at each viewing window. A secondary manual operator shall be supplied as described in Section 6.2.1.

The lower end of the crane shall have a special disconnect for accepting a hook or any special lifting device required. The disconnect latching mechanism shall be designed for remote operation with a master slave manipulator.

\subsection{Penetrations}

\subsubsection{General}

Of extreme importance in the design of the hot cell is the 450 grams plutonium inventory possible in the Fast Flux Loop. The hazards of ingestion of alpha-emitting particulate matter can readily be seen by the maximum permissible limit of $\angle . U \times 1 U_{-i a} \mathrm{Nic} / \mathrm{mi}$ sel jy lite Jucic 
of Federal Regulations, "Standards for Protection Against Radiation," for Pu-239 concentration in air. With a specific activity of $6.2 \times 10^{-2}$ curie/gram the maximum permissible limit of $\mathrm{Pu}-239$ in the air cannot exceed $3.2 \times 10^{-11}$ grams/cubic meter. The necessity of containing the particulate matter can be appreciated by the fact that the maximum permitted weight of plutonium in air is less than one-millionth that of natural uranium (Reference 7 ).

The design of a la rge high-level alpha-gamma cell with complete containment of particulate matter is a relatively new field and presents many complex problems including that of penetrations of the shielding. To meet the requirements of complete containment a penetration of the hot cell shielding must include the following design features:

1 - Provide adequate radiation shielding

2 - Be gastight

3 - Where required allow items to be put through the penetration without destroying the integrity of the cell containment.

As previously noted the HRLEL and FCF are facilities which have complete containment hot cells, and their designs should be reviewed for possible adaptation to this facility.

\subsubsection{Access Door}

A personnel and equipment access door shall be located in the rear shielding wall of each cell. The door shall be designed for use only after the cell has been remotely decontaminated to a level safe for entry.

The clear passage a rea of the penetration shall be $3^{\prime}-6^{\prime \prime}$ wide by $6^{\prime}-6^{\prime \prime}$ high. The penetration shall be closed by doors on the outer and inner wall surfaces.

The outer door shall be gastight and contain adequate radiation shielding. The door shall have a 180 degree outward swing.

The inner door which will be used to minimize the inflow of air through the penetration, when the outer door is opened, shall be made in two sections and designed to swing outward.

Since the doors are not designed to act as an air lock the door in the inert gas cell shall be used when the cell ventilation has been switched to the once-through air atmosphere system.

The outside shielding wall surrounding the access doors shall have provisions for attaching portable plastic enclosures.

\subsubsection{Transfer Drawer}

Each cell shall contain a 12 -inch diameter transfer drawer located in the rear shielding wall. 
The transfer drawer shall be designed to provide radiation shielding equivalent to the shielding wall at the drawer location and shall be gas. tight. The transfer drawer in the inert gas cell shall be designed so that items may be transferred in or out of the cell without destroying the integrity of the inert atmosphere. The penetration shall have a double seal with provisions for pressurizing with an inert gas.

The inserting and removing of small items from the cells shall be accomplished through the use of a portable shielded cask.

\subsubsection{Transfer Lock}

A transfer lock shall be located in the wall between the two cells. The lock shall be designed to transfer the largest specimen possible in the Thermal Flux Loop.

The transfer lock shall have a gastight door at each end which shall be designed to be operated remotely. The transfer mechanism shall be designed to transport Fast Flux and Thermal Flux specimens as bundles or individual pins.

\subsubsection{Roof Penetrations}

Each cell shall contain a 3 -foot diameter shielded gastight roof penetration for emergency use only. A suggested design using a sealweld closure is shown in Figure 8.

\subsubsection{Drop Tubes}

Each cell shall have two 4 -inch diameter drop tubes, located in the rea $r$ walls, to permit rapid introduction and removal of small items.

The drop tubes in the air cell shall be sealed with gasketed plugs at the cold ends. The drop tubes in the inert gas cell shall be double sealed and designed to be used without destroying the integrity of the inert atmosphere. The area between the seals shall be pressurized with inert gas.

\subsubsection{Spare Penetrations}

To provide flexibility and additional utilization at a later date, spare penetrations shall be provided in the front and rear shielding walls of each cell. The exact number, size and location shall be determined during Title I design.

The penetrations in the air cell shall be sealed with a gasketed shield plug at the cold end. The penetrations in the inert gas cell shall be sealed with a gasketed shield plug at the cold end, and a steel membrane welded to the penetration liner at the hot end. The latter pene tration is illustrated in Figure 8.

\subsubsection{Viewing Equipment}

The shielding wall penetration for the stereo viewer and remote periscope shall be lined with a straight tube closed at the hot side. 
The hot end of the tube shall contain a viewing window of non-browning glass. The penetration liner and viewing window shall be in accordance with equipment manufacturer's recommendations.

When not in use the open end of the tube shall be sealed with a gasketed shield plug. The shield plug shall provide adequate radiation shielding and shall be gastight.

\subsubsection{Systems and Utilities}

\subsubsection{Air Cell}

Penetrations for services and utilities into the air cell shall be " $Z$ " tubes located in the rear and front shielding walls. All service and utility lines shall be cast into seal plugs to minimize in-leakage.

\subsubsection{Inert Gas Cell}

All service and utility lines shall enter the inert gas cell through special penetrations located in the cell floor. The penetration shall be designed so that the lines may be changed without destroying the integrity of the inert atmosphere. Two concepts are illustrated in Figure 8.

The in-cell portions of electrical cables and gas lines shall terminate in remotely operable disconnects. The conceptual design of a disconnect for tubing is shown in Figure 8. For an electrical disconnect it is sug gested that the type being installed in the EBR-II FCF be adapted for use in this facility.

\subsection{Shielded Pits}

\subsubsection{Air Cell}

The air cell shall contain four storage pits 12 inches in diameter by 18 feet long. The pits shall be lined with a stainless steelpipe. The liner shall extend above the floor of the hot cell for a distance of 8 inches. The top of the liner shall contain a loose fitting shielding cap.

The lower end of the pit shall contain an air inlet to provide for loop cooling. The air inlet shall be designed to prevent radiation streaming. The size of the inlet shall be determined by the quantity of air required to keep a loop from exceeding the maximum allowable temperature. The bottom of each pit shall contain a sump connected to the warm waste drain system.

The air cell shall also contain a stainless steel lined cleaning pit for removing radioactive contamination from the outside surface of the loop. The pit shall contain a liquid injection system and motorized scrubbing brushes which will adjust to all configuration of the Fast and Thermal Flux Loops. The top end of the pit shall have a removable shield plug and the bottom end a sump connected to the hot waste drain system. 


\subsubsection{Inert Gas Cell}

The inert gas cell shall have a handling pit 12 inches in diameter by approximately 13 feet deep. The exact size shall be determined by the size of the loops. The depth of the pit shall be such that approximately 2 feet of the loop will extend into the cell for handling purposes.

The pit shall be lined with a stainless steel pipe which will extend 8 inches above the cell floor. The top of the pit shall have a loose fitting shielded cover. The lower end of the pit shall have a sump connected to the hot waste drain system.

\subsection{Special Systems}

\subsubsection{Electrical}

The following criteria shall be used for the design of the in-cell electrical systems and components:

1 - All equipment shall be made of radiation resistant materials.

2 - Wherever possible all electrical motors and wires with organic insulation shall be shielded.

3 - All motor bearings within the inert atmosphere cell shall be lubricated with a low vapor pressure silicon grease and presealed.

4 - The maximum voltage within the inert atmosphere cell shall not exceed 220 volts.

5 - To preclude the possibility of electrical breakdowns the electrical systems within the inert atmosphere shall be designed with a safety factor of 2, i.e., 110 -volt systems shall be designed on the basis of 220 volts, and 220 -volt systems on the basis of 440 volts. Bus bar spacing for 208 - to 220 -volt systems shall be designed on the basis of 1,200 volts.

6 - Flexible cable within the inert atmosphere cell shall be encased in a buna - s sheath and have potted ends to minimize insulation outgasing.

7 - All motors within the inert atmosphere cell shall have U.S. Air Force developed high altitude brushes.

A preliminary estimate of the hot cell electrical loads have been given in Section 5.7, Table 3.

\subsubsection{Lighting}

Hot cell lighting shall be by mercury vapor lamps. The minimum light intensity at the floor level shall be 200 foot-candles.

The lamp or lamp and reflector shall be designed to be remotely replaced. The ballasts shall be located outside of the cells. 
Based on a $20 \%$ utilization factor and a lamp efficiency of 50 lumens/ watt, approximately $4 \mathrm{kw}$ of lighting will be required for each cell.

Approximately $75 \%$ of the lighting in each cell shall be on the $120 / 208$ commercial power bus with a minimum of $25 \%$ on the $120 / 208$ diesel commercial bus.

\subsubsection{Pneumatic}

Pneumatic systems will be required for the following:

1 - Pneumatic operators (if used)

2 - Inert gas barriers in-cell wall penetrations

3 - Specimen and Loop Cooling

4 - Transfer locks

\subsubsection{Pneumatic Operators}

The control supply for pneumatic operators located in the air cell shall be instrument air. The exhaust air shall discharge into the cell atmosphere.

The control supply for pneumatic operators located in the inert gas cell shall be the same gas as the cell atmosphere. The discharging of exhaust gas into the cell atmosphere or the use of a closed loop gas system will be dependent on(a) the number of operators, (b) the gas usage rate and (c) the effects on the cell pressure. The size and type of sys tem to be used shall be determined during Title I design.

\subsubsection{Cell Wall Penetrations}

As previously described, equipment and penetrations in the walls of the inert gas cell will contain buffer zones of inert gas to prevent inleakage of air. These buffer zones shall be supplied from a manifold sys tem with inert gas at 1 psig. The gas line to each penetration shall contain a flow meter, located near the penetration, for leak detection purposes.

\subsubsection{Specimen and Loop Cooling}

To prevent overheating of irradiated specimens, within the hot cell, auxiliary gas cooling will be required. The cooling gas will be supplied by an open circulation system which will draw gas from the cell atmos phere, pass it over the specimens or loops and discharge back to the cell atmosphere. The requirements of the systems are presented as part of the Inert Gas Cell Ventilation System.

\subsubsection{Transfer Locks}

An inert gas supply will be required for pressurizing the cell trans fer locks. This system is presented as part of the Inert Gas Cell Ventilation System. 


\subsubsection{Vacuum Cleaner}

Each cell shall be supplied with a vacuum cleaning line to assist in decontamination. Particulate matte $r$ shall be removed by a cyclone separator located between the pickup wand and the vacuum cleaner. The particulate matter removed in the separator shall be collected in a dis. posable container which shall be remotely removable.

The separator shall be located inside of the hot cell. The location of the vacuum cleaner (in the cell or in a warm area) shall be determined during Title I design. If the vacuum cleaner is located outside of the cell, the discharge shall be fed back into the cell.

\section{9 .5 Vacuum}

A high vacuum system will be required for pumping down the trans fer locks, transfer cask and loops. This system is presented as part of the Inert Gas Cell Ventilation System.

\subsection{Ventilation System}

\subsection{0 .1 Air Cell}

The ventilation system for the air cell is part of the building ventila tion system described in Section 5.4.2.2 and shown in Figure 4. Air will be drawn into the hot cell from the warm areas of the building through a roughing filter, and discharged out of the cell through roughing and absolute filters into the building exhaust system.

For normal operation the air flow through the cell will be $400 \mathrm{cfm}$ providing five changes per hour. For emergency conditions a stand-by exhaust fan will increase the flow rate to $800 \mathrm{cfm}$. The system has been sized to maintain the cell pressure at $1-1 / 2$ inches of water below ambient. During maintenance and cell cleanup, $2,050 \mathrm{cfm}$ of air will be available for flow through the cell access door which will maintain a face velocity through the opening ranging from approximately 90 to $175 \mathrm{ft} / \mathrm{min}$.

The air shall be introduced into the cell at two places along the upper end of the rear shielding wall. The discharge air intakes shall be located at the bottom of the rear shielding wall along with the discharge filters. The air shall be ducted upward and out of the cell at the top of the rear wall. The discharge filters shall be designed for remote replacement.

\subsubsection{Inert Gas Cell}

The ventilation system for the inert gas cell is a recirculating helium system and has been designed to:

a) Maintain an atmosphere of purity suitable for carrying out the operations scheduled for the cell.

b) Maintain the pressure within the cell at a level that is negative with respert to the surroundings.

c) Maintain the temperature within the cell at a suitable level. 
The system is schematically illustrated in Figure 9. A detailed description and analysis of the system is presented in Design Data Sheet M-6004, "Hot Cell Facility Inert Atmosphere Systems," which is included in this document as Appendix D.

\subsection{Liquid Metal Systems}

Liquid metal systems shall be provided for the filling of irradiated loops or new loops containing irradiated specimens.

A detailed description of the systems that will be required is presented in Design Data Sheet M-6003, "Hot Cell Facility Liquid Metal Systems," which is included in this document as Appendix C. 


\section{WARM AREA}

\subsection{General}

Those areas in which low level radioactive materials will be handled as normal operating procedures or are suspect to radioactive contamination have been designated as warm areas (Zone $B$ ).

The containment of radioactive material within the warm area will be obtained through the use of controlled access, pressure differentials and ventilation flow paths.

The warm areas will be located on three levels of the facility as shown in Table 6 and Figure 3. Access to the lower areas will be through a flight of stairs within the warm area and an equipment hatch located in the floor of the warm area at Elevation 101 feet.

All concrete surfaces within the warm areas shall have a dense smooth surface and shall be coated with a phenolic base radiation-resistant paint, chemically inert to aqueous decontaminants.

All floors shall have warm waste drains and shall be pitched to ensure positive drainage.

Controlled access to the warm areas shall be maintained by having the normal personnel entrance and exit through the change rooms. Additional access shall be provided by an equipment door between the cold and warm area, and an outside truck door containing an emergency personnel exit. These additional doors shall be normally locked and under administrative control.

All exterior doors shall be gastight and similar in design to doors within the ATR building.

\section{Table 6}

\section{HOT CELL FACILITY WARM AREAS}

\begin{tabular}{|c|c|c|}
\hline Building Elevation (Feet) & Area Use & $\begin{array}{c}\text { Approximate Floor Area } \\
\text { (Square Feet) } \\
\end{array}$ \\
\hline \multirow[t]{2}{*}{79} & $\begin{array}{l}\text { Hot Cell Inert Gas } \\
\text { Recirculation } \\
\text { Equipment }\end{array}$ & 590 \\
\hline & Transfer Cask & 340 \\
\hline 87 & $\begin{array}{l}\text { Warm Area Mainte- } \\
\text { nance } \\
\text { Building Ventilation }\end{array}$ & $\begin{array}{l}730 \\
520\end{array}$ \\
\hline 101 & $\begin{array}{l}\text { Hot Cell Access } \\
\text { Radioactive De- } \\
\text { contamination } \\
\text { Personnel Change } \\
\text { Room }\end{array}$ & $\begin{array}{l}430 \\
220 \\
125\end{array}$ \\
\hline
\end{tabular}




\subsection{Elevation 101 Feet}

\subsubsection{Hot Cell Access Area}

The hot cell access area is a high bay area located at the rear of the hot cells. As shown in Figure 3 the area will contain the lower level access hatch and a portion of the transfer canal. The lower level access shall be covered with a removable flush floor plate and shall be capable of passing the largest piece of equipment required on the lower levels. The top of the canal shall be covered with removable flush floor plates. Both openings shall be surrounded by raised curbing.

The area shall contain a bridge crane capable of raising the loop transfer cask located at Elevation 79 feet. Services to this area shall be designed in accordance with Section 5.

The access area to the viewing window, located in the east wall of the inert gas cell (Figure 3), shall be considered as part of the warm area, and shall be isolated from the clean areas of the building. Normal access to the viewing window shall be by ladde $x$ from the hot cell access area. A normally locked emergency exit shall be provided from the area at Elevation 113 feet.

\subsubsection{Transfer Canal}

The transfer canal within the hot cell facility will be located in the hot cell access area as shown in Figure 3. The canal will be an extension of the ATR storage canal and shall be of similar construction. A knockout section, to accommodate the transfer canal, has been incorporated into the west wall of the ATR building.

The thickness of the canal walls shall be determined by structural requirements, shielding considerations and space limitations in the subcell warm area. The shielding shall be based on one fully ir radiated Thermal Flux Loop in the canal. The allowable radiation level outside of the canal shall be determined during Title I.

\subsubsection{Decontamination Area}

The decontamination area will be a shielded room adjacent to the hot cell access area which shall be used to remove low level radioactive contamination from equipment and to store highly radioactive items when contained in suitable shielding.

The area shall contain the following equipment:

I - Stainless steel sink with hot and cold water and drainage into the warm waste system.

2 - Stainless steel worktable.

3 - Steam decontamination chamber。

4 - Storage containers for solid radioactive waste. 
The size and location of the equipment and a rea shielding requirements shall be determined during Title I.

\subsubsection{Warm Change Room}

The normal entrance and exit from the warm areas shall be through a warm change room as shown in Figure 3. The change room shall contain the following:

$$
\begin{aligned}
& 1 \text { - Pass-through shower. } \\
& 2 \text { - Toilet facilities. } \\
& 3 \text { - Sinks. } \\
& 4 \text { - Benches. } \\
& 5 \text { - Lockers. } \\
& 6 \text { - Storage racks. }
\end{aligned}
$$

The quantity of each of the above items shall be determined during Title I design.

\subsection{Elevation 87 Feet}

\subsubsection{Ventilation Area}

The lower level ventilation room located at Elevation 87 feet shall contain the following equipment:

1 - Two building ventilation exhaust fans.

2 - Shielded roughing filter bank.

3 - Shielded absolute filter bank.

4 - Building isolation damper.

The partition walls and roof of the area shall be solid concrete for shielding purposes. The actual thickness shall be determined during Title I design.

\subsubsection{Maintenance Area}

The maintenance area located at Elevation 87 shall be used for maintenance and storage of warm equipment.

The equipment to be provided in this shall consist of:

$$
1 \text { - Lathe. }
$$

2 - Drill press.

3 - Band saw.

4 - Workbenches.

5 - Storage lockers.

6 - Grinders.

7 - Welding machine.

8 - Small manual and electric tools. 
The size of the equipment as well as the need for additional items shall be determined during Title I design.

\subsection{Elevation 79 Feet}

The warm areas located at Elevation 79 feet will contain the loop transfer cask, liquid metal fill systems and inert gas recirculation equipment. These items are described in Sections 9.6, 6.1 and 6.10.2 respectively. 


\section{CLEAN AREA}

\subsection{General}

With the exception of the controlled clean area and the loop and liquid metal handling area, the clean areas listed in Table 7 shall be treated as ordinary work space and designed in a manner consistent with ATR practices.

Table 7

HOT CELL FACILITY - CLEAN AREAS

I - Elevation 98 Feet:

Approximate Floor Area (Square Feet)

Controlled Clean Area

575

II - Elevation 101 Feet:

Cold Change Room

350

Radiation Control Office

80

Loop and Liquid Metal

Handling Area

300

III - Elevation 113 Feet:

Offices

480

Lavatories

260

Darkroom

72

Electrical Switchgear Room

Heating and Ventilation

Equipment Room

590

\subsection{Controlled Clean Area}

The controlled clean area shall be designed on the basis of the criteria for warm areas presented in Section 7.1.

The use of an overhead monorail or special fixture for handling the master-slave manipulators shall be determined during Title.I. design.

\subsection{Loop and Liquid Metal Handling Area}

The loop and liquid metal handling area shall be designed as a standard fireproofed work a rea with the following additions:

1 - The floor in all liquid metal handling areas shall be lined with a welded carbon-steel

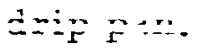

2 - All liquid metal handling equipment shall be shielded with sheet steel partitions. 
The equipment layout shall be designed so as to provide sufficient space for working on a loop when placed in a horizontal position. A description of the liquid metal systems and equipment is presented in Design Data Sheet M-6003 "Hot Cell Facility Liquid Metal Systems," which is included in this document as Appendix C.

A one-ton bridge crane shall be provided for handling of loops in a vertical position.

\subsection{Cold Change Room}

The cold change room (elevation $101 \mathrm{feet}$ ) will be located adjacent to the warm change room, and connected to it by a pass-through shower (Section 7.2.4, item 1) and personnel access door. The change room shall contain the following:

1 - Toilet facilities.

2 - Sinks.

3 - Benches.

4 - Lockers.

5 - Storage racks. Title I.

The quantity of each of the above items shall be determined during

\subsection{Darkroom}

The darkroom located at Elevation 113 feet shall contain sufficient equipment and facilities for the following:

1 - Developing and viewing $X$-ray negatives.

2 - Developing, enlarging and printing $35 \mathrm{~mm}$ film.

3 - Developing and printing $8 \times 10$ photographic plates. 


\subsection{General}

The hot cell facility design and loop handling procedures have been based on the USAEC-IDO design objectives (Reference 6) and requirement that the loops be transferred from the reactor to the hot cell through the ATR canal. (Reference 5.)

The loop handling procedures described in this section concern only those phases associated with the hot cell. The criteria for removing and installing a loop in the reactor as well as transporting a loop in the canal is presented in Part II of this document.

The principal operations for handling irradiated Fast and Thermal Flux Loops are shown in Table 8.

Table 8

\section{HOT CELL LOOP HANDLING OPERATIONS}

I - Post-Irradiation

1 - Transfer loop from canal to Air Cell.

2 - Transfer loop from Air Cell to Inert Gas Cell.

3 - Replacement of thermal neutron filter (Fast Flux Loop only).

4 - Open loop.

5 - Remove specimen.

I I - Pre-Re-irradiation

1 - Insert specimen into the loop.

2 - Close loop.

3 - Fill loop with liquid metal.

4 - Seal fill lines.

5 - Tránsfer loop from Inert Gas Cell to Air Cell.

6 - Clean loop.

7 - Transfer loop from Air Cell to canal.

The handling procedures described in the following sections have been developed on the basis of:

a) the reference design of the loops (References 8, 9 , and 10),

b) the requirement that the specimen surface temperature not exceed $1,000 \mathrm{~F}$,

c) the design objective of re-using the Thermal Flux Loop,

d) the desire for a minimum turn-around time.

The operational procedures and equipment required for the handling of $F=-4$ and Thermal $F$ lux Ionna within the hot cell facility are discussed in the following sections and presented in detail in Appendix $G$. 
All of the operations listed in Table 8 involving radioactive materials will be performed in the inert gas cell. The air environment cell will be used as an area to allow the loops to dry after removal from the canal, and to remove radioactive contamination from the outside of the loops prior to returning them to the canal.

There are many areas within the handling procedures in which extensive Title I design and research and development effort will be required. These areas are outlined in Section 9.7 of this document.

An area directly related to the feasibility of re-using the Thermal Flux Loop is the design of the liquid metal and helium fill lines at the top of the loop. As can be seen from the conceptual design of the Thermal Flux Loop (Figure 10) the limited space available plus the need for leaktight sealing of the fill lines presents a difficult problem when designing for remote handling. To date a satisfactory solution to this design problem has not been found. However, the handling procedures for re-use of the loop have been developed and are being presented in the anticipation that the problem will be solved.

If the fill lines cannot be designed to permit remote opening and sealing, the design objective of re-using the Thermal Flux Loop and those handling procedures directly related to it will have to be eliminated.

\subsubsection{Loop Design}

The conceptual designs of the Fast and Thermal Loops are presented in References 7,8 and 9. The features of the loop which directly affect the handling procedures are:
a) Loop end closure design.
b) Top end fill line design.
c) Design of the loop in the area of the test specimen.
d) Design of the loop pump-motor and bearings.

The design of the loop and loop end closure affects the method of removing the test specimen. The conceptual design of the lower end of a loop which will permit remote removal and insertion of irradiated specimens is shown in Figure 11 . The handling procedures based on this design are presented in Sections 9.3, 9.4.2 and 9.4.3.

The problems associated with the fill lines which terminate at the top end of the loop have been noted in Section 9.1 and are presented in detail in Design Data Sheet M-600l which is included in this document as Appendix A.

The design of the loop in the area of the test specimen controls the amount of specimen decay heat that is transferred to the surroundings and, therefore, the procedures to be used and the decay time required before the loops and specimens can be safely handled. Since the exact mechanical design of the loops will not be fixed until Title I, all quantitative numbers relating to decay times and handling are only approximations and are presented to provide an order of magnitude basis for evaluations and further design work. 
The design of the loop pump-motor and bearings is such that liquid metal should not be permitted to come in contact with these parts. Although liquid metal vapors may be mixed with the helium cover gas in this region during loop operation, the operating experience with the Pratt \& Whitney $P W-19$ loop indicated that these vapors were not detrimental to the components. However, the parts are not designed to be flooded with liquid metal and the loops will have to be maintained in a vertical position whenever filled with liquid metal.

\subsubsection{Decay Time and Loop Turn-Around}

The surface temperature of an irradiated specimen is a function of:
a) irradiation history
b) decay time
c) specimen environment

The approximate decay periods required for handling Fast and Thermal Flux Loops after 10,000 hours of irradiation at the reference specimen power ( 150 and $1,500 \mathrm{kw}$ respectively) are shown in Tables 9 and 10. A detailed analysis of the decay periods and associated loop conditions is presented in Design Data Sheets R-6007 and R-6011, which are included in this document as Appendices $E$ and $F$ respectively.

Table 9

DECAY PERIODS FOR FAST FLUX LOOP HANDLING a/

\begin{tabular}{|c|c|c|c|c|}
\hline \multicolumn{2}{|l|}{ Environment } & \multirow[b]{2}{*}{ NaK Pump } & \multirow{2}{*}{$\begin{array}{c}\text { Secondary } \\
\text { Coolant } \\
\text { (Helium) } \\
\text { Flow }\end{array}$} & \multirow{2}{*}{$\begin{array}{l}\text { Minimum } \\
\text { Decay Time } \\
\text { Required b/ } \\
\end{array}$} \\
\hline Loop & Specimen & & & \\
\hline $\begin{array}{l}\text { Stagnant } \\
\qquad 100 \mathrm{~F} \text { Water }\end{array}$ & $\mathrm{NaK}$ & On & Off & $1 / 4$ Hour \\
\hline $\begin{array}{l}\text { Stagnant } \\
\text { l00 F Water }\end{array}$ & $\mathrm{NaK}$ & Off & Off & 4 Days \\
\hline $\begin{array}{l}\text { Stagnant } \\
78 \mathrm{~F} \mathrm{Air} \mathrm{or} \\
100 \mathrm{~F} \mathrm{Helium}\end{array}$ & $\mathrm{NaK}$ & Off & Off & $2-1 / 2$ Weeks \\
\hline $100 \mathrm{~F}$ Flowing Helium c/ & $\begin{array}{c}\text { Stagnant } \\
\text { Helium }\end{array}$ & Off & Off & 4 W eeks \\
\hline
\end{tabular}

al Specimen surface temperature at 1,000 F.

b/ Total elapsed decay time out of core after reactor shutdown before environment is tolerable.

c/ Loop pressure tube removed.

Listed as part of the Liquid Metal Loops design objectives (Reference 6)

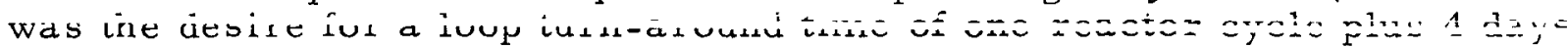
shutdown totaling 21 days. As shown in Tables 9 and 10 this design objective cannot be met. 
It should be noted from the two tables that decay periods of approximately 2-1/2 and 4 weeks, for the Fast and Thermal Flux Loops respectively, will be required before the loops can be brought into the air environment hot cell. Moreover, approximately 4 and 27 weeks will be required before an irradiated Fast or Thermal Flux specimen can be reinserted into a loop. If the inert gas cell environment is argon, the latter two decay periods would increase to approximately 6 and 18 months.

A detailed analysis of the decay periods and the effects of the various environmental conditions will be required during Title I design.

Table 10

\section{DECAY PERIODS FOR THERMAL FLUX LOOP HANDLING a/}

\begin{tabular}{|c|c|c|c|c|c|}
\hline \multicolumn{2}{|c|}{ Environment } & \multirow{2}{*}{$\begin{array}{l}\text { Sodium } \\
\text { Pump } \\
\text { Power } \\
\text { Kw b/ } \\
\end{array}$} & \multirow{2}{*}{$\begin{array}{c}\text { Sodium } \\
\text { Temperature } \\
\mathrm{F} \\
\end{array}$} & \multirow{2}{*}{$\begin{array}{c}\text { Secondary } \\
\text { Coolant } \\
\text { (Helium) } \\
\text { Flow } \\
\end{array}$} & \multirow{2}{*}{$\begin{array}{r}\text { Minimum } \\
\text { Decay Time } \\
\text { Required c } \\
\end{array}$} \\
\hline Loop & Specimen & & & & \\
\hline $\begin{array}{l}\text { Stagnant } \\
\quad 100 \mathrm{~F} \mathrm{Water}\end{array}$ & Sodium & 12 & 975 (Max.) & Off & 10 Seconds \\
\hline $\begin{array}{l}\text { Stagnant } \\
\text { l00 F Water }\end{array}$ & Sodium & 12 & 250 & Off & 8 Days $d /$ \\
\hline $\begin{array}{l}\text { Stagnant } \\
\quad 100 \mathrm{~F} \text { Water }\end{array}$ & Sodium & 12 & 250 (Min.) & Off & $-\quad$ e/ \\
\hline $\begin{array}{l}\text { Stagnant } \\
\qquad 100 \mathrm{~F} \mathrm{Air}\end{array}$ & Sodium & 1 & 975 (Max.) & Off & $4 \mathrm{~W}$ eeks \\
\hline $\begin{array}{l}\text { Circulating } \\
250 \mathrm{~F} \mathrm{Helium}\end{array}$ & $\begin{array}{l}\text { Stagnant } \\
\text { Helium }\end{array}$ & Off & - & Off & 27 Weeks \\
\hline
\end{tabular}

a) Specimen surface temperature at 1,000 F.

b/ Energy added to flowing sodium by primary pump.

c) Total elapsed decay time out of core after reactor shutdown before environment is tolerable.

d/ Total elapsed time before $250 \mathrm{~F}$ sodium temperature is reached.

ef Loop can be held in this condition indefinitely without having the sodium freeze, so long as $25 \mathrm{kw}$ input is maintained in the loop internal heaters.

\subsection{Loop Transfer \\ 9.2.1 Hot Cell - Canal Transfer}

The irradiated loop will be introduced into the air cell through the 12 -inch diameter access penetration located in the cell floor above the canal. The loop will be raised into the cell by the canal transfer cart so that the top end will be visible and within easy reach of the cell manipulators. The description and criteria of the canal transfer cart are presented in Part II of this document. 
With the loop in the raised position the following work is done:

a) Overhead crane cable is attached to the loop.

b) When handling a Thermal Flux Loop the external power and instrumentation cables are removed from the loop and replaced with identical cables originating in the cell.

The mechanism for attaching the crane cable to the loop shall be an electrically operated mechanical quick disconnect. The disconnect shall be designed so that it can be used to remove a loop from the canal transfer cart when in the lowered (transporting) position.

The operations for transferring a loop from the hot cell to the canal will be identical to those listed above except that the sequence will be reversed.

\subsubsection{Inter-Cell Transfer}

Loop transfer between cells will be accomplished through the use of the overhead crane, the 12 -inch floor access ports located above the sub-cell warm area and a transfer cask located in the sub-cell warm area.

The operational procedures for transferring a loop between cells will be similar to those listed in Section 9.2.1.

The description and criteria for the sub-cell transfer cask is presented in Section 9.6.

\subsection{Replacement of Thermal Neutron Filter}

As described in Reference 8 , a the rmal neutron filter is necessary to provide the required Fast Flux Loop nuclear spectrum. In the refer ence design of the Fast Flux Loop, a boron-stainless steel thermal neutron filter will be in intimate contact with the outside surface of the loop pressure tube. With an estimated useful life of four reactor cycles for the thermal neutron filter, remote replacements will be required during the lifetime of the loop.

The detailed operations for replacing the filter within the Inert Gas Hot Cell are presented in Appendix G. The replacement scheme has been based on the concept that the filter and lower section of the loop pressure tube will have to be removed and replaced as a single unit by cutting the latte $r$ at a point above the filter.

Further investigation of the filter design to improve the life and replacement requirements will be undertaken during Title I.

\subsection{Specimen Removal \\ 9.4.1 General}

The snecimen ends of the package loops consist of a liquid metal containment tube inside of a loop pressure tube (Figure 11). 'The design of the loops necessitates that a specimen be removed from the lower end of the loop. 
In order to minimize the decay time required before an irradiated specimen can be removed without exceeding the maximum allowable temperature, a criterion has been established that specimens shall be kept immersed in liquid metal throughout the entire removal procedure.

The detailed operations for specimen removal presented in Appendix $G$ have been developed for the Fast Flux Loop, but are applicable to the Thermal Flux Loop also. Those operations which are particular to only one of the loops have been noted as such.

\subsubsection{Pressure Tube Removal}

The removal of the Fast Flux Loop pressure tube has been noted in Section 9.3. As in the case of the Fast Flux Loop, the Thermal Flux Loop pressure tube will be removed by making a radial cut in the tube and sliding off the lower section. The cutting location shall be determined during Title $I$.

\subsubsection{Containment Tube and Specimen Removal}

As presently designed, the specimens are located in the proper position by a specimen support structure fastened to the bottom of the containment tube (Figure 11 ). In order to provide a positive means of extracting the specimen from the loop the support structure will be fastened to the specimen also.

The conceptual designs for the Fast and Thermal Flux Loops presented in References 1 and 2 provide for specimen removal through use of a removable closure at the bottom of the containment tube. A detailed analysis of the closure design, which consisted of two threaded plugs sealed with metallic-"o"-rings and a final weld, and its operational requirements indicated that it would not be satisfactory.

The containment tube end closure for the reference designs of the Fast and Thermal Flux Loop is shown in Figure 12. The end cap which will be welded to the containment tube has coarse-pitch shallow threads which can be engaged by a pulling tool for removal of the cap and specimen。

The conceptual design of a special parting and extracting device is shown in Figure 13. The detailed operations for removing the loop end caps and specimens are presented in Appendix G. The procedure has been based on the criteria of maintaining the specimen in liquid metal during and after removal from the loop as noted in Section 9.4.1. The design of the extracting device is conceptual and will require further effort in Title I. As presently conceived the unit will contain a tank of liquid metal into which the bottom end of the loop will be inserted. When the end cap is separated, the specimen will be pulled into the liquid metal in the tank. The additional liquid metal in the loop will drain into the tank and the excess will be directed into a storage tank through use of an overflow drain line. 


\subsection{Specimen Insertion}

\subsubsection{General}

The insertion of a specimen into a Fast or Thermal Flux Loop within the Hot Cell Facility shall encompass the following combinations:

a) New Fast and Thermal Flux Loops and Specimens.

b) Irradiated Fast Flux Specimen in a new loop.

c) Irradiated Thermal Flux Specimen in a new loop.

d) Irradiated Thermal Flux Specimen in an irradiated loop.

e) New Thermal Flux Specimen in an irradiated loop.

The procedures for inserting irradiated specimens into Fast and Thermal Flux Loops, as described in the following sections have been based on having a stagnant inert gas inside of the loop and a flowing inert gas on the outside of the loop.

As was shown in Tables 9 and 10 the insertion of an irradiated specimen into Fast and Thermal Flux Loops cannot be accomplished before approximate decay periods of 4 and 27 weeks respectively. These decay times have been calculated on the basis of using helium as the inert gas and a maximum specimen surface temperature of $1,000 \mathrm{~F}$. Should either of these parameters change, such as using argon instead of helium or lowering the maximum allowable specimen temperature, the decay periods required will increase. It has been estimated that the use of argon would increase the decay times to approximately $1 / 2$ and $1-1 / 2$ years.

The possibility of inserting an irradiated specimen into a loop while immersed in liquid metal was investigated. This method was of particular interest in that it would eliminate the need of any fur ther decay time between specimen removal and reinsertion. Two approaches to the problem consisted of (a) cutting the containment tube at a point above the specimen so that it could be filled with liquid metal into which a specimen could be placed and (b) sealing the loop to a special handling machine containing the specimen in liquid metal. The machine would then force liquid metal up into the loop, insert the specimen and seal the loop containment tube. How ever, neither system proved compatible with the reference designs of the loops, and were discarded.

Additional problem areas that will require extensive study before the feasibility of loop re-use and specimen re-irradiation can be proven are:

a) Design of the top end of the loop to permit remote opening and sealing of the liquid metal and helium fill lines.

b) Msk:mo =nd insmerting wolds.

c) Handling of loops that are approximately 16 feet long. 
These problem areas are discussed in Section 9.7.3.

\subsubsection{Non-irradiated Loops and Specimens}

The pre-irradiation preparation of Fast and Thermal Flux Loops will be accomplished in the Loop and Liquid Metal Handling Area.

The work to be performed will consist of:

a) Locating a specimen in a loop.

b) Sealing the loop.

c) Filling the loop with liquid metal.

d) Operational check of completed assembly.

The handling procedures for the Fast and Thermal Flux Loops shall be similar to those developed by Pratt \& Whitney Aircraft for the PW-19 package loop. The conceptual design of the liquid metal systems and filling procedures for both loops are presented in Design Data Sheet M-6003 which is included in this document as Appendix C.

\subsubsection{Irradiated Specimens - New Loops}

The procedure for installing an irradiated specimen into a new Fast or Thermal Flux Loop will be the same as that used in the nonirradiated case with the exceptions that the operations will have to be accomplished remotely, and that auxiliary cooling of the loop will be required. A conceptual method of providing cooling on the outside of the loop is shown in Figure 14 in which a jacket is clamped to the loop containment tube. Helium drawn from the cell atmosphere will be pumped through the jacket and then discharged back into the cell.

The detailed operations for the insertion of irradiated specimens are presented in Appendix G. These operations have been developed for the Fast Flux Loop, but are applicable to the Thermal Flux Loop with the additional requirement that all components containing liquid metal be maintained at a minimum temperature of $300 \mathrm{~F}$. The conceptual design of the liquid metal systems and filling procedures for both loops are presented in Appendix C.

\subsubsection{Irradiated Specimen - Irradiated Loop}

The insertion of an irradiated specimen into an irradiated loop (for increased loop utilization) is a design criterion for the The rmal Flux Loop only. (See Appendix A.) As previously noted in Section 9.1 the feasibility of re-using the loop has not been shown. However, the following section is being presented on the basis that satisfactory solutions will be found during Title I design and the Research and Development Program。

The physical operations for the insertion of a specimen into a Thermal Flux Loop is presented in Appendix G. The conceptual design of the liquid metal system and filling procedure are presented in Appendix C. The liquid metal system has been designed to circulate sodium through the loop and an external purification system. The basis 
for this system is to provide a means of removing oxide contamina tion from the liquid metal remaining in the loop after a specimen has been removed. While the need for high purity liquid metal within the loop cannot be quantitatively proven, the experience of Pratt \& Whitney Aircraft with their PW-19 loop and general liquid metal systems technology indicates that high oxide concentrations will prevent satisfactory operation of the loops. The problem of liquid metal purity is discussed in Appendix A.

\subsubsection{New Specimen - Irradiated Loop}

The insertion of a new specimen in an irradiated loop (Thermal Flux Loop only) will be essentially the same as indicated in Section 9.5.2 except that the operations will have to be accomplished remotely.

\subsection{Sub-Cell Transfer Cask}

The sub-cell transfer cask will be located in the warm area directly below the hot cells (Figure 3). The cask will be used to (a) transfer irradiated loops between cells, (b) introduce new loops into the cells and (c) transport irradiated loops directly to the NRTS burial grounds or transfer irradiated loops to another cask for dis posal.

The cask shall be designed to the following criteria:

a) The cask shall completely contain the largest size loop.

b) The top of the cask shall contain a remotely ope rable helium leak-tight seal.

c) The cask shall be designed to seal against the transfer ports located in the floor of the hot cells.

d) The cask shall contain adequate shielding so that the external radiation shall not exceed 1 $\mathrm{mr} / \mathrm{hour}$.

e) The cask shall contain a vacuum system capable of evacuating the internal volume, when containing a loop, to $10^{-3} \mathrm{~mm}$ of $\mathrm{Hg}$ within one minute.

f) The cask shall contain a helium gas system for pressurizing the internal area. The system shall also be capable of circulating the inert gas to provide cooling of an irradiated loop and specimen.

g) The cask shall contain an internal lifting mechanism for raising a loop into the hot cell.

h) The cask shall contain retractable power and instrumentation cables to permit operation of the Thermal Flux Loop pump and heaters during transfer. 
i) The cask shall be mounted on a dolly which will traverse between the floor transfer port of each cell and the sub-cell warm area access hatch. The cask shall be removable from the dolly.

The transporting of an irradiated loop to the NRTS burial grounds in the sub-cell transfer cask, or in another cask, will be dependent on the weight and complexity of the latter and shall be determined during Title I. The design requirements for transporting of irradiated loops for disposal shall be determined during Title I.

\subsection{Research and Development}

\subsubsection{General}

The complex design of the loops and remote handling procedures leave many areas in which extensive research and development will be required. In many cases adaptation of previously used hot laboratory techniques may prove satisfactory, while in others new and radical methods must be devised. Until a satisfactory solution to many of the problems can be demonstrated, the feasibility of re-irradiating specimens and of re-using of the Thermal Flux Loop cannot be proven. The major problem areas are presented in the following sections.

\subsubsection{Specimen Removal}

The equipment required for the opening of irradiated loops and the removal of specimens is of a highly specialized nature. The mechanisms used for disassembly, consisting of chucks, tool holders, tools and associated drives and controls, will require extensive development and check-out. Such matters as speeds and feeds, effects of the previous irradiation on the materials to be machined, details of tooling, and methods of positioning and control, will require further investigation.

The device used for opening a loop and removing the specimen is another area requiring extensive investigation. Such matters as cooling, strength of loop materials under elevated temperatures, stability of dimensions under the given conditions, and other problems must be given careful consideration before construction. After construction, the device, like all other equipment to be used in the hot cells, must be given an extensive check-out in actual operation to insure the utmost in reliability。

In addition to the above problems the design and operation of the equipment will be complicated by the criterion that the specimen be maintained in liquid metal during normal removal from a loop as well as during abnormal conditions.

\subsubsection{Specimen Insertion}

The design of the equipment required for insertion of an irradiated specimen will present many of the problems associated with the removal tool. Additional problems will be encountered by the need to provide inert gas cooling on the outside of the loop plus the exacting requirements for closing the loop, such as aligmment, welding and inspection. 
The making of the various welds will require investigation to determine what methods and equipment will best solve the problems complicated by remote handling, welding of metal which has been subjected to varying periods and intensities of radiation, the extremely high quality of weld required, and the possibility of trace contamination by liquid metal. The ability of obtaining satisfactory welds by relying on the hot cell inert atmosphere as a cover gas for arc-welding will have to be determined.

The more common factors such as speed of welding, manner of handling the filler metal (continuous wire feed or preplaced ring), number of passes, and electrical characteristics of the arc required for optimum performance will also require investigation.

The inspection of the welds poses many complex problems. The liquid penetrant inspection, to be effective, requires visual monitoring of a high degree of resolution. One matter for investigation is whether to provide remote viewing in quantity and quality to permit the inspections to be made conveniently and expeditiously, or to move the loop to the viewing facility at an increased cost in elapsed time and of labor. The exact methods of applying the dye penetrant and developer and of cleaning the area afterwards must be worked out by actual experimenta tion in order to obtain the essential degree of reliability that will be required.

The radiographic examination of the welds poses a special problem because of the presence of radiant energy from the specimen. The best method of shuttering and other details of the equipment as well as techniques and photographic materials can only be determined by experimenting on a sufficient scale to insure dependability of results.

The inspection of the welds for leak tightness through use of a mass spectrometer leak checker is another field requiring investigation. With helium as the hot cell atmosphere a different tracer gas will have to be used. A mass-spectrometer leak checker with a maximum sensitivity $5 \times 10^{-9}$ atmospheric cc/sec。 (compared to $1 \times 10^{-9}$ for helium) is avail able for use with argon. The satisfactory use of a mass-spectrometer leak checker using a tracer gas other than helium will be dependent on the following items:

a) The inert gas inside of the loop will have to be a mixture of helium and argon. The exact mixture that will provide sufficient argon to be detectable, yet have sufficient helium to prevent specimen over temperature will have to be determined.

b) The sensitivity of the leak checker when located outside of the cell and connected to the sniffing head by long lines with filters.

\subsubsection{Thermal Flux Loop}

In addition to the problems encountered when inserting an irradiated

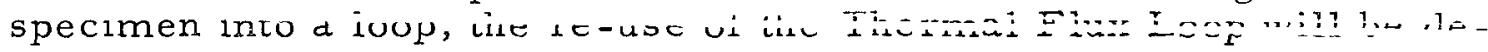
pendent on the design of the top end of the loop and the feasibility and 
efficiency of the external circulating sodium purification system. The sodium system shown in Design Data Sheet M-6003 (Appendix C) is complex in design and operation and an operational mock-up will be required to demonstrate its feasibility and effectiveness.

The helium and sodium fill lines located at the top of the loop must be designed to permit remote opening, extending, and sealing. Because of the limited space and large number of lines emanating from the loop, the fill lines will necessarily be close together. The limited space presents major problems in locating tools to perform the required operations and designing a way to make temporary connections to the fill lines. Various methods have been proposed, including compression couplings, flared fittings, silver-soldering, brazing, and welding. However, bearing in mind that clearances are in most cases quite close, the order of reliability of performance required is extremely high, and all must be performed by means of remote handling and viewing, extensive experimentation to determine the optimum equipment and techniques will be required. 


\subsection{General}

The primary purpose of the hot cell is to allow the experimenter to visually inspect test specimens after varying stages of irradiation. The inspection requirements for the Hot Cell Facility have been set forth in USAEC-IDO letter RTR:JCMc, H. M. Leppich to R. H. Gordon, April 20, 1962, (Reference 6) and modified in Design Data Sheet M-6001 (Appendix A).

The Hot Cell Facility has been designed on the basis of the following three considerations:

a) Test specimens would not contain refractory metal cladding.

b) Failed test specimens would not be re-irradiated and, therefore, would be returned to the experimenter for inspection at his own facility.

c) Only nondestructive testing will be performed within the facility (Reference 6).

\subsection{Specimen Description}

The reference test specimens for the Fast and Thermal Flux Loops will consist of a seven-pin bundle of stainless-steel clad fuel rods contained in a shroud tube. Spacing between rods will be maintained by spacer wire spirally wrapped around each rod.

The dimensions of the Fast and Thermal Flux specimens are presented in Table 11 and shown in Figures 15 and 16 respectively.

Table 11

\section{REFERENCE SPECIMEN DIMENSIONS}

\begin{tabular}{|c|c|c|}
\hline & $\begin{array}{l}\text { Fast } \\
\text { Flux }\end{array}$ & $\begin{array}{c}\text { Thermal } \\
\text { Flux } \\
\end{array}$ \\
\hline Specimen OD, - Inches & 1.18 & 2.41 \\
\hline Specimen Length - Inches & 18 & 48 \\
\hline No. of Fuel Pins & 7 & 7 \\
\hline Fuel Pin Diameter - Inches & 0.282 & 0.560 \\
\hline Spacer Wire Diameter - Inches & 0.023 & 0.090 \\
\hline
\end{tabular}

\subsection{Inspection Requirements}

Space will be provided within the Hot Cell Facility for the inspection of irradiated Fast and Thermal Flux Loop test specimens. The inspection requirements are shown in Table 12 .

As directed by AEC-IDO in Reference 6, the architect-engineer shall not supply the tools and fixtures to perform the listed examinations. How -

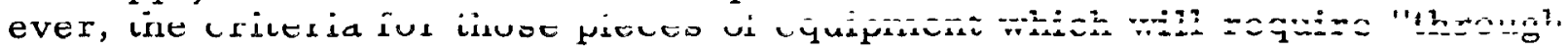


the wall" installations have been included as part of the hot cell design and have been presented in Section 6.4 .

Table 12

TEST SPECIMEN INSPECTION REQUIREMENTS

Fuel Type

Examinations

Ceramic Cermet Metallic

Before Removal of Fuel From Bundle

1. Macro and Visual Inspection (up to 30X) $\mathrm{x}$

2. Macro Photography

3. Measurement of Fuel Spacing

$\begin{array}{ccc} & \mathbf{x} & \mathrm{x} \\ \mathrm{x} & \mathrm{x} & \mathrm{x} \\ \mathbf{x} & \mathrm{x} & \mathbf{x}\end{array}$

After Removal of Fuel From Bundle -

Nondestructive Testing

1. Macro Inspection (up to $30 \mathrm{X}$ )

2. Macro Photography

3. Fuel Outside Dimensions

4. Density and/or Weight

5. Gamma Scan for Relative Activity and Fuel Redistribution

6. Electrical Resistivity

7. Leak Detection

8. Nondestructive Measurement of Meat

$\begin{array}{ccc}\mathrm{x} & \mathrm{x} & \mathrm{x} \\ \mathrm{x} & \mathrm{x} & \mathrm{x} \\ \mathrm{x} & \mathrm{x} & \mathrm{x} \\ \mathrm{x} & \mathrm{x} & \mathrm{x}\end{array}$

9. Fission Gas Release and Reseal of Tubes

10. Eddy Current Test for Bond

11. Ultrasonic Testing

$\mathbf{x} \quad \mathbf{x}$

- $x \quad x \quad$ a

$\mathrm{x} \quad \mathrm{x}$

$\mathrm{x}-\mathrm{x}$ b

a) Clad integral with fuel.

b/ Sodium bonded elements.

\subsection{Specimen Cooling}

When removed from a loop, the irradiated test specimen will be immersed in liquid metal. The test specimen may be kept within this environment for indefinite periods without exceeding the maximum allowable surface temperature.

For inspection purposes, the test specimens will have to be removed from the liquid metal environment. However, the decay heat generation of an irradiated specimen while in a bundle configuration would soon cause an overtemperature condition. The rates of temperature rise for irradiated specimens are presented in Figures 17 and 18. As shown in these 
figures there is not sufficient time to disassemble the bundles and, therefore, auxiliary cooling must be provided as soon as the specimens are withdrawn from the liquid metal.

Two concepts for providing auxiliary gas cooling are shown in Figures 19 and 20. The first concept is for the fuel bundle when contained in a shroud and will force the cooling gas through the specimens in an axial direction. The second concept will be used for fuel bundles without shrouds and consists of a distribution plenurn for forcing cooling gas through the bundle in a cross flow direction. The cooling gas in both cases will be cell atmosphere.

The thermal analyses for the Fast and Thermal Flux specimen handling and their cooling gas requirements are presented in Design Data Sheets $R-6009$ and $R-6010$ respectively which are included in this document in Appendixes $\mathrm{H}$ and $\mathrm{I}$.

When separated, the individual fuel pins will not require any auxiliary cooling, and therefore do not present any special handling problem.

\subsection{Specimen Design}

The test specimen design will be the responsibility of the experimenter. However, for successful hot lab operation, the specimen will be required to meet the following criteria:

a) The specimen shall be designed with sufficient clear ance to permit removal from the loop allowing for warpage and bowing.

b) The lower end of the specimen shall be compatible with the loop containment tube support structure and shall be designed for remote removal.

c) The upper end of the specimen (when contained in a shroud) shall be designed to mate with the auxiliary cooling gas nozzle.

d) The upper end of the specimen (when not in a shroud) shall be designed to accept a pickup tool for remote removal from the liquid metal bath.

e) The specimen, when contained in a shroud, shall be designed for easy removal from the shroud when inspection of the bundle is desired.

f) When inspection of individual fuel pins is desired, the fuel bundle shall be designed for remote dis assembly by nondestructive means.

\subsection{Specimen Cleaning}

After removal from the liquid metal environment, inspection of the test specimen will require that any residual liquid metal be removed. The cleaning of liquid metal from an irradiated specimen after a short 
decay time will present a problem because of the high decay heat generation, and will require further investigation during Title I. Some of the problems associated with the use of conventional cleaning methods are:

a) Decomposition of alcohols.

b) Hot spots caused by oxide formation when using a wet gas.

c) Pu, U-water reaction in a fuel element with a failed cladding.

d) Water reaction with the liquid metal bond in a fuel element with a failed cladding. 


\section{REFERENCES}

1 - Blessing, W. G., et al。, "Conceptual Design of an In-Pile Package Loop for Fast Reactor Fuel Testing," Report No. APDA 144, Atomic Power Development Associates, Inc., July 1961.

2 - Blessing, W. G., et al., "Conceptual Design of an In-Pile Package Loop for Sodium-Cooled Thermal Reactor Fuel Testing," Report No. APDA 145, Atomic Power Development Associates, Inc., September 1961.

3 - Advanced Test Reactor - ATR Preliminary Safety Analysis Report, Babcock \& Wilcox Co., and Ebasco Services Incorporated, IDO 24040, April 1962。

4 - USAEC-IDO Letter ECE: MEA, H.M. Leppich to R。H.Gordon, March 8, 1962 .

5 - Record of telephone conversation from M.E. Autio, IDO; W. C. Hayden, IDO; T.E. Hopkins, IDO; to J. A. Scarola, Ebasco; Ebasco File No。I-C-3.4, March 22, 1962.

6 - USAEC-IDO Letters RTR: JCMc, H。M。 Leppich to R。H.Gordon, April 20, 1962。

7 - L. R. Kelman, et al。, The Safe Handling of Radioactive-Pyrophoric Materials, Argonne National Laboratory, ANL5509, December 1955.

8 - "Design Criteria for a Fast Flux Liquid Metal Loop in the Advanced Test Reactor," Ebasco Services Incorporated and the Babcock \& Wilcox Co., IDO-24041, March 1963.

9 - "Design Criteria for a Fast Flux Liquid Metal Loop in the Advanced Test Reactor," Ebasco Services Incorporated and the Babcock \& Wilcox Co., IDO-24041 Supplement 1, March 1963.

10 - "Summary Report of Design Criteria for a Thermal Flux Loop Liquid Metal Loop in the Advanced Test Reactor," Ebasco Services Incorporated and the Babcock \& Wilcox Co., IDO-24042, March 1963. 
-

-

0 


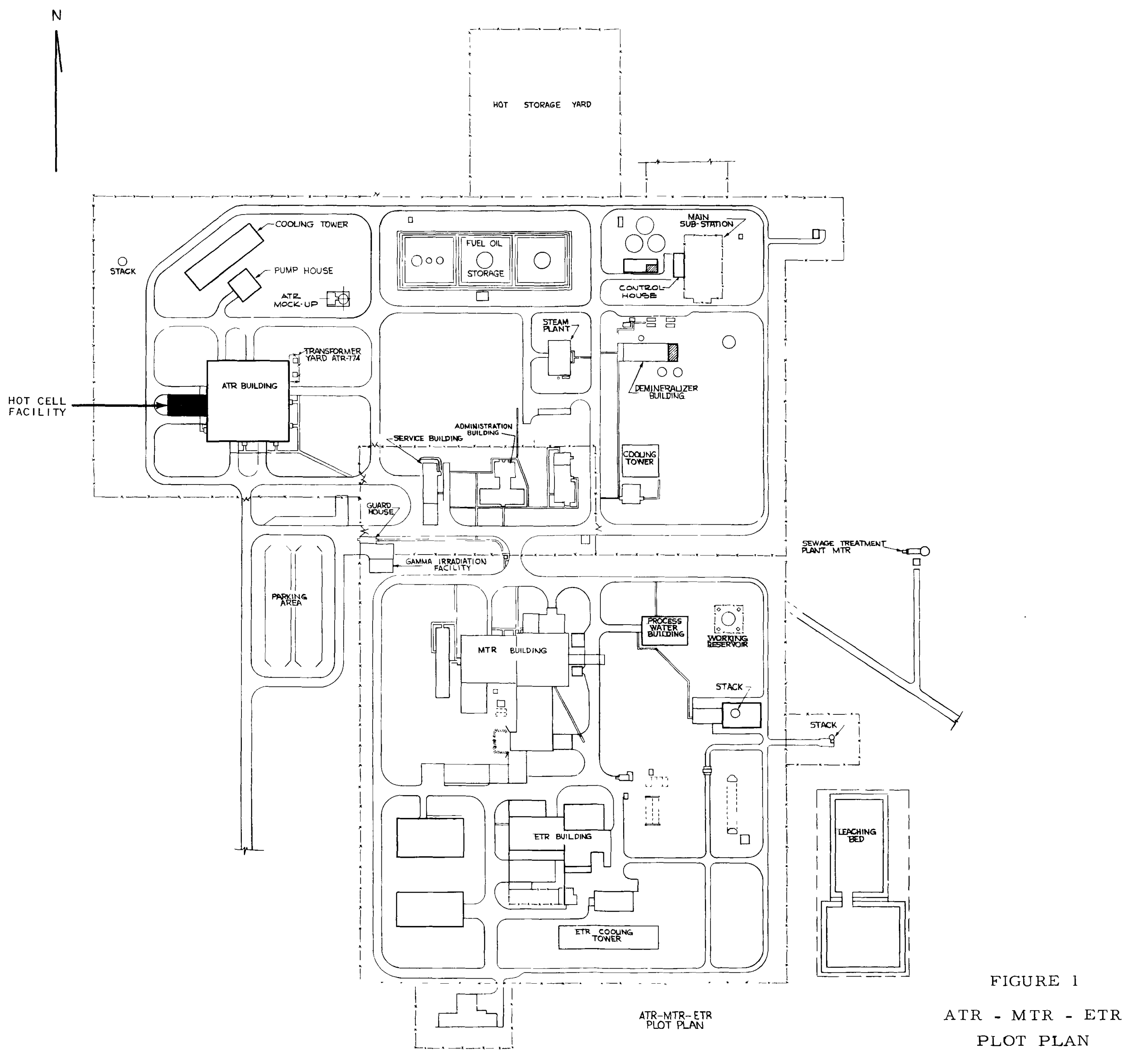




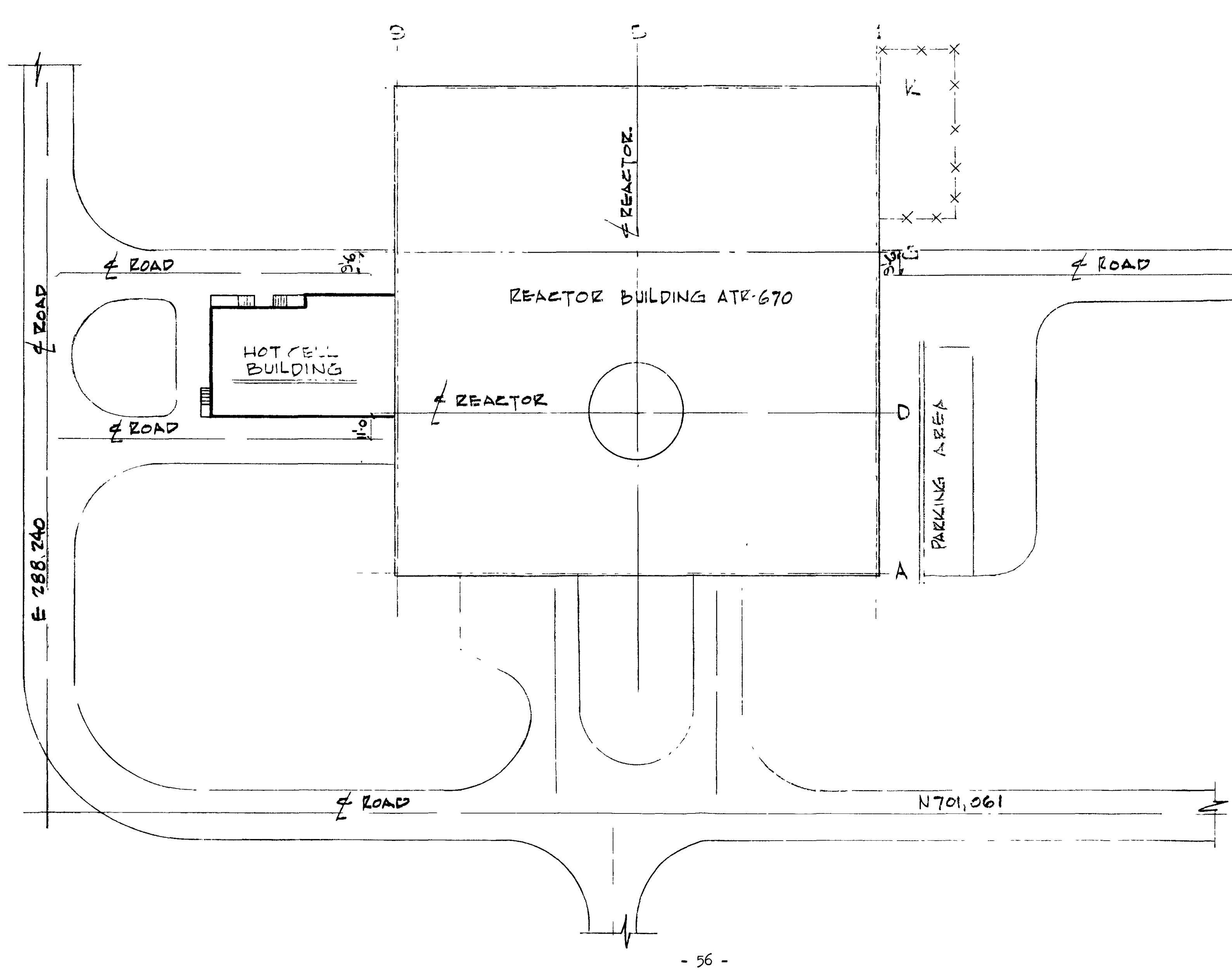



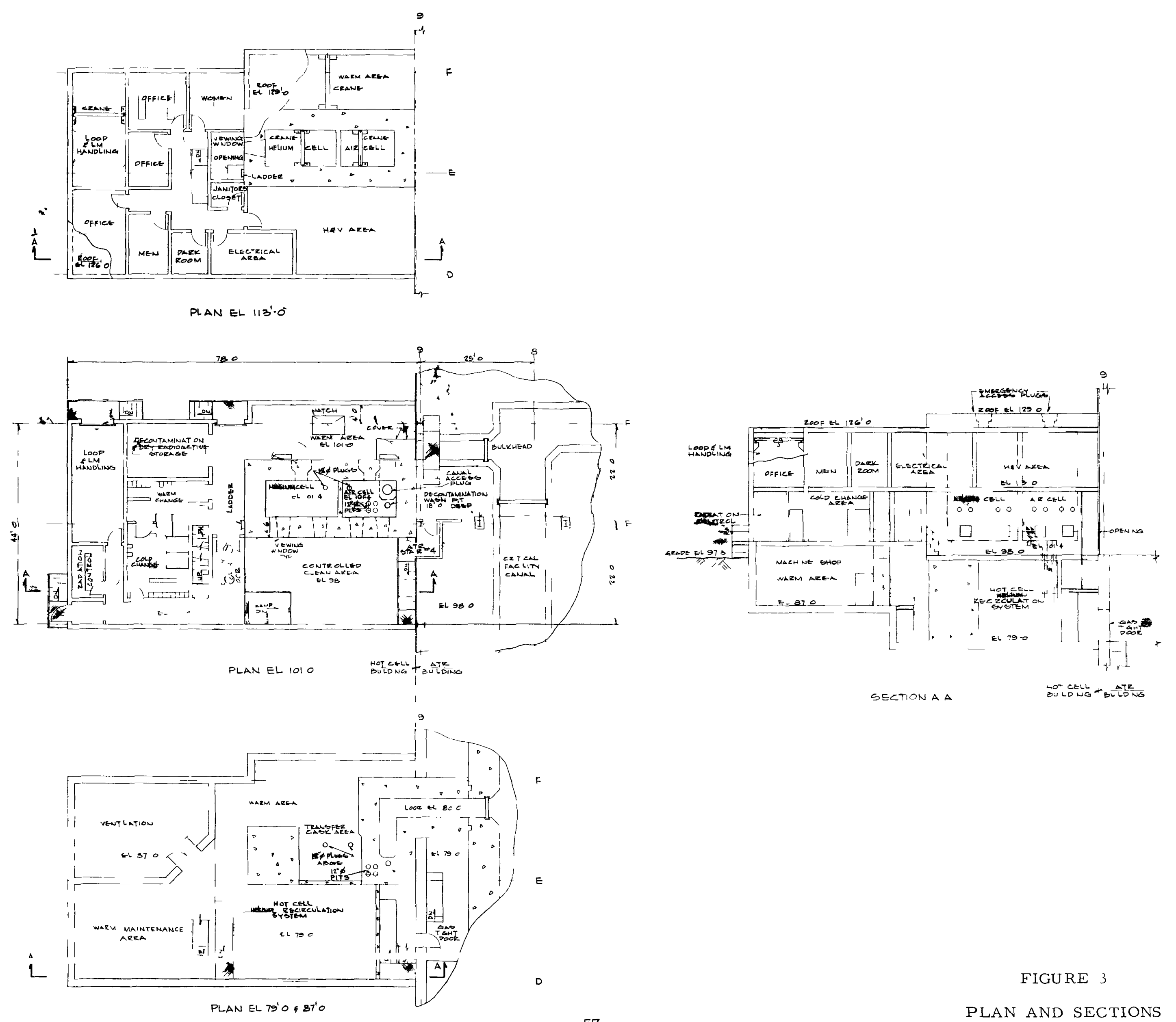

SEctionaA BO- EELL BATERE 


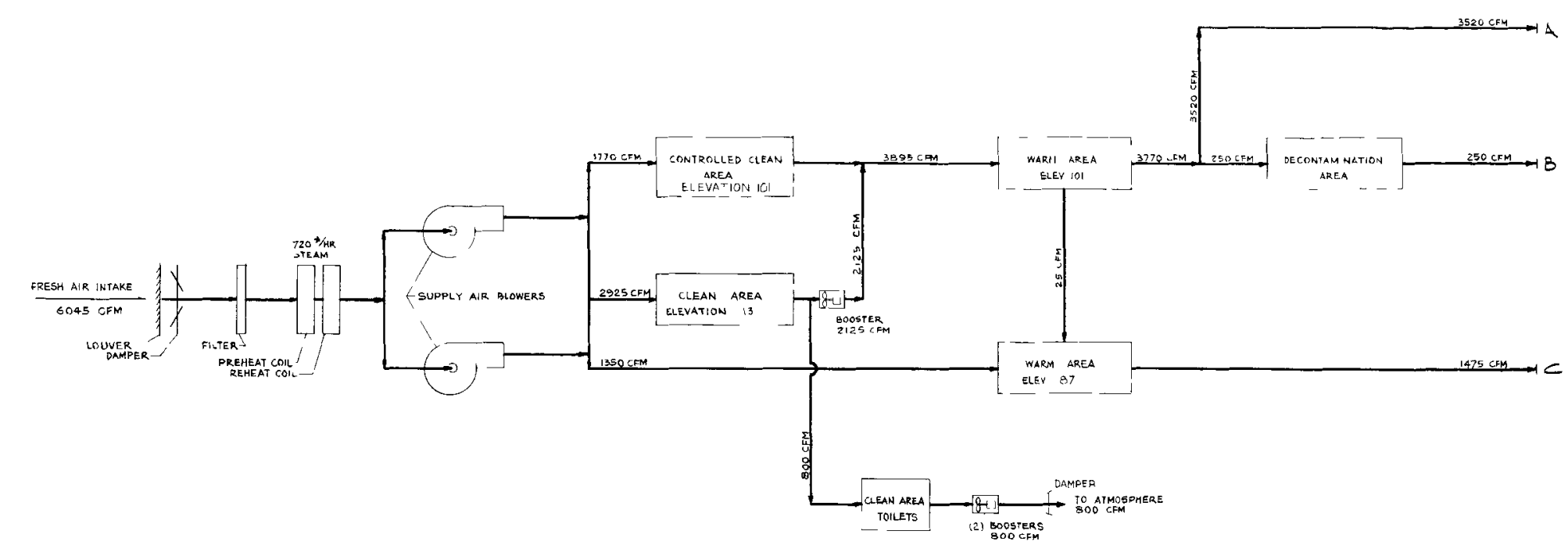

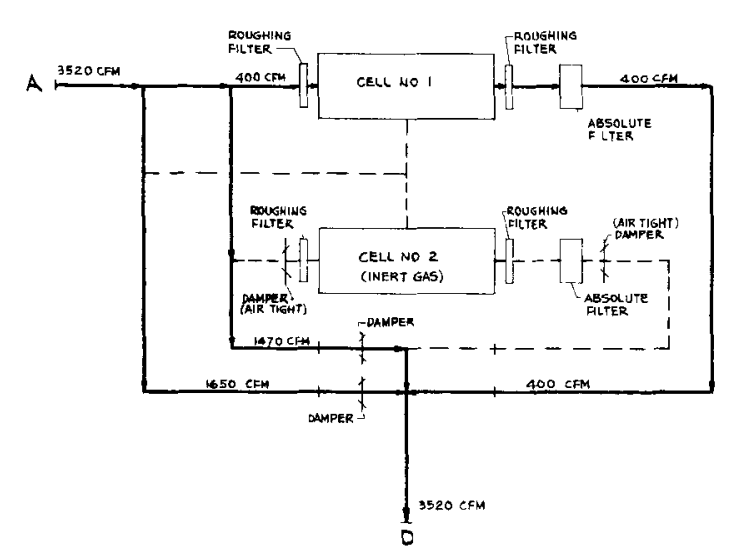

FOR NORMAL OPERATION (INERT GAS)

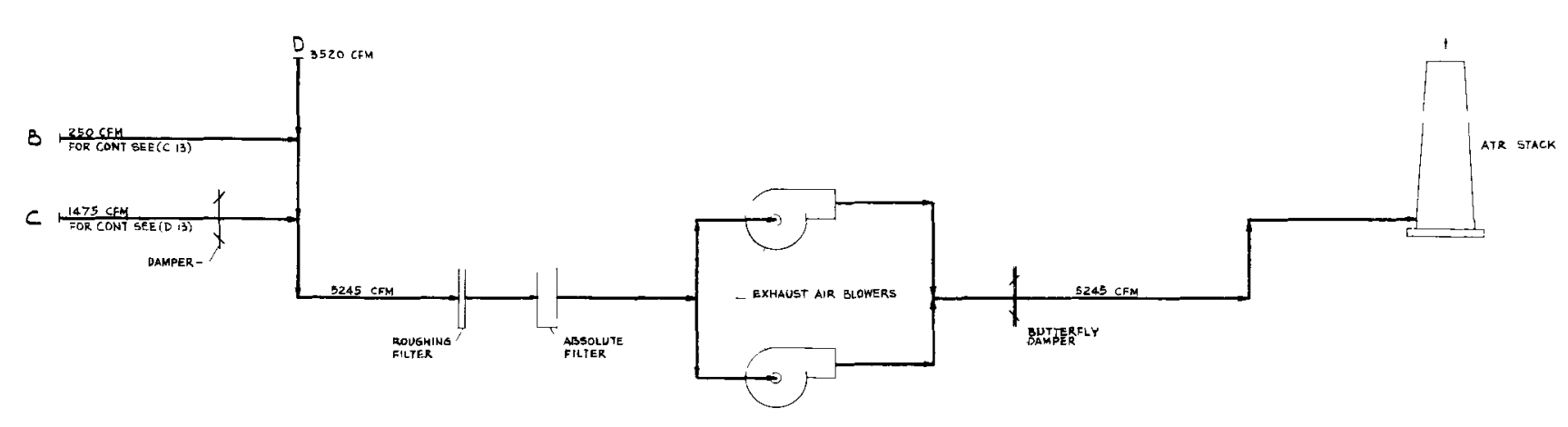

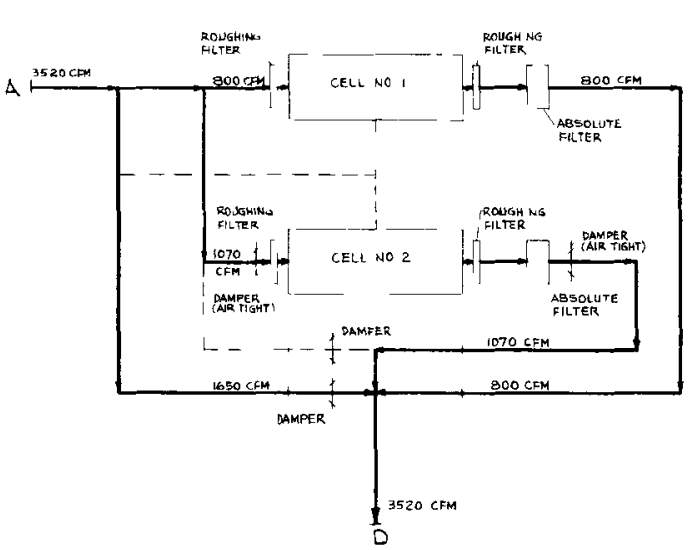

FOR EMERGENCY OPERATION (AIR)

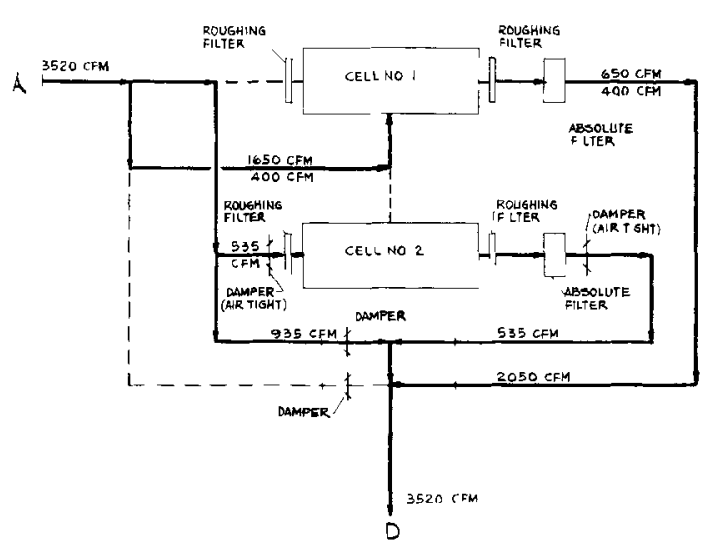

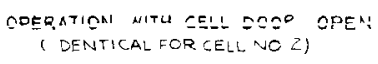

NOTE

Fivũa

HOT CELL FACILITY

VENTILATION SYSTEM 


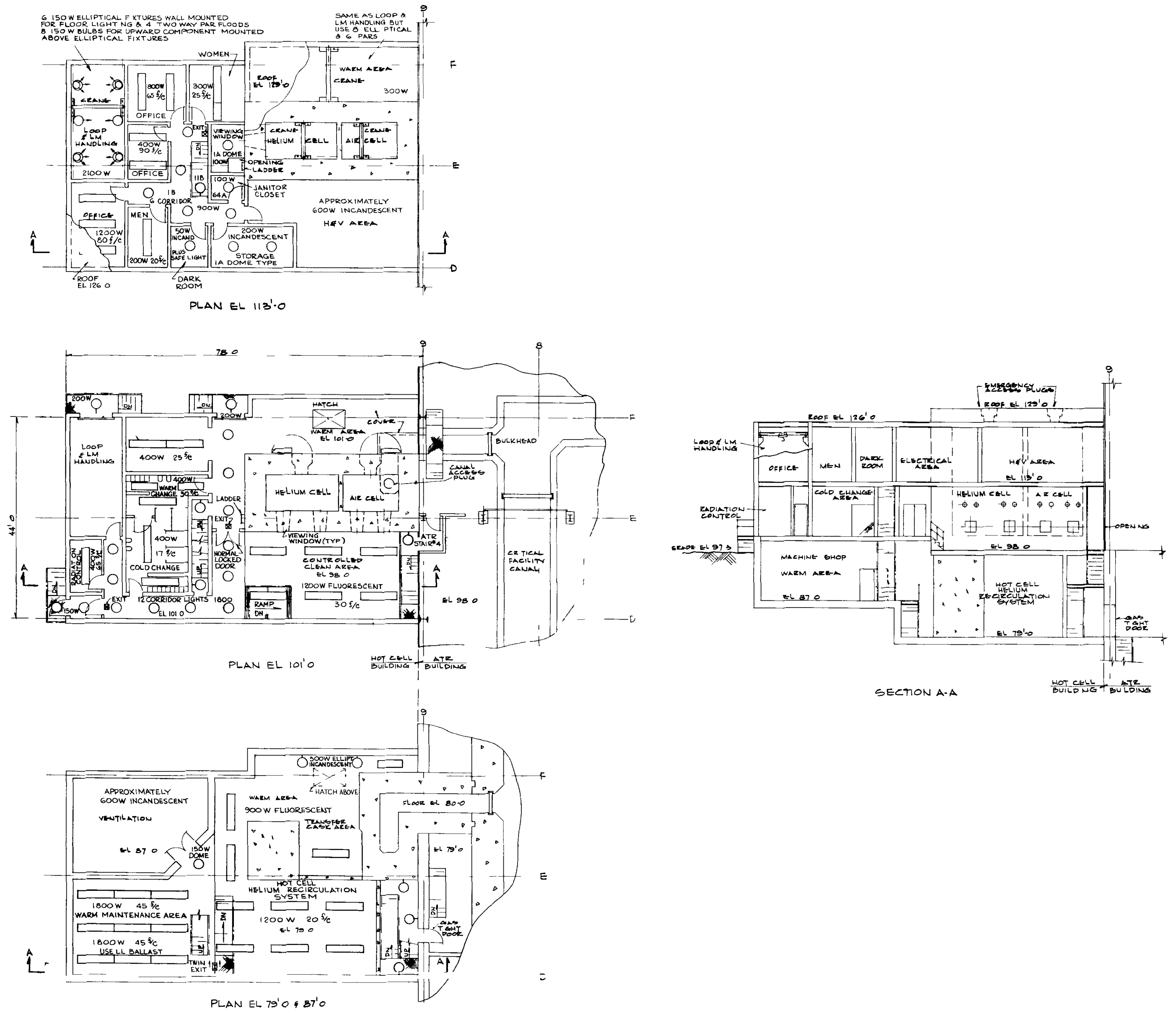

FIGŨス

HOT CELL FACILITY LIGHTING 


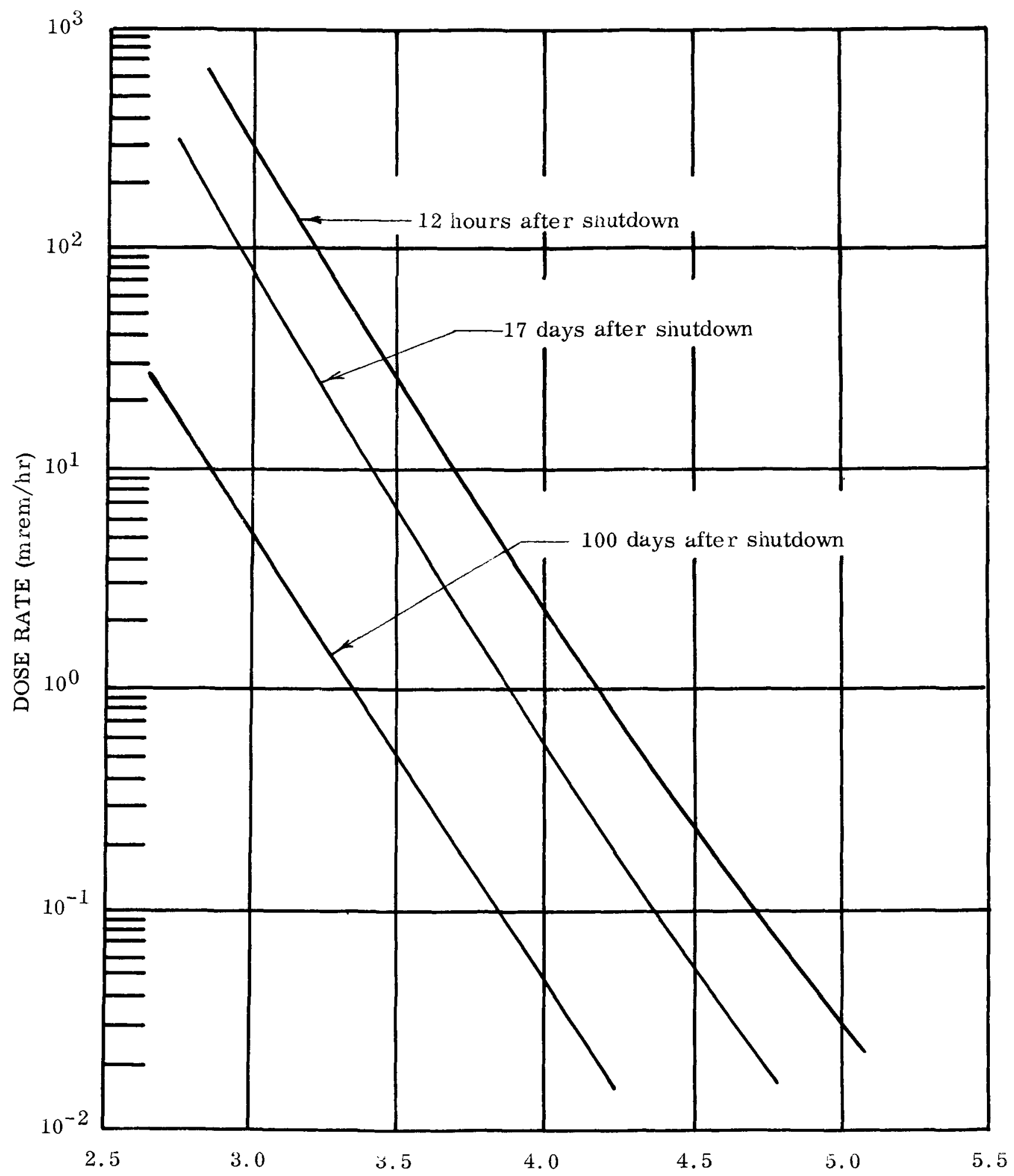

MAGNETITE CONCRETE THICKNESS (FEET)

FIGURE 7

ATR - HOT CELL FACILITY

FISSION PRODUCT DOSE RATE*

VS.

* From a Total of
(2) Fast and
(2) Thermal Flux Loops

MAGNETITE CONCRETE THICKNESS ( $3.55 \mathrm{G} / \mathrm{CC}$ )

Specimen Power - Fast - $150 \mathrm{Kw}$

- 61 - Specimen Power - Thermal - $1500 \mathrm{Kw}$ 


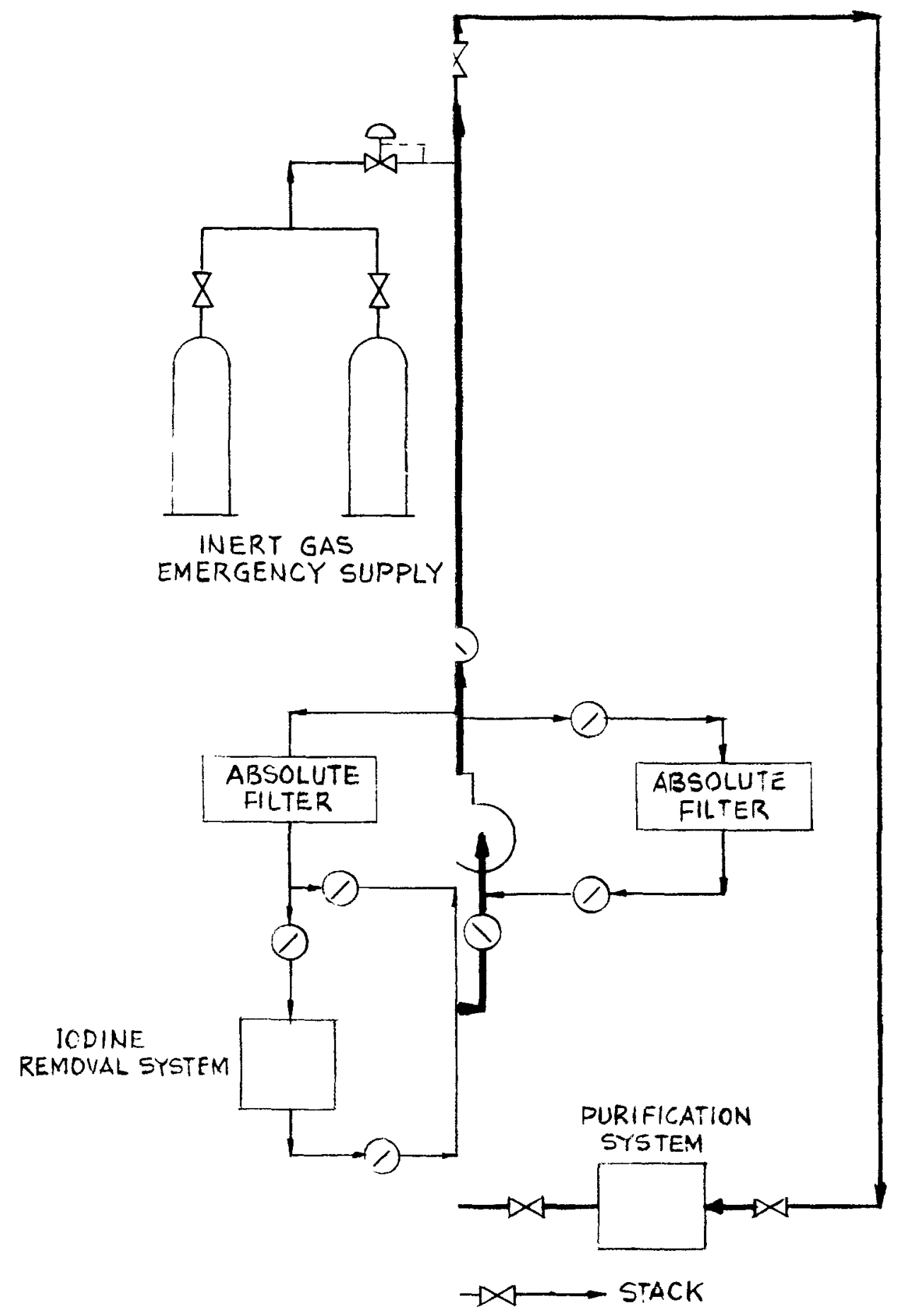

FTrTIRF: ?

INERT GAS

MAIN CIRCULATING SYSTEM 


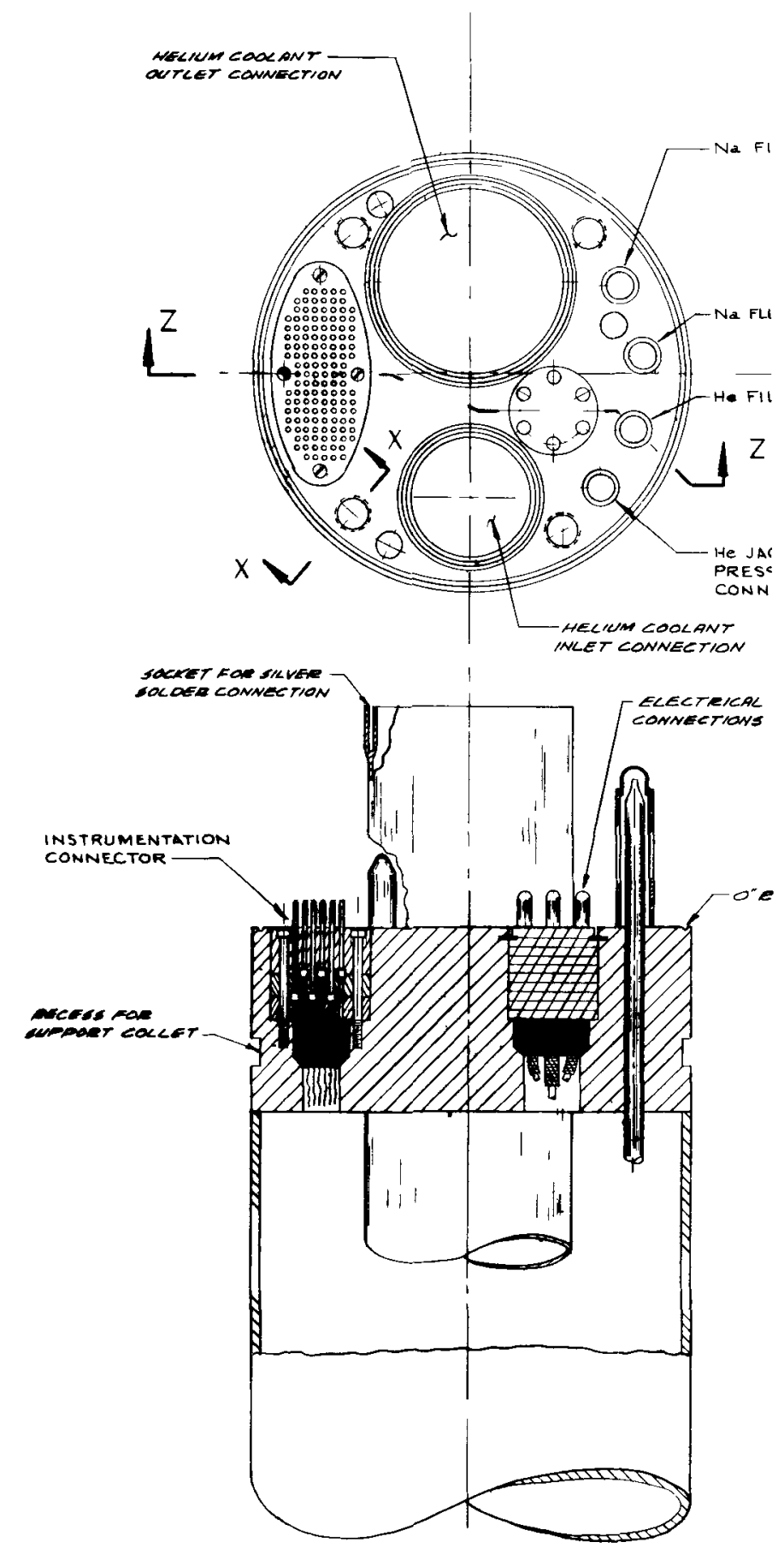

SECTION Z-Z

PACKAGE LOOP 

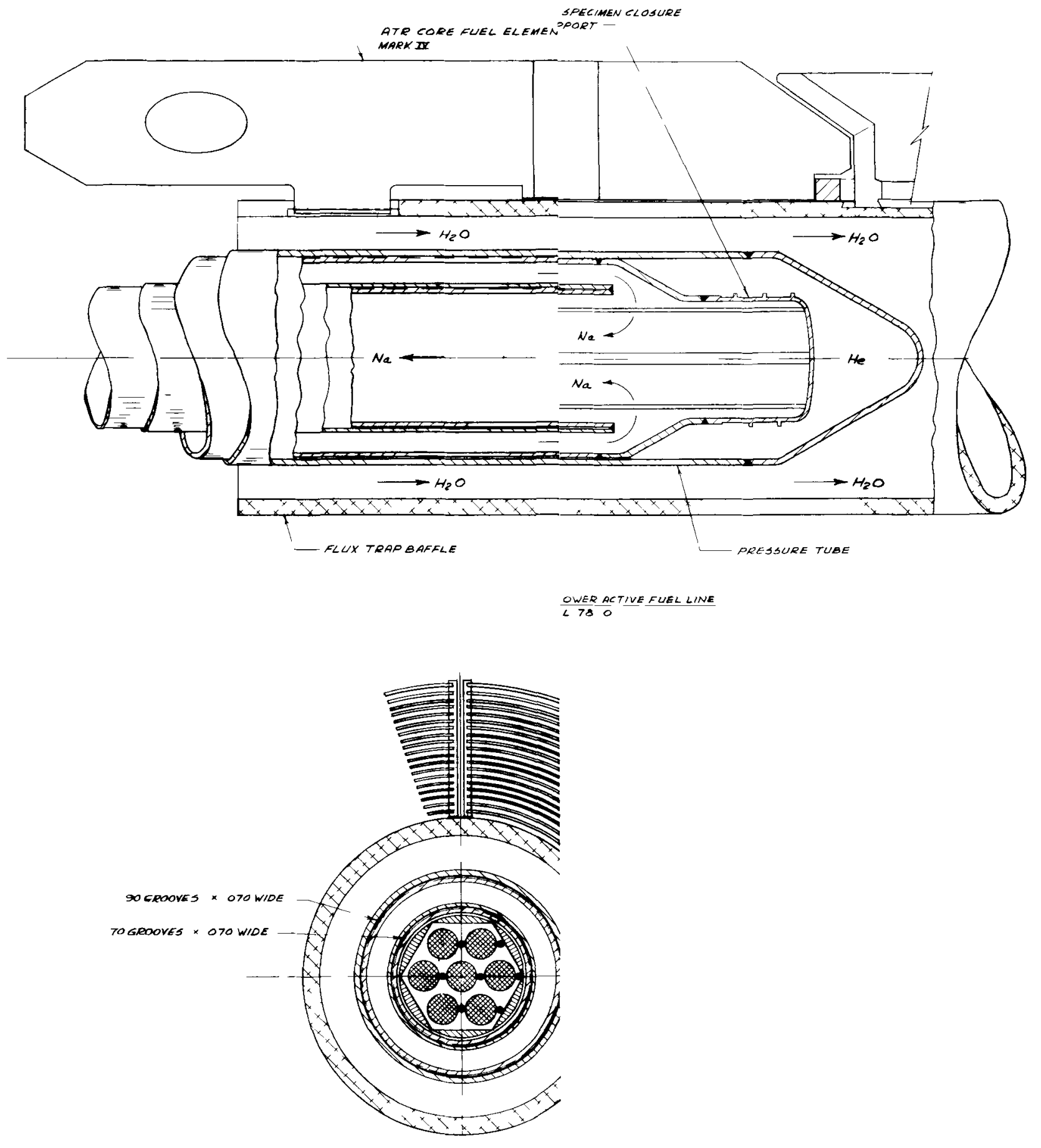

SECTION Z Z Z

FIGURE 11

L FLUX LOOP IN-CORE SECTION 


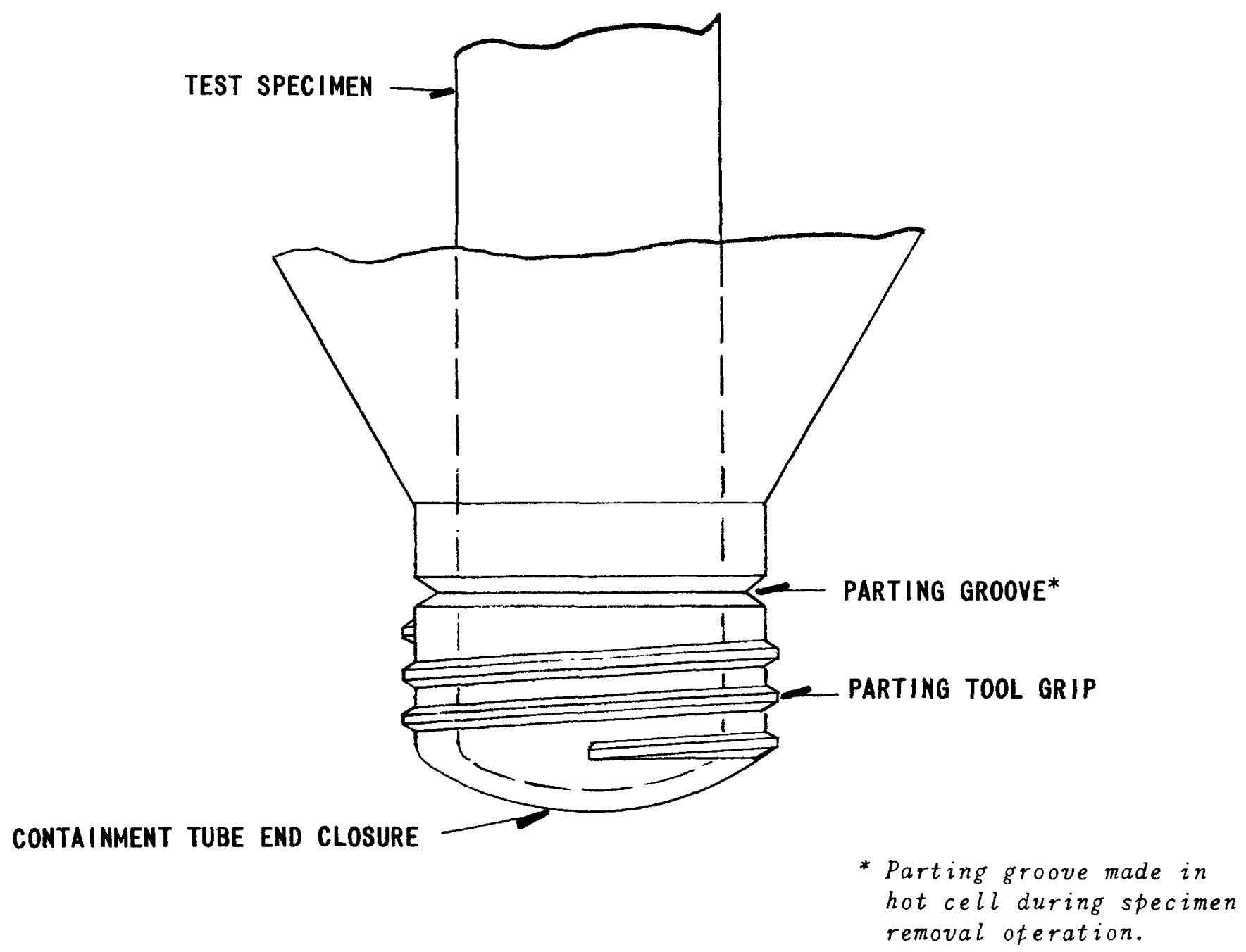

FIGURE 12

CONTAINMENT TUBE END CLOSURE 

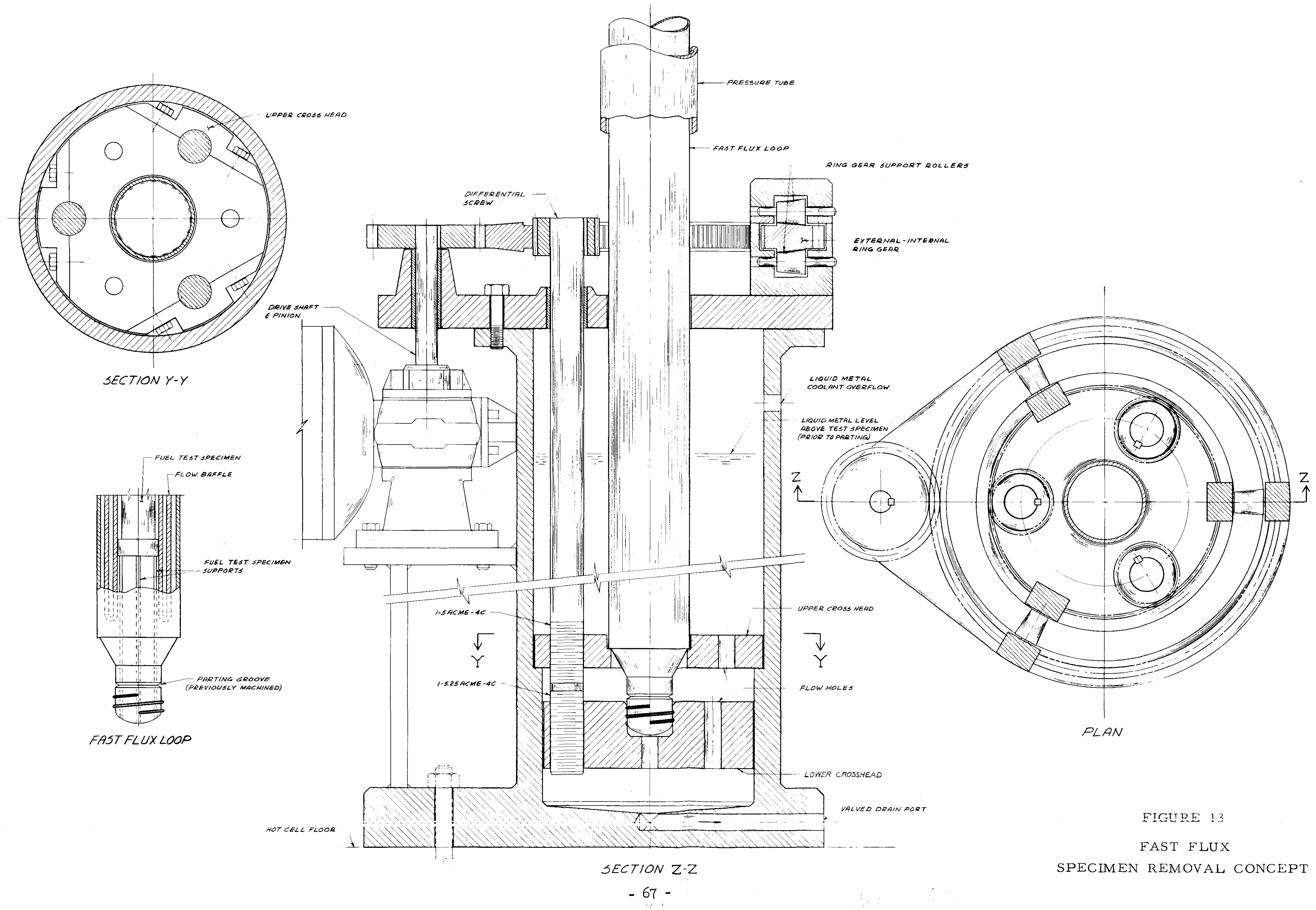
SPECIMEN REMOVAL CONCEPT 


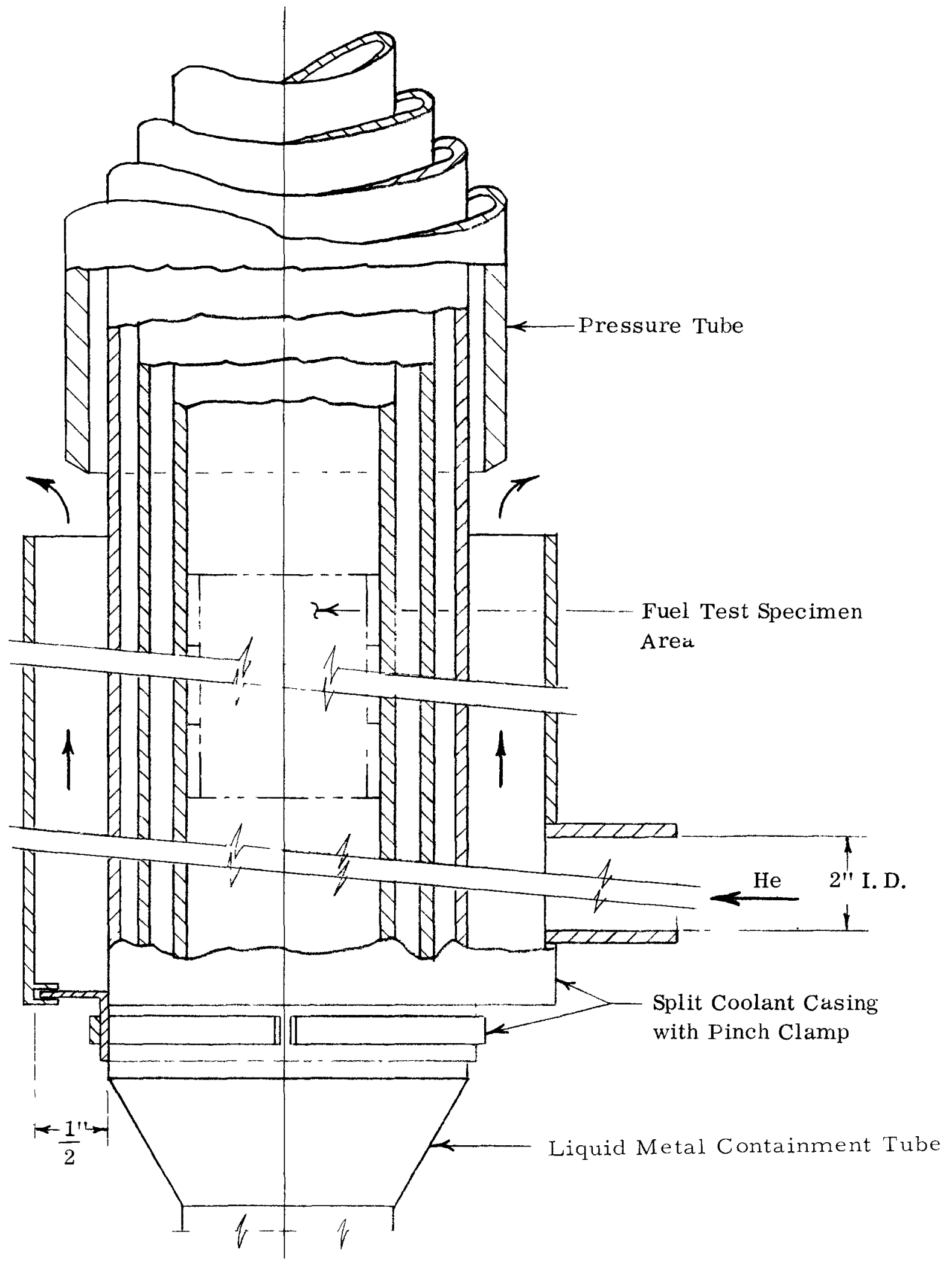

FIGURE 14

LIQUID METAL

PACKAGE LOOPS 

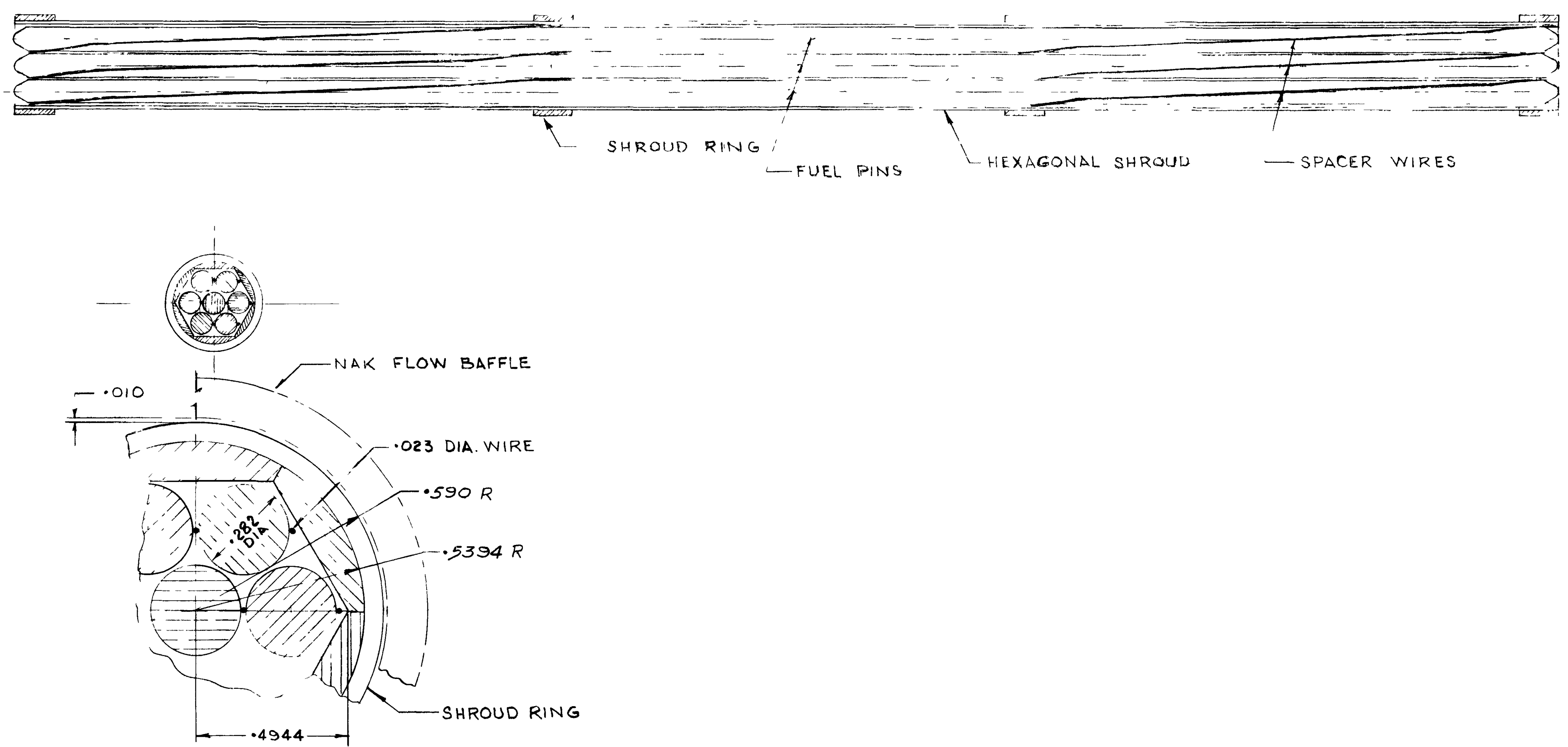

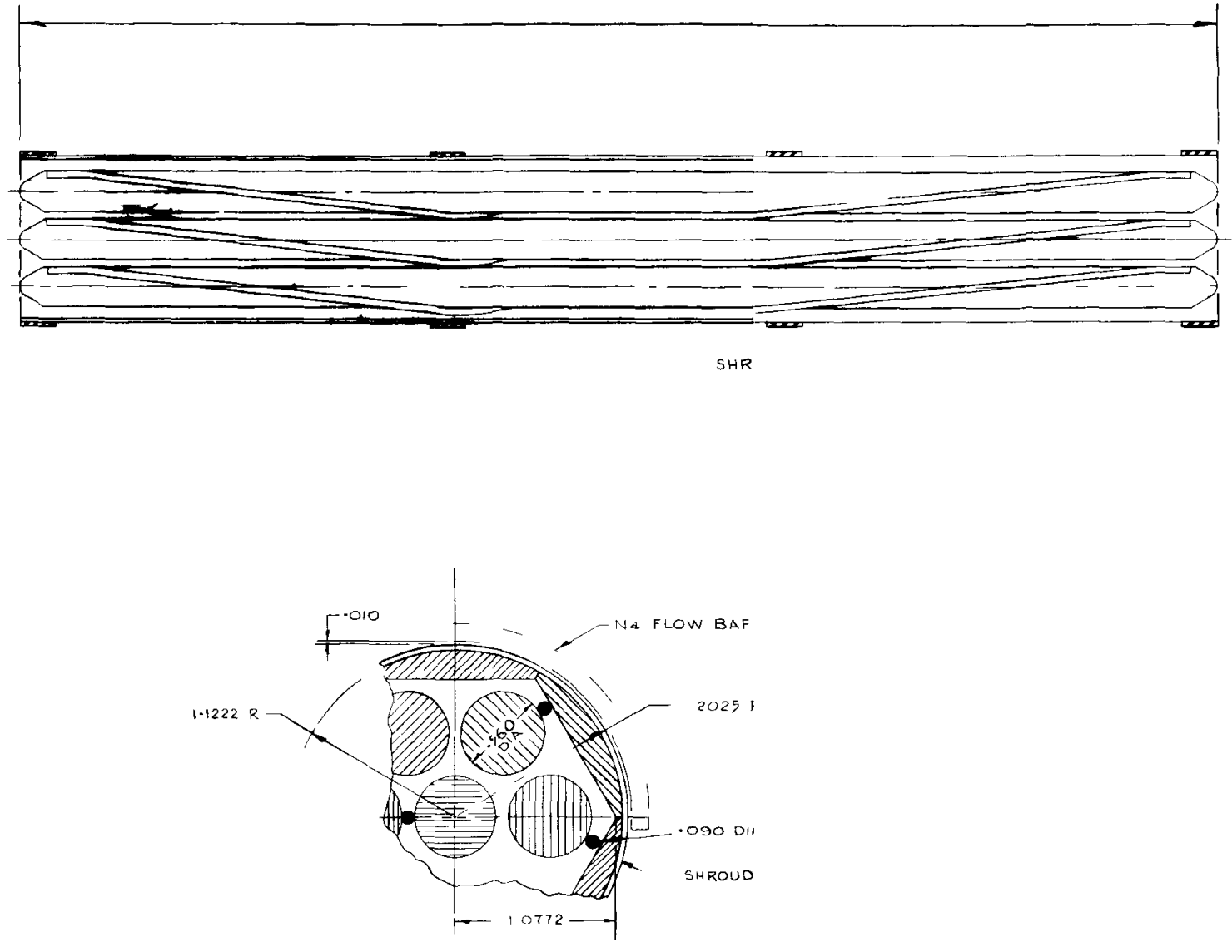

SCALE - $2 \times$ SIZE

FIGURE 16

JX REFERENCE TEST SPECIMEN 


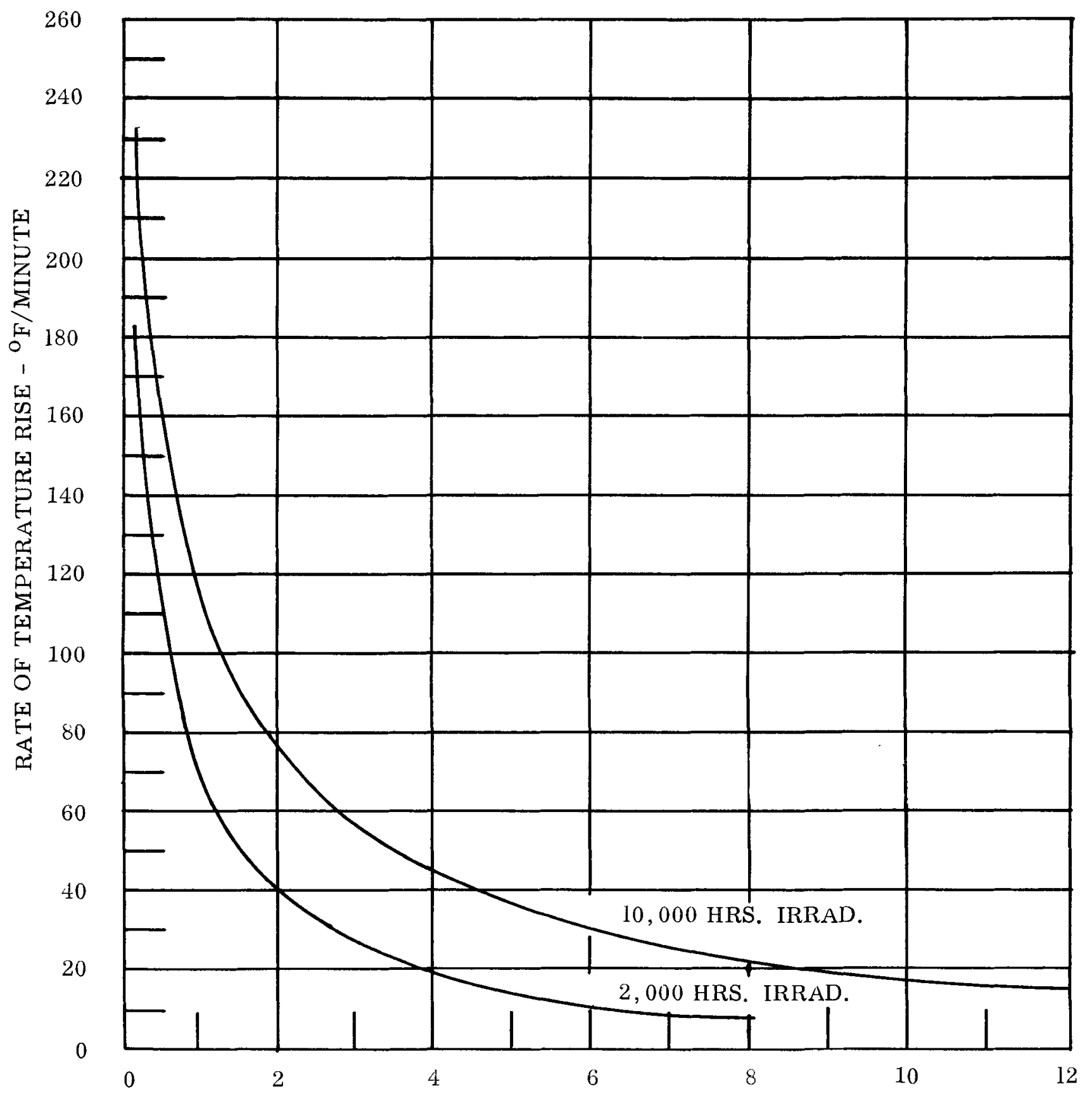

DECAY TIME - MONTHS 


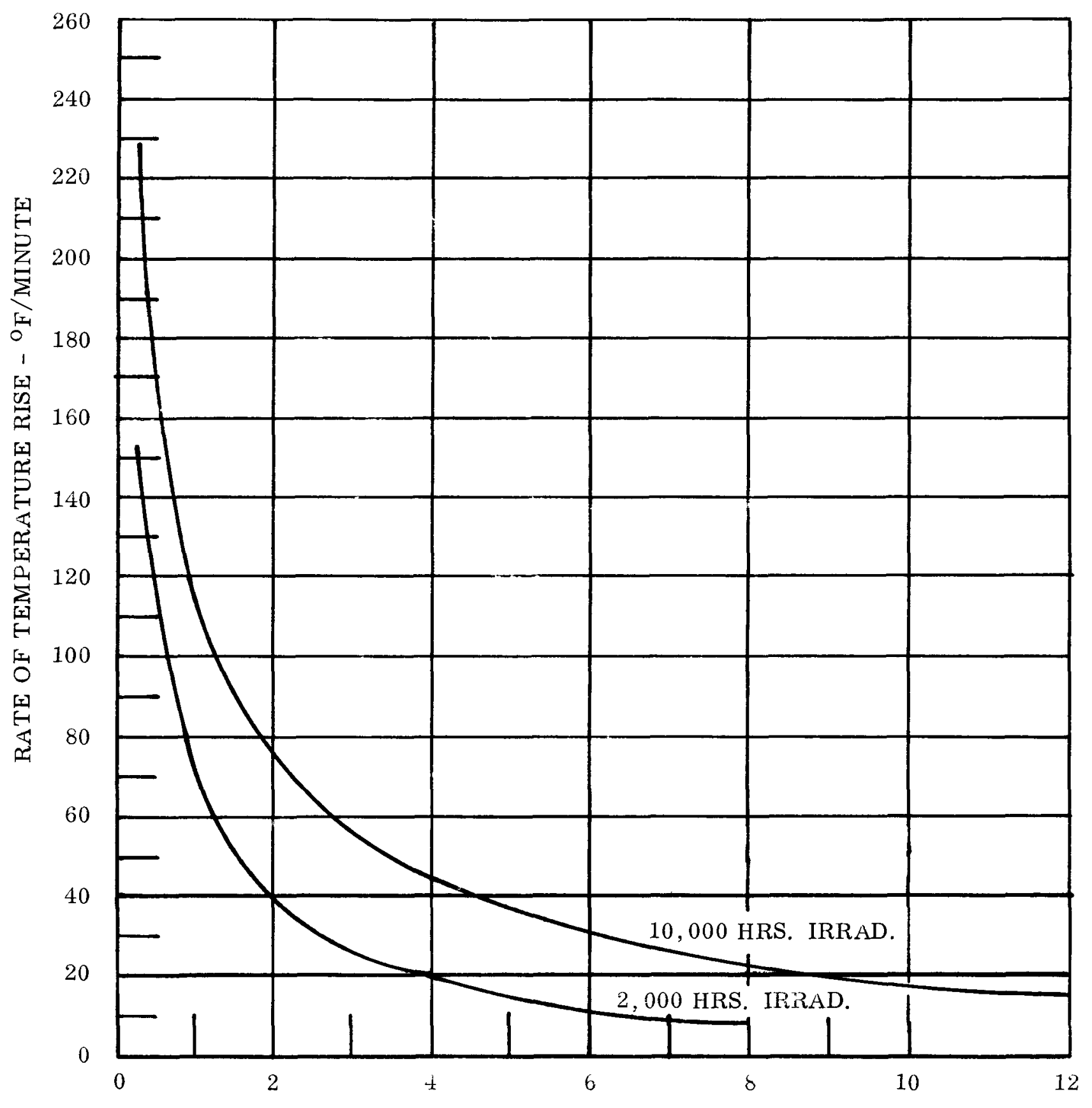

DECAY TIME - MONTHS 


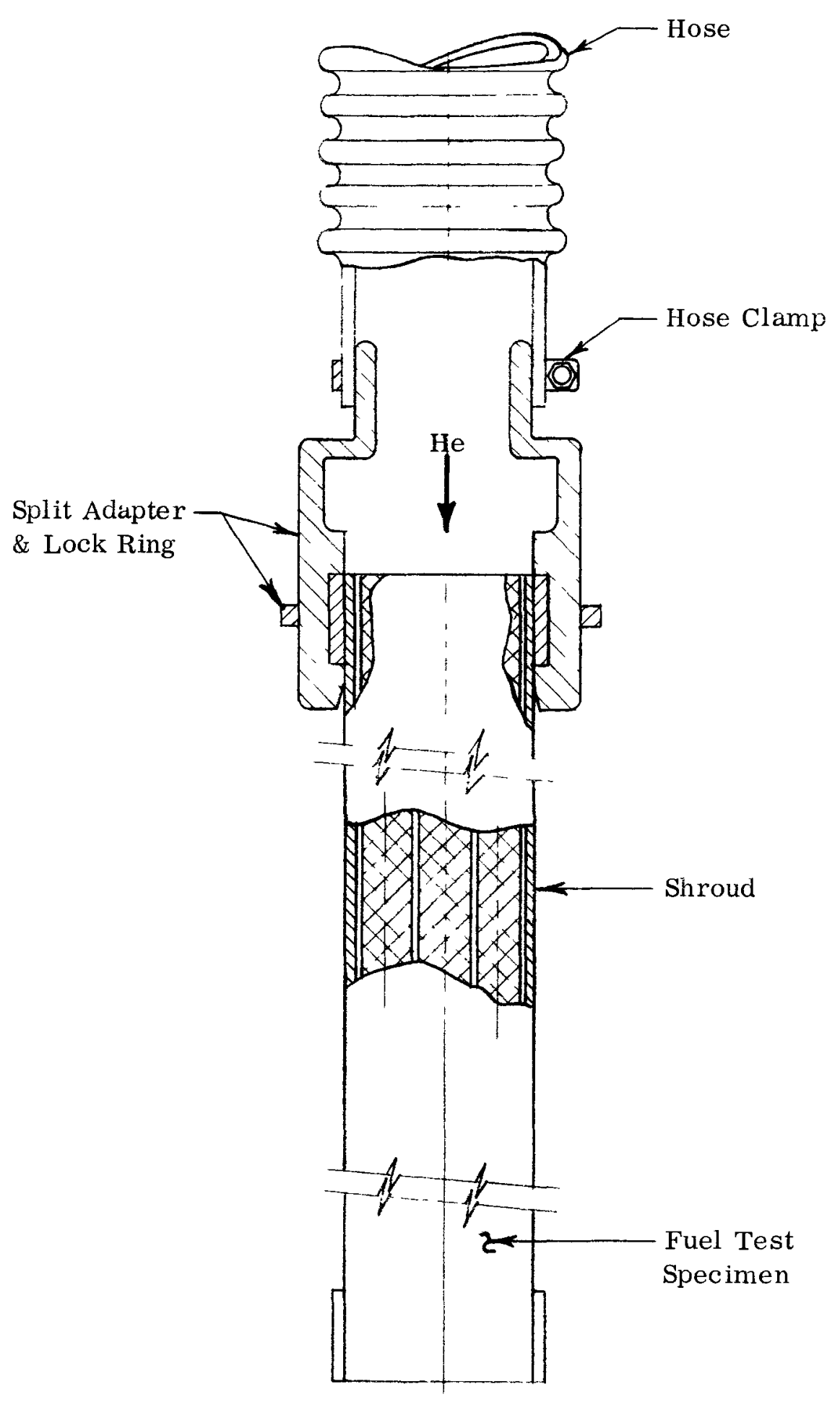

HELIUM COOLANT ADAPTER

FTCTPE 19

SPECIMEN COOLING 


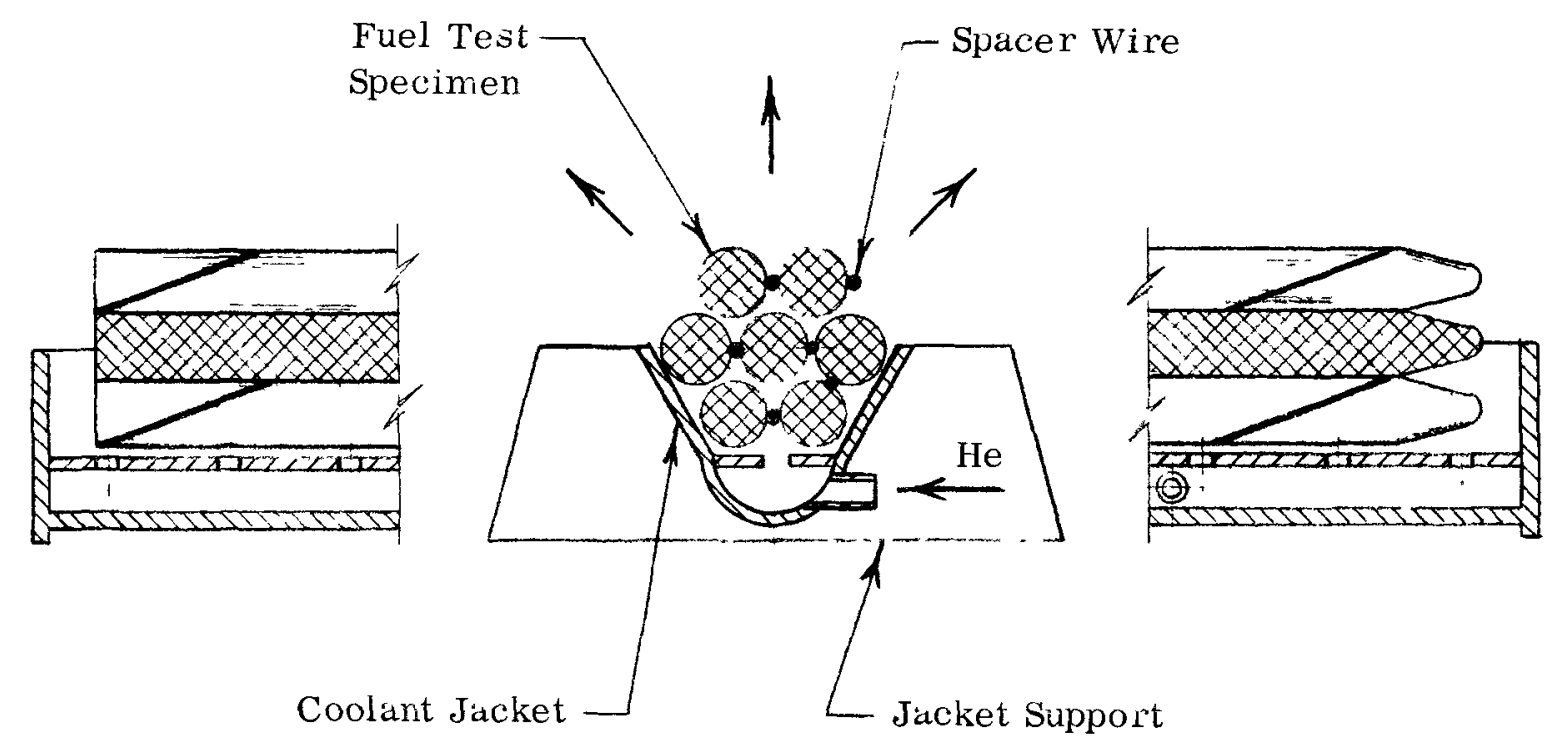




\section{PART II}

SUMMARY REPORT OF DESIGN CRITERIA FOR THE

LIQUID METAL PACKAGE LOOPS HANDLING SYSTEM AT THE ADVANCED TEST REACTOR 
$$
\text { . }
$$ 


\section{INTRODUCTION}

An important consideration in the feasibility of using the Liquid Metal Package Loops in the Advanced Test Reactor is the ability to install and remove the loops from the reactor within the scheduled reactor shutdown time. The handling procedures presented in this document summarizes the work which had been performed in meeting this criterion prior to the termination of the work on the package loop concept.

The procedures have been developed on the basis of the reference designs of the Fast and Thermal Flux Loops as presented in IDO 24041 "Design of Criteria for a Fast Flux Liquid Metal Loop in the Advanced Test Reactor," and IDO 24042 "Summery Report of Design Criteria for a Thermal Flux Liquid Metal Package Loop in the Advanced Test Reactor." 


\section{PURPOSE}

The purpose of this document is to present the design criteria and handling procedures required for the insertion and removal of the Liquid Metal Loops in the Advanced Test Reactor. 


\section{FACILITY DESCRIPTION}

\section{$3.1 \quad$ Reactor}

The ATR is a $250-\mathrm{MWt}$ water cooled test reactor providing experimental loop irradiation space for the AEC testing programs. The reactor is fueled with fully enriched $\mathrm{U}_{3} \mathrm{O}_{8}$ dispersed in and clad with an aluminum alloy. Bor on carbide is included in the fuel material as a burnable poison. The ATR core region consists of a 4-foot high vertical fuel annulus shaped in a serpentine fashion among and around nine flux trap areas in a $3 \times 3$ square array. The core region is surrounded by a metallic beryllium reflector.

The four flux trap positions on the corners of the square are referred to as inner fluxtrap positions (lobes) since they are nearly enclosed by the fuel annulus. Those on the sides of the square are exterior to the fuel annulus and are referred to as outer flux trap positions. The center position is referred to as the center flux trap. These flux traps will accommodate nine major test loops consisting of six pressurized water loops, two liquid metal cooled loops, and one gas cooled loop.

The Fast and Thermal Loop Facilities to be installed in the ATR (Reference 1) will consist of liquid metal cooled in-reactor packaged loops whose designs are based upon that of the Pratt \& Whitney Aircraft PW - 19 loop.

\section{$3.2 \underline{\text { Loop }}$}

The in-reactor sections of the package loop will consist of:

a) In-core package containing the test specimen and the self-contained liquid metal systems.

b) Loop Extension Tubes - support the in-core package in the ATR vessel, and provide passage for the helium secondary coolant supply and return piping, power and instrumentation leads from the in-reactor section outof-pile.

c) Thermal Neutron Filter - a double filter surrounding the in-core section of the Fast Flux Loop, which provides the desired Fast Flux Spectrum in the test specimen region.

d) Extended Core - located between the ATR core and the thermal neutron filter, maintaining sufficient reactivity and achieving suitable sample power for the desired irradiation test.

Detailed descriptions and design criteria for both loops are presented in References 2, 3 and 4. 


\subsection{Loop Location}

The in-core sections of the Fast and Thermal Flux Loops consisting of the in-core package and extension tube will be approximately 22 and 24 feet long assemblies (respectively) supported in vertical positions from the reactor top head as shown in Figure 21.

The test section area of the Fast Flux Loop will be located in the northeast $(40 \mathrm{mw})$ lobe, while the Thermal Flux Loop will be located in the east ( $50 \mathrm{mw}$ ) flux trap. A plan view of the ATR core and loop positions is shown in Figure 22. 


\section{RADIATION LEVELS}

\subsection{General}

Of particular importance to satisfactory operations of the ATR and the package loops will be the radiation produced by the loops during both reactor operation and shutdown periods.

The permissible radiation levels within the ATR Facility, as established in IDO 24040 (Reference 1), are presented in Table 13. These radiation levels have been used as the design criteria for establishing the loop shielding requirements and handling procedures.

The primary sources of after shutdown radiation from the package loops are gamma rays from induced activity of the liquid metal coolant and loop structural materials and from fission products resulting from a test specimen failure. With the loops in their normal operating and handling position (vertical) the liquid metal sump is the uppermost location of the coolant and in all cases the source of the controlling radiations.

Analyses of the radiation levels from both loops are presented in Appendixes $\mathrm{K}$ and $\mathrm{L}$ and are summarized in Sections 4.2 and 4.3.

\subsection{Fast Flux Loop}

During reactor operation the top of the Fast Flux Loop package section (Reference 2) will be covered with approximately 9 feet of water which provides adequate radiation shielding. However, for loop handling and certain reactor maintenance operations, the amount of water over the top of the loop will decrease. The water thicknesses over the top of the loop for the various operations are presented in Table 14. 
Table 13

ATR SHIELD DESIGN DOSE RATE CRITERIA

\section{Location}

Full-time occupancy areas

Outside reactor concrete shielding

Outside experiment loop cubicles

Inside experiment $\mathrm{H}_{2} \mathrm{O}$ loop cubicles

Motor area

Sub-pile room

Rod access room

Above storage canal and at floor level near parapet

Outside demineralizer vaults

Inside demineralizer vaults

Floor above heat exchangers

Inside sample areas

Maximum transient dose rate during refueling

Reactor area - 1st floor

Reactor vessel top head
Design Level During

Full Power Operation

(mrem/hr)

0.25

2.5

2.5

2.5 from adjacent operating cubicles; 5.0 from reactor and primary piping

$$
1.0
$$

No access

$$
7.5
$$

1.0

7.5

No access

1.0

7.5 total from reactor, cubicles, and fuel in storage canal; 25 from sample
Design Level

After Shutdown

(mrem/hr)

0.25

2.5

2.5

5.0 (loops not operating)

1.0

12.5 one hour after shutdown

\section{5}

1.0

7.5

7.5 from adjacent vault after flushing resin in vault

1.0

7.5

50.0

1.0

1.0

2.5
1.0 from core with head removed after flushing 
WATER THICKNESSES ABOVE THE TOP OF THE FAST FLUX LOOP

\author{
Operation \\ Water Thickness - Feet \\ 1 - Reactor Shutdown-Loop in \\ Normal Position \\ 9 \\ 2 - Capsule Experiment Removal \\ 2 al \\ 3 - In-Reactor Loop Movement \\ 1 \\ 4 - Parting of Loop Extension Tube \\ and In-Core Section \\ $-1 \underline{b /}$ \\ 5 - Loop in Canal \\ 8

\begin{abstract}
a) Water level lowered 7 feet to elevation 93 feet.
b/ Top of in-core section raised above reactor top head.
\end{abstract}

The radiation levels at the top of the water level are presented in Figure 23 for a loop with a normal test specimen and in Figure 24 for a loop with a failed test specimen. The radiation levels presented have been based on $100 \%$ of the NaK activity in the loop sump which is the worst possible case. An analysis of the PW-19 loop by Pratt \& Whitney Aircraft indicated that only $12.4 \%$ of the liquid metal activity would be in the sump. It should be noted that the radiation levels given in Figures 23 and 24 do not account for the 8 -inch thick steel plate in the reactor vessel head with its associated attenuation factor of approximately 200 . With all holes in the top head closed the highest exposure to personnel which would occur during the parting operation one hour after shutdown, would be $10 \mathrm{mrem} / \mathrm{hr}$ through the steel plate and $1.3 \times 10^{3} \mathrm{mrem} / \mathrm{hr}$ streaming through the loop. A 15 inch thick lead plug located in the top of the in-core section will reduce the streaming through a loop with a ruptured test specimen, which is the worst case, to $0.25 \mathrm{mrem} / \mathrm{hr}$.

During the capsule experiment removal operation the refueling ports will be opened and the water level in the reactor lowered 7 feet. However, the dose rate of $10^{3} \mathrm{mrem} / \mathrm{hr}$ shown in Figure 24 for one hour after shutdown is at the surface of the reactor water and not at the top head. The dose rate at the latter position has not been calculated to date. Another area of consideration during capsule experiment removal is the capsule handling trench. The dose rate within this area, from the Fast Flux Loop, was not calculated since the higher radiation levels from the Thermal Flux Loop will be the controlling design basis. 


\subsection{Thermal Flux Loop}

During reactor operation the top of the Thermal Flux Loop in-core section will be covered with approximately 7 feet of water. The amounts of water over the loop, which will vary for loop handling and certain reactor maintenance operations, are presented in Table 15.

\section{Table 15}

\section{WATER THICKNESS ABOVE THE TOP OF THE THERMAL FLUX LOOP}

\section{Operation}

1 - Reactor Shutdown-Loop in

Normal Position

2 - Capsule Experiment Removal

3 - In-Reactor Loop Movement

4 - Parting of Loop Extension Tube a/ and In-Core Section

5 - Loop in Canal

\section{Water Thickness - Feet}

7

0 a/

1

$-1 \underline{b} /$

6

a/ Water level lowered 7 feet to elevation 93 feet.

b/ Top of in-core section raised above reactor top head.

Preliminary shielding calculations were made on the conceptual design of the Thermal Flux Loop (Reference 4) and are presented in Appendix L. A summary of some of the results is shown in Table 16 .

The data presented in Table 16 has been based on $100 \%$ of the $\mathrm{Na}^{24}$ activity being in the liquid metal sump and is therefore conservative. As noted in the previous section the actual amount of activity in the sump will be between $12.4 \%$ and $100 \%$. 
Table 16

THERMAL FLUX LOOP RADIATION LEVELS a/

\begin{tabular}{|c|c|c|c|c|}
\hline \multirow{2}{*}{ Operation } & \multirow{2}{*}{$\begin{array}{c}\text { Test } \\
\text { Specimen } \\
\end{array}$} & \multirow{2}{*}{$\begin{array}{l}\text { Shutdown } \\
\text { Time } \\
\end{array}$} & \multicolumn{2}{|c|}{ Radiation } \\
\hline & & & Level & Location \\
\hline $\begin{array}{l}\text { Ca:sule Experiment } \\
\text { Removal b/, cl }\end{array}$ & Normal & $\begin{array}{l}1 \text { day } \\
3 \text { days } \\
1 \text { hour } \\
1 \text { hour }\end{array}$ & $\begin{array}{l}70 \mathrm{R} / \mathrm{hr} \\
8 \mathrm{R} / \mathrm{hr} \\
13.5 \mathrm{rem} / \mathrm{hr} \\
513 \mathrm{mrem} / \mathrm{hr}\end{array}$ & $\begin{array}{l}\text { Surface of } W \\
\text { Surface of } W \\
\text { Top Head } \\
\text { Capsule Tren }\end{array}$ \\
\hline $\begin{array}{l}\text { Loup Movement } \\
\text { In - Reactor }\end{array}$ & $\begin{array}{l}\text { Ruptured } \\
\text { Cladding }\end{array}$ & $\begin{array}{l}3 \text { days } \\
3 \text { days }\end{array}$ & $\begin{array}{r}1.8 \mathrm{rem} / \mathrm{hr} \text { b/ } \\
108 \mathrm{mrem} / \mathrm{hr} \underline{b} /\end{array}$ & $\begin{array}{l}\text { Top Head } \\
\text { Top Head }\end{array}$ \\
\hline $\begin{array}{l}\text { Pajting of Extension } \\
\text { Tuk e and In-Core } \\
\text { Section }\end{array}$ & $\begin{array}{l}\text { Ruptured } \\
\text { Cladding }\end{array}$ & 3 days & $152 \mathrm{mrem} / \mathrm{hr} \mathrm{b} /$ & Top Head \\
\hline \multicolumn{5}{|l|}{ Notes: } \\
\hline \multicolumn{5}{|c|}{$\begin{array}{l}\text { a/ Loop contains } 3-1 / 2 \text { inches of tu } \\
\text { b/ } 100 \% \mathrm{Na}^{24} \text { activity in the sump. }\end{array}$} \\
\hline
\end{tabular}




\section{REACTOR CRITERIA}

\subsection{General}

The after shutdown dose rates in two areas of the ATR Facility resulting from Thermal Flux Loop radiation are above the acceptable limits. As shown in Table 16 the areas of unacceptable radiation levels are:

a) The capsule access trench

b) The inside of the reactor vessel (same water level as capsule experiment removal operation)

\subsection{Capsule Access Trench}

The after shutdown radiation levels in the capsule access trench, will be approximately $513 \mathrm{mrem} / \mathrm{hr}$ l hour after reactor shutdown (Table 16)。

In an effort to lower the radiation to a permissible level, calculations were performed with the inside of the loop sump wall shielded with $1 / 2$ inch thick tungsten. The calculations showed that the use of internal shielding to reduce the radiation levels would not be satisfactory. As described in detail in Appendix $L$, the use of internal shielding tends to increase rather than decrease the radiation levels within the trench.

Since the physical size and configuration of the Thermal Flux Loop prohibits the use of external shielding, the criterion has been established that the radiation shielding shall be placed within the capsule access trench. The size and location of the shielding shall be determined during the Thermal Flux Loop Title I phase.

\subsection{Reactor Vessel Entry}

During the life span of the reactor, personnel entry into the reactor vessel will be required for welding, inspection and other maintenance operations. The entry will require that the water level be lowered to 10 to 11 feet above the top of the core. With the water at these levels, the radiation level at the surface will range from $8 \mathrm{R} / \mathrm{hr}$ to $320 \mathrm{R} / \mathrm{hr}$ as shown in Table 17 . 
Table 17

WATER SURFACE RADIATION LEVELS FROM THE THERMAL FLUX LOOP

Water Leve: - Feet

Above Top of Core

10

10

11

11
Shutdown

Time

1 day

3 days

1 day

3 days
Radiation Level at the Surface of the Water

$320 \mathrm{R} / \mathrm{hr}$

$35 \mathrm{R} / \mathrm{hr}$

$70 \mathrm{R} / \mathrm{hr}$

$8 \mathrm{R} / \mathrm{hr}$

Because of the extremely high dose rates that would be encountered, no personnel entry into the reactor vessel shall be permitted until the Thermal Flux Loop is removed from the vessel. 


\section{LOOP HANDLING}

\subsection{General}

The handling of the Fast and Thermal Flux Loops within the ATR Facility consists of:
a) Transporting the loops from the Hot Cell Facility to the reactor.
b) Inserting the loops in the reactor.
c) Removing the loops from the reactor.
d) Transporting the loops to the Hot Cell Facility.

The handling procedures have been based on (a), the USAEC requirement that the loops be transported through the canal (Reference 5), (b), the radiation levels from the irradiated loops as presented in Seciion 4 and $(c)$ the test specimen requirements.

To date, the conceptual handling procedures for the liquid metal loops have been developed for the Fast Flux Loop only. The handling procedures and required equipment are discussed in the following sections and presented in detail in Appendix $M$. The handling procedures described will be generally applicable to the Thermal Flux Loop also. Hqwever, the procedures will require modification to provide power and instrumentation leads to the loop during all handling operations.

\subsection{Loop Removal}

The procedures for removing the Fast and Thermal Flux Loops have been designed for remote operation as required by the radiation levels from the loops. Removal from the reactor will be obtained by use of the drop tube which is located at the north side of the reactor vessel (Figures 21 and 22).

The removal of the loops from the reactor will entail raising the loop until the top of the in-core section is above the reactor top head, removing the extension tube and replacing it with a short handling extension, lowering the loop below the top head, and traversing it to the drop tube through which the loop passes down into the canal thimble.

The equipment required for loop removal will consist of:
a) ATR 2-ton crane
b) Shielded loop transfer tool for traversing the loop
c) Shielded loop handling sling
d) Long handled tools
e) Shielded window for a refueling port
f) Canal thimble 
The procedures for loop removal and the handling equipment are presented in detail in Appendix $M$ and shown conceptually in Figures $25 \mathrm{~A}, \mathrm{~B}$ and $\mathrm{C}$. The conceptual design of the shielded loop-transfer tool is illustrated in Figure 26.

The decay periods, for loop handling in different environments, that will be required to prevent overheating the test specimens are shown in Tables 18 and 19. As previously noted the decay times are only approximations and are presented to serve as guides in determining loop handling procedures. A detailed discussion of the decay times required for loop handling is presented in Appendixes $E$ and $F$.

Table 18

\section{FAST FLUX LOOP DECAY PERIODS}

\begin{tabular}{lcccc}
$\begin{array}{c}\text { NaK } \\
\text { Pump }\end{array}$ & $\begin{array}{c}\text { Helium } \\
\text { Flow }\end{array}$ & Loop Position & $\begin{array}{l}\text { Shutdown } \\
\text { Time a/ }\end{array}$ \\
\cline { 1 - 1 } On & Off & Loop in-core, full flux trap water flow & $1 / 2$ hour \\
Off & Off & Loop in-core, full flux trap water flow & 5 weeks \\
On & Off & Loop in stagnant 100 F water b/ & $1 / 4$ hour \\
Off & Off & Loop in stagnant 100 F water b/ & 4 days
\end{tabular}

Notes:

af Total elapsed time before loop environment is tolerable.

b/ Loop removed from in-core position. 
Table 19

THERMAL FLUX LOOP DECAY PERIODS

\begin{tabular}{|c|c|c|c|c|}
\hline $\begin{array}{c}\text { Sodium Pump a/ } \\
\text { Power, Kw } \\
\end{array}$ & $\begin{array}{c}\text { Sodium } \\
\text { Temp. F }\end{array}$ & $\begin{array}{l}\text { Helium } \\
\text { Flow } \\
\end{array}$ & Loop Position & $\begin{array}{c}\text { Shutdown } \\
\text { Time } \\
\end{array}$ \\
\hline 12.0 & $\begin{array}{c}975 \\
\text { (Max.) }\end{array}$ & Off & $\begin{array}{l}\text { Loop In-Core, Full } \\
\text { Reactor Flow }\end{array}$ & $10 \mathrm{sec}$ \\
\hline 12.0 & 250. & Off & $\begin{array}{l}\text { Loop In-Core, Full } \\
\text { Reactor Water } \\
\text { Flow }\end{array}$ & 2 weeks b/ \\
\hline 12.0 & $\begin{array}{c}975 \\
\text { (Max.) }\end{array}$ & Off & $\begin{array}{l}\text { Loop in Stagnant } \\
100 \text { F Water }\end{array}$ & $10 \mathrm{sec}$ \\
\hline 12.0 & 250 & Off & $\begin{array}{l}\text { Loop in Stagnant } \\
100 \mathrm{~F} \mathrm{Water}\end{array}$ & 8 days b/ \\
\hline 12.0 & $\begin{array}{c}250 \\
\text { (Min.) }\end{array}$ & Off & $\begin{array}{l}\text { Loop in Stagnant } \\
100 \mathrm{~F} \mathrm{Water,} \\
25 \mathrm{Kw} \text { Added to } \\
\text { Sodium }\end{array}$ & cl \\
\hline
\end{tabular}

Notes:

a/ Energy added to flowing sodium by primary pump.

b/ Total elapsed time before sodium temperature is reached.

c/ Loop can be held in this condition indefinitely without having the sodium freeze.

Tablel8 (Fast Flux Loop) shows that four days might be required before the NaK pump can be turned off. If, as a result of Title I work, it is determined that the decay time is too long to permit loop removal without pump power, the loop handling scheme (Appendix M) will re quire modification to permit maintaining pump power and to permit constant monitoring of temperatures within the loop.

Table 19 (Thermal Flux Loop) shows that the sodium pump must be kept running continuously during loop removal from the reactor. Additional power will also be required for the loop internal heaters during those handling operations in which the test specimen decay heat plus pump input is not sufficient to prevent the sodium from freezing. The handling procedures to be developed shall include means for maintaining power and temperature surveillance during all operations. 


\subsection{Loop Insertion}

The handling procedure for installing the Fast and Thermal Flux Loops into the reactor will be similar to the removal procedure except that the sequence of operations is generally reversed and remote handling is required only if components are radioactive. When installing the Thermal Flux Loop power will be required for the loop heaters to prevent the liquid metal coolant (sodium) from freezing and, therefore, flexible cables will be required. The conceptual handling procedures are detailed in Appendix $M$ and illustrated in Figures $27 \mathrm{~A}$ and $\mathrm{B}$.

\subsection{Canal Transfer}

The transfer of the loops between the reactor and the Hot Cell Facility will be done through the ATR canal (Reference 5). Provisions for use of the canal have been incorporated into the ATR design and are discussed in Part $I$ of this document.

The loop will be discharged from the reactor through the drop tube into a thimble located in the ATR transfer tube. The thimble will be removed from the transfer tube through use of the ATR jib crane and moved to the west end of the storage canal with the overhead 2 -ton crane. A hot cell transfer cart (Figure 28) designed to accept the thimble will transport the loop under the ATR outer wall and into the Hot Cell Facility.

For installation of a loop into the reactor the procedures will be the same except that the sequence will be reversed. The conceptual loop handling procedures for canal transfer are presented in detail in Appendix $M$ and illustrated in Figure 29. 


\section{REPLACEMENT OF EXTENDED CORE AND HAFNIUM FILTER}

The conceptual designs of the extended core and hafnium thermal neutron filter required for the Fast Flux Loop are presented in IDO-2404l. Although their designs have not been established completely, it is expected that they will be handled in a manner similar to that used for handling the ATR core elements. The extended core must be replaced every two reactor cycles; the hafnium filter will last indefinitely.

The reference design Fast Flux Loop will have to be raised vertically upward far enough to permit the extended core and hafnium filter to be raised, as a unit, until they can be moved horizontally from beneath the loop and carried to the drop tube. The distance the loop must be raised will be determined by the loop length and by the length and support configuration of the extended core and filter. The final configuration of these components will be determined in Title $I$.

As presently conceived, the extended core and filter will have to be removed as a single unit. Since the reactor down time of four days is probably not enough time to permit assembling a fresh extended core with the original filter and reinserting this unit into the reactor, two hafnium filters will be required. While one is in service in the reactor, the other will be in the hot cell being assembled with a fresh extended core. 


\section{RESEARCH AND DEVELOPMENT}

On the basis of the handling study work detailed in Appendix $M$ there appears to be little research and development work required for the designing of the loop handling tools and equipment. However, it should be noted that to date sufficient time has not been available for a thorough investigation of certain aspects of loop handling and the related loop design requirements to completely define the problem areas.

The areas which may present problems requiring research and development effort are:

a) The feasibility of using flexible cables when remotely installing a loop into or removing a loop from the reactor.

b) The means of fastening and sealing the loop extension tube to the in-core package section. The fastening will be required to meet the following criteria:

1 - The connection between the two must be designed to be broken at the reactor top head as well as remotely (see item d).

2 - The connection between the two must be water tight and must remain so after repeated use.

3 - The connection must be strong enough to support the in-core section and resist any vibration to which the loop may be subjected.

4 - The connection between the two must allow the making and breaking of the loop power instrumentation and helium lines at the reactor top head.

c) The connections between the extension tube and in-core section for electrical, instrumentation and helium lines must be designed to:

1 - Allow making and breaking at the reactor top head.

2 - Allow for remote making and breaking of the electrical and instrumentation lines.

3 - Withstand any vibration to which the loop may be subjected.

4 - Be waterproof. 
d) The loop handling extension which must be designed to:

1 - Be compatible with the loop extension in-core section fastener.

2 - Be watertight and remain so after repeated use.

3 - Allow for installation and removal at the reactor top head and in the hot cell.w

In addition to the areas listed it is evident that the complex nature of the handling procedures will require that the feasibility be demonstrated in a full size mock-up. 
1 - Advanced Test Reactor - ATR Preliminary Safety Analysis Report Babcock \& Wilcox Co., and Ebasco Services Incorporated, IDO 24040, April 1962.

2 - Design Criteria for a Fast Flux Liquid Metal Loop in the Advanced Test Reactor. Babcock \& Wilcox Co., and Ebasco Services Incorporated, IDO 24041, July 1962.

3 - Design Criteria for a Fast Flux Liquid Metal Loop in the Advanced Test Reactor. Babcock \& Wilcox Co., and Ebasco Services Incorporated, IDO 24041 Supplement I, March 1963.

4 - Summary Report of Design Criteria for a Thermal Flux Liquid Metal Loop in the Advanced Test Reactor. Babcock \& Wilcox Co., and Ebasco Services Incorporated IDO 24042, March 1963.

5 - Record of telephone conversation from M. E. Autio, IDO; W. C. Hayden, IDO; T. E. Hopkins, IDO; to J.A. Scarola, Ebasco Services Incorporated; Ebasco File No.I-C-3.4, March 22, 1962. 



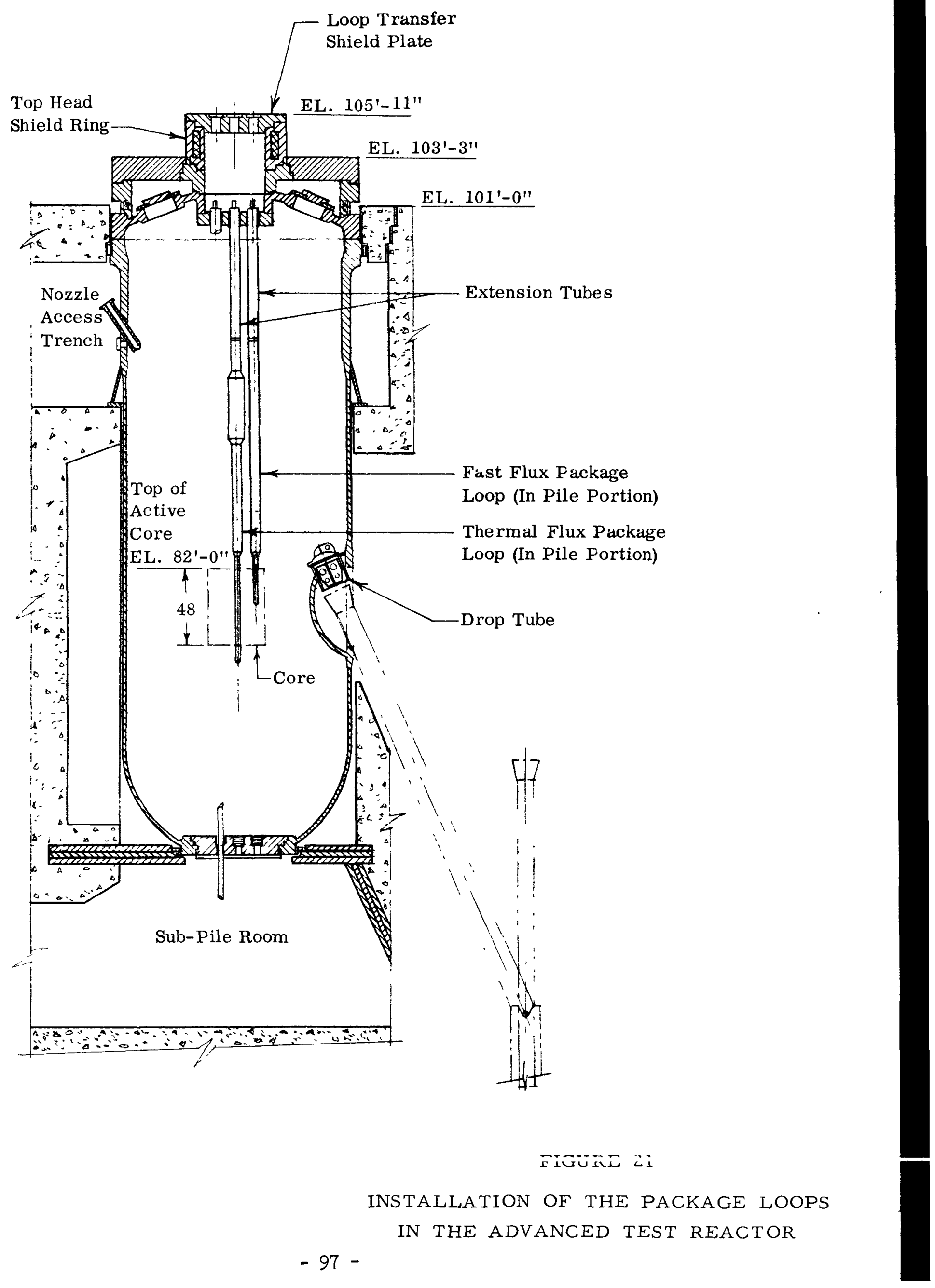




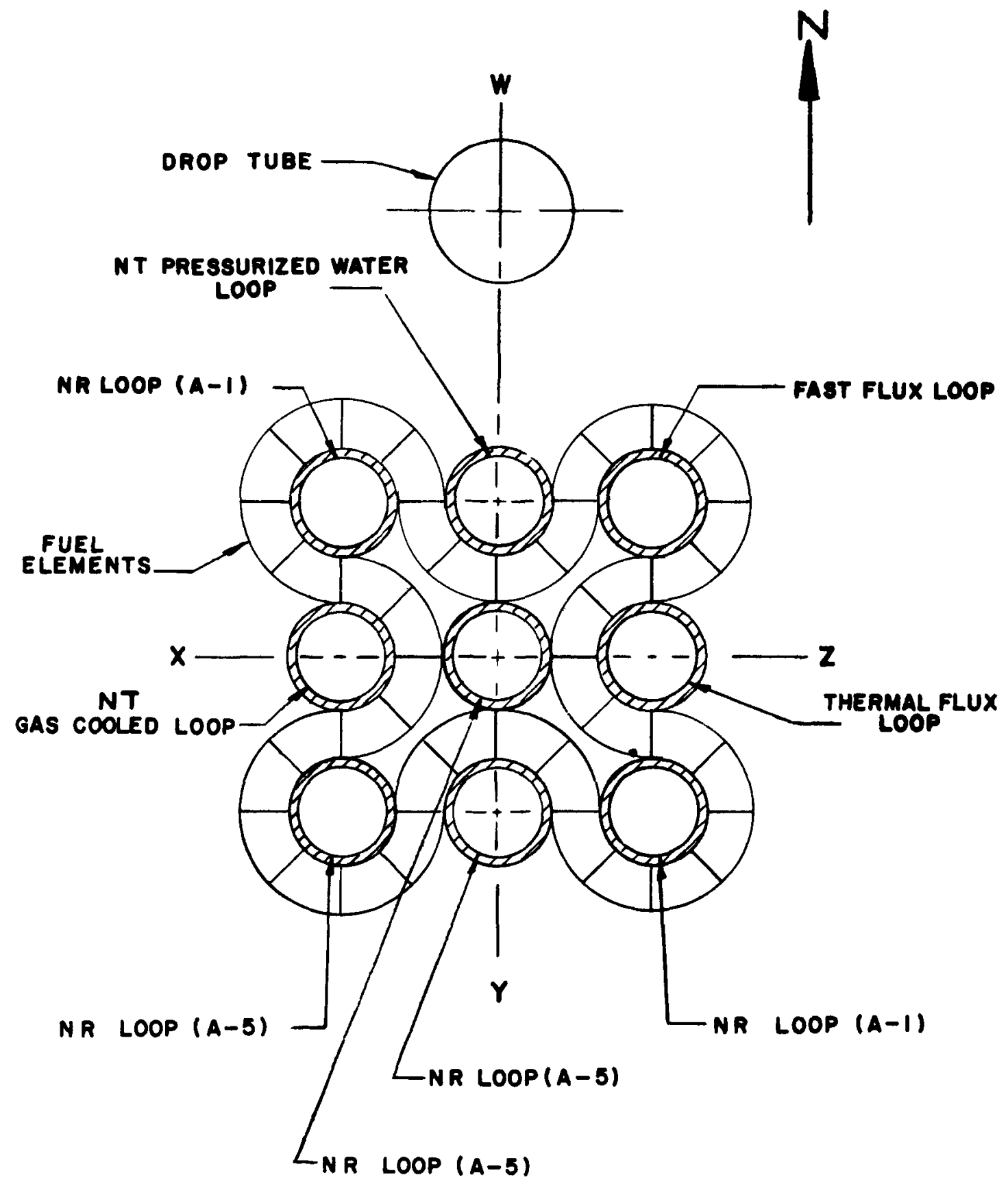

FIGURE 22

ADVANCED TEST REACTOR CORE 


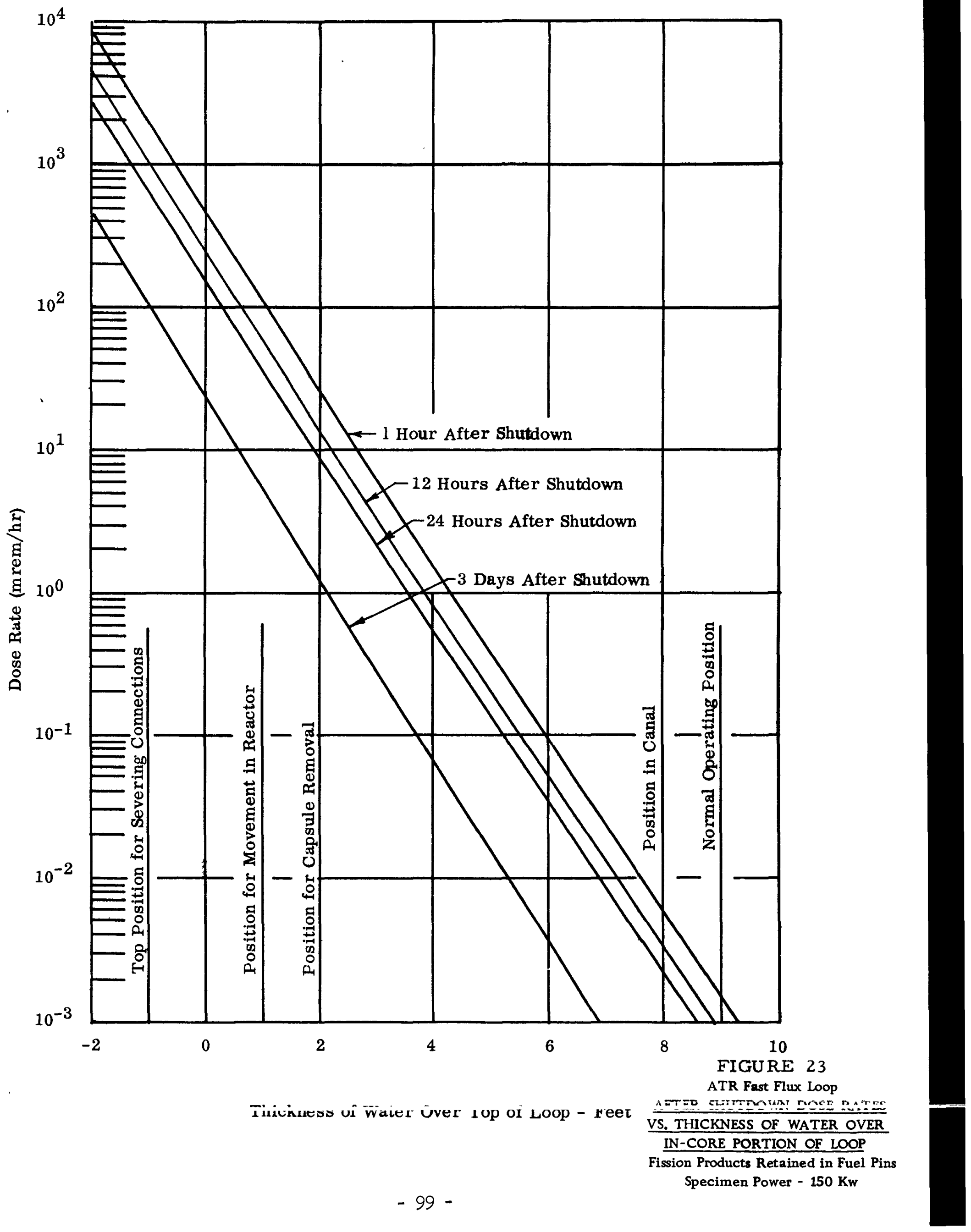




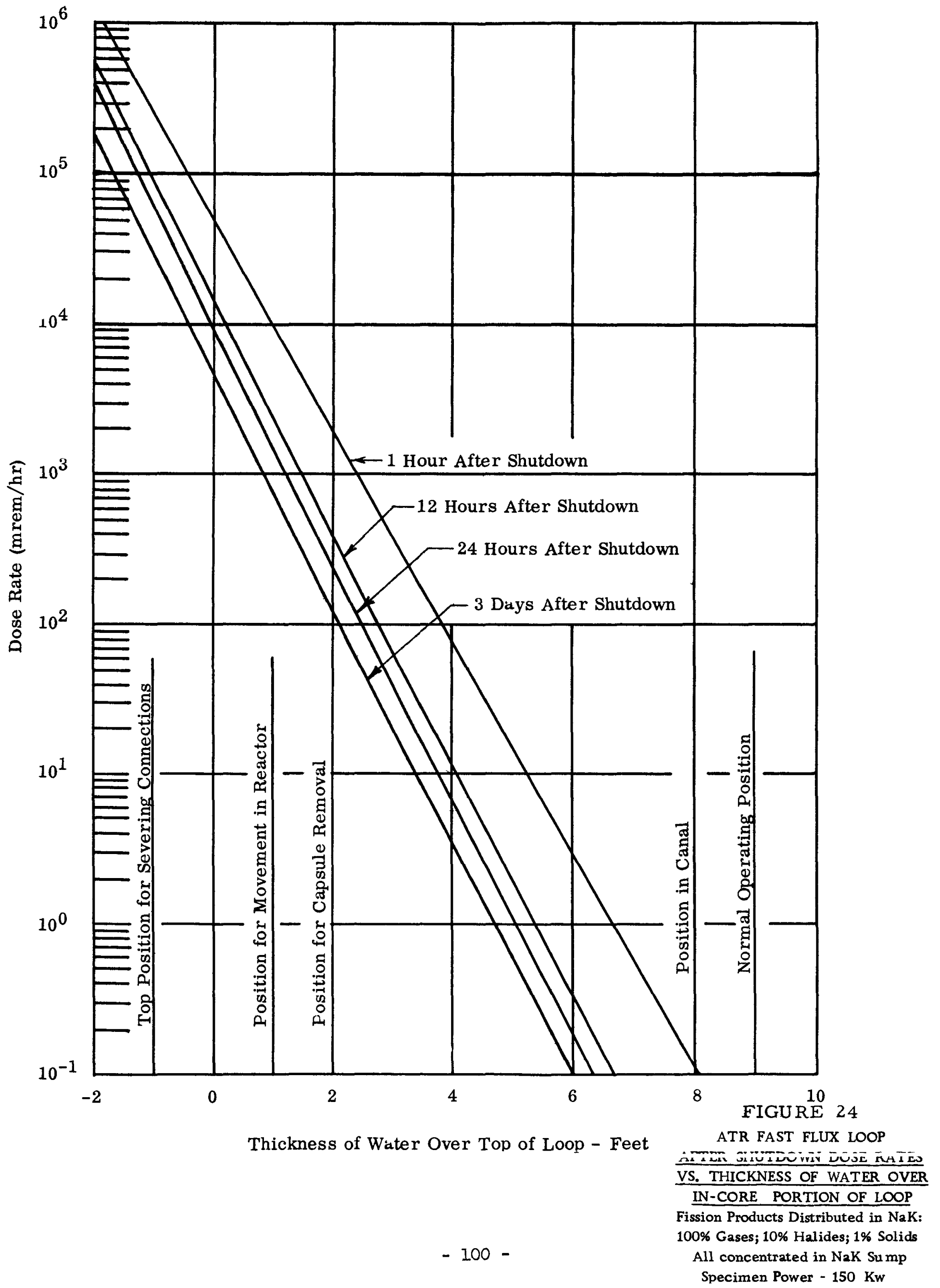




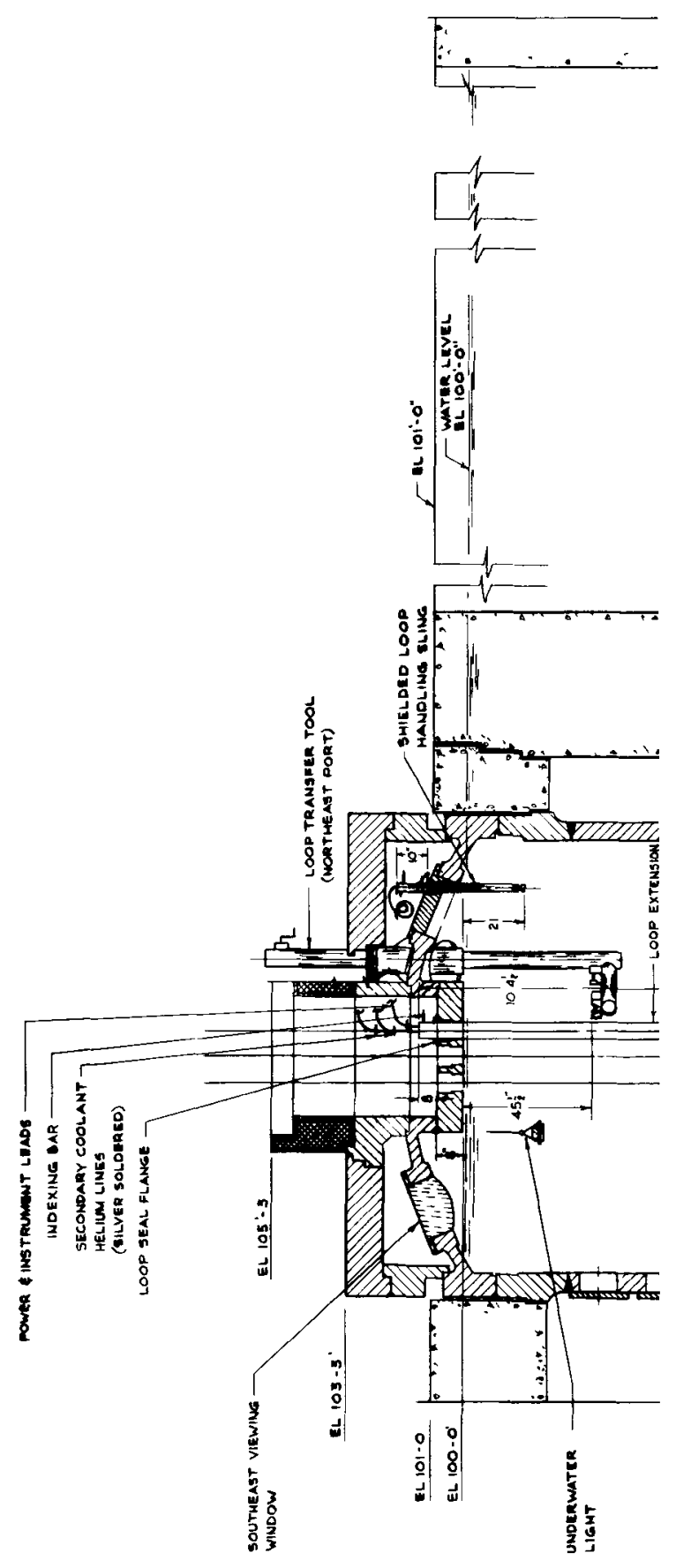

FIGURE 25A

FAST FLUX LIQUID METAL PACKAGE LOOP REMOVAL SCHEME 2 SHEET 1 


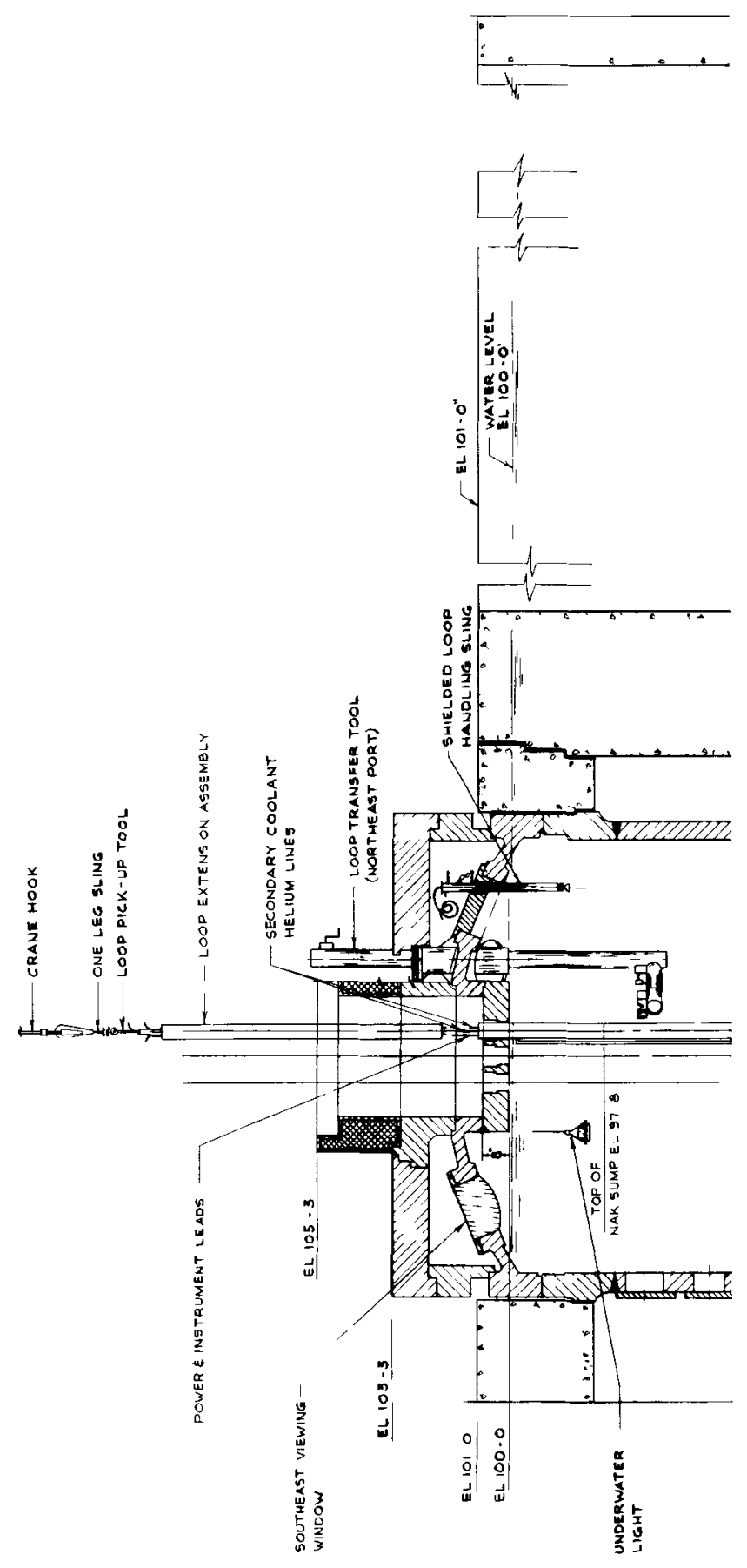

FIGURE 25B

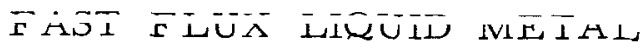
PACKAGE LOOP REMOVAL SCHEME 2 SHEET 2 


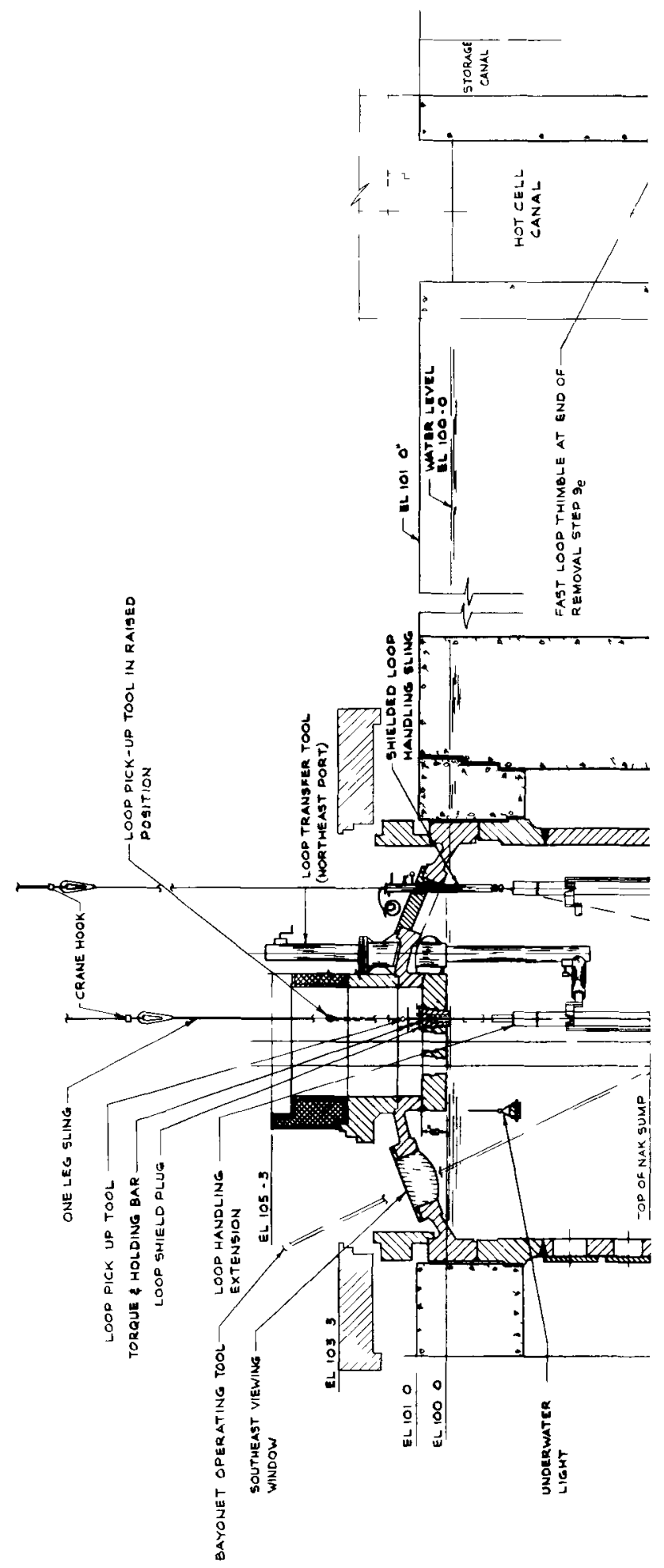

FIGURE 25C

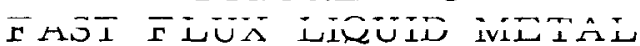
PACKAGE LOOP REMOVAL SCHEME 2 SHEET 3 



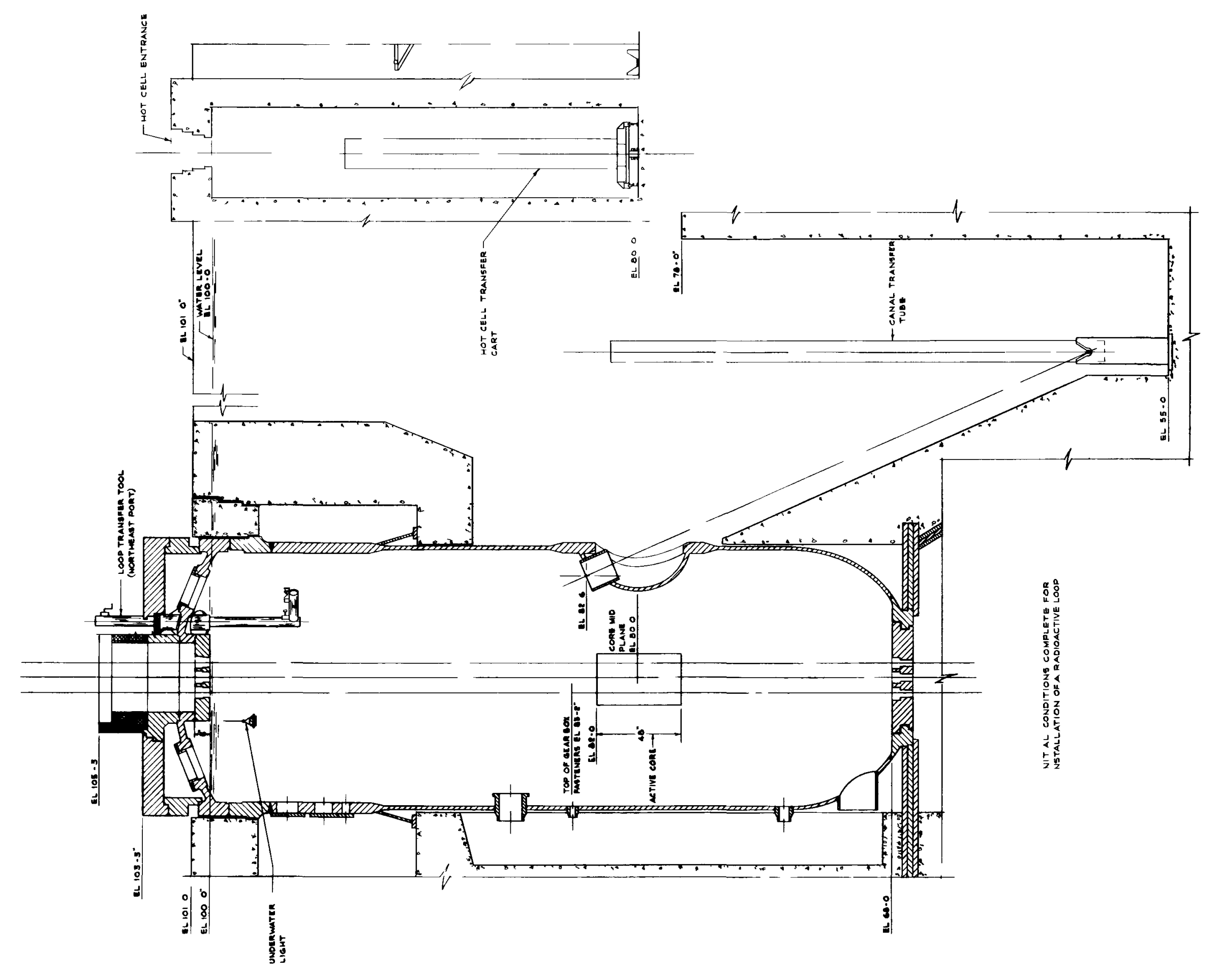




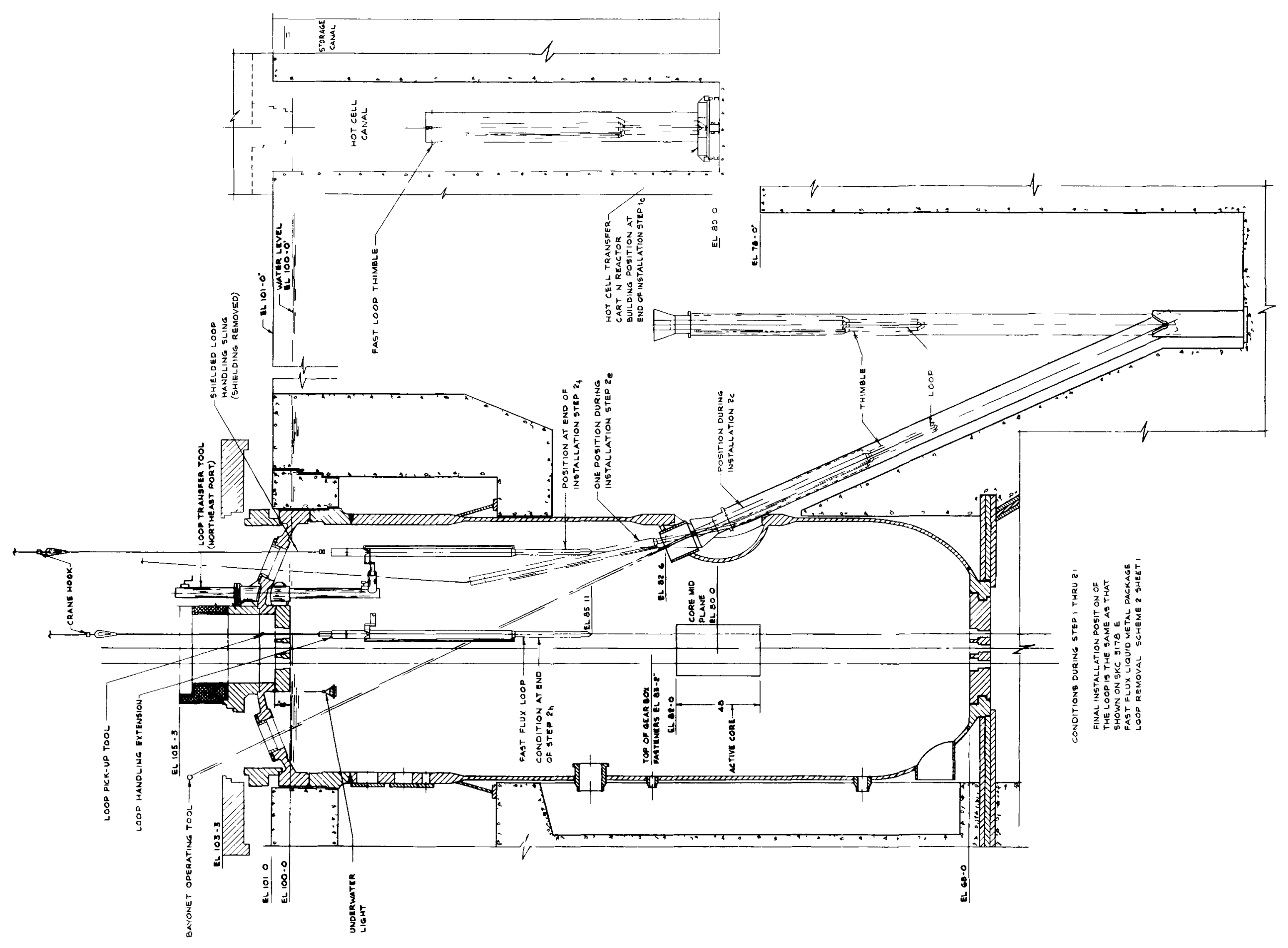




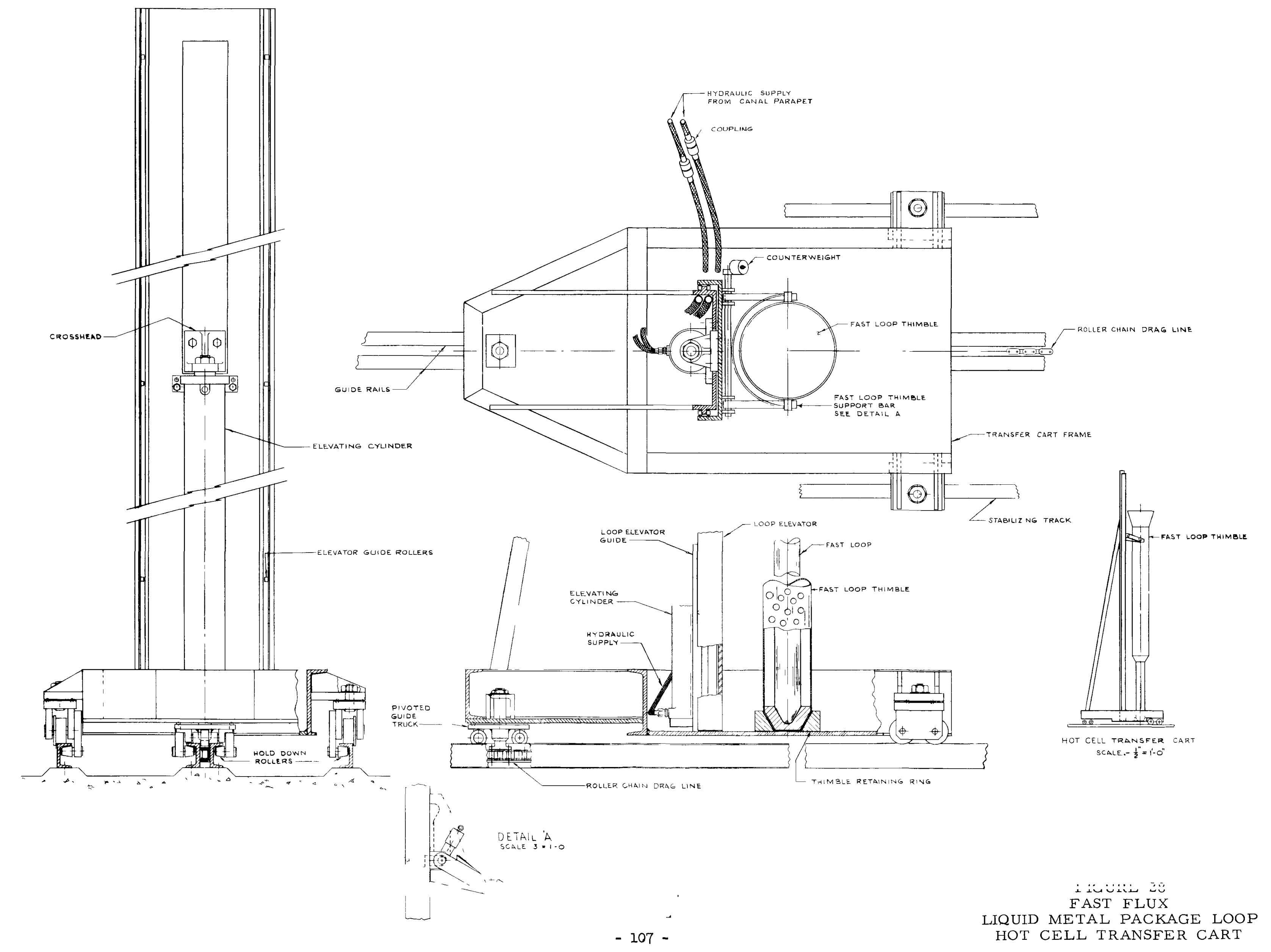




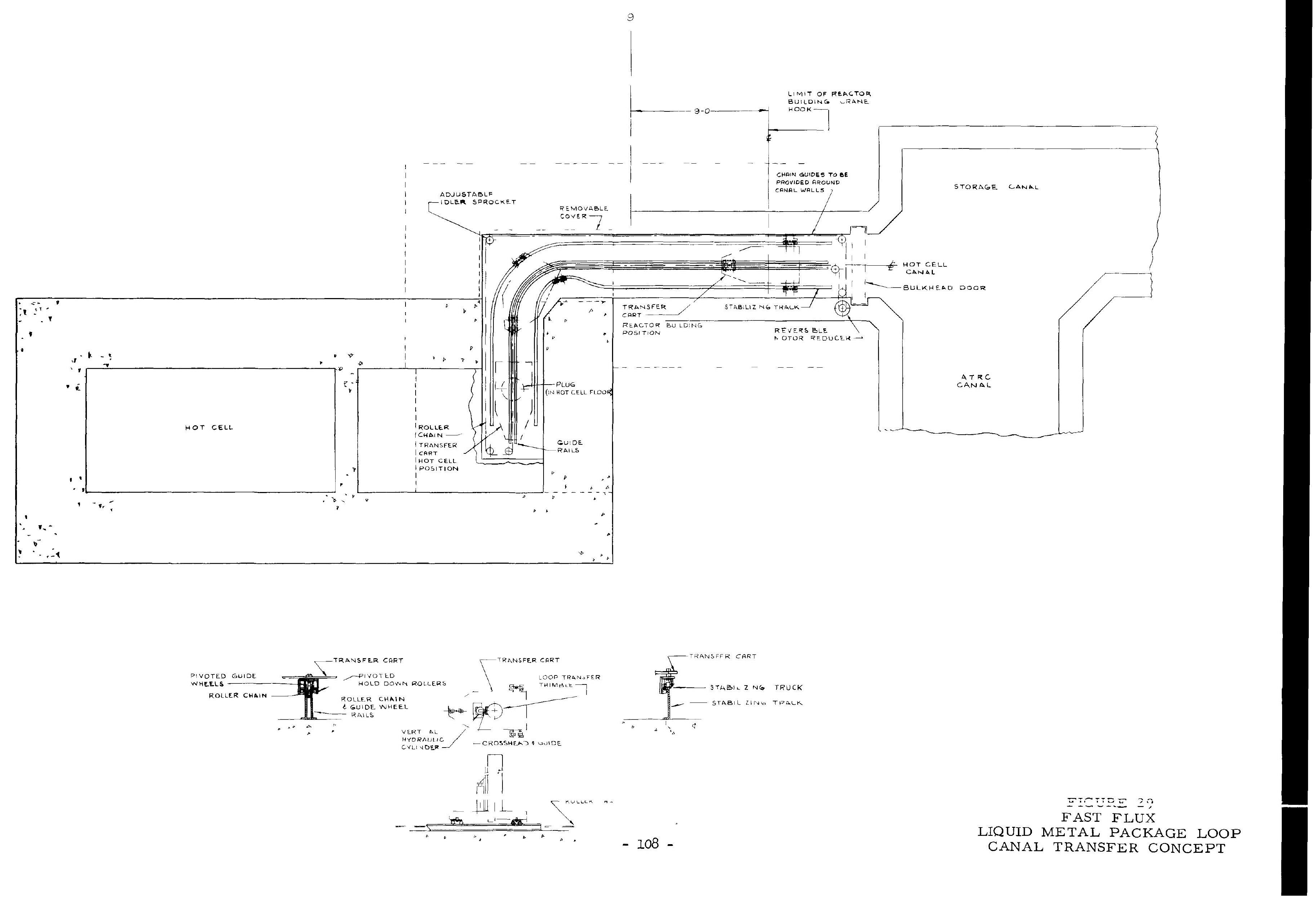


APPENDIX A

Program Design Objectives 
0

-

0 
Design Data Sheet No. M-6001 EO-AEC9954

Contract No. A T (10-1)-1075

June 27, 1962

$\mathrm{D}$ Rosh (UNC)

L Berkowitz (UNC)

E Van Brunt

K A Krauss

\author{
EBASCO SERVICES INCORPORATED \\ ADVANCED TEST REACTOR - DESIGN DATA \\ LIQUID METAL LOOP FACILITIES \\ PROGRAM DESIGN OBJECTIVES
}

\title{
INTRODUCTION
}

Of prime importance in the development of the hot cell facility design are the requirements of the experimenters who will utilize the loops for tests of fuel specimens. These requirements a re presented in US AEC-IDO letters from Mr H M Leppich to R H Gordon on Apri1 20, 1962, entitled "Specimen Examination Requirements \& Hot Cell Facility Design Objectives," and "Liquid Metal Loop Bottom Closure Design Objectives." Copies of these letters are attached in the appendix to this document.

Every effort is made in this design data sheet to meet these design objectives. However, certain modifications to the over-all program objectives are required, particularly those of re-irradiation of a thermal flux test specimen within one or two reactor cycles after termination of the previous irradiation, and re-use of a PW-19 loop in the fast flux loop program. Therefore, this data sheet discusses the problems involved with respect to the se items and the recommended changes to the design objectives which then constitute final design criteria.

This design data sheet is concerned only with the design objectives now furnished by the experimenter and methods for attaining the se objectives modified as required, yet with sufficient flexibility to satisfy all concerned. Separate design data sheets will be issued describing the proposed hot cell facility and the auxiliary systems required for its support.

\section{PURPOSE \& SCOPE}

The purpose and scope of this design data sheet is to discuss the following:

1. The limitations and interrelationships between the design of the loops, the characteristics of irradiated specimens, and the hot cell facility design objectives. 
Design Data Sheet No. M-6001

Liquid Metal Loop Facilities

Program Design Objectives

June 27, 1962

PURPOSE AND SCOPE (Cont'd)

2. The modified over-all program objectives which are compatible with the design limitations of the liquid metal loops and the hot cell facility, and the reasons that make the modifications necessary.

3. The modified specimen examination requirements and hot cell facility design objectives.

4. The problems associated with the specimen examination requirements and the hot cell facility design objectives.

\section{CONCLUSION \& RECOMMENDATIONS}

\section{I - Loop Design}

The following are recommended changes to program objectives which affect loop design from the viewpoint of the hot cell design objectives:

1. The design of the $\mathrm{PW}-19$ loop shall be modified to permit the removal of a thermally hot specimen and also to permit the insertion of either a thermally hot or thermally cold irradiated specimen in a new loop.

2. Re-use (i.e. re-irradiation) of the PW-19 fast flux loop is not a justifiable program objective because extensive redesign would be required to permit removal of oxide contamination from the loop.

3. Since the thermal flux loop is an original design, this design shall permit the removal and replacement of thermally hot or: thermally cold irradiated specimens in both new and used loops. Title I study and R\&D effort over and above the work presently scheduled during the design criteria program will be required to prove that these objectives can be met.

4. Decay times of approximately four weeks for the fast flux program and 27 weeks for the thermal flux program will be required before an irradiated specimen can be re-inserted into a loop. These decay times assume that the specimen has been installed in an empty loop, and that an adequate supply of inert gas is circulated outside the loop through a shroud, thereby maintaining specimen temperatures at or below maximum specified levels. 
Design Data Sheet No. M-6001

Liquid Metal Loop Facilities

Program Design Objectives

June 27, 1962

\section{CONCLUSIONS \& RECOMMENDATIONS (CONT'D)}

\section{II - Hot Cell Design}

The following are recommended changes to program objectives which affect the design of the hot cell facility from the viewpoint of the design of the loop and of specimen examination:

1. The hot cell facility will be designed so that means are provided for transferring the loop both into and out of the cell, and for the removal and re-insertion of test specimens in this cell.

2. The hot cell will be provided with sufficient space to examine test specimens both in a bundle and individually in accordance with the requirements of the experimenters (actual test equipment will be provided by the experi menter). Some minor modifications of specimen examination requirements previously submitted by the experimenters have been made.

3. The design basis for the hot cell facility shall be the following:

a) Storage space will be provided within the facility for two fast flux loops and two thermal flux loops and two fast flux specimens and two thermal flux specimens; these to be placed in suitable shielding pits.

b) Shielding shall be provided for four loops and their specimens. The shielding thickness shall be based upon the activity of thermal flux loops and specimens that have been irradiated for $10,000 \mathrm{hrs}$ since these constitute the most extreme conditions that are anticipated in the facility.

c) Suitable access ports, systems for maintaining desired inert atmospheres, auxiliary equipment and supporting facilities shall be provided as required.

\section{SUMMARY}

\section{I - PROGRAM OBJECTIVES}

The over-all objectives compatible with the loop design and characteristics of an irradiated test specimen with decisions and explanations based upon the discussions in the analysis section of this design data sheet are given in Table $\mathrm{I}$. 
TABLE I

\begin{tabular}{|c|c|c|c|c|c|}
\hline \multirow{2}{*}{\multicolumn{2}{|c|}{ Over-all Program Objective }} & \multicolumn{2}{|c|}{ Fast Flux Loop (See Note a) } & \multicolumn{2}{|r|}{ Thermal Flux Loop } \\
\hline & & Decision & Explanation & Decision & Explanation \\
\hline & $\begin{array}{l}\text { Remove a the rmally hot specimen } \\
\text { from a loop immediately after } \\
\text { irradiation (See Note b). }\end{array}$ & Yes & $\begin{array}{l}\text { PW-19 loop design can be } \\
\text { modified and hot cell equipment } \\
\text { designed for specimen removal. }\end{array}$ & Yes & $\begin{array}{l}\text { Loop and hot cell equipment can } \\
\text { be designed for specimen removal }\end{array}$ \\
\hline \multirow{2}{*}{\multicolumn{2}{|c|}{$\begin{array}{l}\text { 2. Reinsert a thermally hot } \\
\text { specimen (See Note b). } \\
\text { a) In a used loop }\end{array}$}} & No & $\begin{array}{l}\text { Oxide contamination cannot be } \\
\text { removed from PW - } 19 \text { loop without } \\
\text { extensive redesign. }\end{array}$ & $\begin{array}{l}\text { To be } \\
\text { determined } \\
\text { (See Note d) }\end{array}$ & $\begin{array}{l}\text { Feasibility of removal of oxide } \\
\text { contamination within the loop } \\
\text { and/or removal of liquid metal } \\
\text { from a test specimen and remote } \\
\text { sealing of liquid metal and } \\
\text { helium fill lines must be } \\
\text { established. }\end{array}$ \\
\hline & & $\begin{array}{l}\text { To be } \\
\text { determined } \\
\text { (See Note d) }\end{array}$ & $\begin{array}{l}\text { Feasibility of removal of liquid } \\
\text { metal from a test specimen and } \\
\text { remote sealing of liquid metal } \\
\text { and helium fill lines must be } \\
\text { established. }\end{array}$ & $\begin{array}{l}\text { To be } \\
\text { determined } \\
\text { (See Note d) }\end{array}$ & $\begin{array}{l}\text { Feasibility of removal of liquid } \\
\text { metal from a test specimen and } \\
\text { remote sealing of liquid metal } \\
\text { and helium fill lines must be } \\
\text { established. }\end{array}$ \\
\hline \multirow{2}{*}{\multicolumn{2}{|c|}{$\begin{array}{l}\text { 3. Reinsert a thermally cold } \\
\text { specimen (See Note c). } \\
\text { a) In a used loop }\end{array}$}} & No & $\begin{array}{l}\text { Oxide contamination cannot be } \\
\text { removed from PW-19 loop without } \\
\text { extensive redesign. }\end{array}$ & $\begin{array}{l}\text { To be } \\
\text { determined } \\
\text { (See Note d) }\end{array}$ & $\begin{array}{l}\text { Feasibility of removal of oxide } \\
\text { contamination within the loop } \\
\text { and/or removal of liquid metal } \\
\text { from a test specimen and remote } \\
\text { sealing of liquid metal and } \\
\text { helium fill lines must be } \\
\text { established. }\end{array}$ \\
\hline & & $\begin{array}{l}\text { To be } \\
\text { determined } \\
\text { (See Note d) }\end{array}$ & $\begin{array}{l}\text { Feasibility of removal of liquid } \\
\text { metal from a test specimen and } \\
\text { remote sealing of liquid metal } \\
\text { and helium fill lines must be } \\
\text { established. }\end{array}$ & $\begin{array}{l}\text { To be } \\
\text { determined } \\
\text { (See Note d) }\end{array}$ & $\begin{array}{l}\text { Feasibility of removal of liquid } \\
\text { metal from a test specimen and } \\
\text { remote sealing of liquid metal } \\
\text { and helium fill lines must be } \\
\text { established. }\end{array}$ \\
\hline & Reuse of a loop. & No & $\begin{array}{l}\text { Oxide contamination cannot be } \\
\text { removed from PW-19 loop without } \\
\text { extensive redesign. }\end{array}$ & $\begin{array}{l}\text { To be } \\
\text { determined } \\
\text { (See Note d) }\end{array}$ & $\begin{array}{l}\text { Feasibility of removal of oxide } \\
\text { contamination within the loop } \\
\text { and remote sealing of liquid } \\
\text { metal and helium fill lines } \\
\text { must be established. }\end{array}$ \\
\hline
\end{tabular}

Notes:

a. These explanations are founded upon the desire and design objective of using the PW-19 loop design.

Where minor redenign of the loop permits meeting the program objectives such design is contemplated.

b. A thermally hot apecimen is defined as an irradiated specimen requiring forced convection gas cooling.

c. A thermally cold specimen is defined as an irradiated specimen that can stand in a stagnant inert atmosphere without exceeding specified temperature levels.

d. Final decision for those items indicated as "to be determined" is dependent upon Title I study and Research and Development effort. 


\section{I - MAJOR PROBLEMS}

Fulfillment of program objectives will require extensive $R \& D$ work and special Title I Study in the following areas:

1. Design of the thermal flux loop

a) For use with sodium which is solid at normal temperatures.

b) For filling with liquid metal to a desired level (rather than with a specified weight of liquid metal).

c) For removal of oxide contamination (thereby permitting re use of the loop).

2. Modification of the design of the PW-19 loop helium and NaK fill line closures to permit remote sealing in a manner consistent with space limitations and safety considerations (thereby permitting re-irradiation of a specimen). (This problem must also be considered in the design of the thermal flux loop).

3. Design of fast and thermal flux loop closures and hot cell equipment required for removal of specimens from the loops in such a way that the specimens are always completely immersed in liquid metal (thereby permitting prompt removal of a specimen from a loop).

4. Development of procedures for cleaning liquid metal from thermally hot test specimens.

5. Investigation of specimen examination equipment characteristics to ensure sufficient hot cell capacity and capability for use of the equipment.

\section{ANALYSIS}

\section{I - Limitations and Interrelationships Affecting Loop Design Objectives}

The loop design objectives to date have included the re-use of a loop and the re-irradiation of a test specimen within one or two reactor cycles. The re-use of a loop arises from the experimenters' desire to inspect specimens several times during the course of a 10,000 hour irradiation program, and from the program objective of a loop with a 10,000 hour operating life. The re-irradiation of a test specimen within one or two reactor cycles arises from the experimenters' desire to minimize the over-all time required to obtain 10,000 hours of irradiation.

The accomplishment of these objectives is affected by the characteristics of an irradiated test specimen, the purity of the liquid metal in the loop, the design of the loops and the hot cell requirements: 
1) Characteristics of an Irradiated Fuel Specimen

The characteristics of an irradiated fuel specimen which affect hot cell handling and the design of the loop, particularly if it is desired that it be re-used are:

a) Generally, the test specimen will consist of a close packed bundle of rods irradiated at high fluxes. After irradiation, the bundle must either be removed while submerged in liquid metal, or allowed to decay to a point where the liquid metal can be drained and forced convection gas cooling, on the outside of the loop, used to prevent the specimen from exceeding the maximum allowable temperature.

b) The problems associated with insertion of an irradiated test bundle are identical to those of removing the specimen.

c) During hot cell handling and inspection of the test bundle the decay heat will require that auxiliary cooling be supplied to prevent exceeding the maximum allowable temperature.

2) Liquid Metal Purity

The successful operation of the PW-19 loop is directly affected by the purity of the liquid metal coolant. The many small liquid metal passages in the loop require that the NaK be kept as pure as possible.t Typical a re the NaK annuli through the heat exchanger and around the pump shaft leading to the sump, the former being 0.099 inch wide with a flow area of 1.4 square inches and the latter being 0.044 inch wide with a flow area of 0.18 square inches.

If a loop is to be reused, the liquid metal remaining in the loop will have to be kept from becoming contaminated with oxide or the liquid metal recirculated through an external purification system after the loop has been refilled.

3) Design of the Loop

One of the program requirements is the use of the PW-19 Loop, for the fast flux program, without any major modifications. The characteristics of the loop whichaffect the program objectives are:

t When a loop of the PW-19 design was used by Pratt \& Whitney, it was filled with triple distilled $\mathrm{NaK}\left(\leq 5 \mathrm{ppm} \mathrm{O}_{2}\right)$. 
a) Liquid Metal Removal

As presently designed, this loop does not allow the complete draining of $\mathrm{NaK}$ when it is opened for specimen removal. The residual liquid metal will become contaminated with oxide (see Section 4 on the Hot Cell) and will be unsatisfactory for future use. The design of the loop with its small NaK flow passages and open-type of pump and motor design will prevent removal of the residual liquid metal with present day cleaning techniques. In addition, the limitations of the PW-19 loop design does not permit circulation of the liquid metal through an external purification system.

b) Fill Lines

The NaK and helium fill lines on the PW-19 loop were not designed for reuse or remote handling. Problems of spacing, length and attachment are difficult and may not be solvable.

\section{c) Liquid Metal Filling}

The technique for initially filling the fast flux loop, with a predetermined amount of $\mathrm{NaK}$ will not be satisfactory for refilling. To reuse a loop, the design would have to be modified to provide for refilling to a fixed level rather than with a known quantity as is used for the initial fill. The problems associated with refilling the loop are given in detail on page A-15.

Based on the above problems and the requirement that the PW - 19 loop be used without any major design modifications, it is recommended that a new loop be provided each time a specimen is to be irradiated.

The above problems will be applicable to the thermal flux loop unless it can be designed to overcome them. A de tailed analysis of the thermal flux loop design with respect to the above limitations will be required in Title I studies. 
4) Hot Cell

a) Hot Cell Atmosphere

While an inert atmosphere can be maintained in the hot cell facility that is adequate from safety considerations for re. moving and reinserting a test specimen into a loop, it is doubtful that it could be kept at a purity sufficient to prevent oxide contamination of the liquid metal remaining in the loop when it is opened. The problem of maintaining an inert atmosphere of high purity is presented by the physical size of the hot cell, the amount of equipment that will be required in the cell and the work that has to be performed.

b) Dry Box

The use of a dry box in the hot cell of the size required to perform all the functions necessary for removal and reinsertion of a test specimen and to maintain the high purity atmosphere necessary to prevent liquid metal oxidation is not possible. In addition, a dry box presents the problems of limited visibility and accessibility. In order for a dry box to be used, it would be required to perform the following functions:

1 - Form a gas tight seal against the loop.

2 - Cut open the loop.

3 - Remove the specimen from the loop.

4 - Collect the liquid metal drained from the loop.

5 - Permit the transfer of a specimen out of and into the dry box without destroying the environment.

6 - Remove liquid metal from the weld area.

7 - Reinsert the specimen in the loop.

8 - Seal weld the loop closure.

Because a dry box would offer no real advantage over opening a loop in an inert atmosphere cell, and only serve to complicate the handling procedure, a dry box will not be provided. 
Design Data Sheet No. M-6001

Liquid Metal Loop Facilities

Program Design Objectives

June 27, 1962

\section{II - Hot Cell}

1 - Specimen Examination Requirements

Space will be provided in the hot cell facility to examine irradiated fuel test specimens. The following list is based on reference 1 and modified as explained in Item $C$.

A - Test Bundle

1 - Macro and visual inspection (up to $30 \mathrm{x}$ ).

2 - Macro photography.

3 - Measurement of fuel spacing.

B - Individual Test Elements

1 - Macro and visual inspection (up to $30 x$ ).

2 - Macro photography.

3 - Outside dimensions.

4 - Density and/or weight.

5 - Gamma scan for relative activity and fuel redistribution.

6 - Electrical resistivity.

7 - Leak detection.

8 - Non-destructive measurement of meat.

9 - Fission gas collection and reseal of tubes.

10 - Eddy current test for bond.

11 - Ultrasonic testing.

C - Modifications

1 - The examination of released fission gas listed in Reference 1 has been changed to the collection of the fission gas. The MTR-ETR is set up to do this kind of examination on a routine basis. The setting up of an identical facility would be an unnecessary duplication.

2 - The examination of auxiliary dosimetry elements listed in Reference 1 has been eliminated for the same reason as the change in the fission gas examination. 


\section{2 - Hot Cell Facility Design Objectives}

The hot cell facility design objectives are based on those given in reference 1 and have been modified to be consistent with the limitations imposed by the basic design features of the liquid metal loops.

The hot cell design objectives are listed in this section and explained in detail in Section II I.

\section{A - Principal Operations}

1 - Introduce the irradiated loop into the hot cell facility from the canal.

2 - Dry the loop.

3 - Remove irradiated test bundle from the loop.
a) Open loop.
b) Drain liquid metal from the loop.
c) Remove the test bundle from the loop without ex - ceeding the maximum allowable sample temperature and without mechanical damage to the test bundle.

4 - Transfer the test bundle to a storage container.

5 - Transfer the loop to a storage rack or pit.

6 - Examine test bundle and individual elements.
a) Remove liquid metal from the test bundle.
b) Remove the test bundle from the Flow Control Shroud.
c) Inspect bundle and individual elements.
d) Reassemble the test bundle.

7 - Insert irradiated test bundle in a loop.
a) Reinsert the test specimen in the loop without ex- ceeding the maximum allowable sample temperature and without mechanical damage to the test bundle or to the loop.

b) Close and seal the loop. 
c) Refill the loop with clean liquid metal.

d) Purify the liquid metal (thermal loop only).

e) Pressurize the liquid metal cover gas and establish the various helium atmospheres.

f) Close and seal all fill lines.

8 - Test reassembled loop.

a) Inspect for weld integrity. (Accomplished before $7(\mathrm{c})$ above)

b) Operational check of motor, pump, heat ex changer and loop instrumentation.

9 - Remove the loop from the hot cell.

a) Decontaminate outside surface of loop (fission products and alpha contamination).

\section{B - General Hot Cell Facility Requirements}

1 - Space in the hot cell facility to:

a) Store four loops.

b) Store two fast loop specimens and two thermal loop specimens at the same time.

c) Handle loop in a manner to preclude damage to internal components by liquid metal coolant.

d) Store liquid metal waste.

e) Examine test specimens.

f) Perform other miscellaneous operations.

2 - Adequate radiation shielding and containment.

a) Gamma ray shielding for handling two irradiated fuel specimens and two irradiated loops at a time. (Dose rates based on $10,000 \mathrm{hr}$ irradiation).

b) Containment of fission products and alpha contamination. 
Design Data Sheet No. M-6001

Liquid Metal Loop Facilities

Program Design Objectives

June 27, 1962

3 - Miscellaneous Requirements

a) Adequate number and size of access ports and penetration for insertion and removal of loops, transfer of working supplies, for removal, installation and maintenance of in-cell equipment; consistent with the precautions for alpha and gamma activity.

b) Cell atmosphere compatible with the contents and work to be done in the cell.

c) Adequate means for handling failed fuel test specimens.

d) Sufficient viewing windows, manipulators, cranes, lighting and auxiliary equipment to perform the required operations.

e) Provisions for loading expended loops for disposal.

f) Provisions for loading test specimens into casks.

g) Suitable loop utilities for testing assembled loops.

h) Provisions for passing materials such as replacement test specimens into and out of the cell.

i) Adequate supporting facilities.

(1) Facilities and equipment for removal of liquid metal, fission product and alpha activity in the cell.

(2) Warm transfer area and loading area for casks. Spare loops, liquid metal containers, decontamination and maintenance work.

(3) Cold transfer a rea for handling liquid metals, filling new loops and maintenance work.

(4) Change rooms.

(5) Adequate fire control inside and outside of the cell.

(6) Hot and cold liquid waste systems.

j) In-cell and out-of-cell radiation monitoring. 
Design Lata sneet No. M-ouv 1

Liquid Metal Loop Facilities

Program Design Objectives

June 27, 1962

4 - Specimen Examination Equipment.

a) Examination equipment will be supplied by the operator or experimenter.

b) The hot cell will be furnished with sufficient penetrations in the gamma shielding for operation of the examination equipment.

5 - Provisions for Disposal of Expended Loops.

a) The hot cell facility will contain a transfer cask to transport a complete loop from the hot cell to the NRTS burial ground.

\section{I - Hot Cell Problems}

The modified specimen examination requirements and hot cell facility design objectives have been presented above. These requirements and objectives are believed to be reasonable and attainable. However, certain problems are associated with meeting these objectives. These problems are presented in this section to inform the reader of their nature and complexity. It will be clear that the solutions to these problems are not pre sented nor are they indicated in every case; however, it is believed that the probability is good that successful solutions can be found during the course of Title I and R\&D studies. The discussion is presented in the same order as that in Analysis Section II above. Problems inferred from design objectives and specimen examination requirements that are either self evident or that do not represent abnormal hot cell problems have not been discussed here.

\section{1 - Specimen Examination}

The major problems associated with the examination of a fuel test specimen within a short period of time after irradiation stems from the decay heat of the specimen.

A - The inspection of an irradiated and thermally hot test bundle will require that the gas in the cell be circulated around the specimen at a velocity of approximately 10 to $15 \mathrm{fps}$ (Ref 2) to prevent exceeding the maximum allowable temperature.

$B$ - The use of a sensitive balance for weight measurements of a thermally hot specimen will not be possible because of thermal currents generated by the test element.

\section{2 - Hot Cell Facility Design Objectives}

A - Principal Operations

1 - Introduce the irradiated loop into the hot cell from the canal.

This item was not included in reference 1 , and is being listed because of the problem of bringing a $15 \mathrm{ft}$ long loop into an alpha facility. The normal method of pouching items in and out of an alpha cell is not feasible in this case be -

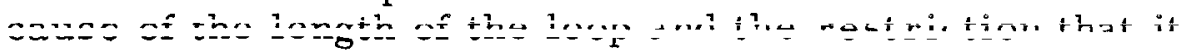
be kept in a vertical position. 
Design Data Sheet No. M-6001

Liquid Metal Loop Facilities

Program Design Objectives

June 27, 1962

The use of an entrance lock, or maintaining the area free of alpha contamination will have to be investigated.

2 - Dry the loop.

This item was not included in reference $l$ and is being listed to point out the problem of introducing water vapor into the cell. The problem of removing this water vapor from the cell atmosphere particularly if it is an inert gas must be considered.

3 - Remove irradiated test bundle from the loop.

The major problem of removing an irradiated test bundle is that of preventing the specimen from exceeding the maximum allowable temperature. To remove a specimen from the loop it must be kept in a liquid metal bath or allowed to decay for a period of approximately 4 weeks after which supplementary gas cooling on the outside of the fast flux loop can be used (ref 3). Preliminary calculations indicate that a decay of 27 weeks will be required for the thermal flux loop.

4 - Examine test bundle and individual elements.

The cleaning of liquid metal from an irradiated specimen after a short decay time presents a problem because of the high decay heat generation, and will require further investigation during Title I. Some of the problems associated with the use of conventional cleaning methods are:

a) Decomposition of alcohols.

b) Hot spots caused by oxide formation when using a wet gas.

c) $\mathrm{Pu}, \mathrm{U}$-water reactions in a fuel element with a failed cladding.

d) Water reaction with the liquid metal bond in a fuel element with a failed cladding.

e) Formation of insoluble hydroxides when using water or moist gas. 
5 - Insert irradiated test bundle in a loop.

a) Reinsertion of a thermally hot test bundle.

A decay of approximately 4 weeks for the fast flux loop and 27 weeks for the thermal flux loop will be required before a test specimen can be re. irradiated.

These decay times are based on the cooling of the outside of the loop with flowing helium to prevent exceeding the maximum allowable specimen temperature of $1000 \mathrm{~F}$ (ref 4). For specimens with lower temperature limitations, such as metallic fuels, correspondingly longer decay times will be required.

b) Refill the loop with clean liquid metal.

The design objective of weighing the liquid metal removed from the loop (reference 1) has been eliminated. If the design of the thermal loop is similar to that of the fast loop, this method of determining the amount of liquid metal required to refill the loop is not satisfactory in that:

(1) The fill level of the loop has to be held to - $0.030 \mathrm{inch}(\operatorname{ref} 5)$.

(2) The liquid metal has to be weighed to an accuracy of approximately $1 \%$.

(3) The loss of any liquid metal by leakage or spilling during handling would have to be accounted for.

c) Purify the liquid metal.

The liquid metal in the loop will have to be purified to remove oxides which could plug the small liquid metal flow passages.

The design of the fast flux loop does not permit the circulation of the liquid metal through an external purification system.

The purification of the liquid metal in the thermal loop by use of an external system and self-contained cold trap will require study during Title I. 
6 - Test reassembled loops.

a) Inspect for weld integrity.

The inspection of seal welds in liquid metal systems consists of $x$-ray, die penetrant check, and helium mass spectrometer leak checking.

A technique will have to be developed for $x$-ray inspection of the closure weld when the loop contains an irradiated fuel specimen.

7 - Remove the loop from the hot cell.

The amount of fission product and alpha activity contaminating the surface of the loop will have to be kept to a minimum. The physical size and requirement that the loop be maintained in a vertical position will make decontamination by scrubbing and acid cleaning a complex problem.

\section{B - General Hot Cell Facility Requirements}

1 - Space in the hot cell.

a) Loops and test specimens will be stored in the hot cell in such a way that they a re isolated from the working areas to protect them against damage and contamination. By making the storage areas shielded pits, the size of the shielding required for the hot cell walls may be reduced.

2 - Adequate radiation shielding and containment.

a) Loop and specimen storage.

The gamma shielding for two loops and test specimen is based on the philosophy of handling one loop and specimen at a time with the remaining loops in the storage areas. The additional shielding for the second set is provided as a contingency factor.

b) Liquid Metal Storage.

Radioactive liquid waste will be stored in fireproof containers within the hot cell until disposed of. 
Design Data Sheet No. M-6001

Liquid Metal Loop Facilities

Program Design Objectives

June 27, 1962

\section{REFERENCES:}

1. USAEC-IDO letters RTR: JCMc, H. M. Leppich to R H Gordon, April 20, 1962.

2. Personal communication from W. G. Blessing based on decay heat generation made by APDA.

3. Babcock and Wilcox Co Design Data Sheet R-6007,

"Decay Periods for Loop Handling", September 12, 1962.

4. Atomic Power Development Associates, Report APDA 144, "Conceptual Design of an In-Pile Package Loop for Fast Reactor Fuel Testing", July 28, 1961.

5. Pratt \& Whitney Aircraft, Memo CNLM-1992,

"Filling Instructions for Pratt and Whitney Forced Convection Liquid Metal Inpile Loop Experiment (PW-19)", April 29, 1959. 
Design Data Sheet No. M-600l

Liquid Metal Loop Facilities

Program Design Objectives

June 27, 1962

APPENDIX 
- COPY -

UNITED STATES ATOMIC ENERGY COMMISSION

IDAHO OPERATIONS OFFICE

P. O. Box 2108

Idaho Falls, Idaho

In reply refer to:

RTR:JCMC

April 20, 1962

Ebasco Services, Incorporated

Two Rector Street

New York 6, New York

Attention: Mr. R. H. Gordon, Project Manager

Subject: LIQUID METAL LOOP HOT CELL FACILITIES OBJECTIVES

Gentlemen:

Transmitted herewith are the design objectives (Enclosure l) for the hot cell to be used to service the liquid metal loops.

Also transmitted herewith is a list of examination requirements (Enclosure 2) that should be met in the hot cell. These requirements should be considered in determining the space and utilities to be provided in the hot cell. The instruments and equipment for these examinations should not be provided.

$$
\text { Very truly yours, }
$$

H. M. Leppich, Director

Engineering and Construction Division

Idaho Operations Office

Enclosures:

(1) Design objectives

(2) Examination requirements

CC: G. W. Wensch, DRD (2)

A. Giambusso, DRD

F. Smith, COO

L. J. Weber, PPCo. (5)

A. H. Lazar, B\&W (5)

T. E. Hopkins, IDO

W. G. Blessing, APDA (3)

J. V. Levy, CPAO

E. Sowa, ANL

K. Cohen, GE-APED

K. Goldmann, UNC

R. W. Dickinson, AI 


\section{A. Principal Operations}

1. Remove irradiated test bundle from the loop.

a. Drain liquid metal from the loop.

b. Contain and measure the liquid metal drained from the loop.

c. Open the bottom closure section of the loop.

d. Remove the test bundle from the loop without exceeding the maximum allowable sample temperature and without mechanical damage to the test bundle.

e. Transfer the test bundle to a storage container.

f. Transfer the loop to a storage rack.

2. Examine test bundle and individual elements.

a. See the attached examination requirements.

b. Reassemble the test bundle.

3. Insert irradiated test bundle into the loop.

a. Reinsert the test specimen into the loop without exceeding the maximum allowable sample temperature and without mechanical damage to the test bundle.

b. Close and seal the bottom closure section of the loop.

c. Refill the loop with the required measured quantity of clean liquid metal and cover gas.

4. Test reassembled loop.

a. Inspect for weld integ rity.

b. Test performance of motor, pump, heat exchanger and loop instrumentation. 


\section{B. General Hot Cell Facility Requirements}

1. Sufficient space and head room inside the hot cell for handling loops.
a. Four loop positions required.
b. Handle loop in a manner to preclude damage to internal components by liquid metal coolant.
c. Space for examining test bundle and individual elements.

2. Adequate radiation shielding and containment.

a. Two fast loop fueled test specimens and two thermal loop fueled test speciments in the hot cell at the same time.

b. Adequate Gamma - ray shielding.

c. Provision for containing and preventing the spread of fission products and alpha contamination.

d. Humidity and temperature controlled atmosphere.

e. The desirability of an inert gas recirculation and cleanup system should be examined.

3. Adequate hot cell facilities.

a. Adequate number and size of access ports for insertion and removal of loops, transfer of working supplies and for removal, installation, and maint enance of in-cell equipment.

b. Adequate facilities for handling failed fueled test specimens.

c. Sufficient number and proper location of viewing windows and periscopes.

d. Provision for loading expended loops for disposal.

e. Provision for loading test specimens into casks.

f. Adequate lighting for visual observations and major operations; this should include provision for portable spot lights. 
B. General Hot Cell Facility Requirements (Continued)

3. Adequate hot cell facilities (Continued)

g. Sufficient number and suitable types of cranes and manipulators to perform the required operations.

h. Provision for disposal of waste liquid metal.

i. Suitable tools and fixtures to perform all necessary operations except examination of the test bundle and individual elements.

j. Suitable loop utilities for testing assembled loops.

k. Provision for passing materials such as replacement test specimens into the cell.

4. Adequate supporting facilities.

a. Facilities and equipment for decontamination of liquid metal, fission product and alpha activity in the cell.

b. Warm transfer area and loading area for casks, spare loops, liquid metal containers, etc.

c. Change room (cold and warm) equipped with showers, monitors, etc.

d. Adequate fire control in event of a liquid metal spill.

e. Cold transfer area for handling liquid metals and filling new loops.

C. Time Schedule

1. Remove loop from ATR.

2. Permit loop to cool.

3. Transfer loop to hot cell.

4. Remove test bundle from loop.

5. Examine test bundle and individual elements.

6. Reinsert fuel bundle into loop. 
C. Time Schedule (Continued)

7. Test reassembled loop.

8. Transfer loop to ATR.

9. Insert loop in ATR.

NOTE: It is hoped that the above items can be accomplished in approximately twenty-one (21) days (2 days shut down, plus 17 days ATR cycle, plus 2 days shutdown). 
EXAMINATION REQUIREMENTS

\section{Examinations}

Before Removal of Fuel from Bundle

1. Macro and Visual Inspection (up to $30 \mathrm{X}$ )

2. Measurement of Fuel Spacing

After Removal of Fuel from Bundle Nondestructive Testing

1. Macro Inspection (up to $30 \mathrm{X}$ )

2. Macro Photography

3. Fuel Outside Dimensions

4. Density and/or Weight

5. Gamma Scan for Relative Activity and Fuel Redistribution

6. Electrical Resistivity

7. Leak Detection

8. Measurement of Meat by Nondestructive Test (if possible)

9. Fission Gas Release and Reseal of Tubes

10. Auxiliary Dosimetry Elements

11. Eddy Current Test for Bond

12. Ultrasonic Testing

1 Clad integral with fuel.

2 Sodium bonded elements.

Fuel Type

Ceramic Cermet Metallic

$\mathrm{X}$

$\mathrm{x}$

$\mathrm{X}$

$\mathrm{x}$

$\mathrm{x}$

$\mathrm{x}$

$\mathrm{X}$

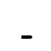

X

$\mathrm{X}$

X

$\mathrm{x}$

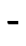

$\mathrm{x}$ $\mathrm{x}$

$x$

$\mathrm{x}$

$\mathrm{x}$

$\mathrm{x}$

$\mathrm{x}$

$x$

$x^{1}$

$x$

$x^{2}$

$x^{2}$

x

$\mathrm{x}$

$x$ 


\section{UNITED STATES ATOMIC ENERGY COMMISSION}

\section{IDAHO OPERATIONS OFFICE}

P. O. Box 2108

Idaho Falls, Idaho

In reply refer to:

RTR:JCMC

April 20, 1962

Ebasco Services, Incorporated

Two Rector Street

New York 6, New York

Attention: Mr. R. H. Gordon, Project Manager

Subject: LIQUID METAL LOOP BOTTOM CLOSURE DESIGN OBJECTIVES

Gentlemen:

The following is a list of the objectives to be achieved by the bottom closure of the liquid metal loops:

1. Removal and reinsertion of an irradiated fuel bundle as specified in hot cell facility design objectives.

2. Design should provide for reuse of loop for four irradiations subsequent to first irradiation.

3. Design must provide for transfer of fuel bundle without exceeding maximum allowable fuel surface temperature.

4. Simple design as possible; must be practical for hot cell remote operations.

$$
\text { Very truly yours, }
$$

H. M. Leppich, Director

Engineering and Construction Division

Idaho Operations Office

CC: G. W. Wensch, DRD (2)

A. Giambusso, DRD

F. Smith, COO

L. J. Weber, PPCo. (5)

A. H. Lazar, B\&W (5)

T. E. Hopkins, IDO

W. G. Blessing, APDA (3)

J. V. Levy, CPAO

E. Sowa, ANL

K. Cohen, GE-APED

K. Goldmann, UNC

R. W. Dickins on, AI 
$$
\text { . }
$$ 
APPENDIX B

Hot Cell Facility

- 137 - 
-

•

0 


\section{EBASCO SERVICES INCORPORATED ADVANCED TEST REACTOR \\ LIQUID METAL LOOP FACILITIES \\ FAST AND THERMAL FLUX LOOPS \\ HOT CELL FACILITY}

\section{PURPOSE AND SCOPE}

This design data sheet presents the conceptual design of the hot cell facility for the ATR Liquid Metal Package Loop Program.

The scope of this data sheet is to present the over-all concept of the hot ell facility and does not cover design details beyond those required to meet this objective.

\section{DESIGN BASIS}

The hot cell facility has been designed to meet the Liquid Metal program Objective presented in Design Data Sheet M-6001, "Program Design Objectives," June 27, 1962.

The location of the hot cell facility was predetermined by ATR considerations and, therefore, the conceptual layouts which are presented in this data sheet have been designed to be accommodated within the allotted area.

Wherever possible ATR services and utilities have been used to minimize the cost and size of the hot cell facility.

\section{CONCLUSIONS AND RECOMMENDATIONS}

1 - The hot cell facility will be a separate building containing hot, warm and clean working areas.

2 - The hot working area for handling irradiated loops and specimens will contain two cells. The first cell will have an air atmosphere and the second an argon atmosphere.

3 - The hot cell facility will be designed so that it does not breach the integrity of the ATR gas tight areas.

4 - Two hot cell facility layouts are presented, one with the hot cell parallel to the ATR wall, and one with the hot cell perpendicular to the ATR wall. It is recommended that the hot cell facility be designed on the basis of the second scheme (hot cell perpendicular).

5 - A preliminary investigation indicates that the $r=:=$ infficient space for supporting equipment and systems. However, a detailed Title I study will be required before the size of the building can be fixed. 


\section{DESCRIPTION}

General

The hot cell facility has been designed to be a separate building adjacent to the ATR as directed by the USAEC, Idaho Operations Office (Ref. 1).

The hot cell facility will be independent of the ATR building with the only interconnection between the two being utility and service lines, radioactive liquid waste lines and the transfer canal.

Several conceptual designs of a hot cell facility were investi gated, and all but two were discarded as being impractical or presenting complex technical and handling problems. The two concepts for the hot cell facility (Schemes 1 and 2) are shown in Figures 1 and 2 , respectively and differ mainly in the placement of the hot cells. While the description given is for the recommended design, it is applicable to both.

\section{Location}

The location for the hot cell facility was predetermined by ATR considerations which were the requirements that:

1 - The loops are to be transferred from the reactor to the hot cell through the canal (Ref. 2).

2 - Provisions for extending the canal have been left at the west end of the canal and ATR building in the area between the storage canal and the critical facility bulkhead (Ref. 2).

3 - The hot cell facility is to be outside but adjacent to the ATR building (Ref. 1).

The area in which the hot cell facility must be located, (Figure 3) because of the above requirements, is $100 \mathrm{ft}$ long by $40-1 / 2$ $\mathrm{ft}$ wide and straddled on the north and south by truck access roads. The access roads, as presently designed, are $20 \mathrm{ft}$ wide and pass into the ATR building through $14 \mathrm{ft}$ and $12 \mathrm{ft}$ wide truck doors respectively.

In order to provide sufficient space for the hot cull isility, the roadway gutters adjacent to the facility will have to be removed and the roads pitched to carry runoff to the gutters along the outer edges.

Hot Cell Facility Building

The hot cell facility will be housed in an aluminum sided building approximately $78 \mathrm{ft}$ long by $48 \mathrm{ft}$ wide. The building height will be $32 \mathrm{ft}$ above grade (to elevation 129) and extend below grade for $18 \mathrm{ft}$ (to elevation 79 ). 
The hot cell facility has been designed to be a self-supporting unit and is divided into 4 areas based on radiation levels. These areas are:

I - Hot cells for handling highly radioactive material.

2 - Warm areas for handling low level radiation.

3 - Controlled clean areas which will have a radiation background level higher than normal background, but no higher than $0.25 \mathrm{mr} / \mathrm{hr}$.

4 - Clean a rea having only a normal background radiation level.

The hot cell facility will be isolated from the ATR building by having the wall between them extend into the canal below the water level.

Hot Cells

The cave area for handling radioactive material will be shielded with $4-1 / 2 \mathrm{ft}$ thick high-density concrete $(3.55 \mathrm{~g} / \mathrm{cc})$ so that the radiation level at the outside surface will not exceed $0.25 \mathrm{mr} / \mathrm{hr}$ (Ref. 3). The cave will be designed to contain alpha as well as gamma contamination and therefore all penetrations of the shielding wall will be gas tight. The cave has been partitioned into two cells each $8 \mathrm{ft}$ deep by $25 \mathrm{ft}$ high. The first cell will be $12 \mathrm{ft}$ long and have a once through air atmosphere while the second cell will be $16 \mathrm{ft}$ long and have a recirculating argon atmosphere. The size and atmosphere of the cells have been based on the work that has to be performed on the loops and is discussed in detail in the Analysis Section.

Each cell will contain two lead glass windows with 40 in. by 40 in. hot faces, two pairs of booted master slave manipulators, overhead crane, and a stereo viewer sleeve; all equipment will be at normal height from the cell floor. In addition, the argon cell will contain a remote controlled manipulator and a viewing window in the end'wall located approximately $16-1 / 2 \mathrm{ft}$ above the cell floor. The need for an upper operating level in the hot cells has been eliminated by the use of shielded pits into which the loop can be lowered when work on the upper end is required.

Access to each cell will be provided by the following gas tight penetrations of the shield walls:

1 - Equipment and personnel door $\left(3^{\prime} 6^{\prime \prime} \mathrm{w} \times 6^{\prime} 6^{\prime \prime} \mathrm{h}\right)$ in the rear wall.

2 - Shielded 12 in. diameter transfer drawer in the rear wall, 
3 - Shielded 12 in. diameter transfer port in the floor.

4 - Shielded $2 \mathrm{ft}$ diameter plug in the roof for emergency use only.

Access between cells will be provided by a transfer lock loca. ted in the cave partition wall and by a transfer cask located in the warm area below the hot cells.

The transfer cask, which will seal against the 12 in.transfer ports in the cell floor, will also be used to introduce new loops into the hot cells and to remove ir radiated loops from the hot cells for transporting to the NRTS burial grounds.

To provide for increased utilization of the hot cells, ducts from the building ventilation system will be incorporated into the argon cell so that it can be operated as a standard air atmosphere cell if required.

Warm Area

The warm area will have a controlled access ard contain three working levels for handling materials with iow level contamination, materials with high level contamination when contained within proper shielding, and for access to the hot cells.

Stairs within the warm area and a hatch in the floor of the upper level will provide personnel and crane access to the lower levels.

The upper level will be a high bay area with an overhead crane and contain the hot cell working face (rear wall), decontamina tion area, radioactive storage and a personnel hot change room.

The intermediate level will contair the exhaust equipment for the building ventilation system and a warm machine shop.

The lower level will contain the shielded cask for loop transfer and the hot cell argon recirculation and purification system.

\section{Controlled Clean Area}

The controlled clean areas will be located on the main floor of the building and consist of an area containing the operating face (front wall) of the hot cells, radiation control office, and a separate area for a personnel change room. The radiation control office has been located at the entrance to the building to allow for full administrative control of personnel entering and leaving.

\section{Clean Area}

The clean areas will consist of offices and lavatories located on the second floor of the building, building heating and ventilating equipment on the second floor and a separate high bay area for handling liquid metal and new loops. 


\section{Building Ventilation}

The building heating and ventilation system will be designed to supply air to the various areas on a radiation level basis.

Air will be drawn into the building by the ventilation equipment located at the east end of the second floor. The air will be ducted to the clean area (offices) and the controlled clean area (hot cell operating face) through individual distribution systems. The air from the former area will be ducted directly to exhaust equipment located in the intermediate level warm area. A quantity of air sufficient to maintain the pressure gradient between areas will be drawn from the controlled clean area into the cold change room, then into the hot change room, into the warm working area, through the air cell and then ducted into the exhaust equipment. The remainder of the air from the controlled clean area will be ducted directly to the exhaust equipment. The exhaust air will be ducted to the ATR stack.

The spread of contamination from the hot to warm or warm to cold areas will be minimized by the use of pressure differentials between the areas and by filters located at appropriate points in the ventilation system.

The new loop and liquid metal handling area, which will not be supplied by the building ventilation system, will have roof ventilators to prevent the spread of smoke into the building in the event of a liquid metal fire.

\section{ANALYSIS}

\section{Loop Handling and Hot Cell Design}

As previously noted one of the requirements is that the loop be transferred from the reactor to the hot cell through the canal. The loop when brought into the hot cell will have to be dried. The problem of removing large quantities of water vapor from an inert gas atmosphere has led to the use of a once throughair atmosphere for the first hot cell.

The pyrophoric nature of the materials within the loops (liquid metal and fissionable fuels) requires that they be maintained in an inert atmosphere. To accomplish this, the second hot cell will contain a recirculating argon atmosphere,

The requirement that the loops be handled in a vertical position and the necessity of maintaining the integrity of the argon atmosphere has led to the use of an external transfer cask for moving the loops between cells. A transfer cask located underneath the cell rather than on top was chosen for the following reasons:

1 - The sask ran he a simpler desizn het renuiring any mechanisms for raising or lowering the loops. 
2 - The hot cell seal and shielding can be a simple gas tight plug.

3 - The plug can be easily reached and removed into the hot cell with the manipulators and crane.

4 - The cask can be used to transport loops to the NRTS burial grounds.

\section{Hot Cell Size}

The hot cells have been sized to accomplish the post-irradiation objectives of the program (Ref. 4). However, since the equipment for performing the various operations will have to be of a specialized nature (and as yet not designed) plus the fact that the inspection equipment will not be supplied by the ArchitectEngineer (Ref. 4), the sizes shown have been based on estimates of the space required.

Hot cell Number 1 (air atmosphere) will be $12 \mathrm{ft}$ long by $8 \mathrm{ft}$ deep and will be used for the following operations:

1 - Transfer of the loops from the canal to the hot cell and from the hot cell to the canal.

2 - Drying loops brought into the hot cell from the canal.

3 - Inspection of irradiated specimens as listed in Ref. 4.

4 - Removal of radioactive contamination (alpha and gamma) from the outside of a loop prior to reirradiation.

The $12 \mathrm{ft}$ length was deemed to be the minimum size for the air cell based on providing space for macro inspection (up to 30X) of a specimen bundle and individual fuel pins. This type of examination will require the traversing of the specimen past the objective lens of a stereo viewer. For a 4-1/2 ft long specimen, a minimum of $7 \mathrm{ft}$ would be required. The remaining floor space within the hot cell will be required for a balance, a gamma pickup head within a shielded container, electrical resistivity, eddy current, and ultrasonictesting equipment.

In addition to the above mentioned equipment, floor space will be required for two access plugs and a wash pit for loop decontamination.

Like cell Number 1, the size of hot cell Number 2 (argon atmosphere) was estimated on the basis of the work that has to be done in it. The $16 \mathrm{ft}$ long by $8 \mathrm{ft}$ wide floor area was based on providing space for the following operations: 
1 - Cutting off, replacing and welding the loop pressure tube.

2 - Cutting off, replacing and welding the loop containment tube.

3 - Removing specimens from loops.

4 - Reinserting specimens into loops.

5 - Removing liquid metal from specimens and loops.

6 - Filling loops with liquid metal.

7 - Opening, attaching to, and seal welding the helium and liquid metal fill lines at the upper end of the loop.

8 - Puncture of individual fuel pins and the collection of fission gas.

9 - Resealing fuel pins.

10 - Inspection of all welds.

While many of the above operations can be combined and per formed with multi-purpose equipment, the exact nature and size of the equipment will require Title I design and research and development effort.

Floor area will also be required for an access plug, work pit and storage pits.

A sixteen foot long cell will also provide the capability for hanAling a loop in a horizontal position should the need a rise.

\section{Facility Layout}

The facility has been designed to be consistent with standard hot cell procedures and practices and to provide sufficient working space within the allocated area.

The two concepts shown differ mainly in the placement of the hot cell with reference to the wall of the ATR building. The hot cells are identical in size and configuration and the working spaces of both plans having approximately the same floor area.

Since the two schemes are similar in design and cost*, one does not have any major advantages. Scheme Number 2 is recommended on the basis of the following secondary considerations:

*A preliminary comparison of both schemes indicates that the cost dif ferential between the two is negligible. 
1 - The canal passes through the warm area.

2 - The canal is approximately $8 \mathrm{ft}$ shorter.

3 - There is a better utilization of available space throughout the building.

4 - The traffic pattern is simpler.

5 - The floor of the hot cells is at the same level as the floor level of the warm working a rea.

6 - By increasing the length of the building, the size of the hot cells can be lengthened if the Title I study indicates that additional space is required.

The one disadvantage with the recommended design is that the canal contains a right angle turn, but this is not considered a major handling problem.

\section{REFERENCES}

1 - USAEC-IDO Letter ECE:MEA, H M Leppich to R H Gordon, March 8, 1962

2 - Record of telephone coversation from M E Audio, IDO; W C Hayden, IDO; T E Hopkins, IDO; to J A Scarola, Ebasco; Ebasco File No. I-C-3.4, March 22, 1962

3 - Babcock \& Wilcox Design Data Sheet R-6003, May 18, 1962

4 - USAEC-IDO Letter RTR: J C Mc, H M Leppich to R H Gordon, April 20, 1962 


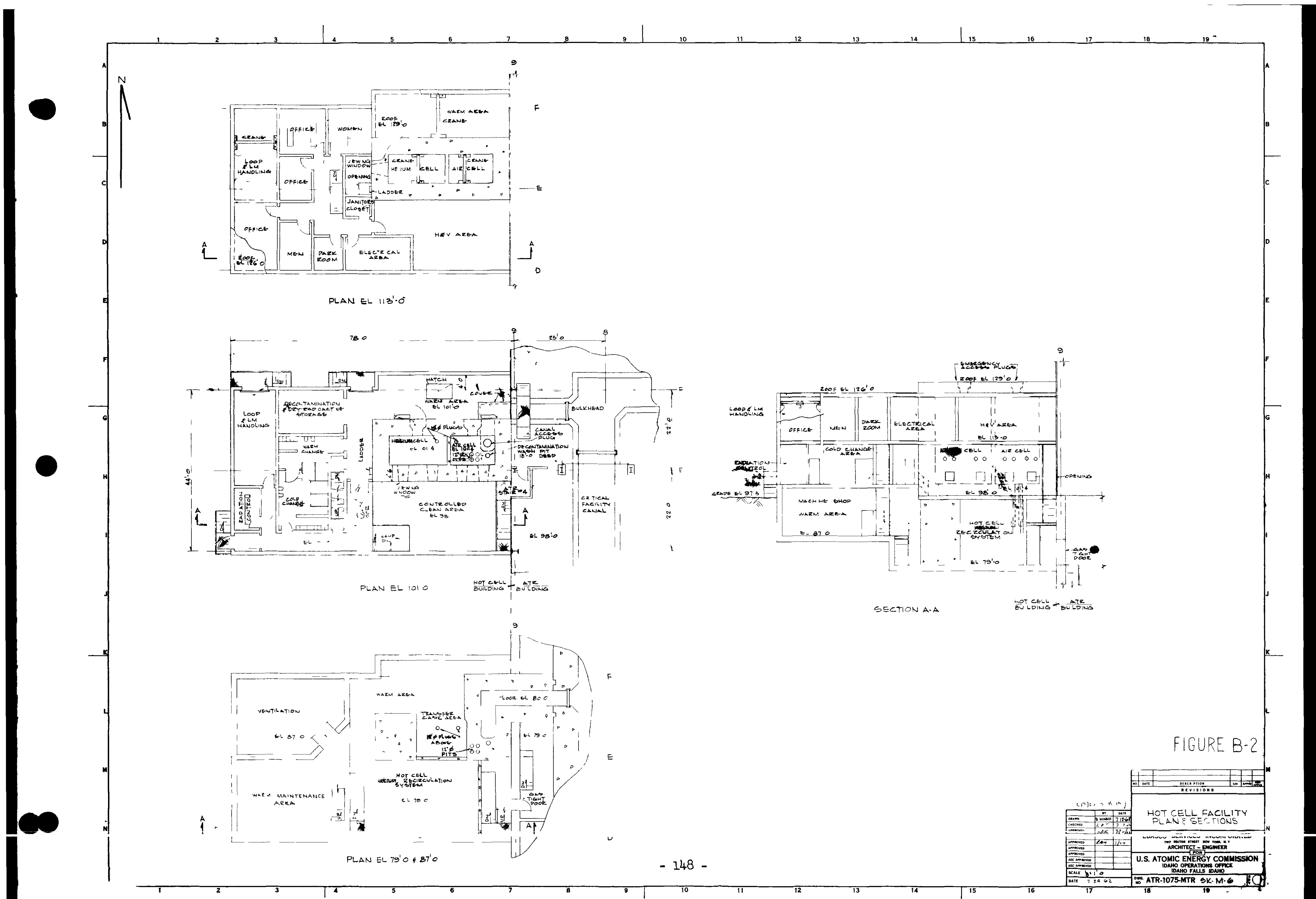




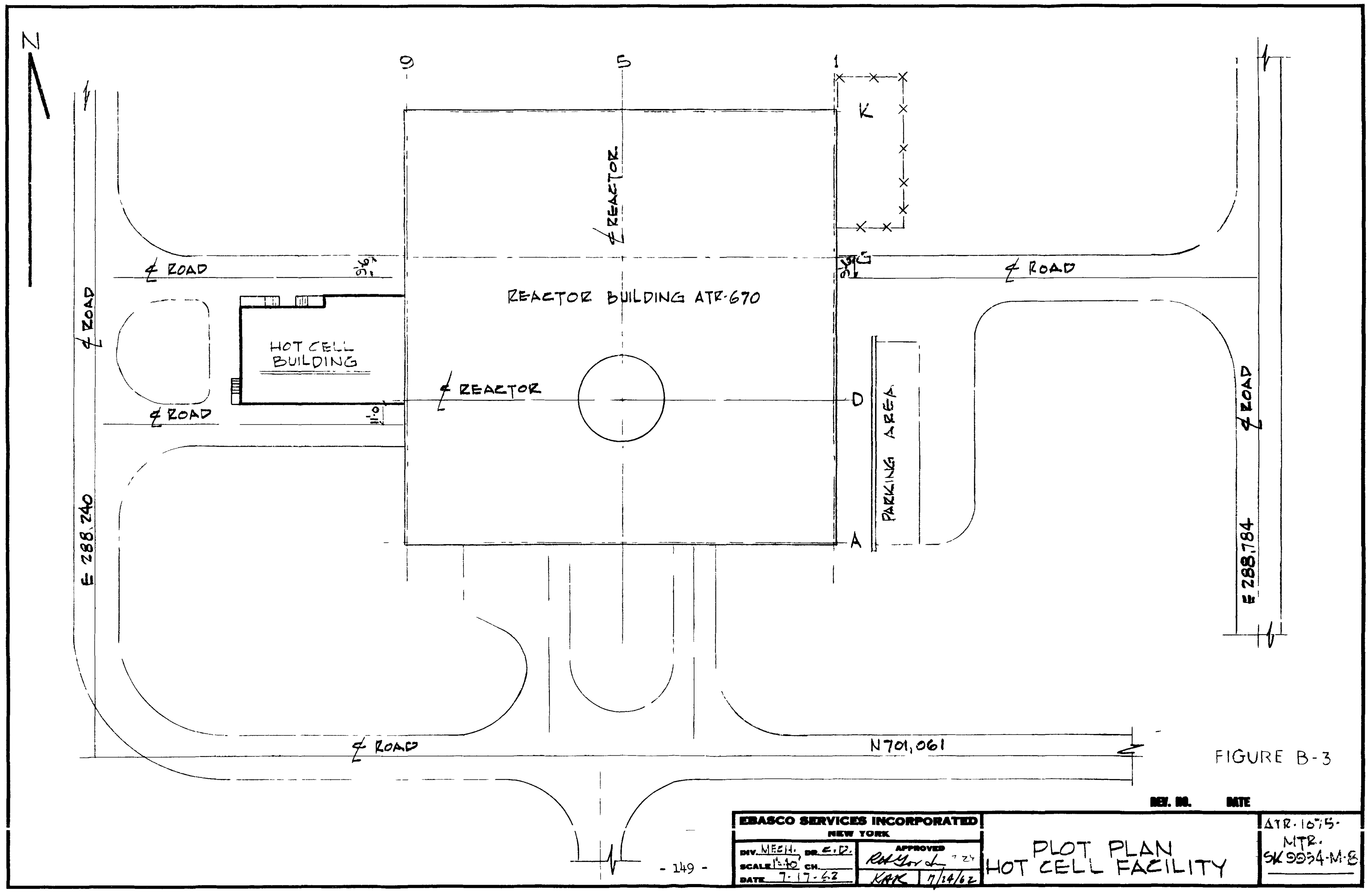


$$
\text { . }
$$ 
APPENDIX C

Hot Cell Facility Liquid Metal

Systems 
0 - 
Design Data Sheet No. M-6003

EO-AEC - 9954

Contract No. AT(10-1)-1075

October 15, 1962

L. Berkowitz (UNC)/D. Rosh (UNC)

\section{EBASCO SERVICES INCORPORATED \\ ADVANCED TEST REACTOR-DESIGN DATA \\ LIQUID METAL LOOP FACILITIES \\ HOT CELL FACILITY LIQUID METAL SYSTEMS}

\section{PUR POSE \& SCOPE}

This data sheet presents the functional requirements and conceptual designs for the ATR Hot Cell Facility Liquid Metal Systems.

\section{SUMMARY}

The functional requirements of the liquid metal systems are summarized in the following table:

\begin{tabular}{|c|c|c|c|c|c|c|}
\hline \multirow{2}{*}{$\begin{array}{c}\text { System } \\
\text { Location }\end{array}$} & \multirow{2}{*}{$\begin{array}{c}\text { Loop } \\
\text { To Be } \\
\text { Serviced }\end{array}$} & \multirow{2}{*}{$\begin{array}{c}\text { Liquid } \\
\text { Metal } \\
\text { Handled }\end{array}$} & \multirow{2}{*}{$\begin{array}{l}\text { Condi - } \\
\text { tion of } \\
\text { Loop }\end{array}$} & \multirow[b]{2}{*}{ Specimen } & \\
\hline & & & & & Function & Operation \\
\hline
\end{tabular}

Liquid Metal

Handling

Area Fast Flux $\mathrm{NaK}(44 \% \mathrm{~K})$

New

Purify NaK

New Fill Loop

Batch

Liquid Metal

Handling Thermal

Area Flux $\mathrm{Na}$

New New Purify Na

Batch

Sub Cell

Wa rm

Area

Fast Flux $\mathrm{NaK}(44 \% \mathrm{~K})$

New

Irradiated

Fill Loop

Batch

Sub Cell

Thermal

Warm

Flux

$\mathrm{Na}$

New or

New or

Fill Loop,

Area

Irradiated Irradiated

Purify $\mathrm{Na}$,

Clean Loop

Remote

Batch;

Continuous *

Recirculation,

Remote

* The operational feasibility of the $\mathrm{Na}$ recirculation system will have to be demonstrated in an operational mock-up. 
Design Data Sheet No. M-6003

Liquid Metal Loop Facilities

Hot Cell Facility Liquid Metal Systems

October 15,1962

3. LIQUID METAL HANDLING AREA SYSTEMS

\subsection{System Descriptions}

The systems required for servicing of new Fast and Thermal Flux Loops when containing unirradiated specimens will be located in the liquid metal and loop handling area within the Hot Cell Facility (Ref 1). The systems for Sodium (Na) and Sodium-Potassium Alloy $(\mathrm{NaK})$ are, in principle, identical and are illustrated schematically in an elementary flow diagram (Fig. C - 1) that is appropriate to each of them.

The system will contain the following components:

1. Liquid Metal Purification Tank

2. Fill Tank

3. Aging Tank ( $\mathrm{Na}$ System only)

4. Helium supply

5. Vacuum Pump

6. Interconnecting Valves, Piping and Fittings

7. Trace Heaters (Na System only)

8. Instrumentation

\subsection{Operation}

The systems have been designed to receive liquid metal (as shipped by the manufacturer) and pass it through batch process purification tanks into a fill tank. The fill tank can be left in the system for initial liquid metal loop filling, or removed for use in the sub cell warm area systems. The liquid metal will be transferred through the system by use of differential cover gas pressure between the transfer points.

The $\mathrm{Na}$ will be received in bulk form and introduced into the aging tank where it will be maintained at $230 \mathrm{~F}$ for approximately 3 days. After the initial aging purification the liquid metal will be transferred to the purification tank which contains a bed of zirconium or titanium chips. The tank and its contents will be maintained at $1400 \mathrm{~F}$ for a period of time sufficient to insure completion of the gettering reactions. The purified batch will then be transferred to the fill tank for storage or filling a loop.

The loops will be filled with the required quantity of liquid metal by designing the fill tanks to transfer only a predetermined amount to the loops.

To prevent freezing of the Na during a transfer or loop filling operation, the liquid metal and all system components will be maintained at a minimum temperature of $300 \mathrm{~F}$.

The helium supply and vacuum systems are provided to establish both the pressure differentials required for liquid metal transfer and the desired cover gas atmosphere in the system. The helium will 


\subsection{Operation (Cont'd)}

be purified by passing it through a scrubber system. The gas will be bubbled through a column scrubber containing stainless steel mesh located above $600 \mathrm{~F} \mathrm{NaK}$. The purified gas will then be passed through a second column scrubber containing stainless steel mesh over cold NaK. Any NaK vapor carried over in the purified gas stream will be removed in a final vapor trap.

The NaK fill system for use on Fast Flux Loops will be identical to the sodium system except that the aging tank, trace and loop heaters will not be used.

\section{SUB-CELL WARM AREA NaK SYSTEM}

\subsection{System Description}

The Sub-Cell Warm Area NaK System (Fig. C-2)will be used for filling new Fast Flux Loops containing irradiated specimens. The equipment will be designed for remote operation and will be located in the warm area beneath the hot cell. Interconnecting piping to the loop (within the hot cell) will penetrate the hot cell floor through special service plugs.

The system will contain the following equipment:

1. Fill Tank

2. Helium Supply

3. Vacuum Pump

4. Interconnecting Valves, Piping and Fittings

5. Instrumentation

\section{$4.2 \quad$ Operation}

The fill tank will contain a predetermined quantity of $\mathrm{NaK}$ purified in the liquid metal handling a rea system. The NaK will be further purified before filling a loop by aging in the fill tank at $400 \mathrm{~F}$ for 24 hours and then cooling to room temperature.

The NaK will be transferred into the loop through the use of differential cover gas pressure between the two points. The amount of liquid metal transferred to a loop will be controlled by the predetermined quantity and height of the fill line within the fill tank.

The helium supply and vacuum systems will be identical to the systems described in section 3.2 .

\subsection{Fill Procedure}

The design of the Fast Flux Loop (PW -19) and the decay heat generation of an irradiated specimen will require that the loop be partially filled by displacement of the inert gas within the loop. To

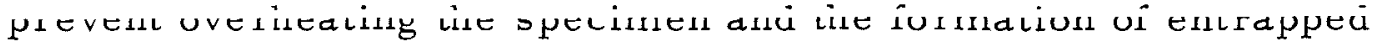
gas pockets within the loop a combination of gas displacement and vacuum filling will be used. 
Design Data Sheet No. M-6003

Liquid Metal Loop Facilities

Hot Cell Facility Liquid Metal Systems

October 15, 1962

\subsection{Fill Procedure (Cont'd)}

The loop will be filled by displacement of gas until the specimen has been submerged. The loop can then be evacuated and filling completed. The amount of liquid metal required for each operation can be predetermined by using two NaK lines at different levels within the fill tank.

5. SUB-CELL WARM AREA Na SYSTEM

\subsection{System Description}

The sub-cell warm area $\mathrm{Na}$ system (Fig. C-3) will be used for filling a new Thermal Flux Loop containing an irradiated specimen, or an irradiated Thermal Flux Loop containing either a new or irradiated specimen. The equipment will be designed for remote operation and will be located in the sub-cell warm area. Interconnecting piping to the loop will penetrate the hot cell floor through special service plugs.

The system has been designed to purify the $\mathrm{Na}$ within a thermal loop through the use of an external circulating loop containing the following equipment:

1. Fill Tank

2. EM Pump

3. EM Flowmeter

4. Hot Trap and Cold Trap

5. Preheater

6. Regenerative heat exchanger

7. Sodium to air heat exchanger

8. Interconnecting Valves, Piping and Fittings

9. Trace heaters

10. Loop heaters

11. Helium Supply

12. Vacuum System

13. Instrumentation

14. Expansion Tank

\section{$5.2 \quad$ Operation}

\subsubsection{New Loop}

The filling of a new loop will only require use of the fill tank, with the external purification system valved off. The system in this configuration is identical to the batch system shown in Figure $\mathrm{C}-2$. The loop will be 


\subsubsection{New Loop (Cont'd)}

filled by use of differential cover gas pressure. The operation of this part of the system will be identical to the NaK system described in section 4.2 with the exception that the liquid metal and system components will be maintained at a minimum temperature of $300 \mathrm{~F}$ during transfer.

\subsubsection{Irradiated Loop}

The Na circulation system will be used to remove oxide contamination from an irradiated Thermal Flux Loop. The purification system will be designed to circulate $\mathrm{Na}$ at a flow rate of 0.5 to $1 \mathrm{gpm}$. Purification will be accomplished by cold trapping at $250-300 \mathrm{~F}$ and by hot trapping at $1500 \mathrm{~F}$ in a reactor packed with titanium, zirconium or other suitable materials. The direction of flow has been chosen to prevent the plugging of critical flow paths within the thermal loop. During in-pile operation of the loop the sump will act as a cold trap and collect most of the oxide. The Na flow directly out of the loop from the sump will prevent the oxide from being carried down through the pump shaft annulus and heat exchanger.

During purification the thermal loop will be maintained at the maximum allowable temperature. The external line from the loop sump to the purification system will be maintained at a temperature higher than the loop to prevent plugging.

\subsection{Fill and Operating Procedures}

\section{$5.3 .1 \quad$ New Loop}

The fill procedure for a new thermal loop containing an irradiated specimen is identical to the $\mathrm{NaK}$ system described in section 4.3 .

\subsubsection{Irradiated Loop}

Conceptually, the $\mathrm{Na}$ circulation system will be filled and operated in the following manner.

1. The thermal loop is preheated and filled by differential cover gas pressure (between the fill tank and the loop) until the proper level is obtained as indicated by a Na level detector.

2. The pressure in the the rmal loop is increased

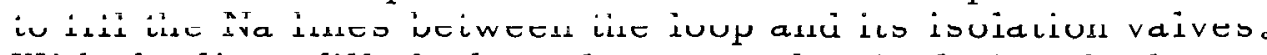
With the lines filled, the valves are shut isolating the loop. 
3. The purification loop is preheated and pressure filled.

4. The purification loop pump is turned on circulating the $\mathrm{Na}$. The components a re brought up to temperature, allowing the rmal expansion of the coolant to be taken up in the expansion tank.

5. The expansion tank is valved off, the the rmal loop bypass valve closed, and the loop isolation valves opened initiating circulation through the the rmal loop. With the expansion tank valved off the thermal loop sump acts as an expansion tank.

6. Circulation through the system is continued for a period of time sufficient to insure completion of the purification process.

7. Circulation is stopped and all the liquid metal valves are closed.

8. The sump and expansion tank valves and circulating loop shut-off valve (v1) a re opened, and the $\mathrm{Na}$ within this part of the system pressurized back into the fill tank.

9. The thermal loop isolation valve $(\mathrm{v} 2)$ is opened and the pressures adjusted so that the $\mathrm{Na}$ remaining in this fill line drains into the loop.

10. Isolation valve (v2) and the expansion tank valve are closed, and second thermal loop isolation valve and loop bypass valve are opened.

11. The loop cover gas pressure is increased over that of the fill tank and the excess $\mathrm{Na}$ will be "blown" back into the fill tank. By predetermining the height of the fill line in the thermal loop sump, the desired liquid level will be established.

6. ANALYSIS

6.1 Liquid Metal Purity

The purification systems shown in this data sheet have been based on the requirements of high purity liquid metal for satisfactory loop operation as presented in reference 1. While the maximum tolerable impurity level within the loop primary coolant cannot be determined, Pratt \& Whitney experience with loop bench tests and PW-19 loop operation indicates that the oxide concentration must be kept to a low level. 


\subsection{Liquid Metal Purity (Cont'd)}

The purity of the liquid metal within the system will be dependent on the design and size of the system, the fabrication technique, and the operating procedures. With reasonable care, the batch purification systems can supply liquid metal with oxide concentrations of 5 to $10 \mathrm{ppm}$. Because of the many components and unknown operating conditions, the purification capabilities of the circulating $\mathrm{Na}$ system will have to be determined in an operational mock-up.

\subsection{System Operation}

\subsubsection{Batch NaK System}

The operation of the batch purification and fill system for a new Fast Flux Loop with a new or irradiated specimen does not present any major problems. The components located in the sub-cell warm area will require remote operation, while those components within the hot cell will have to be designed for remote or manipulator operation.

\subsubsection{Batch $\mathrm{Na}$ System}

The operation of the batch purification and fill system for a new Thermal Flux Loop with a new or irradiated specimen will be similar to that of the NaK system with the additional requirement that all components be kept above the $\mathrm{Na}$ melt temperature.

The feasibility of using the batch system filling technique for a new the rmal flux loop containing an irradiated specimen will be dependent on:

1. The ability of maintaining all parts of the thermal loop above the $\mathrm{Na}$ melt temperature while cooling the in-core portion to prevent overheating of an irradiated specimen (Ref 2).

2. The ability to remove all $\mathrm{Na}$ from an ir radiated specimen (Ref 1 ) prior to insertion in a new loop. If the specimen cannot be cleaned the circulating Na purification system will have to be used.

\subsubsection{Circulating Na System}

The circulating $\mathrm{Na}$ system to be used for an irradiated thermal loop is much more complex in design and operation than any of the other systems, and presents many unknown factors which affect its operational feasibility. 


\subsubsection{Circulating $\mathrm{Na}$ System (Cont'd)}

The satisfactory operation of the purification system will be dependent on:

1. The ability to circulate $\mathrm{Na}$ through the small thermal loop fill lines (1/4" O.D.) and restricted internal passages without plugging.

2. The ability of heating the thermal loop to at least $400 \mathrm{~F}$ while cooling the in-pile section of the loop (Ref 2).

3. The ability of remotely opening, connecting to, and resealing the thermal loop fill lines.

4. The longevity and accuracy of the thermal loop liquid level detectors.

5. The impurity level within the the rmal loop prior to purification.

The complexity of the system and operational problems presented will require an operational mock-up to demonstrate feasibility.

7. REFERENCES

1. Ebasco Services Inc. Design Data Sheet M-6001, June 27, 1962

2. Babcock \& Wilcox Design Data Sheet R-6011 


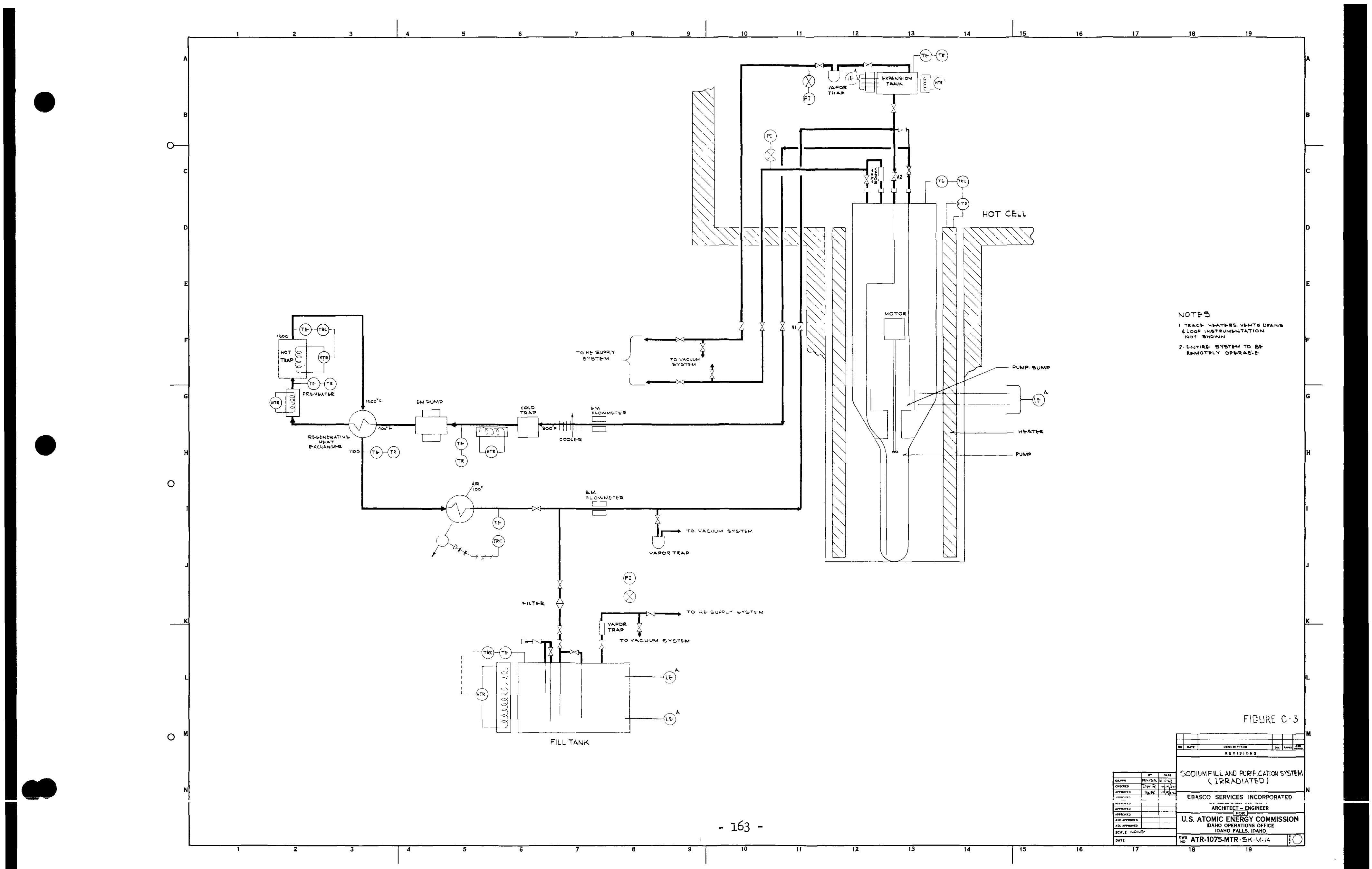


$$
\text { . }
$$ 
APPENDIX D

Hot Cell Facility Inert Atmosphere Systems 
Design Data Sheet M-6004

EO-AEC - 9954

Contract No. AT(10-1)-1075

October 1, 1962

L. Be rkowitz (UNC)/D. M. Rosh (UNC)

\section{EBASCO SERVICES INCORPORATED \\ ADVANCED TEST REAC TOR -DESIGN DATA \\ LIQUID METAL LOOP FACILITIES}

HOT CELL FACILITY INERT ATMOSPHERE SYSTEMS

\section{PURPOSE AND SCOPE}

This design data sheet discusses the systems required to provide and maintain an inert atmosphere within the hot cells of the ATR Hot Cell Facility.

The conceptual design of the Hot Cell Facility has been presented in Design Data Sheet 6002 "Fast and Thermal Flux Loops - Hot Cell Facility". However, the status of the Liquid Metal Loop Facilities Program is such that the nature of the operations to be carried out in the hot cells and the physical size of the cells are being re-evaluated. As a consequence, the systems presented in this data sheet are of a general nature and consider only the design characteristics required to satisfy the probable alternative Hot Cell Facility functional requirements.

\section{DESIGN BASIS}

The Hot Cell Facility Inert Atmosphere Systems will be required to:

a) Provide and maintain an atmosphere of purity suitable for carrying out the operations scheduled for performance with in the hot cell.

b) Maintain the pressure within the cell at a level that is negative with respect to the surroundings.

c) Maintain the temperature within the cell at a suitable level.

The capacity of the systems will be mainly a function of (a) the cell volume, (b) inert atmosphere, (c) atmosphere purity requirements, (d) heating loads and (e) probable inleakage.

The basis for the conceptual design of the systems presented in this report is summarized in Table I.

Table I - Conceptual Design Basis of the ATR Hot Cell Facility Inert Atmosphere System.

Cell Volume

Cell Pressure

Cell Temperature

Cell Inleakage

Cell Atmospheres

Atmosphere Impurity Concentration:

Oxuern

Water Vapor

Nitrogen

$$
\begin{aligned}
& \text { TBD } \\
& -0.5^{\prime \prime} \text { to }-6^{\prime \prime} \mathrm{wg} \\
& 80 \text { to } 105 \mathrm{~F} \\
& 1 \text { cfh } \\
& \text { Argon/Helium } \\
& \text { 3n rma } \\
& 10 \mathrm{ppm} \\
& \mathrm{TBD}^{2}
\end{aligned}
$$


Heating Load:

Lighting

Fast Flux Specimen

T BD

Thermal Flux Specimen

Miscellaneous

Inert Gas Circulation Rate

$0.5 \mathrm{KW}\left(2 \frac{1}{2}\right.$ weeks after shutdown)

$2.5 \mathrm{KW}$ ( 5 weeks after shutdown)

TBD

TBD

Notes:

1 - TBD - To be determined

2 - Nitrogen removal will be required for handling refractory metal clad fuel specimens.

3. SYSTEM DESCRIPTION

\subsection{General}

The Inert Atmosphere Systems will consist of the following:

a) Main Circulation System which maintains cell temperature and pressure within the desired limits.

b) Purification System which maintains oxygen, water vapor, and nitrogen concentrations in the cell atmosphereat or below specified levels.

c) Filtration System which removes particulate matter, in the submicron size range, from the cell atmosphere.

d) Vacuum System which is used to evacuate the cell transfer cask and locks.

e) Inert Gas Supply System for cell filling and system make-up.

f) Iodine Removal System which is provided for cleanup of the cell atmosphere in the event of accidental release of volatile fission products.

g) Instrumentation Systems.

Elementary flow diagrams for the main circulation system and auxiliary subsystems are presented in Figures D-1 through D-7 and are discussed in the following sections.

The nature of the inert atmosphere to be maintained within the hot cells will be dependent upon the kind of specimens and the operations to be carried out within the cells. In general, if all the specimens to be handled are stainless steel clad, then nitrogen, argon or helium of acceptable purity would serve as suitable inert atmospheres. However, the Hot Cell Facility will require the capability of handling refractorymetal clad specimens as well as stainless clad (Ref. 1), and therefore only argon or helium of acceptable oxygen, nitrogen and water vapor concentrations will be suitable. 
For general loop handling within the hot cell either of the three inert gases would be satisfactory. However, for reinsertion of an irradiated specimen into a loop, only helium will be satisfactory (Ref. 1). This requirement is based on the need to minimize the decay time before a specimen can be reinserted in a loop, (Ref, 2, 3) and the superior heat transfer properties of helium.

The inert atmosphere required, based on loop and specimen handling, is summarized in Table 2 .

Table 2 - Hot Cell Inert Gas Atmosphere.

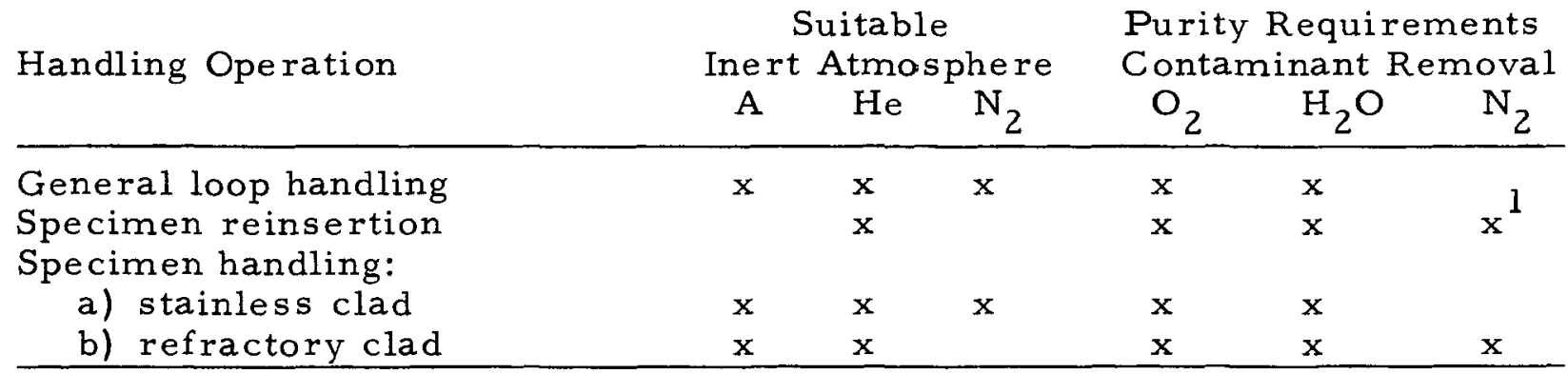

$1-N_{2}$ removal will be required when handling refractory-metal clad specimens.

Relative to the nature of the process equipment required to handle nitrogen, argon and helium, the following remarks are pertinent:

1 - Process equipment suitable for handling argon will also handle nitrogen, but will not be suitable for helium.

2 - Helium, because of its low density, is more difficult to circulate than argon or nitrogen. Helium circulation equipment is more complex and costly.

3 - Process equipment required for oxygen, water vapor, and nitrogen removal is larger, more complex, costlier and more difficult to operate and maintain than that required for removal of oxygen and water vapor only.

4 - Helium is more difficult to contain than either argon or nitrogen, and is more costly.

\subsection{Main Circulating System}

The primary function of the main circulation system (Fig. D-1) is to maintain the pressure within the cell at a level that is negative with respect to atmospheric pressure over the range of anticipated heat loads and inleakage. The maintenance of cell temperature at any particular value, provided it is within the allowable temperature range, is of secondary interest.

Two factors affect the pressure within the cell: 1) Heat Load and

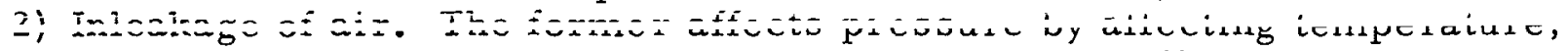
the latte $r$ by increasing inventory. Quantitatively, the effect of a temperature 
change of $1 \mathrm{~F}$ will be a pressure change of approximately $0.6^{\prime \prime} \mathrm{H}_{2} \mathrm{O}$. The effect of inleakage for various size cells is shown in Figure D-2. The inleakage of air to increase the cell pressure by $0.5^{\prime \prime} \mathrm{H}_{2} \mathrm{O}$ will range from approximately $3 \mathrm{cu}$. $\mathrm{ft}$. for a $2000 \mathrm{cu}$. $\mathrm{ft}$. cell to approx. $7-3 / 4 \mathrm{cu}$. $\mathrm{ft}$. for a $5000 \mathrm{cu}$. ft. cell. Since the inleakage will probably be on the order of $1 \mathrm{cu}$. $\mathrm{ft} . / \mathrm{day}$, small decreases in cell temperature can be used to counteract the pressure increasing effects of inleakage.

Without any other form of control the inventory within the system would build up to a point where the cell pressure would be at the maximum allowable with the cell temperature at the lower limit. This condition would prevent compensating for additional inleakage. To overcome this limitation, additional control will be obtained by reductions of the system inventory through controlled use of the transfer locks and periodic bleedoff to the facility exhaust stack.

The design features of the main circulation system which permit the desired pressure control are:

1 - The pressure everywhere within the system will be negative with respect to the surroundings.

2 - Cell temperature will be varied to accommodate inleakage and changes in heat load.

The system illustrated in Figure D-1 consists of two identical loops installed in parallel and will be designed to maintain the cell at a nominal pressure of $-2^{\prime \prime} \mathrm{H}_{2} \mathrm{O}$ at 80 to $105 \mathrm{~F}$. Each loop will consist of a roughing filter located within the cell, blower, cooler, and associated dampers and ducting. The system will have the following capability:

Gas:

Circulation Rate:

Gas Temperature at Cell Inlet:

Loop Pressure Drop:
TBD

$\mathrm{TBD}$

7OF (nominal)

TBD

The loops will be operated independently or simultaneously as re quired to maintain the pressure within the desired range. The loop components are described below:

\subsubsection{Blower}

Circulation of the cell atmosphere through the main circulation system will be accomplished with identical high volume, low head centrif ugal blowers located in each loop. The units will be completely enclosed with the power leads hermetically sealed into the outer container. The type of unit will be dependent on capacity and pressure rise required.

\section{2 .2 Cooler}

The inert gas circulated through each loop (Figure D-1) will be cooled in separate refrigeration system coolers. The coolers will be finned tube heat exchangers with the inert gas flowing on the shell side and refrigerant in the tubes. The cooler will be designed to minimize the possibility of having refrigerant leakage into the inert gas stream. The tubes which will be in a leak tight shell will be designed so that they do not contain any welds or joints within the shell. 


\subsubsection{Filter}

Filtration within the main circulating system is required for removal of atmospheric dust and particulate matter in the submicron size range in order to minimize the spread of contamination to ducting and components outside the cell. Ideally, roughing filters and "absolute" filters should be located immediately adjacent to the hot cell.

As shown in Figure D-1, the roughing filters have been placed in the main circulating system while the "absolute" filters have been tentatively located in a bypass filtration loop. Based on the circulation rate required for an inert gas hot cell of the size shown in DDS-M-6002 (3200 cu. ft.) a single "absolute" filter would produce an excessive pressure drop, while multiple filters in parallel located adjacent to the hot cell would present problems of space requirements, installation and removal. The final location of the "absolute" filter will have to be determined by the flow rate and available pressure drop.

The design of the cell and the main circulation system will, however, accommodate roughing filters in each loop located at the cell discharge. These filters can be readily replaced remotely from within the cell. The filters will be of the fiberglass cartridge type and have an efficiency of approximately $95 \%$ as measured by the NBS discoloration test. Their location will prevent the spreading of gross contamination outside the cell in a manner comparable to that of many hot cell installations.

\subsubsection{Dampers}

The dampers will be remotely operated butterfly valves with resilient valve seats. The valve stem will be sealed with a lantern ring and a double set of packing. The space between the inner and outer stem sealings will be pressurized with inert gas to prevent leakage of the main circulating gas to the atmosphere.

\subsubsection{General System Design Features}

The following design features are independent of the inert gas and the size of the system:

1. The duct work will be fabricated from type 304 stainless steel, or stainless clad material, and will be of all welded construction. The duct work shall be capable of withstanding full internal vacuum with atmospheric external pressure.

2. Ducting shall be fabricated with a leak tightness of $10^{-5}$ atmosphere-cc/sec as determined by standard helium leak testing techniques.

3. Resilient seated isolation dampers will be provided to isolate the cell, and individual components within the loops. Provisions will be made for evacuating, and backfilling sections between dampers with inert gas.

4. Materials of construction used for fabrication of blowers, coolers and dampers may be manufacturers' standards. The component assemblies will be required to meet the tentative leak tightness given in item 2 . 
5. All lubricants will be of the low vapor pressure type with all bearings being presealed.

\subsection{Purification System}

The purification system to be provided will be dependent upon the type of specimens to be handled in the Hot Cell Facility.

If only stainless steel clad specimens are to be handled, then the system need remove only oxygen and water vapor from the inert gas. The system is illustrated schematically in Figure D-3 and described in section 3.3 .1 .

If on the other hand, refractory-metal clad specimens are to be handled, then the system must be designed to remove nitrogen as well as oxygen and water vapor. The feasibility of handling refractorymetals will be dependent on the maximum allowable contamination levels (cladding at $1000 \mathrm{~F}$ ) in the inert gas and the ability to maintain this purity within the hot cell atmosphere. The system required to remove all three contaminants is shown in Figure D-4 and described in section 3.3 .2 .

Both purification systems have been designed as bypass loops. However, the final location and size will be dependent on the following parameters:

1 - Main system circulation rate.

2 - Available pressure drop.

3 - Inleakage into cell.

4 - Purity of gas leaving the cell.

3.3.1 Purification System for $\mathrm{O}_{2}, \mathrm{H}_{2} \mathrm{O}$ Removal

As shown in Figure 3 , the purification system will consist of a gas booster, aftercooler, oxygen removal unit and a dual unit absorption dryer.

\subsubsection{Gas Booster}

The gas booster will be used to circulate the inert gas through the purification train. The unit will be completely enclosed with the power leads hermetically sealed into the outer container. Lubricants will be of the low vapor pressure type, and bearings will be presealed. The gas booster will be required to operate under the following conditions:

Inert Gas:

Circulation Rate:

Inlet Pressure:

Gas Temperature:

Total Developed Head:
TBD

TBD

$-1 "$ to $-2 " \mathrm{H}_{2} \mathrm{O}$
$80-105 \mathrm{~F}$

$\mathrm{TBD}$ 


\subsubsection{Aftercooler}

The aftercooler will be located downstream of the gas booster. It is provided mainly to remove the heat of compression and the heat dissipated by the gas booster motor that is transferred to the circulating gas stream. It will be required to be capable of the following performance:

$\begin{array}{ll}\text { Rating: } & \text { TBD } \\ \text { Inert Gas: } & \text { TBD } \\ \text { Gas Inlet Temperature: } & \text { TBD } \\ \text { Gas Outlet Temperature: } & 80 \mathrm{~F} \\ \text { Primary Side Pressure } & \\ \text { Drop: } & \text { TBD } \\ \text { Heat Sink: } & \text { Well Water }\end{array}$

The need for the aftercooler is based on the operating characteristics of the dryer; the absorption capacity of the solid desiccants varying inversely with temperature.

\subsubsection{Oxygen Removal Unit}

A commercial catalytic conversion unit (Deoxo) will be provided for removal of oxygen from the gas stream. In this unit, the oxygen in the inert gas reacts with an essentially stoichiometric quantity of hydrogen to form water vapor. The catalyst for the reaction consists of a bed of palladium supported on pelleted activated alumina.

At flow rates up to $200 \mathrm{scfh}$ the units are designed to remove up to $3 \%$ oxygen, and up to $1 \%$ oxygen at flow rates of 400 to $20,000 \mathrm{scfh}$. The purified gas leaving the unit will contain less than 1 ppm oxygen.

The method of control supplied with the commercial unit operates by sampling the hydrogen content of the gas stream leaving the reactor. With this control mode the residual hydrogen in the purified gas will be approximately $0.1 \%$. Another method of control is in use at the EBR II Fuel Cycle Facility in which the amount of hydrogen introduced into the reactor is governed by the catalyst bed temperature. The method of control to be used for this facility will be determined during Title I.

\subsubsection{Dryer}

The dryer will be a twin bed molecular sieve unit. Each bed will be sized to have the capacity for removing the water vapor introduced into the inert gas atmosphere from anticipated cell inleakage and from generation in the oxygen removal unit. The gas leaving the dryer will have water vapor content equivalent of $-100 \mathrm{~F}$ dewpoint.

The size of the unit will be consistent with an absorption time of not less than one week. An open cycle will be employed for regeneration with air used as the regenerant.

\subsubsection{Materials of Construction}

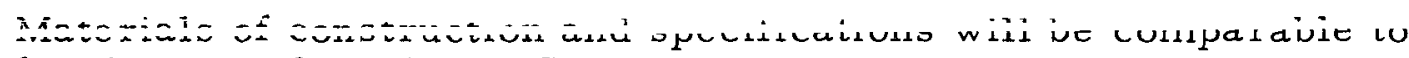
those for the Main Circulation System. 


\subsubsection{Purification System for $\mathrm{O}_{2}, \mathrm{H}_{2} \mathrm{O}$ and $\mathrm{N}_{2}$ Removal}

The purification system for removing nitrogen as well as oxygen and water vapor is based on the use of high temperature gas-solid gettering reactions and desiccant drying. The system as shown in Figure D-4 will consist of a gas booster, aftercoolers, preheater, regenerative heat exchanger, gettering reactors, and dual absorption dryer.

The units of this system which are not similar to components of the previous purification system are described below:

\subsubsection{Preheater and Regenerative Heat Exchanger}

The preheate $r$ and regenerative heat exchanger will be commercially available units and designed to provide the maximum operating economy and reliability. The units will be sized to the following requirements:

$\underline{\text { Preheater }}$

Rating: $\quad$ TBD

Voltage: TBD

Inert Gas: TBD

Gas Inlet Temperature: $80 \mathrm{~F}$ approx.

Gas Outlet Temperature: $850 F$ approx.

Regenerative Heat Exchanger

$\begin{array}{ll}\text { Rating: } & \text { TBD } \\ \text { Inert Gas: } & \text { TBD } \\ \text { Gas Inlet Temperature: } & 850 F \text { approx. } \\ \text { Gas Outlet Temperature: } & 1250 F \\ \text { Pressure Drop: } & \text { TBD }\end{array}$

\subsubsection{Gettering Reactors}

The oxygen and nitrogen within the gas stream will be removed by chemical reaction with a 50\% Titanium-50\% Zirconium gettering material. The gettering material will be in two columns designed to operate at $1250 \mathrm{~F}$ for oxygen removal and $1650 \mathrm{~F}$ for nitrogen removal. $1 /$ The columns will be sized for a superficial gas velocity of $=1$ foot $/ \mathrm{sec}$.

1. The design of the purification system for removing oxygen and nitrogen should be investigated during Title I. The system described above has been successfully used at the Carborundum Metals Corporation (ref.4). A system removing oxygen and nitrogen from argon with $50 \%$ Titanium $-50 \%$ Zirconium at $1470 \mathrm{~F}$ in a single reactor is used by the French Atomic Energy Commission (ref. 5). However, neither reference reports the final nitrogen concentration in the purified gas stream.

$-174-\quad D-8$ 


\subsection{Cooling System}

As previously noted the main control of the cell pressure will be by regulating the inert gas temperature. The cooling system will be required to provide complete control from the minimum basic heat load (no work being done in the cell) to the maximum anticipated heat load.

As shown in Figure $D-1$, cooling will be accomplished by two separate cooling systems. The systems will operate independently as well as simultaneously to provide the desired degree of cooling and control. The design of the coolant system will be dependent upon:

1 - The inert gas

2 - The heat load range

3 - Quantity of gas circulated

4 - Size of refrigeration compressors (number of stages of unloading)

\section{5 - Response time of the cooling system}

Conceptual designs for a chilled water and two direct cycle cooling systems are shown in Figures D-5, D-6 and D-7. In the first system, the inert gas will be cooled by chilled water circulating through the coils in the cooler, while in the direct cycle the cooling will be achieved by evaporation of $F$ reon refrigerant in the coils.

In all of the systems the cell pressure will be measured at a representative point by a differential pressure transducer. The output of the transducer will be fed into a pressure controlle $r$ which will regulate the amount of cooling. The cell temperature will also be measured at a representative point, and when either limit is reached the temperature signal will override the pressure control signal. The various control modes are shown in the following table:

Table 3 - Inert Gas Pressure - Temperature Control System

\begin{tabular}{|c|c|c|c|}
\hline \multicolumn{2}{|c|}{ Condition } & \multirow{2}{*}{ Control } & \multirow[t]{2}{*}{ Action } \\
\hline Pressure & Temperature & & \\
\hline$<-0.5^{\prime \prime} \&>-6^{\prime \prime}$ & $>80^{\circ} \&<105^{\circ}$ & Pressure & Cooling as reg. \\
\hline$<-0.5^{\prime \prime} \&>-6^{\prime \prime}$ & $\rightarrow 80^{\circ}$ & Temperature & $\begin{array}{l}\text { None - allow cell } \\
\text { temp to rise. }\end{array}$ \\
\hline$<-0.5^{\prime \prime} \&>-6^{\prime \prime}$ & $\rightarrow 105^{\circ}$ & Temperature & Cooling \\
\hline$\rightarrow-6^{\prime \prime}$ & $\rightarrow 80^{\circ}$ & $\begin{array}{l}\text { Temperature } \\
\text { and pressure }\end{array}$ & $\begin{array}{l}\text { Reduce inert } \\
\text { gas inventory }\end{array}$ \\
\hline$\rightarrow-0.5^{\prime \prime}$ & $\rightarrow 105^{\circ}$ & $\begin{array}{l}\text { Temperature } \\
\text { and pressure }\end{array}$ & $\begin{array}{l}\text { Increase inert } \\
\text { gas inventory }\end{array}$ \\
\hline
\end{tabular}

Note: Symbol $(\rightarrow$ ) denotes approaching limit given. 
The inert gas system will be designed so that either cooling system may be used with the second system in a standby position. When the heat load exceeds the capacity of the operating unit the standby system will be automatically actuated.

To prevent the introduction of water vapor or Freon into the inert gas stream, from a defective cooling coil, leak detectors will be used to isolate the cooling system. In the chilled water system water vapor detectors will be located upstream and downstream of the coolers and the inert gas monitored for a differential increase. The direct cycle systems will have Freon detectors located downstream of the coolers.

\subsubsection{Chilled Water System}

The chilled water system (Figure D-5) is designed for small capacity systems, but in general, is applicable to any size. In this system a fixed quantity of water is continuously refrigerated, mixed with the warm water from the inert gas cooler and stored in an insulated hold-up tank. The system will be controlled by regulating the temperature of the water entering the coil in the inert gas cooler. A three way modulating valve will bypass varying amounts of warm water leaving the cooler into the cold water stream returning to the cooler. The modulating valve will program the flow in accordance with the output signal from the pressure-temperature control system previously described.

\subsubsection{Direct Cycle - Inert Gas Bypass}

In the direct cycle system shown in Figure D-6, the cooling will be obtained by circulating Freon through the cooler. The required amount of cooling will be obtained by diverting controlled amounts of the circulating inert gas around the cooler. The flow of inert gas through the cooler and bypass will be controlled by a regulating system of opposed face dampers located upstream of the units. The position of the dampers will be set by a "damper operator" in response to the output signal of the hot cell control system.

Like the chilled water system this design is for small capacity systems, but is also applicable to all sizes.

\subsubsection{Direct Cycle - Multiple Coil}

The multiple coil system shown in Figure D-7 is basically applicable to systems with heating loads of approximately $30 \mathrm{Kw}$ and up. The system is designed to cool the inert gas by supplying refrigerant to individual coils within the cooler. The flow to each coil will be programmed by modulating control valves operating in different pressure ranges. As additional cooling is required, the increasing signal pressure, from the hot cell pressure temperature control system, will activate the required number of cooling coils. When all the coils in the system are being used and additional cooling is required, the control system will start inert gas flow through the second loop and actuate refrigerant flow through the proper number of cooling coils.

For uniform control the refrigeration compressor will have a minimum of four stages of unloading and will have flow control valves with overlapping operating ranges. 


\subsection{Iodine Removal System}

In the event that a fuel element fails while in the hot cell, or a fuel element which has failed is removed from a loop within the cell, volatile fission products will be released to the cell atmosphere. These will include particulate matter, rare gases and halogens. The half lives are of the order of $1.0^{3}$ seconds and more than 105 seconds for fission products such as $\mathrm{I}^{131}, \mathrm{Xe}^{133}$ and $\mathrm{Kr} 85$.

Since the cell cannot be evacuated to a pressure of less than approximately -6" $\mathrm{H}_{2} \mathrm{O}$, for structural reasons, the cell atmosphere cannot be pumped into a storage tank in which the fission products can be allowed to decay prior to release to the stack. Disposal of the fission products will, then, be accomplished in the following manner:

1. Particulate matter will be filtered out in the roughing filter and in the filtration system.

2. Halogens will be removed in an activated charcoal absorption system located downstream of the "absolute" filter as shown in Figure D-l.

3. Rare gases will be ultimately disposed of through the ATR stack. To accomplish this, the inert gas circulating system can be "opened" to the stack, as shown in Figure D-1, to permit sweeping out the cell atmosphere.

\subsection{Inert Gas Supply System}

The inert gas supply system will be required for cell atmosphere make-up and will consist of a manifold of high pressure gas cylinders. The quantity and size of the cylinders will be dependent on cell size and cell utilization, and shall be determined in Title $\mathrm{I}$.

\subsection{Auxiliary Gas Supply}

Auxiliary gas supplies will be required for the operation of pneumatic equipment located within the hot cell and pneumatic equipment and instru ments located outside of the hot cell.

\subsubsection{In-Cell Equipment}

A high pressure inert gas system will be required for the in-cell pneumatic equipment. The choice of a circulating system or a once-through system discharging into the cell will be dependent on the following factors and shall be determined during Title $\mathrm{I}$.

1. Quantity of equipment

2. Frequency of operation

3. Gas consumption rate

4. Effects on cell pressure 


\subsubsection{Out-of-Cell Equipment}

The auxiliary systems for out-of-cell equipment will use compressed air. The use of the ATR instrument air system or an independent hot cell facility system shall be determined during Title I.

\subsection{Vacuum System}

The vacuum system will be used for evacuating the hot cell transfer locks and cask, and for reducing the hot cell inert gas inventory. The sys tem will have the capacity of: (1) evacuating the largest transfer device to a pressure of $0.1 \mathrm{~mm} \mathrm{Hg}$ within one minute, and (2) reduce the cell pressure by $1 " \mathrm{H}_{2} \mathrm{O}$ within 1 minute.

\subsection{References}

1 - USAEC - IDO Letter RTR:JCMc, H. M. Leppich to R. H. Gordon, September 28, 1962 .

2 - Babcock and Wilcox Company Design Data Sheet R-6011, "Thermal Flux Liquid Metal Package Loop Decay Periods for Loop Handling".

3 - Babcock and Wilcox Company Design Data Sheet R-6007, "Fast Flux Liquid Metal Package Loop Decay Periods for Loop Handling", September 12, 1962 .

4 - Personal Communication K. Taylor (Carborundum Metals Corp) to L. Berkowitz (United Nuclear Corp), September 27, 1961.

5 - White, P.A.F. and Smith, S.E., "Inert Atmospheres", Butterworth \& Co. Ltd. (1962). 


\section{Appendix}

Preliminary design calculations for the inert gas system to be used with the hot cell shown in Design Data Sheet M-6002 had been started, and are being presented to indicate the size and type of equipment that would be needed for a 3200 cubic foot cell.

\section{$1 \quad$ Design Basis}

Cell Volume

$3200 \mathrm{Ft}^{3}$

Cell Pressure

Cell Temperature

Cell Inleakage

Cell Atmosphere

Specimen Cladding

Atmosphere Impurity Concentration:

Oxygen

Water Vapor

Heating Load:

Lighting

Fast Flux Loop

Thermal Flux Loop

Miscellaneous

Total

$-0.5^{\prime \prime}$ to $6^{\prime \prime} \mathrm{H}_{2} \mathrm{O}$

80 to $105 \mathrm{~F}$

$1 \mathrm{cfh}$

Argon

Stainless Steel

$30 \mathrm{ppm}$

$10 \mathrm{ppm}$

$4 \mathrm{Kw}$

$0.5 \mathrm{Kw}$

$2.5 \mathrm{Kw}$

13 (assumed)

$20 \mathrm{Kw}$

2 Main Circulation System

Argon Circulation Rate (each loop)

$1100 \mathrm{cfm}$

Argon Temperature at Cell Inlet

$70 \mathrm{~F}$ (nom.)

Pressure Drop (each loop)

Ducting Size

$2-1 / 4^{\prime \prime} \mathrm{H}_{2} \mathrm{O}$ (approx.)

Main Circulating Fans:

14 " Dia. or equivalent

Type: Hermetically sealed centrifugal blower

Size: $\quad 5 \mathrm{Hp}$

Developed Head: $2-1 / 4 " \mathrm{H}_{2} \mathrm{O}$

Roughing Filter:

Type: All glass filter medium

Size: $\quad 24^{\prime \prime} \times 24^{\prime \prime} \times 12^{\prime \prime}$

Pressure Drop: $0.4 " \mathrm{H}_{2} \mathrm{O}$

Efficiency:

$0.4^{\prime \prime} \mathrm{H}_{2} \mathrm{O}$
$90-95 \%$
(NBS Test)

Dampers:

Keystone Fig. 100 valve with modified stuffing box or equivalent

\section{Purification System}

Argon Flow Rate

Pipe Size

Gas Booster:

Argon Inlet Temperature

Argon Inlet Pressure

Total Developed Head

Type: Spencer "Hermetic"

size: o ip

$$
\begin{aligned}
& 100 \mathrm{cfm} \\
& 4 " \text { (approx.) }
\end{aligned}
$$

$80-105 \mathrm{~F}$

-1 " to $-2^{\prime \prime} \mathrm{H}_{2} \mathrm{O}$

3 psi 
Aftercooler:

Rating: $\quad 6000 \mathrm{BTU} / \mathrm{hr}$ (approx.)

Argon Inlet Temperature: $185 \mathrm{~F}$ (approx.)

Argon Outlet Temperature: $80 \mathrm{~F}$

Argon Pressure Drop: $10 " 1 \mathrm{H}_{2} \mathrm{O}$

Heat Transfer Surface $\quad 15 \mathrm{Sq}$. Ft. (approx.)

Heat Sink:

Well Water

Oxygen Removal Unit:

Type: Deoxo Gas Purifier

Pressure Drop:

Temperature Rise:

1.5 psi (approx.)

Gas Purity:

$\mathrm{O}_{2}$ Concentration

$\mathrm{H}_{2}$ Concentration

Water Vapor Removal Unit:

$1 \mathrm{~F}$

$1 \mathrm{ppm}$

$1000 \mathrm{ppm}$

Type: Molecular Sieve Absorbant

Number of absorbing units 2

Wt. of absorbant/unit

$350 \mathrm{lbs}$.

Argon inlet $\mathrm{H}_{2} \mathrm{O}$ content $\quad 40-50 \mathrm{ppm}$

Argon outlet Dew Point $-100 \mathrm{~F}$

Pressure Drop/unit 0.6 psi (approx.)

On Stream Time/unit

Regeneration Time/unit

$7-8$ days

Regeneration Gas

4-8 hours

Argon

$4 \quad$ Cooling System

Cooler

Type: Direct Cycle - Argon Bypass

Size:

$0-10 \mathrm{Kw}$

Argon Circulation Rate

$0-1100 \mathrm{cfm}$

Argon Inlet Temperature

80 to $105 \mathrm{~F}$

Argon Outlet Temperature

$70 \mathrm{~F}$

Pressure Drop

Heat Sink

$0.2^{\prime \prime} \mathrm{H}_{2} \mathrm{O}$

Freon 12

Refrigeration Unit

Type:

Refrigerant

Size

Temperature Control

$5 \quad$ Filtration System

Argon Flow Rate

Argon Temperature

Filter:

Type:

Size:

Pressure Drop:

Efficiency:
Direct Expansion System

Freon 12

5 Tons

$\pm 1 \mathrm{~F}$
$100 \mathrm{cfm}$

$70 \mathrm{~F}$

"Absolute"

24 " $\times 24$ " $\times 6$ "

$0.5^{\prime \prime} \mathrm{H}_{2} \mathrm{O}$

$99.97 \%$ (DOP Test) 
Iodine Removal System

Type

"Dorex" Type H42

Activated Charcoal

Canister Assembly

No. of Assemblies 3 (in series)

Size (per Assembly) $19^{\prime \prime} \times 19^{\prime \prime} \times 15^{\prime \prime}$

Total Pressure Drop

$0.45^{\prime \prime} \mathrm{H}_{2} \mathrm{O}$

6

Vacuum System

Vacuum Pump

Type

Mechanical

Free Air Displacement $65 \mathrm{cfm}$

Motor Size

$3 \mathrm{HP}$ 


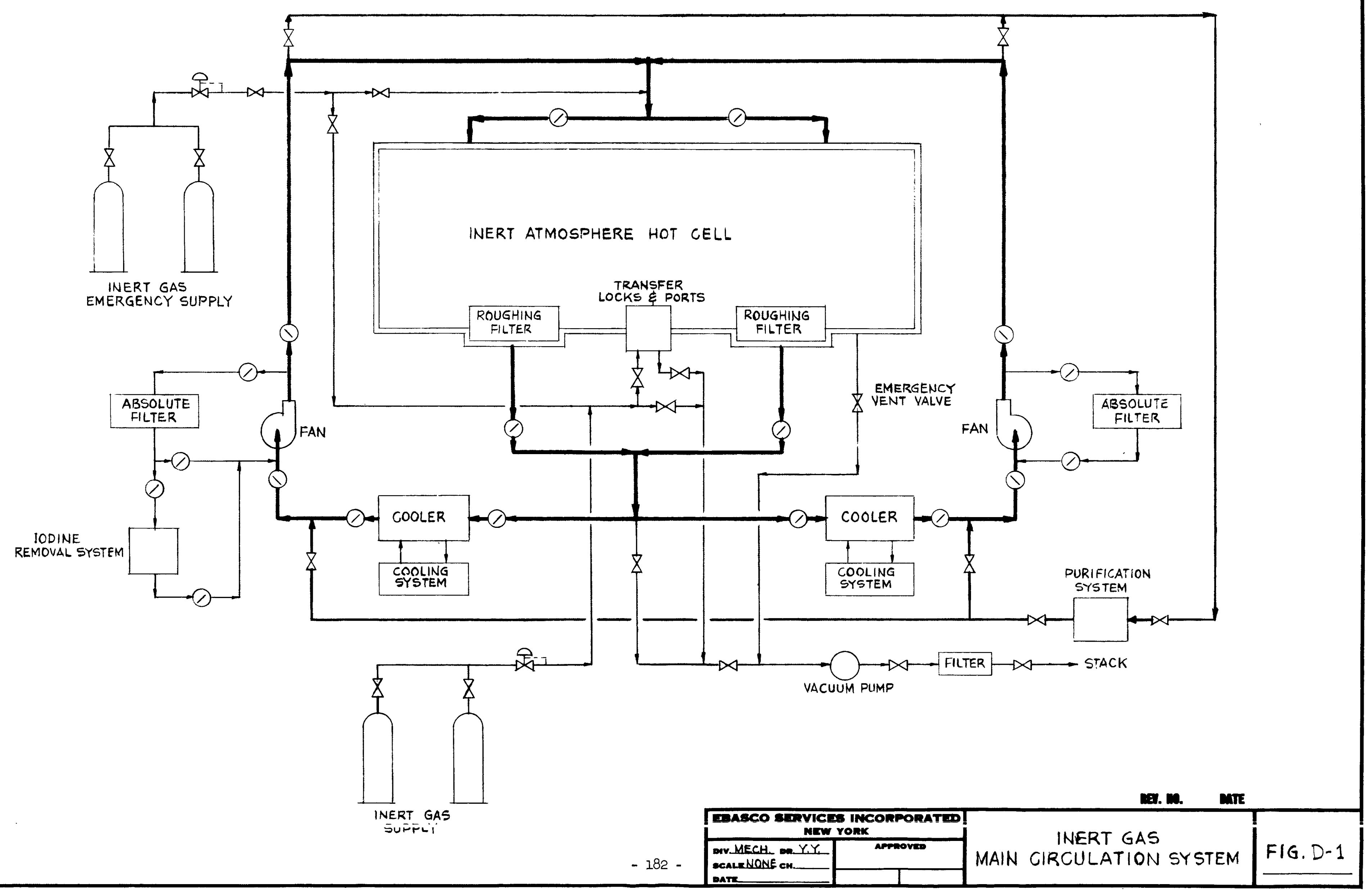


DESIGN DATA SHEET

M-1006

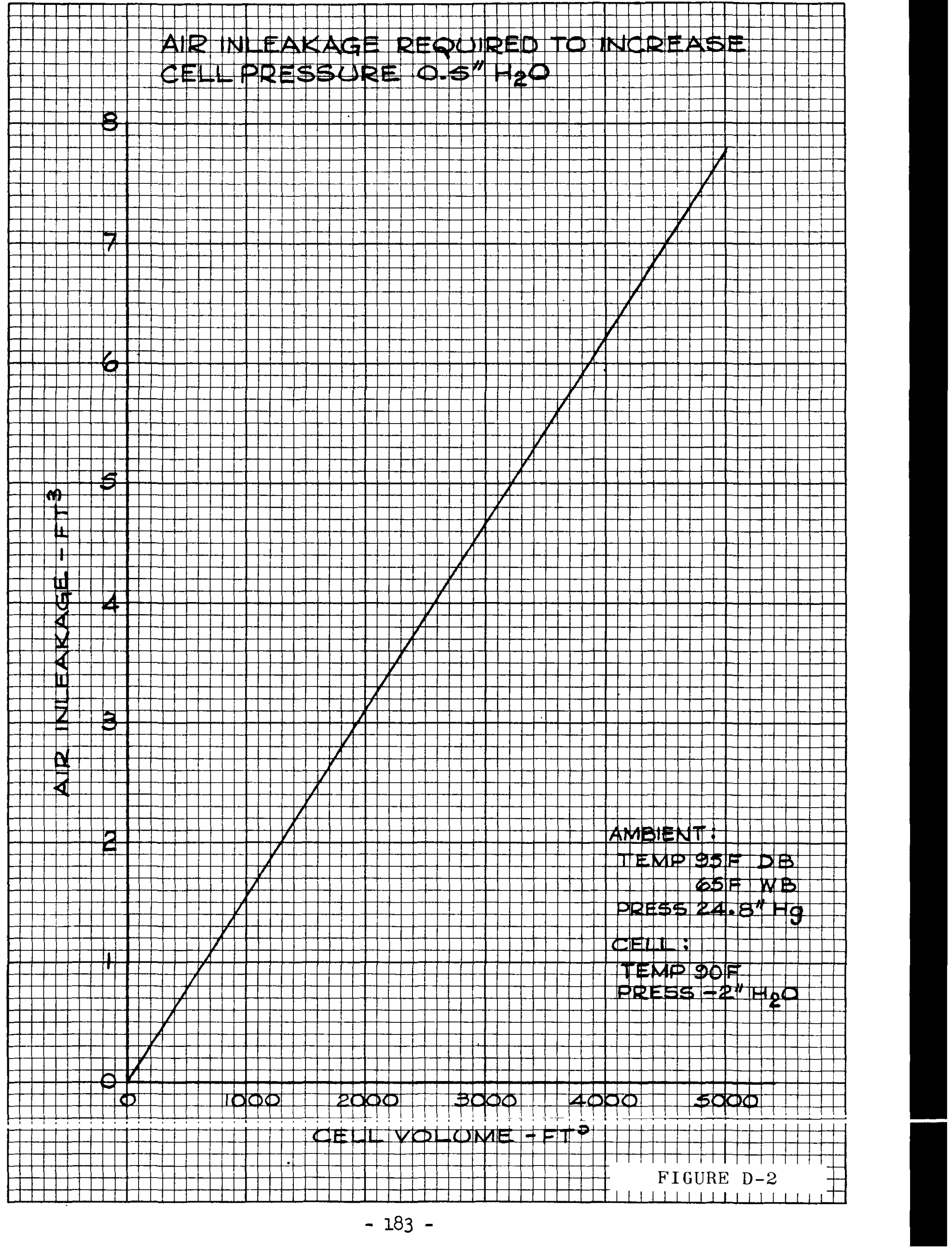




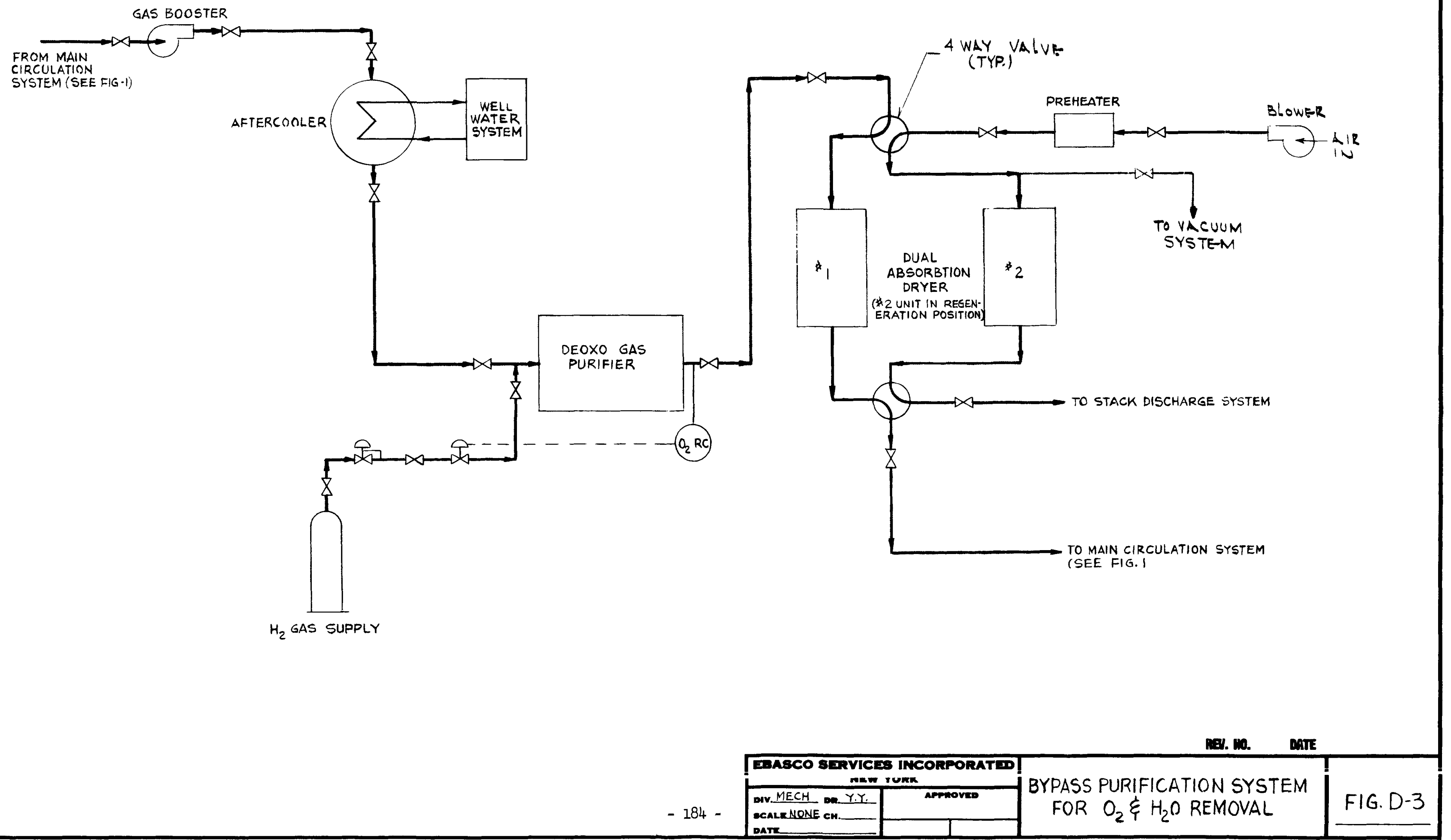




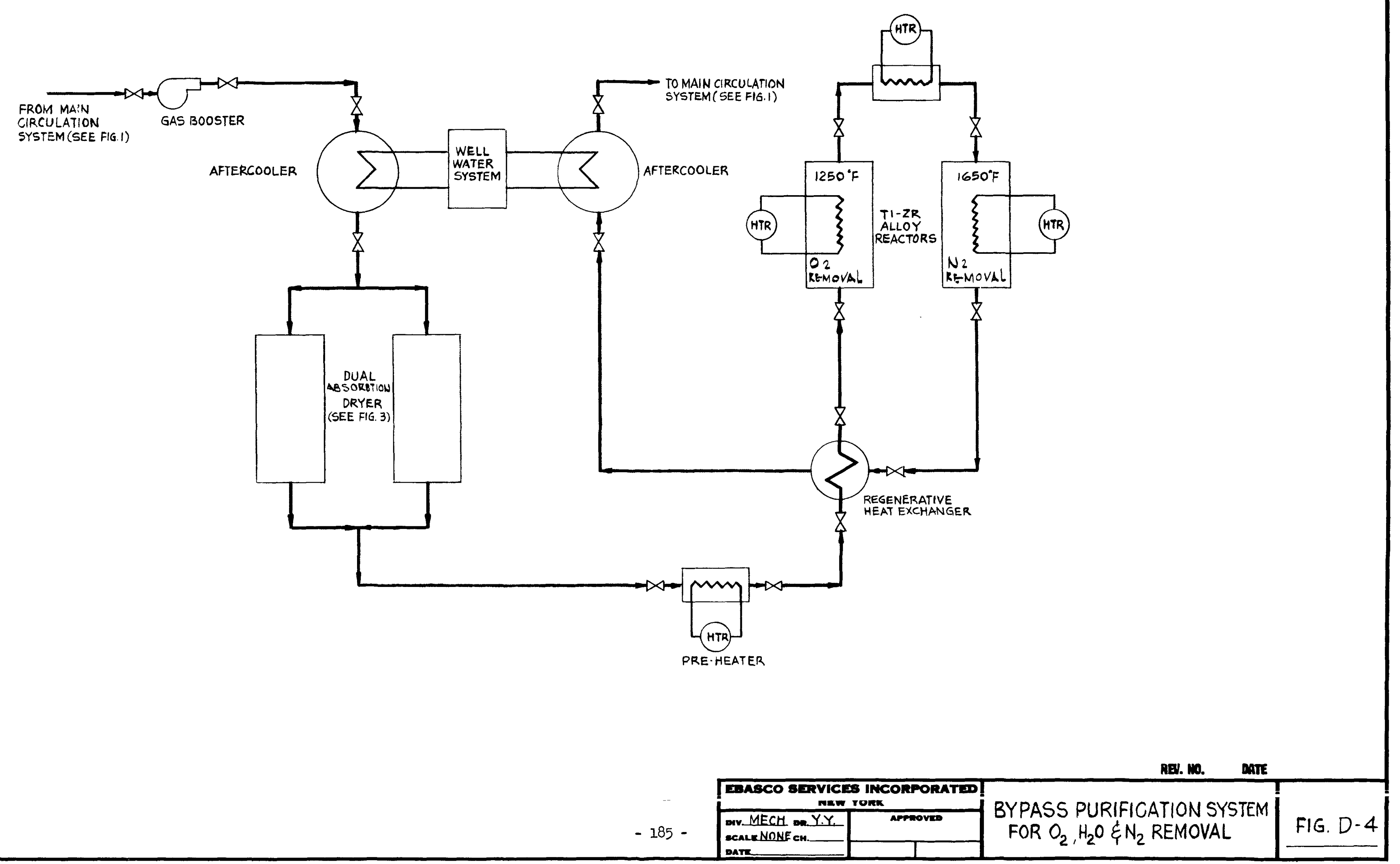




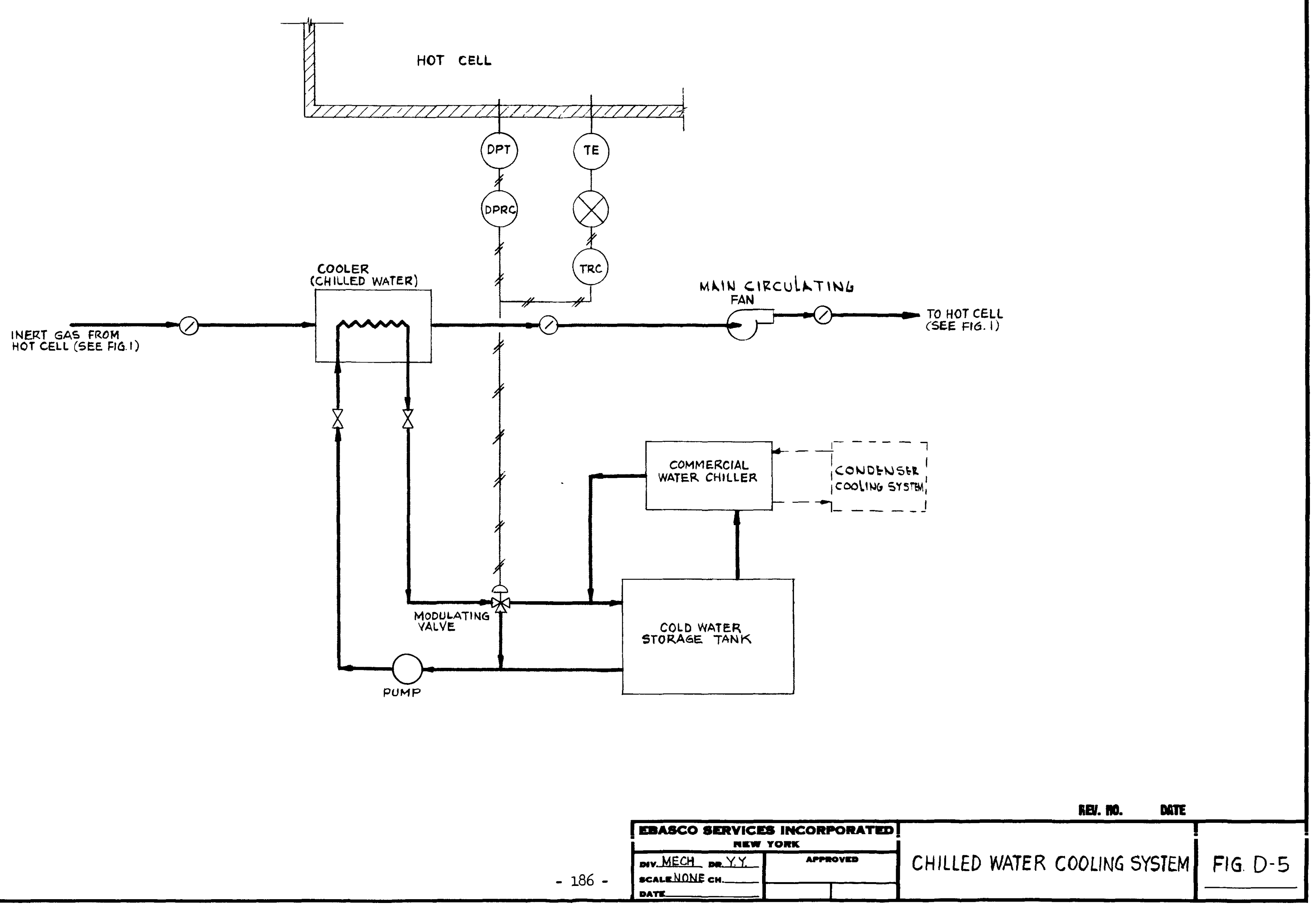




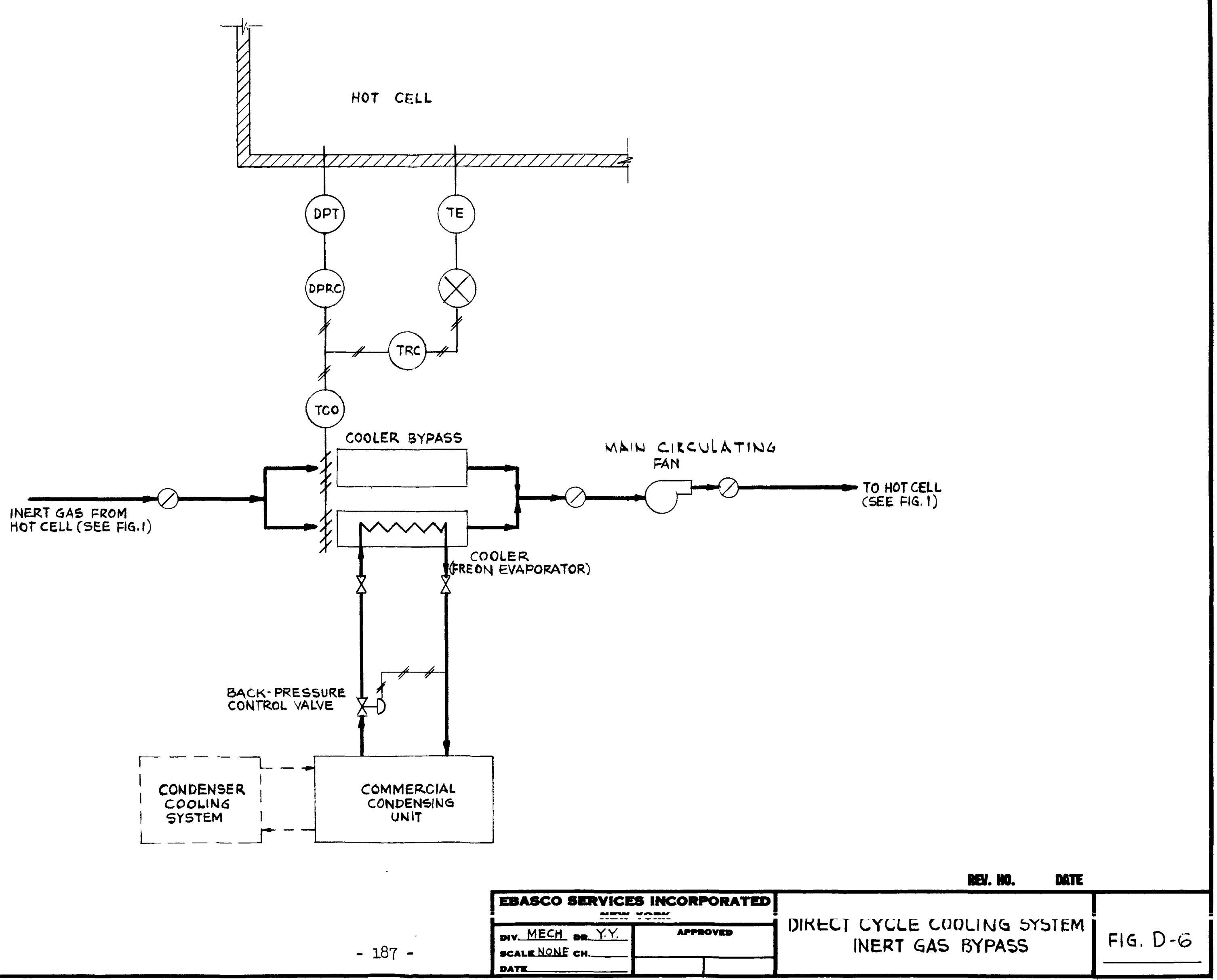




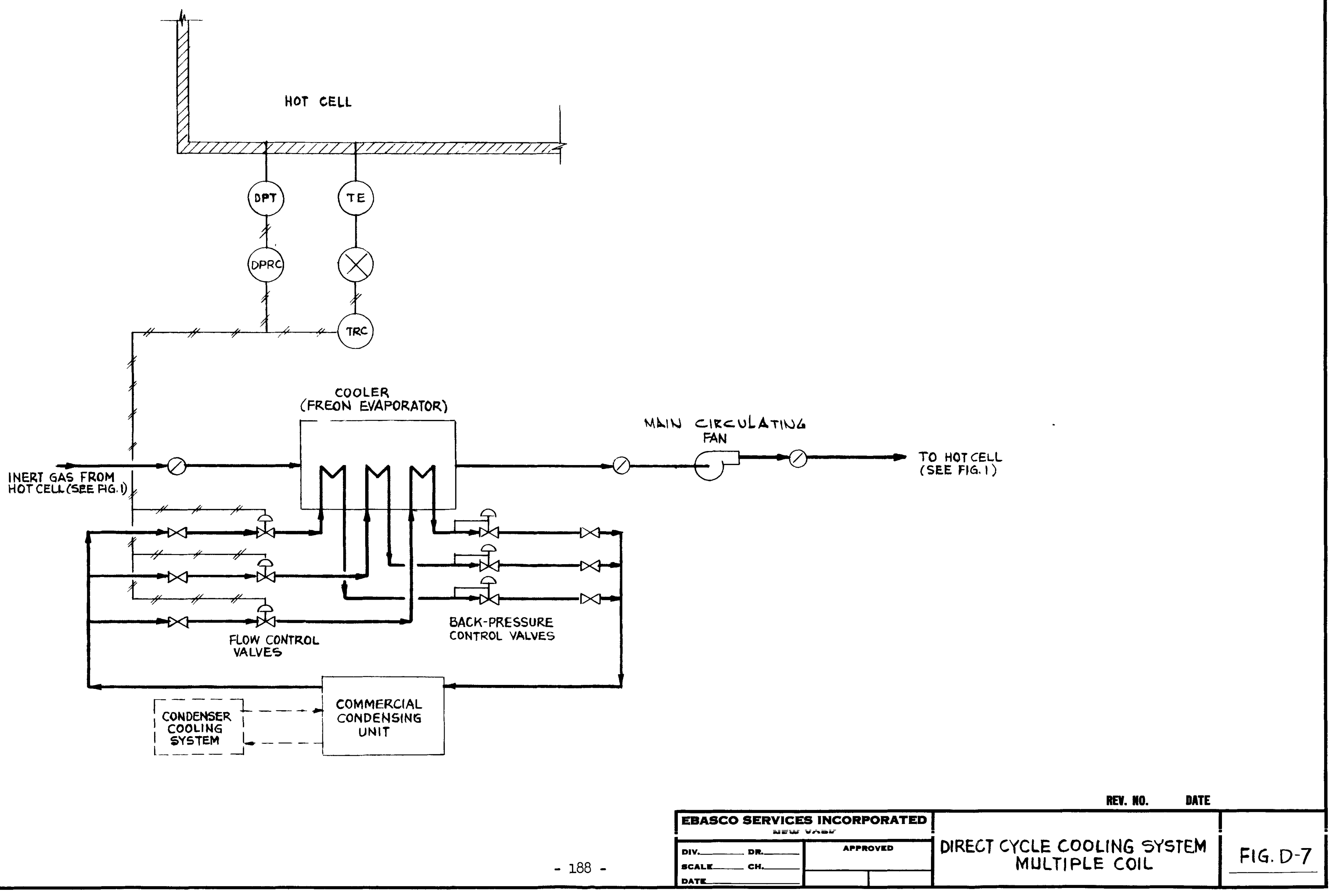




\section{APPENDIX E}

Fast Flux Liquid Metal Package Loop Decay Periods for Loop Handling 
O

0 
Design Data Sheet No. R-6007 59-3075-70

Contract No. AT(10-1)-1075

September 12, 1962

R. V. Straub/D. F. Judd

\author{
THE BABCOCK AND WILCOX COMPANY \\ FOR EBASCO SERVICES INCORPORATED \\ DESIGN DATA \\ ADVANCED TEST REACTOR \\ FAST FLUX LIQUID METAL PACKAGE LOOP \\ DECAY PERIODS FOR LOOP HANDLING
}

\title{
Purpose and Scope
}

The purpose of this Design Data Sheet is to present environmental conditions that are compatible with the design objective of $1000^{\circ} \mathrm{F}$ maximum specimen surface temperature after 10,000 hours of specimen irradiation, and to specify the decay time necessary before the NaK pump and secondary coolant helium flow can be shut off.

\section{General Description}

The loop and specimen used for the analyses are shown in IDO 24041, Design Criteria For a Fast Flux Liquid Metal Loop In The Advanced Test Reactor, Figures 3.2 and 4.1 .

The analyses are for the loop being handled from the time the reactor is shut down until the specimen is removed from the loop and during the reinsertion of an irradiated specimen in a loop. Since this analysis is to aid in establishing handling procedures, some conditions may not apply directly; however, they can be used as a guide.

The following conditions were assumed for the analyses:

1. The maximum surface temperature of the fuel clad is $1000^{\circ} \mathrm{F}$.

2. The characteristic decay curve for 10,000 hours irradiation shown in Appendix A was used.

3. When the loop is in-core the gamma heating rates shown in Appendix B were used.

4. When the loop is out of the core, core gamma heating is neglected.

5. When the helium coolant flow is shut off, the heat loss from the heat exchanger is neglected. All of the heat dissipated is assumed to be dissipated through the test section walls.

6. Natural circulation of $\mathrm{NaK}$ was not considered, but will be

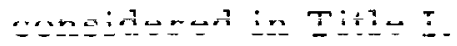


7. The loop stagnant helium annuli are filled with helium in all environments.

8. A $25 \%$ factor of safety was placed on the specimen fission power of $151 \mathrm{KW}$.

The following tabulation is a summary of the results of the analyses:

\section{Decay Time For Test Specimen}

\begin{tabular}{|c|c|c|c|c|}
\hline Case & & & Environment & Decay Time** \\
\hline & $\begin{array}{l}\text { NaK } \\
\text { Pump }\end{array}$ & $\begin{array}{l}\text { Helium } \\
\text { Flow }\end{array}$ & & \\
\hline I & On & Off & $\begin{array}{l}\text { Loop in-core, full flux trap } \\
\text { water flow }\end{array}$ & $1 / 2$ hour \\
\hline I I & Off & Off & $\begin{array}{l}\text { Loop in-core, full flux trap } \\
\text { water flow }\end{array}$ & 5 weeks \\
\hline I I I & On & Off & Loop in stagnant $100^{\circ} \mathrm{F}$ water $*$ & $1 / 4$ hour \\
\hline I V & Off & Off & Loop in stagnant $100^{\circ} \mathrm{F}$ water $*$ & 4 days \\
\hline $\mathrm{V}$ & Off & Off & $\begin{array}{l}\text { Loop in stagnant } 78^{\circ} \mathrm{F} \text { air or } \\
100^{\circ} \mathrm{F} \text { helium }\end{array}$ & $2-1 / 2$ weeks \\
\hline V I & Off & Off & $\begin{array}{l}\text { Specimen in stagnant helium } \\
\text { in loop, loop pressure tube } \\
\text { removed, loop cooled with } \\
100^{\circ} \mathrm{F} \text { flowing helium. }\end{array}$ & 4 weeks \\
\hline
\end{tabular}

Discussion

The decay time for each assumed environment was found by comparing the heat dissipated through the test section to the sum of the heat gained from the NaK pump, gamma heating from the ATR core, gamma heating from the extended core and the specimen decay heat. The decay time corresponds to the time the two values are the same.

The specimen decay heat and gamma heating from the ATR core and extended core are decreasing with time. Therefore, if the decay time is greater than the time shown in the tabulation, the specimen temperature will be less than $1000^{\circ} \mathrm{F}$ for the particular environment.

\section{Case I and Case I I}

Case I and Case I I consider the conditions when the loop is incore with the reactor shut down. No attempt has been made to

* Loop is removed from in-core position.

** Total elapsed time before environment is tolerable.

- $192-\quad E-2$ 
calculate the helium flow requirements during the $1 / 2$ hour decay period required. It has been estimated that approximately $10 \%$ of full load helium flow will be sufficient for the first few minutes of this period, and the flow then can be decreased to zero at $1 / 2$ hour.

As indicated by Case II, the NaK pump must be operated, with the loop in-core, at least 5 weeks before the specimen can be adequately cooled without NaK circulation. Since the analytical model used has neglected any natural circulation the decay period of 5 weeks is conservative.

2. Case II I and Case I V

These two cases consider the conditions when the loop is being handled between the reactor and the hot cell. It can be deduced from Case I V that the NaK pump must be operated at least 4 days after the reactor is shut down.

If the loop is to be handled through the transfer tube without utility connections, the loop must be held in-pile but out of core at least 4 days.

\section{Case V}

This Case corresponds to the environment the loop will be in when it is brought into the first hot cell to be dried. The loop must be allowed to decay at least 2-1/2 weeks before it can be safely brought into the air atmosphere.

The analysis for this Case considered natural convection cooling in the hot cell. The decay time could be shortened by operating the NaK pump until the outer pressure tube is removed and then using forced cooling as will be described for Case VI.

\section{Case V I}

If an irradiated specimen is being removed from or reinserted into the loop and is not submerged in $\mathrm{NaK}$, excessive decay time would be required unless forced cooling could be employed.

Case VI was analyzed assuming forced cooling could be used as shown schematically in Figure E-3. This scheme requires the outer pressure tube to be removed before the NaK is drained, and the specimen must be covered with NaK before the outer pressure tube is installed.

The amount of helium forced through the cooling jacket is $100 \mathrm{scfm}$. This helium would be supplied at about 1 -inch water pressure at tne jacker inıer. 


\section{Results and Conclusions}

The analyses, in many cases, were based on assumed conditions to aid in establishing reasonable handling procedures. After more definite handling procedures are established, more realistic calculations can be made.

Since consideration is being given to using argon in the inert atmosphere hot cell, an approximation has been made to determine the gross effect the argon atmosphere will have on the decay time required before an ir radiated specimen can be reinserted in the loop. It was estimated that the decay time for Case VI increased from 4 weeks to 6 months.

The detail design of the specimen and flow shroud will affect the heat loss and will be reflected in changes of decay time.

When the NaK pump operation is considered from the specimen cooling viewpoint alone, it is permissible to shut off the pump as indicated in the tabulation. It may not be advisable to ever shut off the pump when the effects are fully evaluated.

One effect that must be considered is the possibility of cold trapping. After a specimen has been irradiated, the decay heat from the specimen will induce natural circulation at very low circulation rates. The NaK may cool down enough to cause cold trapping which may result in some flow passages becoming plugged.

Another effect of the supposed low circulation rate is the induced large temperature difference in the NaK. This large temperature difference could cause excessive thermal shock and thermal stresses when the NaK pump is started. This would be a cyclic phenomenon until the system reached an equilibrium temperature. It is conceivable that the temperature difference existing in the $\mathrm{NaK}$ would exceed the design value of $300^{\circ} \mathrm{F}$ which could alter the pump clearances enough to cause binding in the impeller or bearings and actually result in pump failure.

If the handling procedures indicate that the loop will be handled with an irradiated specimen without the NaK pump operating, a Title I study will be made to evaluate the implications of these conditions and establish the design requirements that must be incorporated in the loop to accommodate them. 


\section{APPENDIX A ATR FAST LOOP SPECIMEN HEAT FLUX AFTER IRRADIATION}

At anytime after normal in-pile loop operation, the heating of the individual fuel pins caused by decay heat from fission products must be limited to prevent post-irradiation changes in the metallurgical properties of the fuel. Heat is produced in natural uranium after reactor shutdown by the following methods: (1) fission from delayed neutrons, (2) decay of radioactive fission products, and (3) decay of U-239 and $\mathrm{Np}-239$. Since the first item becomes insignificant within a few minutes after shutdown, the last two items are the only ones considered. A typical fission product decay curve for natural uranium was used as the basis for calculating the maximum specimen heat flux during the fission product decay period after irradiation. Figure E-4 is a curve of total decay power versus cooling time and is based on results from Untermyer and Weills. 1/ This curve includes the effect of U-239 and Np-239 but does not include the effect of the plutonium enrichment in the fuel specimen. The effect of the plutonium enrichment will be studied in detail in Title I. The values shown on the attached curve are judged sufficiently accurate for this analysis.

1/ Untermyer and Weills, Table 33. "Decay Heat Rate of Fission Products," H. Etherington, Ed., Nuclear Engineering Handbook, p. 1-39, McGrawHiii book Co., ınc., 1уวठ. 


\section{APPENDIX B}

\section{ATR FAST LOOP AFTER-SHUTDOWN GAMMA HEATING RATES}

At any time after normal in-pile loop operation, the heating of the test specimen and loop materials caused by decay heat from fission products in the ATR core and loop extended core fuel must be limited to prevent post-irradiation changes in the metallurgical properties of the specimen. Fission products in the ATR core and in the fast flux loop extended core are the only decay heat sources considered. The loop specimen power decay is covered in Appendix A.

The heat generated in the walls of the package loop by absorption of fission product gamma rays were calculated with a Babcock \& Wilcox Datatron-204 computer code that performs numerical integrations of point sources within a cylindrical source for each of five (5) energy groups. Integrated gamma-ray spectra from U-235 fission products 1/ were used for the computer sources. Irradiation times equal to the fuel cycles of 17 days for the ATR core fuel and 34 days for the loop extended core fuel were assumed for the fission product sources. A uniform axial source distribution was assumed in order to calculate the average heat generation rates and total heating in the in-core portion of the loop. A cosine distribution of $1.4 \mathrm{max} / \mathrm{avg}$ at core midplane and $0.4 \mathrm{~min} / \mathrm{avg}$ at core ends was then applied to the average heat generation rates in order to obtain specific heat generation rates in components. This calculational method had previously been checked by a more realistic and time consuming calculation in which the cosine distribution was applied to the gamma ray source strengths in the core material surrounding the loop rather than to the heating rates resulting from the calculation. The results of the two calculations were essentially the same.

The loop configuration used for the heat generation calculations is shown in Figure 3.3 of IDO-2404l "Design Criteria For A Fast Flux Liquid Metal Loop In The Advanced Test Reactor."

Table I lists the total gamma heating in the loop materials at one (1) hour after reactor shutdown and Figure E-l shows the total gamma heating versus time after reactor shutdown. Figure E- 2 shows the average heat generation rates obtained for various materials in the loop versus time after reactor shutdown. In order to obtain specific heat generation rates at any specified location in the materials, the cosine distribution of $1.4 \mathrm{max} / \mathrm{avg}$ at core midplane and $0.4 \mathrm{~min} / \mathrm{avg}$ at core top may be applied to the values shown on Figure E-2. All of the results are based on a $40 \mathrm{MW}$ lobe power and 3.50 $\mathrm{MW}$ extended core power.

1/ H. Goldstein, Fundamental Aspects of Reactor Shielding, AddisonWesley Publishing Co., Inc., 1959. 
TABLE I

TOTAL GAMMA RAY HEAT GENERATION IN FAST FLUX LOOP AT ONE (1) HOUR AFTER REACTOR SHUTDOWN

Lobe Power - $40 \mathrm{MW}$

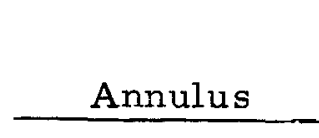

Fuel

$\mathrm{NaK}-44$

Stainless Steel

Stainless Steel

Helium

Stainless Steel

$\mathrm{NaK}-44$

Stainless Steel

Stainless Steel

Boron Stainless

Steel

Sub-Total for in-core Portion

Portion of loop above core

Total Gamma Ray Heat Load
Total Heating in

Loop Components (KW)

\subsection{8}

0.210

2.151

2.256

2.318

0.228

2.373

2.548

2.688

0.69

0.07

0.23

0.69

$-$

0.66

0.10

0.83

2.00

1.31

6.58

0.66

$7.24 \mathrm{KW}$ 


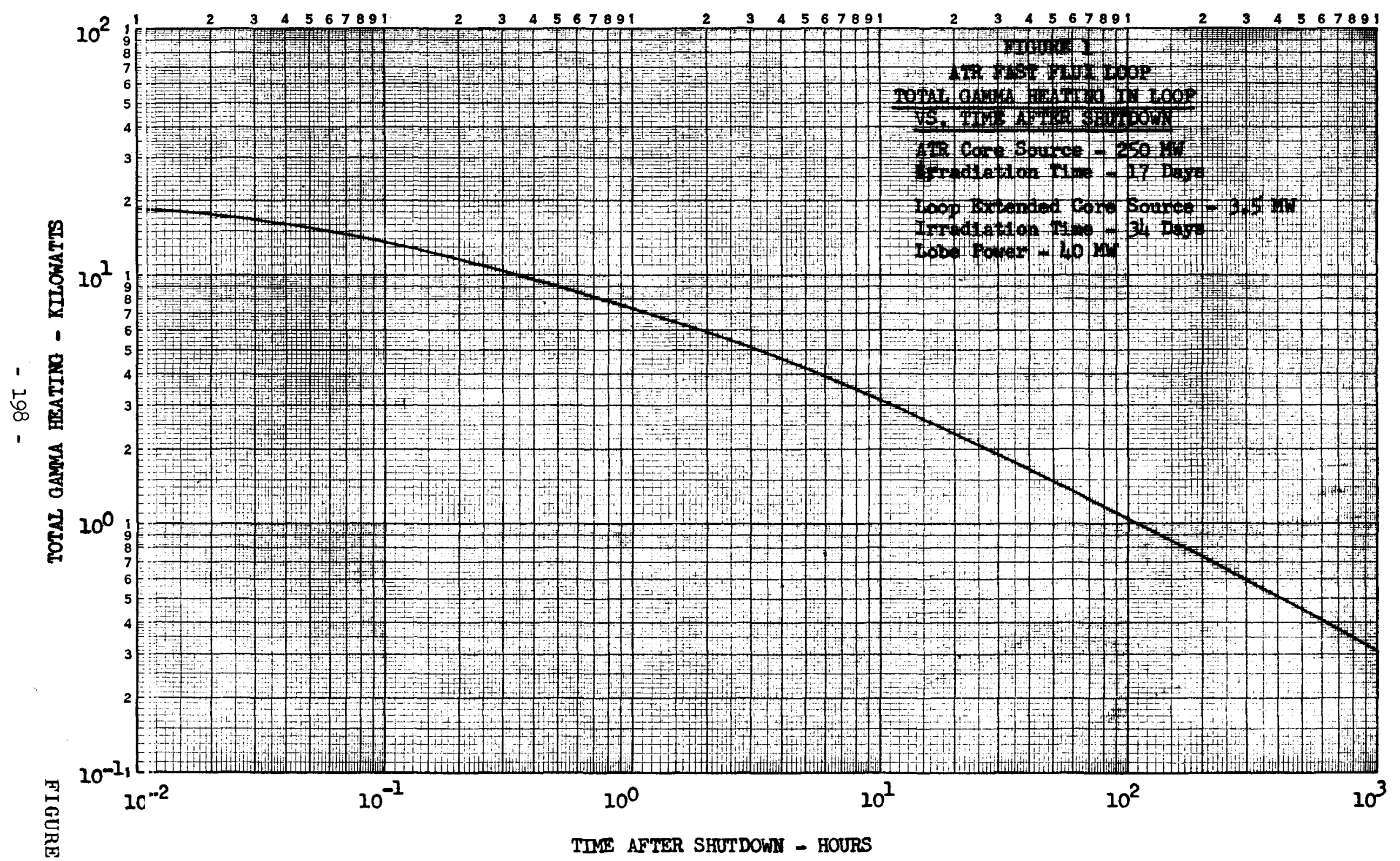




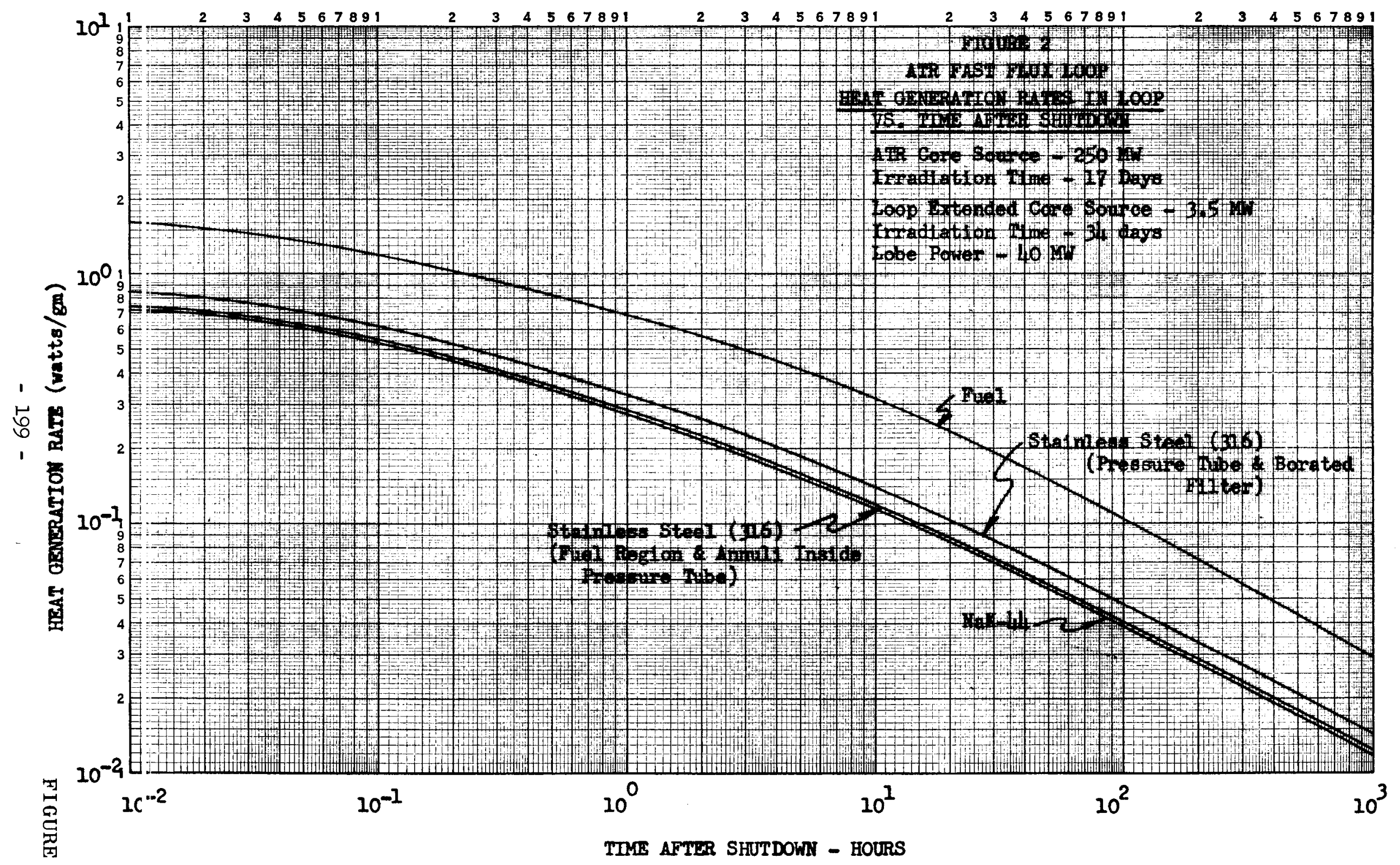




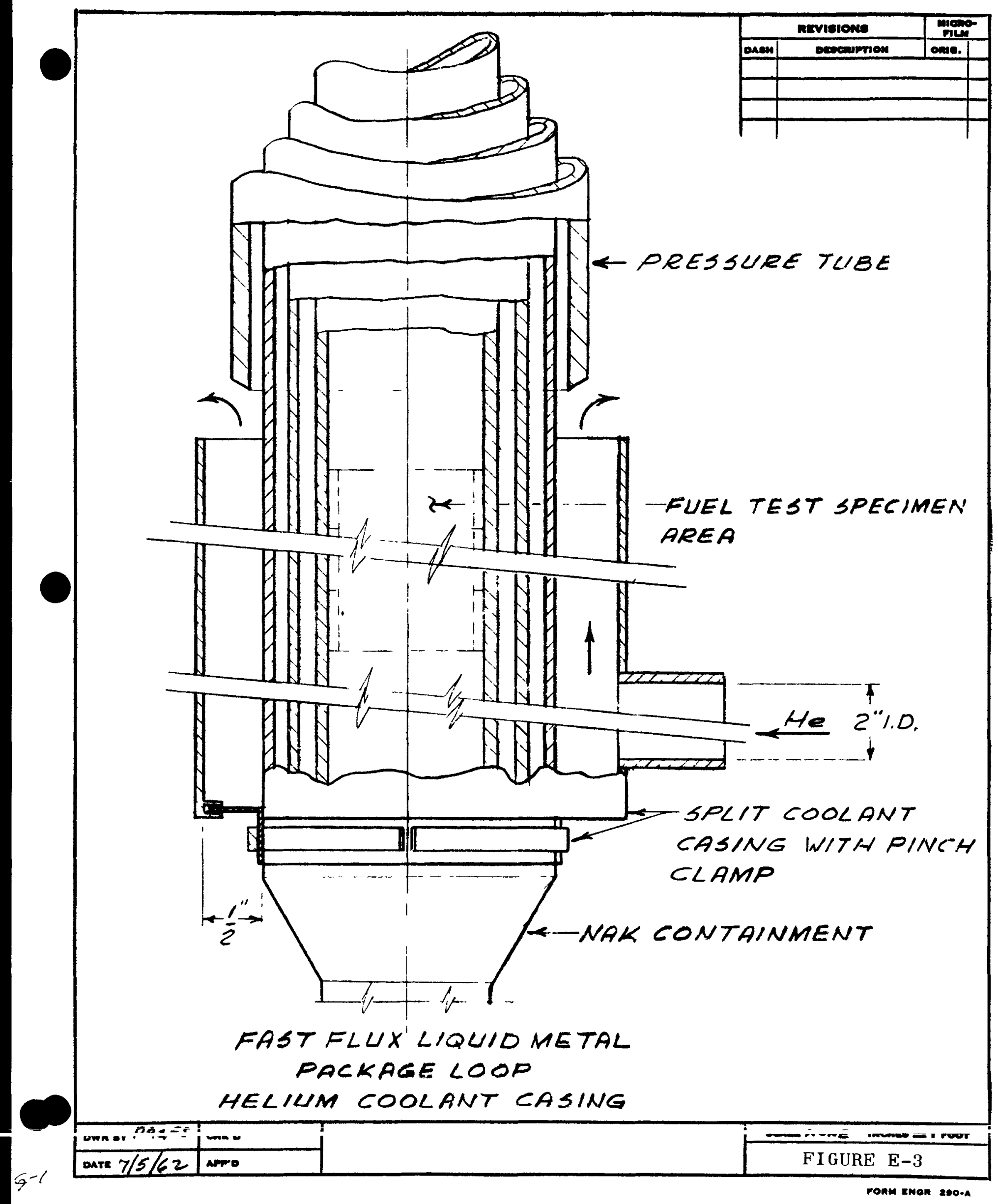




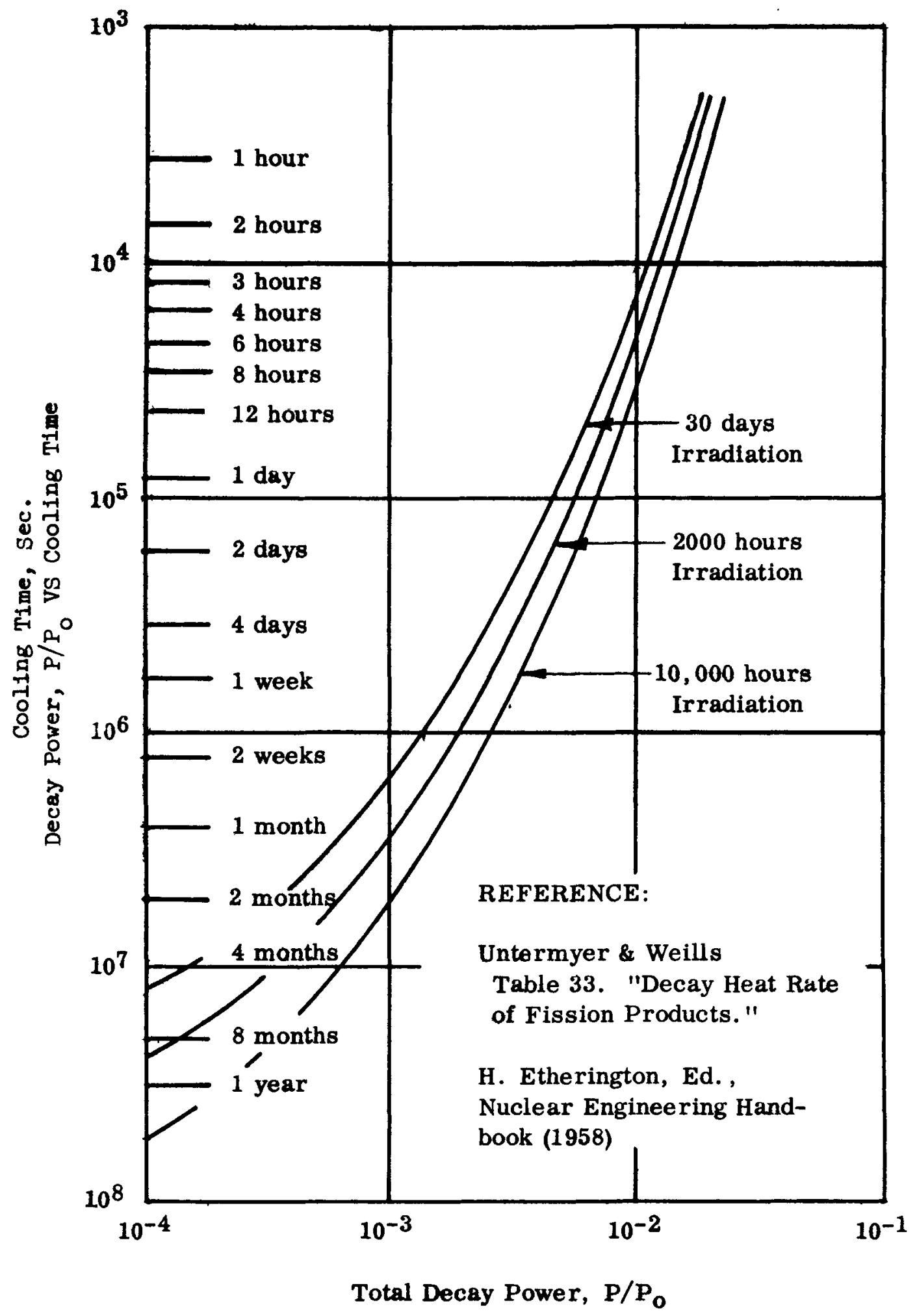

FIGURE E-4 
-

-

8 


\section{APPENDIX F}

Thermal Flux Liquid Metal Package Loop

Decay Periods for Loop Handling 
0 
Design Data Sheet R-6011 59-3075-70

Contract No. AT(10-1)-1075

August 27, 1962

R. V. Straub/D. F. Judd

\author{
THE BABCOCK \& WILCOX COMPANY \\ FOR EBASCO SERVICES INCORPORATED \\ DESIGN DATA \\ ADVANCED TEST REACTOR \\ THERMAL FLUX LIQUID METAL PACKAGE LOOP \\ DECAY PERIODS FOR LOOP HANDLING
}

\title{
Purpose and Scope
}

The purpose of this Design Data Sheet is to present environmental conditions that are compatible with the design objective of $1000^{\circ} \mathrm{F}$ maximum specimen surface temperature after 10,000 hours of specimen irradiation, and to specify the decay time necessary before the sodium pump and secondary coolant helium flow can be shut off.

\section{General Description}

The loop and specimen configuration used for this analysis are shown on the following drawings.

\section{Thermal Flux Liquid Metal Package Loop In-Core Section - SKC-2933E \\ Thermal Flux Liquid Metal Package Loop Fuel Test Specimen - SKC-2972E}

The analyses are for the loop being handled from the time the reactor is shut down until the specimen is removed from the loop and during the reinsertion of an irradiated specimen in a loop. Since this analysis is to aid in establishing handling procedures some conditions will not apply directly; however, they can be used as a guide.

The following conditions were assumed for the analyses.

1. The maximum surface temperature of the fuel clad is $1000^{\circ} \mathrm{F}$.

2. The characteristic decay curve for 10,000 hours irradiation shown in Appendix A was used.

3. When the loop is in-core the gamma heating rates shown in Appendix B were used.

4. When the loop is out of the core, gamma heating is neglected.

5. When the helium coolant is shut off, the heat loss from the heat exchanger is neglected; all of the heat dissipated is as sumed to be dissipated through the test section walls.

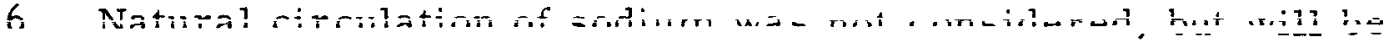
considered in Title I. 
7. The loop annuli are filled with helium in all environments.

8. A $25 \%$ factor of safety was placed on the specimen fission power of $1500 \mathrm{KW}$.

9. The contact pressure at the tips of the flutes is between $400 \mathrm{psi}$ and $800 \mathrm{psi}$. The surface finish at the contact surface is 30 micro-inches. If this pressure cannot be attained, the contact resistance will be increased thus requiring a longer decay time before handling. The effects of a lower contact pressure will be studied in detail in Title I.

10. To avoid freezing a minimum sodium temperature of $250^{\circ} \mathrm{F}$ was used.

The following tabulation is a summary of the results of the analyses:

Decay Time For Test Specimen

\begin{tabular}{|c|c|c|c|c|c|}
\hline \multirow[t]{2}{*}{ Case } & \multicolumn{4}{|c|}{ Environment } & \multirow[t]{2}{*}{ Decay Time* } \\
\hline & $\begin{array}{l}\text { Sodium } \\
\text { Pump } * * \\
\text { Power, } \mathrm{KW}\end{array}$ & $\begin{array}{l}\text { Sodium } \\
\text { Temp. }{ }^{\circ} \mathrm{F}\end{array}$ & $\begin{array}{l}\text { Helium } \\
\text { Flow }\end{array}$ & & \\
\hline 1 & 12 & $\begin{array}{c}975 \\
(\max .)\end{array}$ & Off & $\begin{array}{l}\text { Loop In-Core, Full Reactor } \\
\text { Water Flow }\end{array}$ & $10 \mathrm{sec}$. \\
\hline I I & 12 & 250 & Off & $\begin{array}{l}\text { Loop In-Core, Full Reactor } \\
\text { Water Flow }\end{array}$ & 2 weeks $1 /$ \\
\hline I I I & 12.0 & $\begin{array}{c}975 \\
(\max .)\end{array}$ & Off & $\begin{array}{l}\text { Loop in Stagnant } 100^{\circ} \mathrm{F} \\
\text { Water }\end{array}$ & $10 \mathrm{sec}$. \\
\hline I V & 12.0 & 250 & Off & $\begin{array}{l}\text { Loop In Stagnant } 1000 \mathrm{~F} \\
\text { Water }\end{array}$ & 8 days $1 /$ \\
\hline $\mathrm{V} \underline{2}$ & 12.0 & $\begin{array}{l}250 \\
\text { min. }\end{array}$ & - & $\begin{array}{l}\text { Loop in Stagnant } 100^{\circ} \mathrm{F} \\
\text { Water, } 25 \mathrm{KW} \text { added to } \\
\text { sodium }\end{array}$ & - \\
\hline $\mathrm{VI} \underline{2}$ & 1.0 & $975 \max$. & C. Off & Loop in Stagnant $100^{\circ} \mathrm{F} \mathrm{Air}$ & 4 weeks \\
\hline V I I & 1.0 & $975 \max$. & c. Off & $\begin{array}{l}\text { Loop in Stagnant } 250^{\circ} \mathrm{F} \\
\text { Helium }\end{array}$ & 6 weeks \\
\hline V I I I & Off & - & Off & $\begin{array}{l}\text { Loop in Stagnant } 250^{\circ} \mathrm{F} \\
\text { Helium }\end{array}$ & $3-1 / 2$ weeks \\
\hline IX & Off & - & Off & $\begin{array}{l}\text { Specimen in Stagnant } \\
\text { Helium In Loop, Loop } \\
\text { Cooled with } 250^{\circ} \mathrm{F} \\
\text { Flowing Helium }\end{array}$ & 27 weeks \\
\hline
\end{tabular}

* Total Elapsed Time before environment is tolerable..

*** Energy added to flowing sodium by primary pump.

1/ Total Elapsed Time before sodium temperature is reached.

2) Loop can be held in this condition indefinitely without freezing. 


\section{Discussion}

The decay time for each assumed environment was found by comparing the heat dissipated through the test section with the sum of the heat gained from the sodium pump, gamma heating from the ATR core, and the specimen decay heat. The decay time corresponds to the time the two values are the same.

The specimen decay heat and gamma heating from the ATR core are decreasing with time. Therefore, if the decay time is greater than the time shown in the tabulation, the specimen temperature will be less than $1000^{\circ} \mathrm{F}$ for the particular environment.

1. Case I and Case I I

Case I and Case I I consider the conditions when the loop is in-core with the reactor shut down. No attempt has been made to calculate the helium flow requirements dur ing these decay periods.

2. Case III, Case I V and Case V

These cases consider the conditions when the loop is being handled between the reactor and the hot cell. Case IV indicates that auxiliary heat must be added after 8 days to prevent the sodium from freezing. This case also indicates that the loop can be handled through the transfer tube during the first 8 days without auxiliary heating being required.

3. Case VI

This case corresponds to the environment the loop will be in when it is brought into the first hot cell to be dried. The loop must be allowed to decay at least 4 weeks before it can be safely brought into the air atmosphere.

The analysis for this case considered natural convection cooling in the hot cell. The decay time could be shortened by using forced cooling as will be described for Case IX.

4. Case VII and Case VIII

These cases were analyzed and included based on the assumption that the hot cell atmosphere may be maintained at $250^{\circ} \mathrm{F}$ to prevent freezing of the sodium. If the hot cell cannot be maintained at this high a temperature, the temperature of the atmosphere immediately surrounding the loop should be. 


\section{Case I X}

If an irradiated specimen is being removed or reinserted in the loop and is not submerged in sodium, decay time would be required unless forced cooling could be employed.

Case IX was analyzed assuming forced cooling could be used as shown schematically in Figure F-3.

The amount of helium forced through the cooling jacket is $350 \mathrm{scfm}$. This helium would be supplied at about 1 -inch water pressure at the jacket inlet.

Results and Conclusions

The analyses, in many cases, were based on assumed conditions to aid in establishing reasonable handling procedures. After more definite handling procedures are established, more realistic calculations can be made.

Since consideration is being given to using argon in the inert atmosphere hot cell an estimation has been made to determine the gross effect it will have on the decay time required before the specimen can be re-inserted in the reactor. It has been estimated that the decay time for Case IX will increase from 27 weeks to 18 months.

The detail design of the specimen and flow shroud will affect the heat loss and will be reflected in changes of decay time.

When the sodium pump operation is considered from the specimen cooling view point alone, it is permissible to reduce pumping power and to shut off the pump as indicated in the tabulation. This procedure may not be advisable when the effects are fully evaluated.

One effect that must be considered is the possibility of cold trapping. After a specimen has been irradiated, the decay heat from the specimen will induce natural circulation at very low circulation rates. The sodium may cool down enough to cause cold trapping which may result in some flow passages becoming plugged. It is also conceivable that the sodium temperature could drop low enough that it would freeze in some isolated regions. Another effect of a low circulation rate is the induced large temperature difference in the sodium. This large temperature difference could cause excessive thermal shock and thermal stresses when the sodium pump is started. This would be a cyclic phenomenon until the system reached an equilibrium temperature. It is conceivable that the temperature difference existing in the sodium would exceed the design value of $350^{\circ} \mathrm{F}$.

If the handling procedures indicate that the loop will be handled with an irradiated specimen without the sodium pump operating, a Title I Study will be made to evaluate the implications of these conditions and establish the design requirements that must be incorporated in the loop to accommodate them. 


\section{APPENDIX A}

ATR THERMAL LOOP SPECIMEN HEAT FLUX AFTER IRRADIATION

At anytime after normal in-pile loop operation, the heating of the individual fuel elements caused by decay heat from fission products must be limited to prevent post-irradiation changes in the metallurgical properties of the fuel. Heat is produced in natural uranium after reactor shutdown by the following methods: (1) fissions from delayed neutrons, (2) decay of radioactive fission products, and (3) decay of U-239 and $\mathrm{Np}-239$. Since item (1) becomes insignificant within a few minutes after shutdown, the last two items are the only ones considered. A typical fission product decay curve for natural uranium was used as the basis for calculating the maximum specimen heat flux during the fission product decay period after irradiation. Figure F-4 is a curve of total decay power versus cooling time and is based on results from Untermyer and Weills. I/ This curve includes the effect of U-239 and Np-239. The decay power will be studied in detail in Title I.

1/ Untermyer and Weills, Table 33. "Decay Heat Rate of Fission Products," H. Etherington, Ed., Nuclear Engineering Handbook, p. 1-39, McGraw-Hill Book Co., Inc., 1958. 
Design Data Sheet R-6011

\author{
APPENDIX B \\ ATR THERMAL LOOP AFTER SHUTDOWN GAMMA HEATING RATES
}

At any time after normal in-pile loop operation, the heating of the test specimen and loop materials caused by decay heat from fission products in the ATR core fuel must be limited to prevent post-irradiation changes in the metallurgical properties of the specimen. Fission products in the ATR core are the only decay heat source considered. The loop specimen power decay is covered in Appendix A.

The heat generated in the walls of the package loop by absorption of fis sion product gamma rays was calculated with a Babcock \& Wilcox Datatron- 204 computer code that performs numerical integrations of point sources within a cylindrical source for each of five (5) energy groups. Integrated gamma ray spectra from U-235 fission products $1 /$ were used for the computer sources. An irradiation time equal to the ATR fuel cycle of 17 days was assumed for the fission product sources. A uniform axial source distribution was assumed in order to calculate the average heat generation rates and total heating in the in-core portion of the loop. A cosine distribution of $1.4 \mathrm{max} / \mathrm{avg}$ at core midplane and $0.4 \mathrm{~min} / \mathrm{avg}$ at core ends was then applied to the average heat generation rates in order to obtain specific heat generation rates in components. This calculational method had previously been checked by a more realistic and time consuming calculation in which, the cosine distribution was applied to the gamma ray source strength in the core material surrounding the loop, rather than to the heating rates resulting from the calculation. The results of the two calculations were essentially the same.

The loop configuration used for the heat generation calculations is shown in SKC-2933E.

Table I lists the total gamma heating in the loop materials at one (1) hour after reactor shutdown and Figure F-l shows the total gamma heating versus time after shutdown. Figure F-2 shows the average heat generation rates obtained for various materials in the loop versus time after reactor shutdown. In order to obtain specific heat generation rates at any specified location in the materials, the cosine distribution of $1.4 \mathrm{max} / \mathrm{avg}$ at core midplane and $0.4 \mathrm{~min} / \mathrm{avg}$ at core end may be applied to the values shown on Figure F-2. All of the results are based on the ATR core total power of $250 \mathrm{MW}$.

1) H. Goldstein, Fundamental Aspects of Reactor Shielding, AddisonWesley Publishing Co., Inc., 1959 


\section{TABLE I}

TOTAL GAMMA RAY HEAT GENERATION

IN ATR THERMAL FLUX LOOP

AT ONE (1) HOUR AFTER REACTOR SHUTDOWN

Reactor Power - $250 \mathrm{MW}$

Total Gamma

Heating in Loop

Loop Component

Fuel

Na Upflow

Test Specimen

Steel

(Baffles, Cladding)

Test Specimen

Containing Tube

$\mathrm{Na}$ Downcomer

Pressure Tube

Stainless Steel (316)

Subtotal for In-Core Portion

Bottom 6" of

Loop

Portion of Loop

Above Core ( 1.5 feet)

Stainless Steel (316)

Sodium

Steel and Sodium
Avg Heat Generation

Rate (watts/cc)

3.039

3.07

10.157

0.246

2.538

0.334

1.01

3.944

9.57

27.65

0.42

0.83

Total Gamma Ray Heat Load
$28.90 \mathrm{KW}$ 


\section{-}

8 


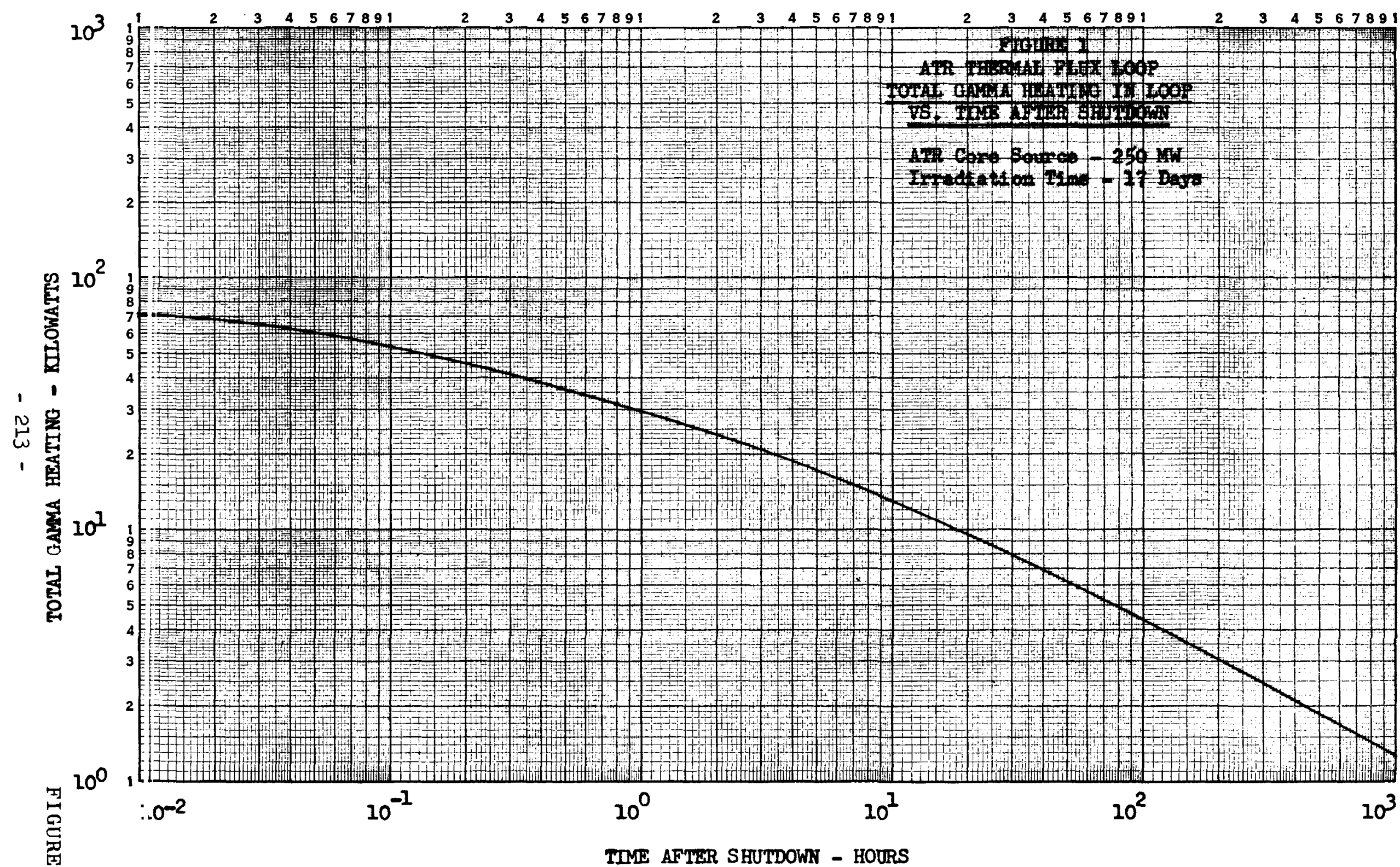


8 


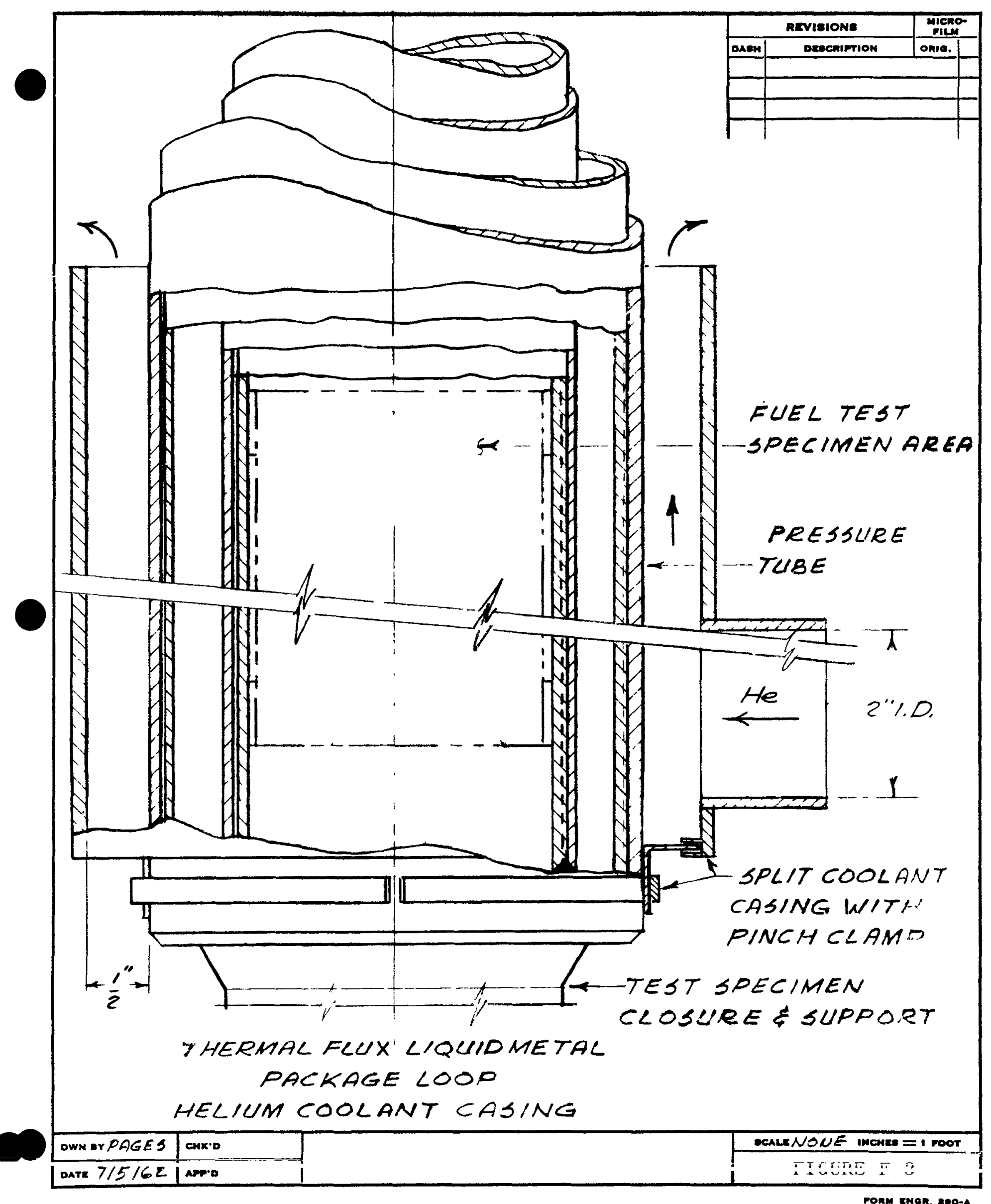

$G-2$ 


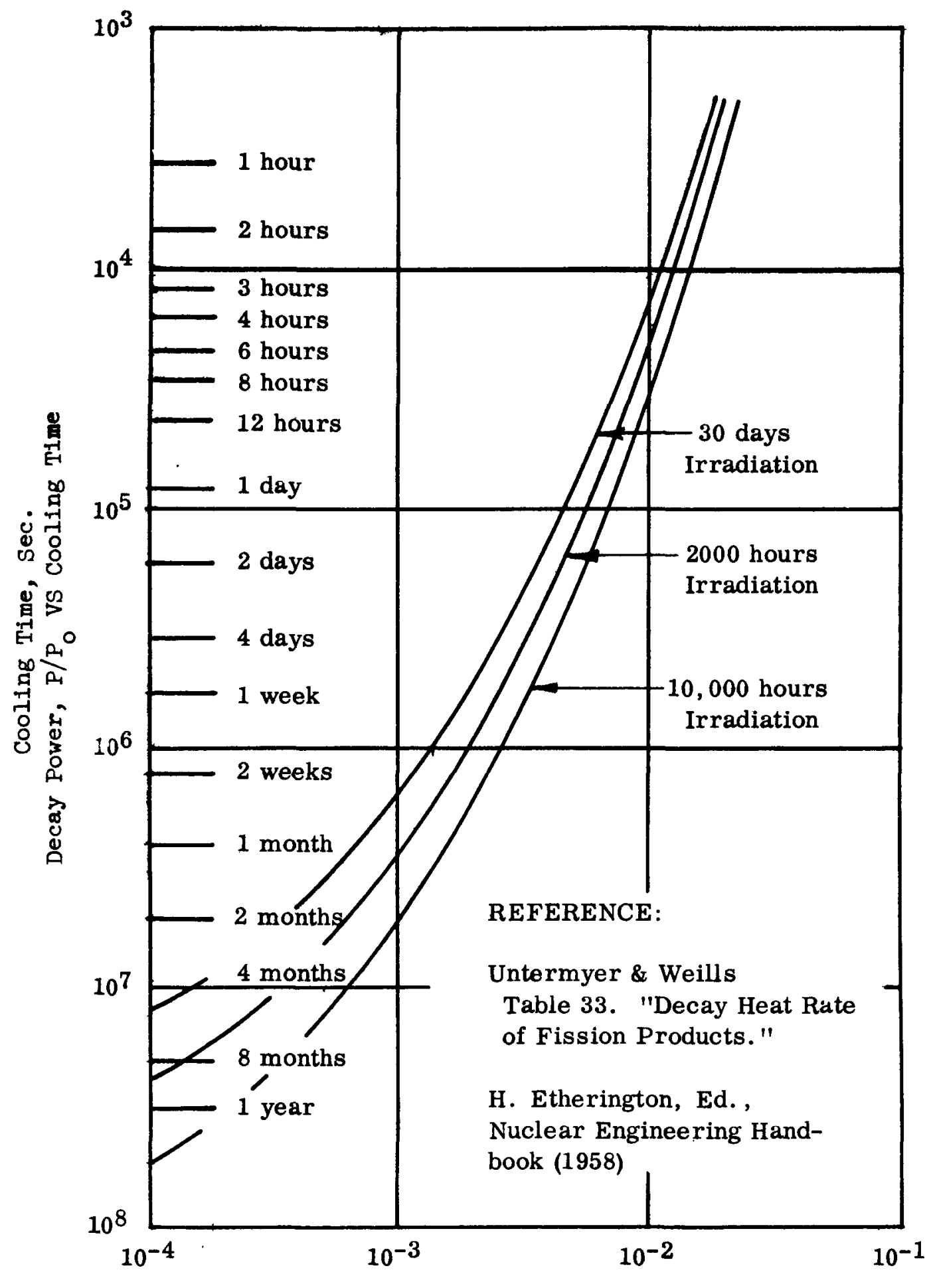

Total Decay Power, $\mathrm{P} / \mathrm{P}_{\mathrm{o}}$ 


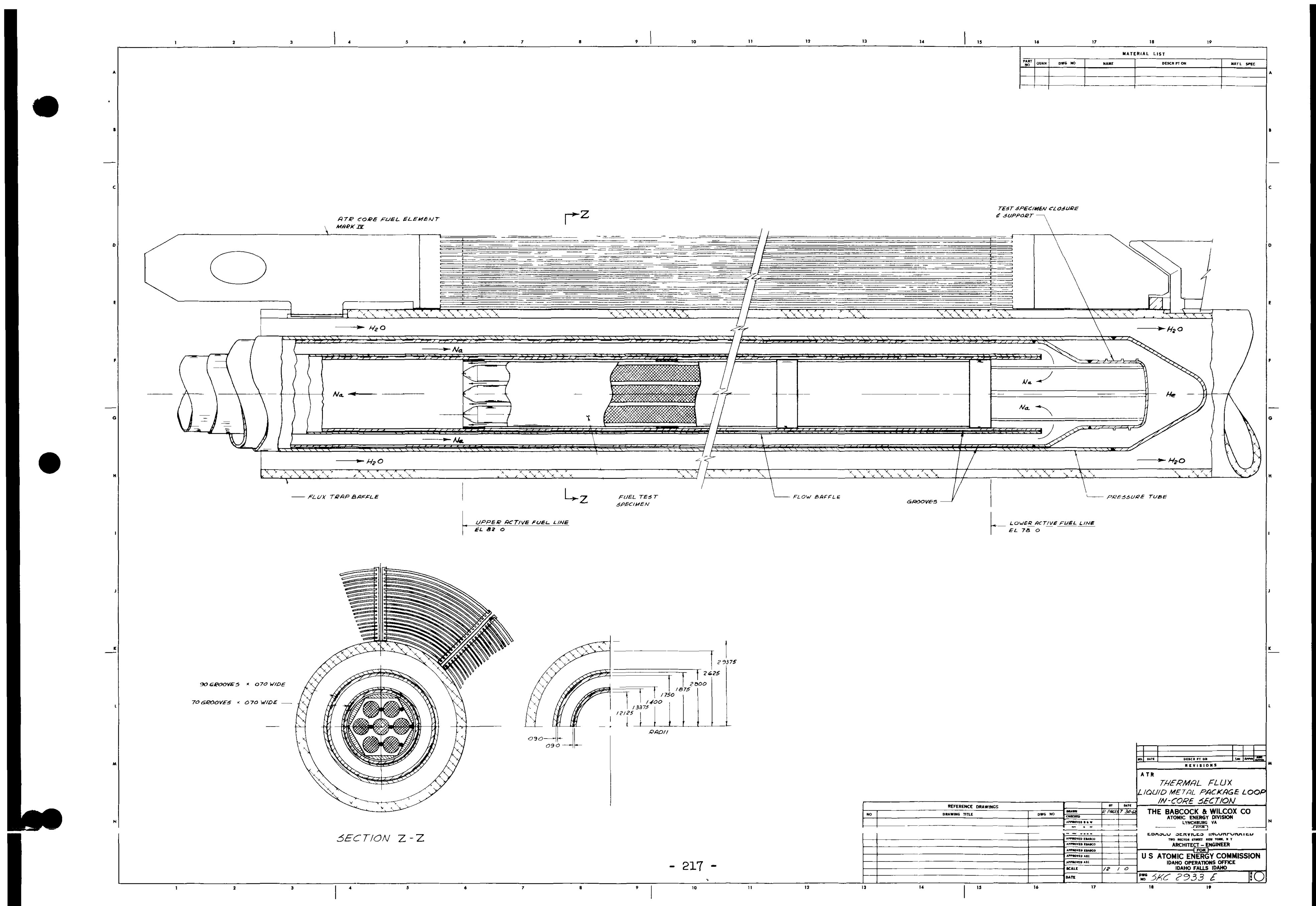




\section{APPENDIX G}

\section{Loop Handling Procedures}


0

o

0 


\section{APPENDIX G}

\section{REMOVAL AND RENEWAL OF BORON FILTER AND PRESSURE TUBE}

The following describes the operations to be performed and the equipment required in the hot cell in order to:

I. Replace the thermal neutron filter

II. Remove an irradiated specimen from the loop

II Reinsert an irradiated specimen into the loop

IV. Fill a loop with liquid metal and helium

V. Description of hot cell equipment and services required.

All operating and equipment requirements are based on the Fast Flux Loop but a re applicable, in general, to the Thermal Flux Loop also. The major differences between the loops exist in the following areas:

a. The thermal loop has no thermal neutron filter. Therefore, Item I above is not applicable to the thermal loop.

b. The thermal loop must be heated to $250-300^{\circ} \mathrm{F}$ when sodium is in the loop (the fast loop contains NaK which will not freeze at expected hot cell temperatures).

c. Certain parts of the thermal loop are larger than those of the fast loop, thus requiring tools and machinery sized appropriately.

\section{A. HANDLING OPERATIONS}

\section{Initial Conditions}

a. The loop, with handling extension installed, is suspended from the crame in the helium atmosphere hot cell.

b. The floor plug is installed in the opening above the transfer cask.

\section{B. PROCEDURE STEPS}

1. Remove Boron Filter and Pressure Tube

a. Raise and move the loop to the lower chuck.

b. Lower the loop into the lowe $r$ chuck to the proper position, and tighten jaws.

c. Slack off on crane cable and move crane as necessary to clear top of handling extension. 
d. Move upper carriage to bring the wrench to position over the loop.

e. Rotate lower chuck to bring one of the fasteners holding the handling extension to the loop into position under the wrench.

f. Lower the wrench, and unscrew the fastener.

g. Repeat, and unscrew the remaining fasteners.

h. Move upper carriage to clear the top of the loop.

i. With the crane, lift off the handling extension, move it to the storage rack and, with the manipulator, disengage the crane hook.

j. With the manipulator, move the lifting eye from the storage rack, and position it over the loop.

k. Rotate the lower chuck, and align the locating dowels of the loop with the holes in the lifting eye.

1. Lower the eye onto the loop.

$m$. Move the wrench into position, and tighten all fasteners in lifting eye lightly (monitor with torque indicator).

n. Torque up all fasteners to specified value.

o. With the manipulator, unhook the crane hook.

p. Move upper chuck into position over the loop, lower to working position at the top of the loop, and tighten jaws.

q. Using the cutting and gripping tool for the pressurizing line, cut off the end, taking care to relieve the pressure gradually, and deposit the cut end in the scrap container.

$r$. Move lower tool holder into position and advance the pressure tube cut-off tool to working position.

s. Clutch in the upper chuck, and cut off the boron filter and pressure tube.

t. Retract the cutting tool.

u. Raise the upper chuck, and draw the loop out of the filter. Move the loop clear of the lower chuck.

v. Clean lower chuck and surrounding area of chips with vacuum cleaner.

w. With manipulator, grasp cut-off end of pressure tube and filter.

x. Loosen chuck jaws, and remove filter to scrap containe $r$.
$-222-$
G-2 
2. Install New Boron Filter and Pressure Tube Section

a. With manipulator, place chip-catcher cover over lower chuck.

b. With upper chuck, move and position loop over lowe $r$ chuck at working height.

c. Position steady rest and clamp.

d. Move cutting and deburring tool to working position; clutch in lower chuck.

e. Machine lower end of pressure tube to specified contour.

f. Retract tool and steady rest.

g. Move loop clear of lower chuck.

h. Clean and remove cover from lower chuck.

i. With the manipulator, place new section of filter and pressure tube in proper position in lower chuck; clamp jaws lightly.

j. Energize heaters in cavity below the lower chuck, and allow sufficient time for the new section to heat up and expand.

k. Push loop down (if necessary) into new section until the halves of the joint are in proper position for welding.

1. Tighten lower chuck jaws and de-energize the heaters.

m. Move welding head into position.

n. Clutch in lower chuck, and begin rotation of the loop.

o. Begin welding, and complete first pass.

p. Stop welding, and move welding head away.

q. Move weld cleanup tool into position and prepare weld for liquid penetrant examination.

r. Make liquid penetrant examination.

s. If weld is satisfactory, proceed with remaining passes; if not, cut out defective portion, reweld, and re-examine until sound. Use carbide burr to remove defects.

t. After last pass is completed, repeat steps "q"-" $r$ ". If weld is sound, proceed with radiographic examination; if not rework per step "s".

u. Loosen jaws of lower chuck.

$v$. Raise the upper chuck and the loop, and move the loop to the $\mathrm{x}$-ray equipment. 
w. Make radiographic examination of the girth weld.

x. If weld is satisfactory, proceed with pressurizing and leaktesting. If weld is not satisfactory, cut out defective portions with burr, reweld, and repeat steps "o" - "w" until a satisfactory weld results.

$y$. Raise upper chuck and remove the loop from the $x$-ray equipment.

3. Pressurize, Leak-check, and Seal

a. With the upper chuck and carriage, move the loop to the lower chuck, lower it, and tighten lower chuck jaws lightly.

b. Raise and move the upper chuck and carriage to clear the top of the loop.

c. Move the crane into position and, with the manipulator, engage the crane hook into the lifting eye at the top of the loop.

d. Loosen the lower chuck jaws and raise the loop out of the lower chuck.

e. Move the loop to the transfer cask, and lower it into the cask.

f. Seal and decontaminate the cask.

g. Replace plug in floor of helium hot cell.

h. Transport cask to air hot cell, and seal to opening.

i. With the air hot cell crane, remove the plug in the floor.

j. With the crane, raise the loop from the cask, and place in the loop holding fixture at the pressurizing station.

k. Replace the plug in the floor.

1. With the manipulator, place silver-soldered coupling of the helium supply line over the cut end of the loop pressurizing connection.

m. Apply heat and solder the connection.

n. Open the helium supply valve, and build up helium pressure in the jacket, monitoring the pressure by the gauge.

o. When the pressure reaches the specified test pressure, shut the helium supply valve.

p. Make the helium leak-test of the girth seam at the top of the boron filter.

q. If test is satisfactory, bleed the pressure down to specified filling pressure. If not satisfactory, return to helium hot cell for rework. 
$r$. Move the pinch guillotine tool into position and pinch and cut the pressurizing tube.

s. Move cutter out of the way, but hold tube pinched until weld is completed.

t. Move welding head into position, and weld pinched end of tube.

u. Move welding head out of way.

v. With burr tool, prepare the weld for liquid penetrant test.

w. Make liquid penetrant test.

x. If weld tests satisfactory, proceed with helium leak-test. If weld shows defects, cut away with carbide burr tool, repressurize, reweld and retest until satisfactory.

y. Perform helium leak-test. If test is satisfactory, proceed with following steps. If weld is not satisfactory, cut out and rework.

z. With manipulator and wrench, unscrew the fasteners holding the lifting eye to the top of the loop and, with the crane move the lifting eye to the storage rack.

aa. With the crane, pick up the handling extension and move it to the top of the loop.

ab. With the aid of the manipulator, orient and lower it onto the loop.

ac. With the manipulator and wrench, tighten the fasteners holding the handling extension to the top of the loop.

ad. With the crane, lift the loop out of the holding fixture, and lower it into the storage pit, or into canal transfer cart. 


\section{I REMOVAL OF IRRADIATED SPECIMEN FOR EXAMINATION}

A. HANDLING OPERATIONS

1. Initial Conditions

a. The loop, with boron filter (in the case of the fast loop) and lower portion of the pressure tube removed in accordance with procedures described under "Removal and Renewal of Boron Filter and Pressure Tube", is in the helium atmosphere hot cell, suspended from the crane.

b. The lifting eye is attached to the top of the loop.

c. The parting and specimen removal device (Figure G-1) containing the proper amount of liquid metal and connected to the overflow container, is secured in proper position to the floor of the cell.

\section{B. PROCEDURE STEPS}

1. With the crane, move and lower the loop into the lower chuck.

2. Tighten the chuck jaws and remove crane.

3. Bring the cutting head into position and machine off the pressurizing connection, releasing the cover gas pressure over the liquid metal.

4. Move the cutting head.

5. With the manipulator, drop the cutoff portion of the pressurizing connection into the scrap container.

6. Move the upper chuck into position over the loop.

7. Lower the upper chuck over the loop.

8. Clamp the upper chuck jaws.

9. Loosen jaws of lower chuck and raise loop to position for machining groove in bottom closure.

10. With the manipulator, place the chip-catcher cover over the lower chuck.

11. Move the steady-rest into position and tighten.

12. Move the cutting tool into position.

13. Start the upper chuck and machine the parting groove in the bottom closure to the required depth.

14. Withdraw the cutting tool and stop the upper chuck. 
15. Loosen and withdraw the steady rest and remove the cover from the lower chuck.

16. Position the loop over the parting and specimen removal device.

17. Lower the loop until the bottom closure cap rests on the lower crosshead. (Monitor by motor current.)

18. Rotate the upper chuck until the threads of the bottom closure are completely engaged with those of the lower cross head. (Monitor by motor current.)

19. Lower carriage and upper chuck until upper crosshead rests on the shoulder inside the parting and specimen removal device. (Monitor by motor current.)

20. Energize the torque motor driving the differential screws in proper direction, to separate the crossheads and pull the bottom closure apart at the parting groove. (Monitor by motor current.)

21. Raise the upper carriage, drawing the loop off of the specimen.

22. After the loop has drained thoroughly, raise and move away for disposal (in the case of the fast loop), or to storage rack.

23. With the manipulator, bring the helium coolant adapter into position over the parting and specimen removal device, and start the flow of helium.

24. Lower the helium coolant adapter down over the specimen, and lock to the specimen.

25. Rotate the helium coolant adapter to unlock the specimen from the bottom closure cap.

26. Raise the helium coolant adapter and specimen out of the parting and specimen removal device as quickly as possible so that forced helium coolant will flow through the specimen.

27. Hold the specimen above the parting and specimen removal device until all liquid metal has drained off.

28. Move specimen and coolant adapter to examination area.

29. With the manipulator and special tool, remove the bottom closure cap from the parting and specimen removal device, and place in the storage rack. 


\section{I REPLACEMENT OF IRRADIATED SPECIMEN IN LOOP}

\section{A. HANDLING OPERATIONS}

1. Initial Conditions

a. Loop is in helium hot cell with lifting eye attached, and supported in upper chuck, with boron filter (in case of fast loop) and lower portion of pressure tube removed.

b. Specimen, locked in bottom closure cap, is in storage rack.

c. Loop helium cooling adapter is in storage rack.

d. Boron filter and lower portion of pressure tube are in storage rack in helium hot cell.

\section{B. PROCEDURE STEPS}

1. With the manipulator, take the loop helium cooling adapter from the storage rack and move to a position beneath and in line with the loop.

2. With the manipulator, raise the adapter, and slip over the lower end of the loop.

3. With the crane and manipulator, move the loop and adapter to the lowe $r$ chuck, lower, and clamp the lower end of the adapter in the chuck jaws.

4. Lower the upper chuck and loop until the loop projects the proper distance from the bottom of the cooling adapter, and with the manipulator, clamp the adapter to the loop.

5. Start flow of helium through the cooling adapter and, with the manipulator, check to insure that the swivel connection at the top of the cooling adapter turns freely.

6. Loosen jaws of the lower chuck, and raise the loop and cooling adapte $x$ out of the chuck and move to clear.

7. With the manipulator, take the bottom closure adapter from the storage rack and place it in the lower chuck; tighten the chuck jaws.

8. With the manipulator, take the test specimen and bottom closure from the storage rack, and move to the lower chuck.

9. Lower the specimen and rotate the lower chuck so as to screw the bottom closure into the bottom closure adapter until it bottoms.

10. Raise the loop and helium cooling adapter, move in line with the specimen, and lower over the specimen until the two halves of the joint are in proper position for welding. 
11. Move the welding head into position.

12. Clutch in both chucks, and rotate both the loop and the test specimen together.

13. Begin welding, and continue until one pass is completed.

14. Withdraw the welding head.

15. Move in the weld clean-up tool and prepare the weld for liquid penetrant examination.

16. Make liquid penetrant examination.

17. If the weld is satisfactory, proceed with welding; if not, cut out defective areas with the carbide burr, reweld and re-examine until satisfactory.

18. Move the welding head back in, and complete the remaining passes.

19. Withdraw the welding head, move in the clean-up tool and prepare the weld for liquid penetrant examination.

20. Make the liquid penetrant examination. If the weld is satisfactory, proceed with the radiographic examination; if not, cut out defective portions, reweld and re-examine.

21. Declutch and set the brake on the upper clutch.

22. Reverse the lower clutch, and unscrew the bottom closure from the bottom closure adapter.

23. Release the brake on upper clutch, raise the clutch and loop, and move to $x$-ray equipment.

24. Make the radiographic examination.

25. If the weld is satisfactory, proceed with the liquid metal filling (See "Filling with Liquid Metal, Pressurizing and Sealing). If the weld is not satisfactory, cut out the defective portions, reweld, and make the liquid penetrant and radiographic examinations as described previously.

26. With the manipulator, remove the bottom closure adapter from the lower chuck, and return to the storage rack. 
IV FILLING WITH LIQUID METAL, PRESSURIZING AND SEALING

A. HANDLING OPERATIONS

1. Initial Conditions

a. Loop suspended in upper chuck in helium atmosphere hot cell with lifting eye attached.

b. Loop helium cooling adapter in position over lower end of liquid metal containment tube, with helium circulating.

c. Container with measured quantity of liquid metal connected to helium pressurizing supply with supply valve closed and loop filling line attached.

d. Liquid metal filling connection and He pressurizing connection are cut and prepared for use; connections long enough to allow for cutting off the ferrule after filling.

\section{B. PROCEDURE STEPS}

1. Refill with liquid metal

a. With the manipulator, place the compression coupling of the liquid metal filling line over the filling connection.

b. With the manipulator and wrench, tighten the coupling.

c. With the manipulator, open the valve in the high-level outlet of the liquid metal container.

d. With the manipulator, open the helium pressurizing valve, admitting pressure to the top of the liquid metal container.

e. Monitor the pressure by the helium pressure gauge, and when a drop in pressure indicates that the liquid metal level in the container has fallen below the upper outlet, and the test specimen is submerged in liquid metal, shut off the helium pressurizing valve and the high level outlet valve.

f. With the manipulator, place the compression coupling of the vacuum-pressure wye-connection over the end of the helium pressurizing connection, and tighten.

g. Open the valve of the vacuum line and evaculate the liquid metal spaces, monitoring by the vacuumgauge. Purge with helium, evacuate and repeat as necessary to ensure removal of contaminants in liquid metal spaces in loop.

$h$. Open the low-level outlet valve on the liquid metal container, and by combined pressure and vacuum transfer the remainder of the charge of liquid metal to the loop.

i. Close the low-level outlet valve and the vacuum valve. 
2. Pressurize and Seal Liquid Metal Space

a. Open the helium pressurizing valve and pressurize to the specified pressure, monitoring the pressure by the gauge.

b. Close the helium pressurizing valve.

c. With the manipulator, move the pinch-tool into position, and pinch the liquid metal filling line below the coupling.

d. While holding the tube closed, bring the cutter into position, and cut the tube between the pinch portion and the coupling.

e. Move the welding head into position and weld the cut end of the tube.

f. Remove the pinch-tool.

g. Pinch, cut, and weld the helium pressurizing tube in similar manner.

h. With the carbide burr, prepare both welds for liquid penetrant examination.

i. Make liquid penetrant examination of both welds. If both are sound, proceed with radiographic examination. If not, cut out defective weld, repressurize, and re-examine until sound welds are secured.

j. Move $x$-ray head into position and make radiographic examination of both welds. If welds check sound, proceed with helium leaktest; if not, cut out defective welds and rework.

$k$. With the upper chuck, move the loop and lower it into the lower chuck.

1. Tighten the jaws of the lower chuck, loosen those of the upper, raise the upper chuck, and move to clear the loop.

$m$. With the manipulator, slip the rubber grommet over the inner double containment tube, slide it down into the outer tube, sealing the opening to the liquid metal spaces.

n. With the manipulator, place the protective rubber cap over the liquid metal and $\mathrm{He}$ connections and over the end of the inner containment tube, sealing the opening into the stagnant helium space. Note: Rubber grommet and cap are temporary seals to prevent collection of water in depressions during decontamination.

o. With the crane, raise the plug in the floor over the transfer cask, and set it a side.

p. Engage the crane hook in the lifting eye of the loop and take up slack. 
q. Stop flow of helium through the loop helium cooling adapter.

r. Loosen lower chuck jaws, and lift loop and adapter out of chuck.

s. Lower until the cooling adapter rests on the floor and, with the manipulator, unclamp and grasp the adapter.

t. Raise the loop, place in the transfer cask, and unhook.

u. With the manipulator, place the cooling adapter in the storage rack.

v. Seal the cask and decontaminate the cask and loop.

w. With the crane, replace the plug in the floor.

$x$. Unseal and move the transfer cask to air atmosphere hot cell, and seal to the floor.

y. With the crane, lift and set aside the floor plug.

$z$. Unseal the cask, engage the crane hook in the lifting eye, and lift the loop.

aa. Move the loop and place in holding fixture; unhook crane hook.

ab. With the manipulator, remove rubber cap and grommet.

ac. Purge cooling and stagnant helium spaces with inert gas.

ad. Make helium leak test of both welds; if satisfactory, proceed with next operation. If unsatisfactory, rework in helium atmosphere.

ae. With the crane, remove the floor plug.

af. Move and lower the loop into the cask, and seal and purge the cask with helium.

ag. Replace the floor plug.

ah. Move the cask to the helium atmosphere hot cell and seal to the floor.

ai. Remove the floor plug in the helium atmosphere hot cell.

aj. Unseal the cask, and raise the loop into the cell.

ak. Replace the floor plug.

al. Purge the helium spaces with helium.

am. Weld on the double containment cap over the liquid metal filling line and the helium cover gas pressurizing line.

an. Make liquid penetrant test of the weld; if satisfactory, proceed with the next operation. If not, rework the weld. 
ao. Make radiographic inspection of the weld, if satisfactory, proceed with the next operation. If not, rework the weld.

ap. Weld on the outer cap over the double containment cap.

aq. Make liquid penetrant and radiographic inspections of the weld.

ar. When weld checks satisfactory, proceed with installation of lower section of pressure tube and (for fast loop) the boron filter, in accordance with procedures in "Removal and Renewal of Boron Filter and Pressure Tube." 


\section{DESCRIPTION OF HOT CELL EQUIPMENT AND SERVICES REQUIRED}

\section{HELIUM A TMOSPHERE HOT CELL - PERMANENTLY INSTALLED EQUIPMENT}

\section{a. Overhead Carriage and Upper Chuck}

The overhead carriage carries the upper chuck and the various tools required for operations on the top of the loop. The tools include wrenches, cutting heads and positioning fixtures. The upper chuck, in addition to rotating the loop for cutting and welding operations, also serves as a precision positioning device after shifting the loop from one work station to another. The rotary motion of the chuck is required only when it is positioned in line with the lower chuck, and in that position it may be driven from the same drive train as the lower chuck. It is of adjustable speed and is capable of a high order of accuracy and constancy of speed as required by the welding operation. When clutched in, the speed of both chucks is identical at all times. Stopping the drive motor automatically sets a brake on the drive train. The carriage has horizontal and vertical motions powered by torque motors and provided with automatic breaking. Horizontal motion is $10 \mathrm{ft}$ and vertical $7 \mathrm{ft}$. Maximum height from hot cell floor to top of upper chuck is $23 \mathrm{ft}$. The torque motor drives permit accurate positioning of the chuck by bringing it up firmly against stops. Chuck speed and power are a maximum of $1 \mathrm{HP}$ at 5 RPM. A fractional HP torque motor operates the jaws.

\section{b. Lowe r Chuck}

The lower chuck, with the upper chuck, drives both sections of the loop during welding of liquid metal containment and pressure tubes, thus eliminating the need for tack welding prior to the first pass, and holds both portions rigidly aligned for both welding and cutting operations. In addition, it serves as a supporting and clamping fixture for various other operations. Like the upper chuck, it is of the universal or scroll type with torque motor operating the jaws.

The lowe $r$ clutch, with supporting base and the common drive for both clutches, is bolted to the floor. Area required is $42 \mathrm{in}$. along the wall by 18 in. deep by 60 in. high.

The base has a central cavity lined with electric heaters for expansion of the boron filter and pressure tube section during replacement. Cavity temperature is monitored by remote read-out thermometers.

\section{c. Parting and Extracting Device}

The parting and extracting device shown as specimen removal concept II (Fig. G-1) performs the function of applying sufficient force (by tension alone) to part the bottom closure cap from the liquid metal containment tube at the previously machined parting groove. It is powered by a torque motor of not more than 1/2 HP. Floor space required is $30 \mathrm{in.}$ along the wall by $18 \mathrm{in.} \mathrm{deep} \mathrm{by} 60 \mathrm{in.} \mathrm{high.}$ 


\section{d. Lower Tool Holder}

The lower tool holder carries the tools required for operations at the lower end of the loop. These include the cutting tools for preparation of joints to be welded, for cleaning up welds to be inspected by liquid penetrant, for machining parting grooves, and for cutting off pressure tubes and filters. It carries the steady rest, and a fixture for supporting and aligning the welding head. A fractional HP motor furnishes power for positioning and feeding. Working volume is confined to the area above the lowe $r$ chuck.

\section{HELIUM ATMOSPHERE HOT CELL - PORTABLE EQUIPMEN T}

\section{a. Bottom Closure Adapter}

The bottom closure adapter is designed to prevent crushing or damaging the threads of the bottom closure during the operations of assembling and welding the bottom closure of the loop. It is a thick-walled cup with female threads matching those of the bottom closure, and is held in the jaws of the lower chuck during installation of the test specimen into the loop.

\section{b. Loop Helium Cooling Adapter}

The loop helium cooling adapter provides cooling of the $\mathrm{NaK}$ containment tube and of the test specimen during the time when an irradiated specimen is in the tube but not immersed in NaK. It consists of a suitably baffled sleeve or jacket which can be slipped over the in-core portion of the $\mathrm{NaK}$ containment tube and clamped in place. Inert gas is led into the adapter through a swivel connection which permits rotation of loop and adapter while helium is being circulated.

\section{c. Test Specimen Helium Coolant Adapter}

The test specimen coolant adapter provides a stream of coolant through the irradiated specimen when it is first removed from the loop and no longer covered with $\mathrm{NaK}$. It consists of a flexible hose connection which conducts helium under blower pressure into the top of the specimen whence it flows down through the spaces between the fuel rods and between the rods and the shroud. A split clamp at the end of the flexible hose permits locking to the top shroud ring of the test specimen. In addition to its cooling function, it is also used to lift the test specimen from the parting and extracting device.

\section{d. Chip-Catcher and Cover}

The chip-catcher and cover is designed to cover the lower chuck and prevent chips from falling into the cavity beneath the chuck during machining operations when the chuck is not in use. These include preparation of the lower end of $\mathrm{NaK}$ containment and pressure tubes

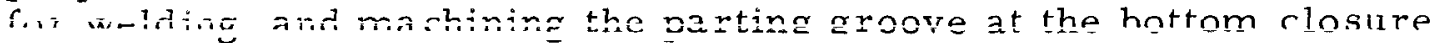
of the NaK containment tube. It is fabricated of light-gauge stainless steel with provision for placing and removing by the manipulator.

$$
G-15
$$




\section{e. Carbide Burr Tool}

This tool is used to clean up welds for dye penetrant examination, and to remove small localized defects in welds. It is a standard commercial pencil-type grinder chucking a carbide burr and revolving at high speed. It may be handled by the manipulator or clamped in a fixture on the tool-holder. 


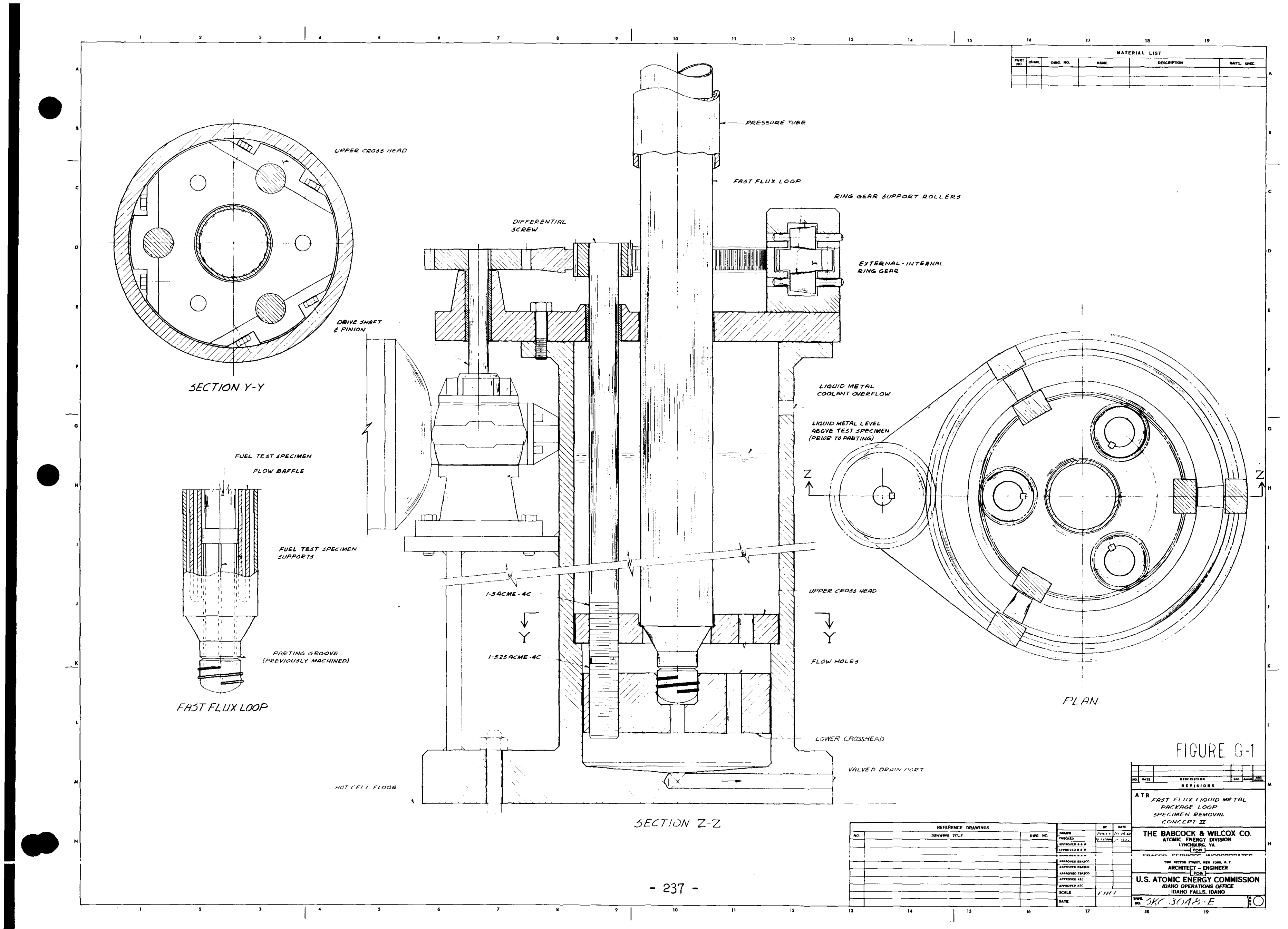


- 


\section{APPENDIX $\mathrm{H}$}

Fast Flux Liquid Metal Package Loop

Thermal Analysis for Specimen Handling 
0

o 


\author{
THE BABCOCK AND WILCOX COMPANY \\ FOR EBASCO SERVICES INC. \\ DESIGN DATA \\ ADVANCED TEST REACTOR \\ FAST FLUX LIQUID METAL PACKAGE LOOP \\ THERMAL ANALYSIS FOR SPECIMEN HANDLING
}

\title{
Purpose and Scope
}

The purpose of this Design Data Sheet is to present the results of the following investigations concerning the fast flux test specimen when it is removed from the loop:

1. Helium requirements for cooling the specimen when the shroud is around specimen.

2. Helium requirements for cooling the specimen when the shroud is not around the specimen.

3. Rate of temperature rise when the specimen has no cooling.

4. Maximum specimen heat flux as a function of time after removal from the reactor.

\section{$\underline{\text { Description }}$}

To perform the investigations listed in the previous paragraph, the following set of assumptions was made:

1. The specimen has been irradiated for 2,000 and 10,000 hours.

2. The helium flow must be sufficient to prevent the maximum specimen surface temperature from rising above $1000 \mathrm{~F}$.

3. The axial heat flux was assumed to follow a cosine curve (See Figure $\mathrm{H}-1$ ). This assumption is considered to be sufficiently accurate for this investigation.

4. The helium was assumed to enter the high heat flux end of the specimen at $100 \mathrm{~F}$.

5. The radial flux distribution was considered to be constant across the specimen. This is a valid assumption due to the small number of nins and small radial and angular variation in the specimen. 
6. The decay heat curve for the specimen is discussed and shown in Appendix A.

The following basic information concerning the specimen was obtained from the Design Objectives.* (See Figure 4.1, IDO 24041, Design Criteria for a Fast Flux Liquid Metal Loop in the Advanced Test Reactor, for details.)

100\% Specimen Fission Power - . $151 \mathrm{kw}$

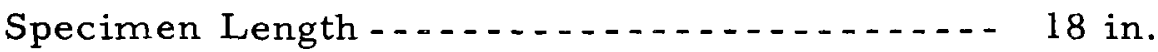

Pin O. D.

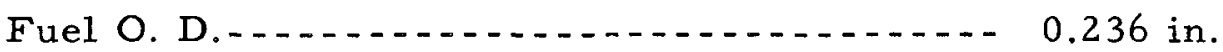

Pin Geometry - . Triangular Pitch, Spiral Spacers

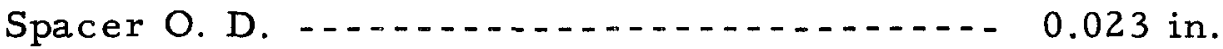

Pin Clad Material

1. Helium Requirements With Shroud Around Specimen

Sketch SKC-2894 (Figure H-6) shows a possible arrangement for cooling the specimen with helium when the shroud is around the specimen. This sketch shows a hose connection feeding helium into the specimen but no hose on the outlet. It has been assumed that the loop feeding the specimen is open to the hot cell. The cooling requirements for a closed loop would be the same as for an open loop.

The helium requirements were calculated by first assuming the specimen to be divided into 3 inch increments. The maximum temperature was calculated for each section by performing a heat balance on the section for several assumed helium flows and an assumed heat load. The helium flow was thus found that results in a maximum specimen surface temperature of $1000 \mathrm{~F}$. A $100 \mathrm{~F}$ safety factor was included in the flow determination in order to provide a factor of safety for the inaccuracies involved in the calculations, for the assumption of a constant radial heat distribution, and for the assumption of an average flow distribution in the specimen.

The previous calculations were repeated for several other assumed heat loads. Figure H-2 shows the resulting heat load vs.

* Contained in letter dated April 4, 1962, from H. M. Leppich to R. H. Gordon. 
helium flow required to maintain a $1000 \mathrm{~F}$ specimen surface temperature. By using Figure $\mathrm{H}-2$ in conjunction with the specimen decay heat curve (Shown in Appendix A) the helium requirements vs. time were determined. Figure $\mathrm{H}-3$ shows the helium requirements for specimen ir radiation times of 10,000 hours and 2,000 hours. In developing Figure $\mathrm{H}-3$ from the decay heat curve and from Figure $\mathrm{H}-2$, a $25 \%$ safety factor was applied to the actual specimen fission power of $151 \mathrm{kw}$.

Figure $\mathrm{H}-2$ also contains a curve showing helium pressure drop for the specimen with the shroud in place. The analysis for this curve considers the total specimen pressure drop to consist of fuel pin pressure drop and drag losses due to the spiral wound spacers. The fuel pin pressure drop was calculated by the standard Darcy formula. The spacer head loss was based on a formula presented in the June, 1961, issue of "Nucleonics".*

2. Helium Requirements With No Shroud Around Specimen.

Sketch SKC-2913 (Figure H-7) shows a possible arrangement for cooling the specimen with helium when no shroud surrounds the specimen. The helium requirements for this arrangement were estimated from work performed at Argonne National Laboratory (ANL) and reported in the December, 1956, issue of "Nucleonics".**

This article contains the results of an experimental program that was conducted with an electrically heated fuel bundle with 91 pins in which a gas was first blown across the bundle in a manner similar to that in SKC-2913 and then was blown longitudinally through the bundle in a manner similar to SKC-2894. The longitudinal flow was approximately the same as for the case with the flow across the bundle when the gas flow and heat loads were approximately the same.

Relating this work to the specimen of concern in this design data sheet indicates that approximately the same helium flow would be required with the shroud off as is required with the shroud on. This should be a conservative analogy since only 7 pins are in. volved in this specimen as compared to 91 pins in the ANL specimen.

The ANL experimental work can also be used to give an indication of the pressure drop that can be expected with flow across the

* "Drag Coefficients for Fuel Element Spacers", A. N. deStordeur, BelgoNucleaire S.A., Brussels Belgium, June 1961, "Nucleonics".

** "Decay Heat Cooling Requirements of Spent Fuel From EBR-2", by C. H. Scheibelhut, Argonne National Laboratory, Necember 1yjo, "Nucleonics". 
bundle. In the experimental work a full scale assembly of a 91 pin specimen was used to determine the pressure drop due to a gas flowing across the fuel pins. It was found that less than 2 inches of water pressure drop occurred with $15 \mathrm{cfm} *$ of helium flowing through the holder and across the bundle.

3. Rate of Temperature Rise With No Forced Cooling

The ANL experimental work discussed in the previous section indicates that when the pins are separated from the bundle no forced cooling is necessary. Until they are separated, however, the temperature will rise rapidly when there is no forced cooling.

Calculations were made to determine the rate of temperature rise in the specimen as a function of decay time with no cooling. For this analysis it was assumed that the specimen was in an adiabatic condition, that is, all decay heat was considered to go toward raising the specimen temperature. Figure $\mathrm{H}-4$ is a set of curves showing the results of these calculations.

4. Maximum Specimen Decay Heat Flux

Figure $\mathrm{H}-5$ is a curve of maximum specimen heat flux vs. time and is presented for general information. This curve was developed by using the decay heat curve (Appendix A) and a maximum hot spot heat output of $2 \mathrm{kw} /$ inch which is specified in IDO 24041 "Design Criteria For a Fast Flux Liquid Metal Loop in the Advanced Test Reactor".

\section{Results and Conclusions}

The analyses in many cases were based on assumed conditions to aid in establishing handling procedures. It is almost certain that the conditions corresponding to actual handling procedures will be different. However, the results presented can be used as a guide.

Since consideration is being given to using argon in the inert atmosphere hot cell, a rough comparison of the cooling requirements for argon and helium indicates:

(1) The weight flow of argon would be approximately twenty (20) times the required helium weight flow.

(2) The volume flow of argon would be approximately two (2) times the required volume flow of helium.

(3) The pressure drop for argon would be approximately twenty (20) times that of the helium.

* Density $-0.005 \# / f t^{3}$ 
The analysis of the specimen with the shroud around the specimen was made for the cooling connection being on the end of the specimen with the highest heat generation rate. If the connection were made to the other end, the helium flow requirements would increase about $50 \%$.

The amount of helium required to cool the specimen is shown in Figure $\mathrm{H}_{-}$3. To use this curve, enter the horizontal axis with the decay time, rise vertically to the specimen irradiation time and then project the point horizontally to the vertical axis where the required helium flow can be read. The curve shows that after one day of decay, for 10,000 hours irradiation time, the required helium is $15 \mathrm{cfm}$. The helium requirements decrease rapidly to approximately $4 \mathrm{cfm}$ at 7 days decay time. After 7 days decay time the helium requirements decrease slowly with $1 \mathrm{cfm}$ required at 30 days. The helium can be forced longitudinally through the specimen with the shroud in place or can be forced across the specimen with the shroud not in place with approximately the same results.

Once the required helium flow is found as described above, the heat load and specimen pressure drop corresponding to this flow can be found. This is done by entering the horizontal axis of Figure H-2 with the helium flow and then projecting the point up to the proper curve to read either the heat load or specimen pressure drop on the vertical axis. The specimen pressure drop can be used in sizing the helium pumping system and the heat load can be used in sizing the system that is us ed to cool the helium.

With no forced cooling the specimen temperature rises rapidly when the fuel pins are in a bundle. For example, entering Figure $\mathrm{H}-4$ at a decay time of one month gives a temperature rise of $120 \mathrm{~F} / \mathrm{min}$. for an ir radiation time of 10,000 hours. Thus, if the s pecimen were cooled to approximately $300 \mathrm{~F}$ before forced cooling was stopped, then in approximately 6 minutes the specimen would be at the maximum allowable surface temperature of $1000 \mathrm{~F}$. This means that very little time is available for work requiring no forced cooling when the fuel pins are in a bundle. On the other hand, no forced cooling is required after the pins are separated.

\section{Title I Work}

The results of this investigation should not be taken as final. Rather, this is intended to be used as a guide in directing Title I work in specimen handling. This work would consist of a more thorough study of forced cooling of the specimen, utilizing a digital computer to solve the most complex parts of the problem. Experimental work might be required to gain a more accurate picture of specimen cooling by natural convection. Any studies of specimen handling in Title I would be performed based on a decay heat curve for a plutonium-uranium specimen. Since this curve is not presently available, it would have to be developed in Title I. 
A more detailed analysis, with possible experimental work, may be required in Title I to obtain more accurate values of specimen pressure drop for the cases of both longitudinal and cross flow. This would be necessary in order to accurately size the helium supply system. It may be more advantageous, however, to over-size the helium pumping system and to specify helium flows for different decay perits that would give cons ervative results.

\section{APPENDIX A \\ ATR FAST LOOP SPECIMEN HEAT FLUX AFTER IRRADIATION}

At any time after normal in-pile loop operation, the heating of the individual fuel pins caused by decay heat from fission products must be limited to prevent post-irradiation changes in the metallurgical properties of the fuel. Heat is produced in natural uranium after reactor shutdown by the following methods: (1) fissions from delayed neutrons, (2) decay of radioactive fission products, and (3) decay of U-239 and Np-239. Since the first item becomes insignificant within a few minutes after shutdown, the last two items are the only ones considered. A typical fission product decay curve for natural uranium was used as the basis for calculating the maximum specimen heat flux during the fission product decay period after irradiation. Figure H-8 is a curve of total decay power versus cooling time and is based on results from Untermyer and Weills.* This curve includes the effect of $\mathrm{U}-239$ and $\mathrm{Np}-239$ but does not include the effect of the plutonium enrichment in the fuel specimen. The effect of the plutonium enrichment will be studied in detail in Title I. The values shown on the attached curve are judged sufficiently accurate for this analysis.

* Untermyer and Weills, Table 33. "Decay Heat Rate of Fission Products", H. Etherington, Ed., Nuclear Engineering Handbook, p. 1-39, McGrawHill Book Co., Inc., 1958. 


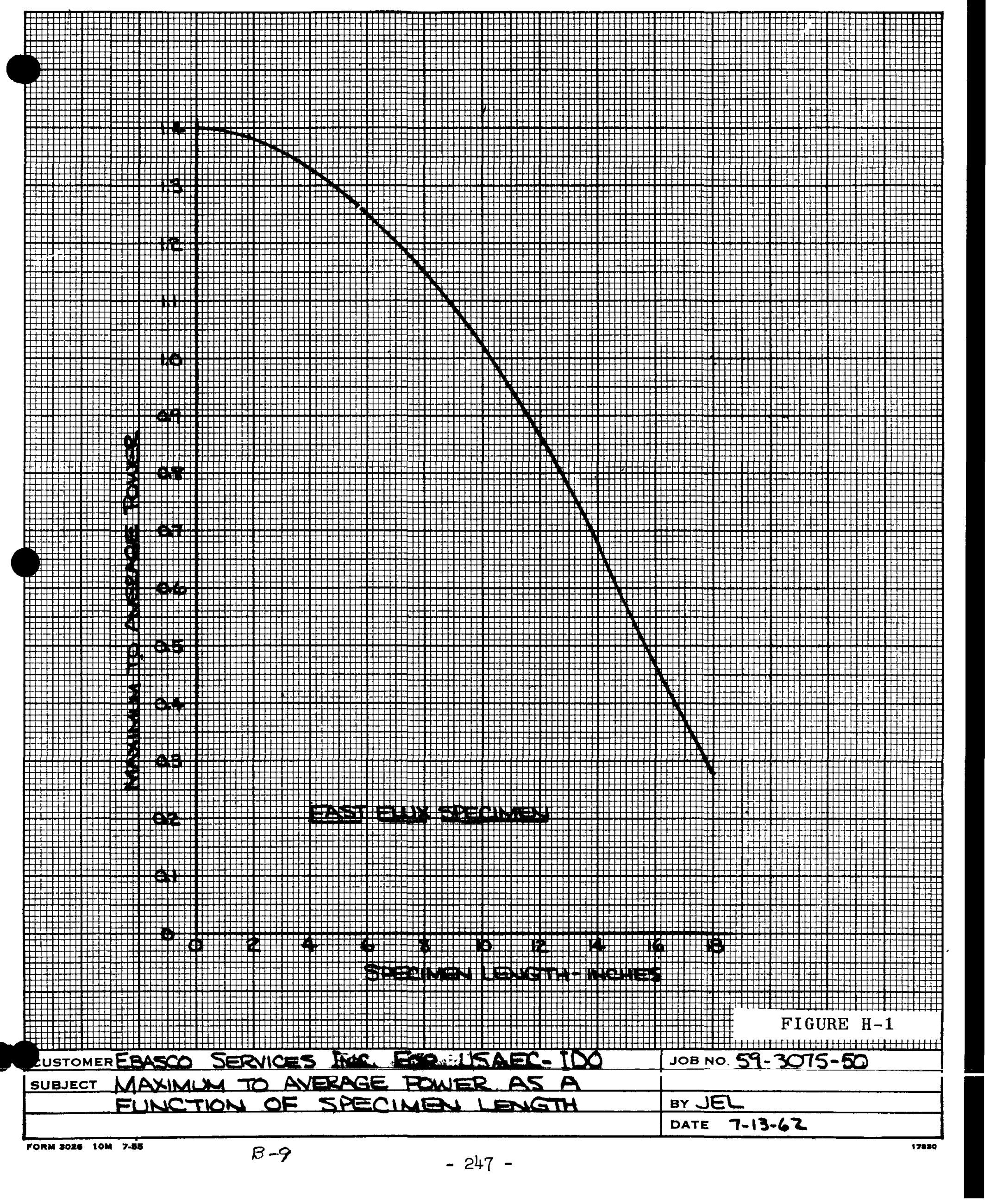




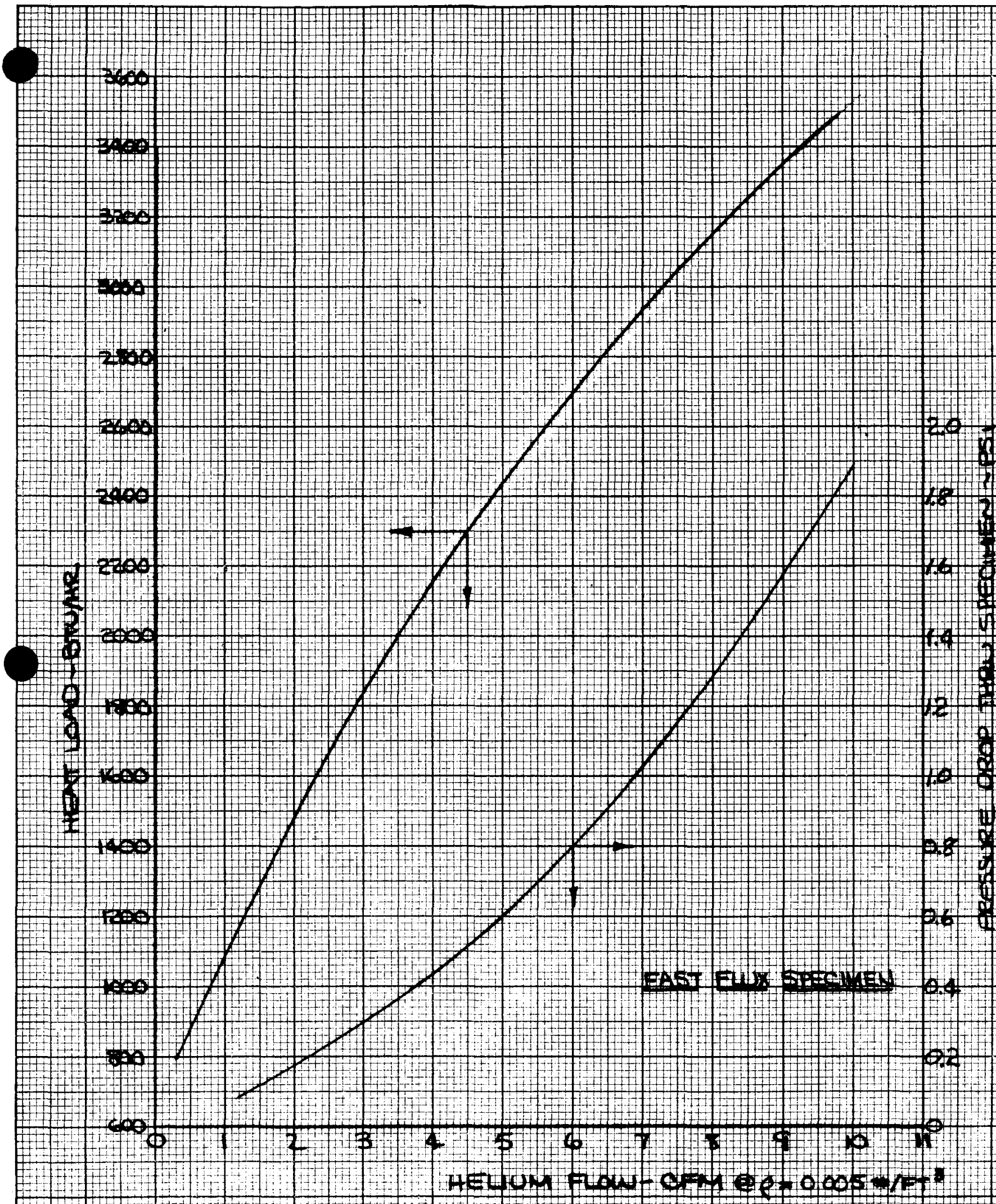

FIGURE $\mathrm{H}-2$

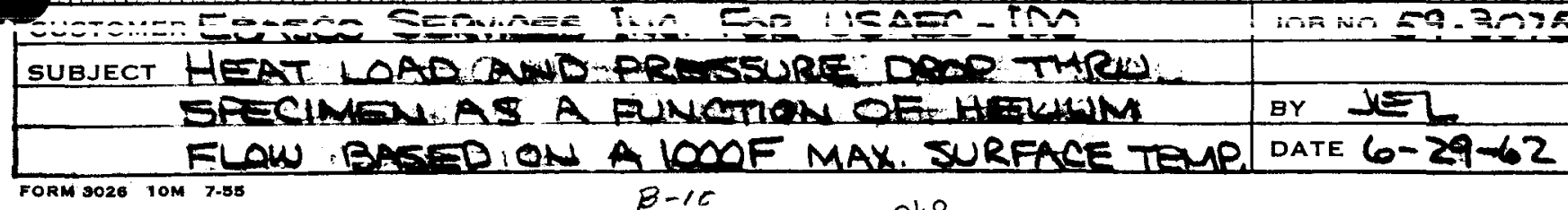




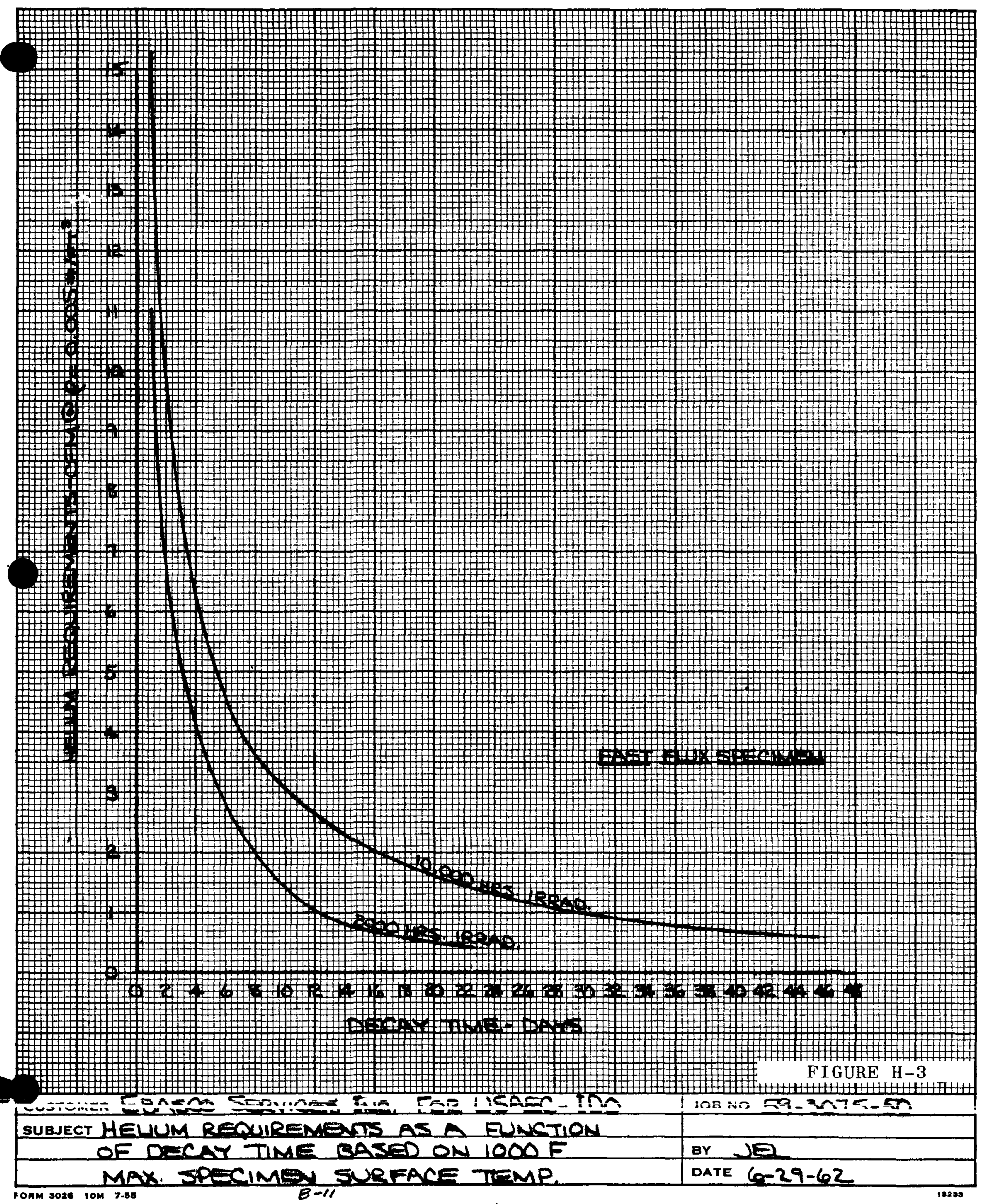




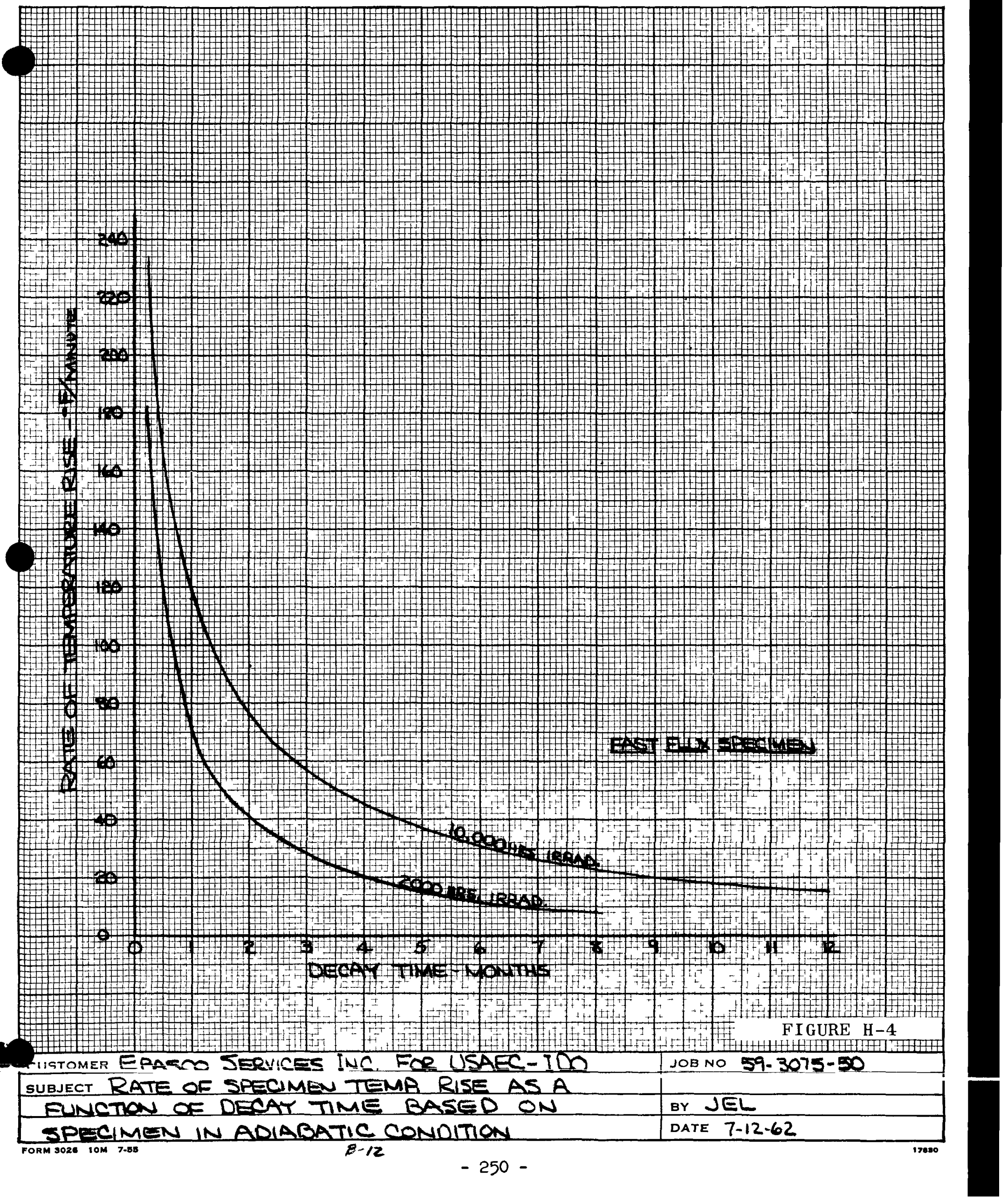




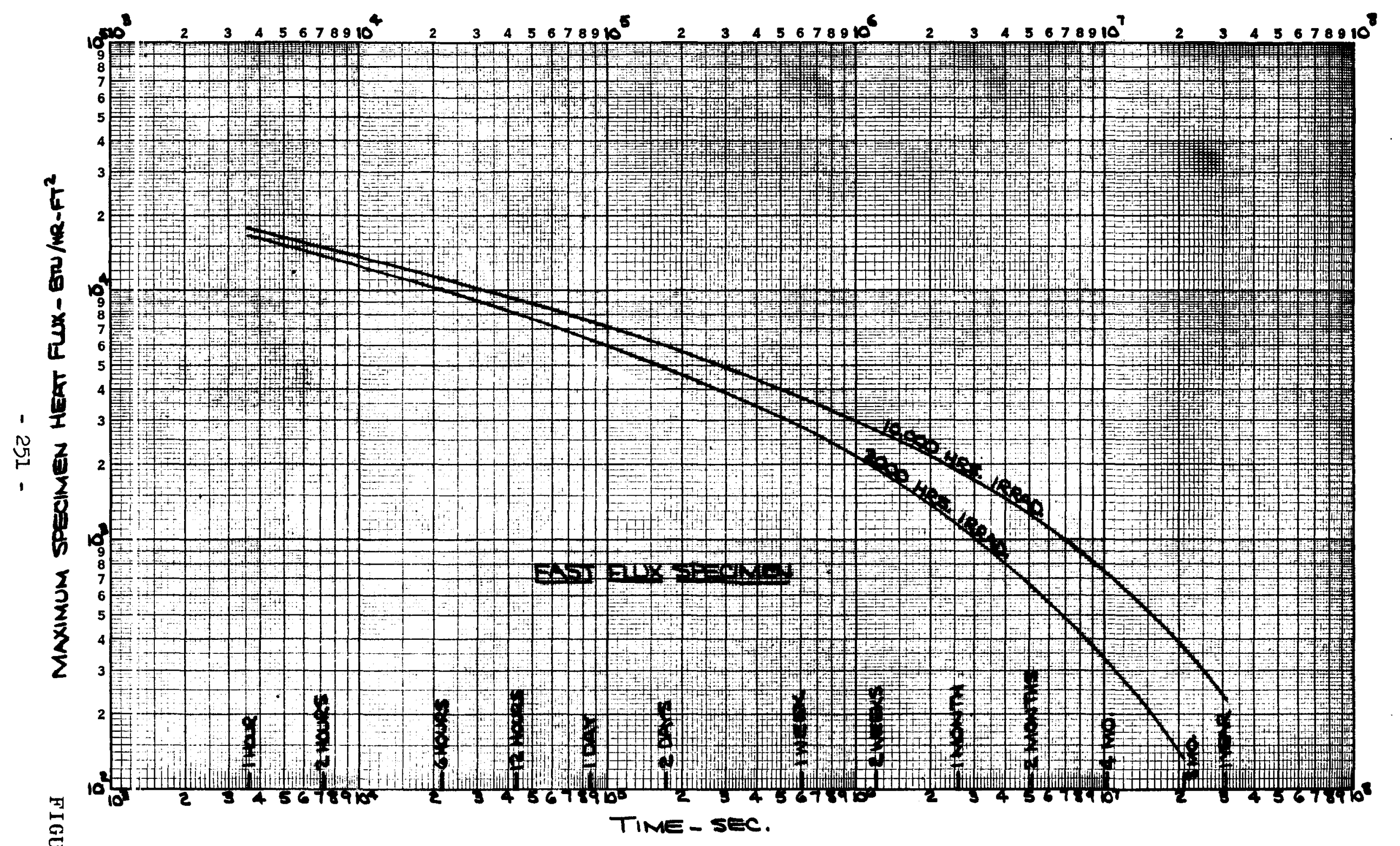

CUSTOMER- EbASCO SERVICES INC. FOR USAEC-IDO

SUBJECT- MAXIMUM SPECIMEN HEAT FUX AS A FUNCTION OF TIME

FIGURE 5 


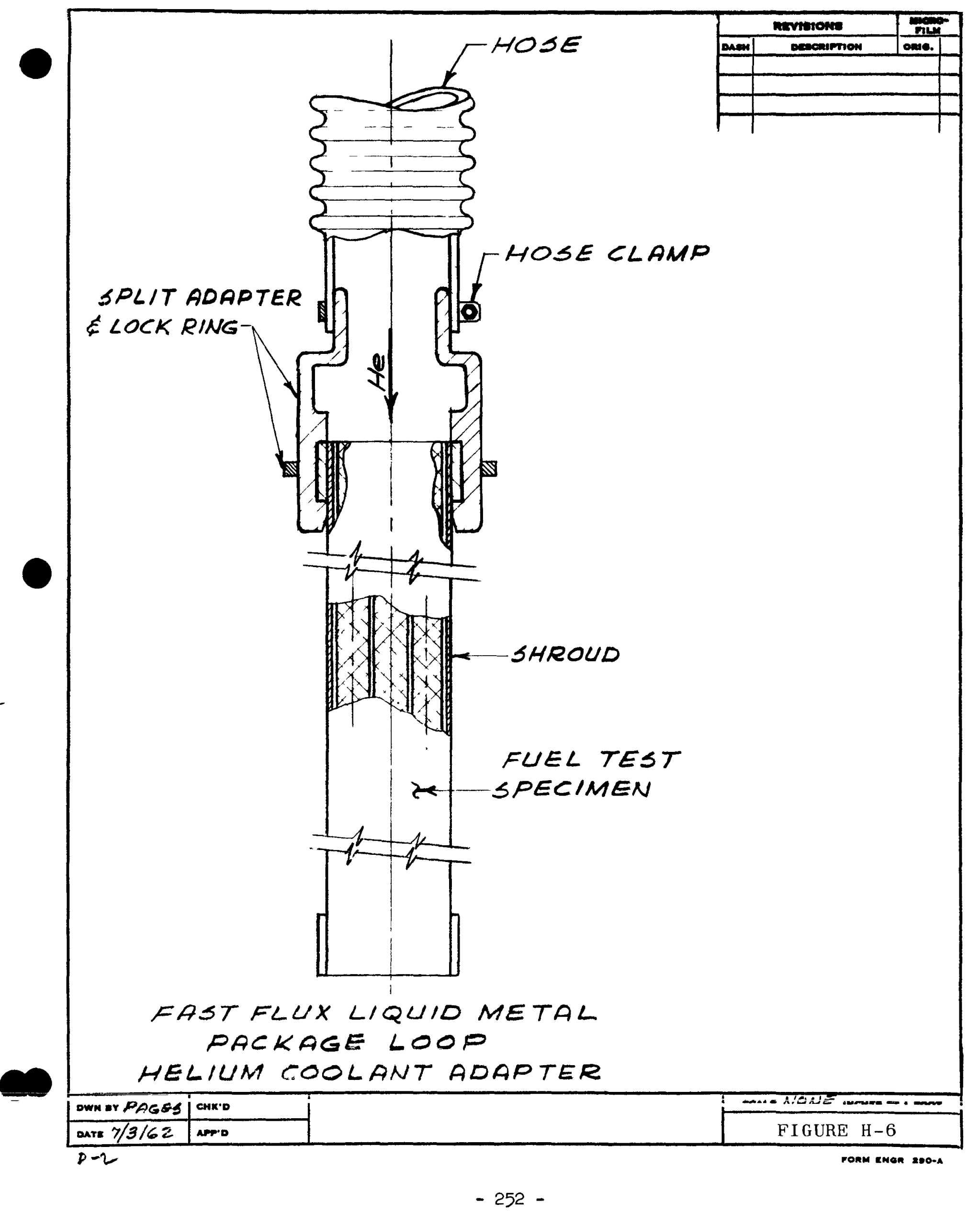




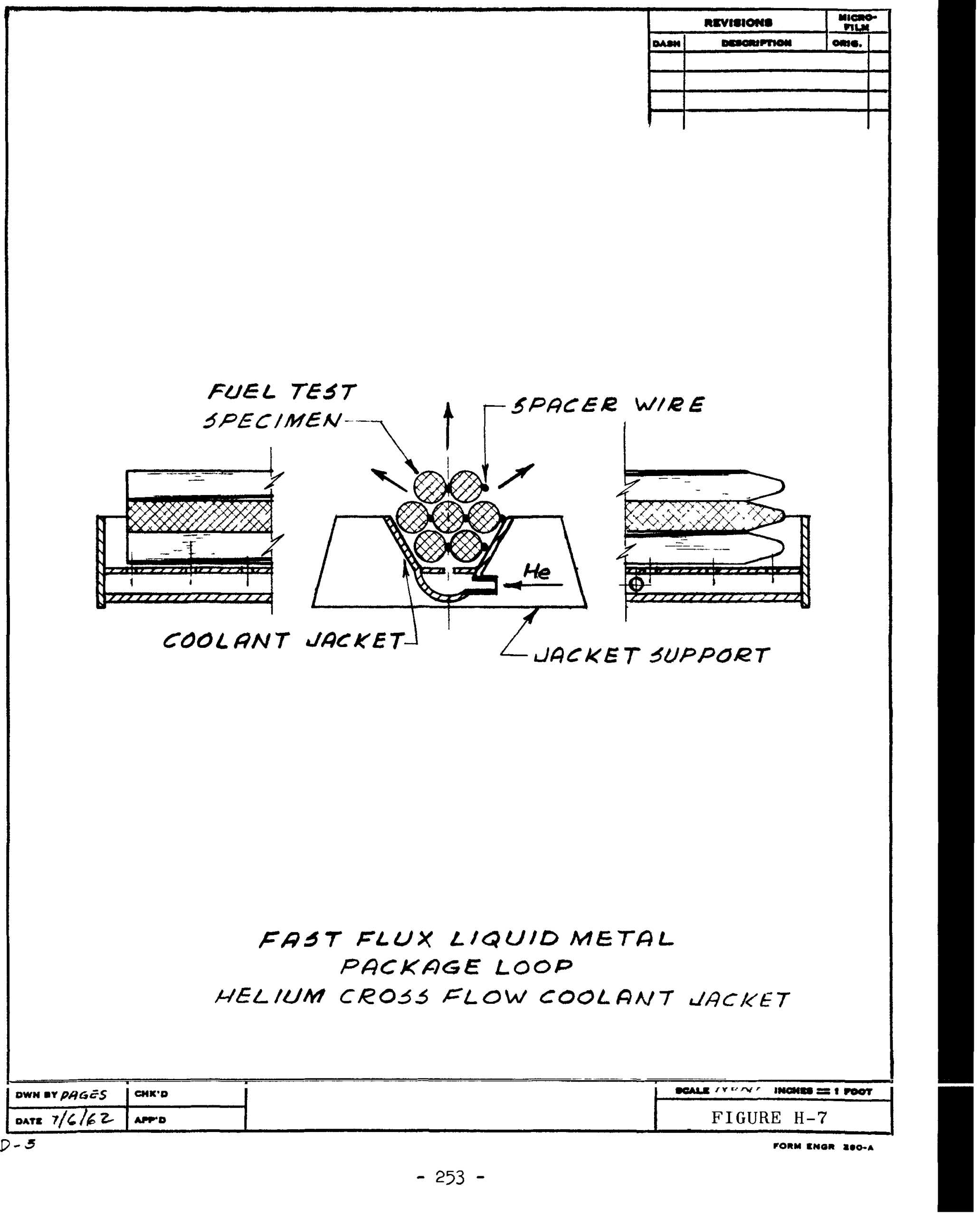




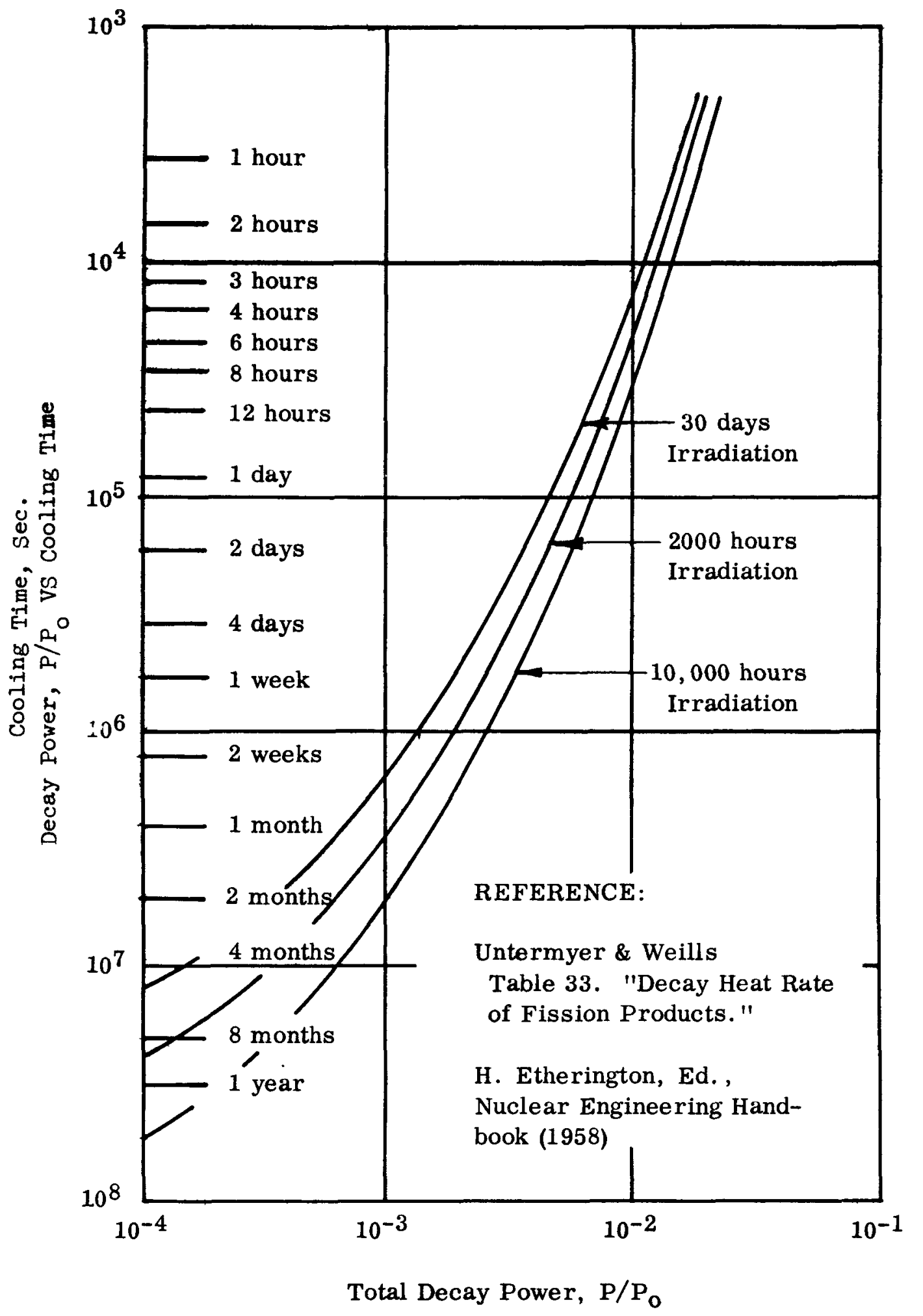

FI GURE H-8 
8 
APPENDIX I

Thermal Flux Liquid Metal Package Loop

Thermal Analysis for Specimen Handling 


\section{THE BABCOCK AND WILCOX COMPANY \\ FOR EBASCO SERVICES INCORPORATED \\ DESIGN DATA \\ ADVANCED TEST REACTOR \\ THERMAL FLUX LIQUID METAL PACKAGE LOOP \\ THERMAL ANALYSIS FOR SPECIMEN HANDLING}

\section{Purpose and Scope}

The purpose of this Design Data Sheet is to present the results of the following investigations concerning the thermal flux test specimen when it is removed from the loop:

(1) Helium requirements for cooling the specimen when the shroud is around the specimen.

(2) Helium requirements for cooling the specimen when the shroud is not around the specimen.

(3) Rate of temperature rise when the specimen has no cooling.

(4) Maximum specimen heat flux as a function of time after removal from the reactor.

\section{Description}

To perform the investigations listed in the previous paragraph, the following -set of assumptions was made:

(1) The specimen has been irradiated for 2,000 and 10,000 hours.

(2) The helium flow must be sufficient to prevent the maximum specimen surface temperature from rising above $1,000 \mathrm{~F}$.

(3) The axial heat flux was assumed to follow a cosine curve (see Figure I-1). This assumption is considered to be sufficiently accurate for this investigation.

(4) The helium was assumed to enter the specimen at $250 \mathrm{~F}$. This temperature was selected as a safe temperature to use that will avoid local freezing of sodium when the specimen is being handled.

(5) The radial flux distribution was considered to be constant across the specimen. This is a valid assumption due to the small number of pins and small radial and angular variation in the specimen.

(6) The decay heat curve for the specimen is discussed and shown in Appendix A. 
The following basic information concerning the specimen was obtained from the Design Objectives.* (See drawing SKC-2972E for details of specimen.)

$\begin{array}{ll}100 \% \text { specimen fission power } & 1500 \mathrm{kw} \\ \text { Specimen length } & 48 \\ \text { Pin O. D. } & 0.56 \mathrm{in.} \\ \text { Fuel O. D. } & 0.50 \mathrm{in.} \\ \text { Pin geometry } & \text { Triangular Pitch, } \\ & \text { Spiral Spacers } \\ \text { Spacer O. D. } & 0.090 \text { in. } \\ \text { Pin clad material } & \text { Stainless Steel }\end{array}$

1. Helium Requirements With Shroud Around Specimen

Sketch SKC-2895 (Figure I-6) shows a possible arrangement for cooling the specimen with helium when the shroud is around the specimen. This sketch shows a hose connection feeding helium into the specimen but no hose on the outlet. It has been assumed that the loop feeding the specimen is open to the hot cell. The cooling requirements for a closed loop would be the same as for an open loop.

The helium requirements were calculated by first assuming the specimen to be divided into 6 inch increments. The maximum temperature was calculated for each section by performing a heat balance on the section for several assumed helium flows and an assumed heat load. The helium flow was thus found that results in a maximum specimen surface temperature of $1000 \mathrm{~F}$. A $100^{\circ} \mathrm{F}$ safety factor was included in the flow determination in order to provide a factor of safety for the inaccuracies involved in the calculations, for the assumption of a constant radial heat distribution, and for the assumption of an average flow distribution in the specimen.

The previous calculations were repeated for several other assumed heat loads. Figure I-2 shows the resulting heat load versus helium flow required to maintain a $1000 \mathrm{~F}$ specimen surface temperature. By using Figure I-2 in conjunction with the specimen decay heat curve (shown in Appendix A) the helium requirements versus time were determined. Figure I-3 shows the helium requirements for specimen irradiation times of 10,000 hours and 2,000 hours. In developing Figure I- 3 from the decay heat curve and from Figure I-2, a $25 \%$ safety factor was applied to the actual specimen fission power of $1,500 \mathrm{kw}$.

Figure I-2 also contains a curve showing helium pressure drop for the specimen with the shroud in place. The analysis for this curve

* Contained in letter dated April 4, 1962, from H. M. Leppich to R. H. Gordon. 
considers the total specimen pressure drop to consist of fuel pin pressure drop and drag losses due to the spiral wound spacers. The fuel pin pressure drop was calculated by the standard Darcy formula. The spacer loss was based on a formula presented in the June 1961 is sue of "Nucleonics"。*

\section{Helium Requirements With No Shroud Around Specimen}

Sketch SKC-2912 (Figure I-7) shows a possible arrangement for cooling the specimen with helium when no shroud surrounds the specimen. The helium requirements for this arrangement were e stimated from work performed at Argonne National Laboratory (ANL) and reported in the December 1956 is sue of "Nucleonics".**

This article contains the results of an experimental program that was conducted with an electrically heated fuel bundle with 91 pins in which a gas was first blown across the bundle in a manner similar to that in SKC-2912 and then was blown longitudinally through the bundle in a manner similar to SKC-2895. The results show that the maximum fuel rod surface temperature for the case with longitudinal flow was approximately the same as for the case with the flow across the bundle when the gas flow and heat loads were approximately the same.

Relating this work to the specimen of concern in this design data sheet indicates that approximately the same helium flow would be required with the shroud off as is required with the shroud on. This should be a conservative analogy since only 7 pins are in volved in this specimen as compared to 91 pins in the ANL specimen.

The ANL experimental work can also be used to give an indication of the pressure drop that can be expected with flow across the bundle. In the experimental work a full scale assembly of a 91 pin specimen was used to determine the pressure drop due to a gas flowing across the fuel pins. It was found that less than 2 inches of water pressure drop occurred when $14 \mathrm{scfm}$ of air was passed across the bundle. From attached Figure I-3 the helium flow required at a decay time of one day is $220 \mathrm{cfm}$. **** Correcting the 2 inches of water from the ANL work for $220 \mathrm{cfm}$ of helium instead of $14 \mathrm{scfm}$ of air gives a pressure drop of 37 inches of water. It would be reasonable to expect that a pressure of 37 inches would be more than sufficient to force the required $220 \mathrm{cfm}$ through the specimen holder and across the specimen since the specimen of this design data sheet contains 7 pins compared to 91 pins in the ANL work. Title I work will verify this.

* "Drag Coefficients for Fuel Element Spacers," A.N. de Stordeur, BelgoNucleaire S.A., Brussels, Belgium, June 1961, "Nucleonics."

*** "Decay Heat Cooling Requirements of Spent Fuel From EBR-2," by C. H. Srheihe1hut. Argonne National Laboratorr. December 1956. "Nucleonics."

$* * *$ Density $=0.005 \mathrm{lb} / \mathrm{ft}^{3}$ 
3. Rate of Temperature Rise With No Forced Cooling

The ANL experimental work discussed in the previous section indicates that when the pins are separated from the bundle no forced cooling is necessary. Since the specimen of this design data sheet has a higher heat flux than the ANL specimen, then it will require an analysis in Title I to determine if this holds true for this specimen.

An analysis was performed to determine the rate of temperature rise in the specimen as a function of decay time with the specimen as sembled and with no forced cooling. For this analysis it was assumed that the specimen was in an adiabatic condition; that is, all decay heat was considered to go toward raising the specimen temperature. Figure I-4 is a set of curves showing the results of the se calculations.

4. Maximum Specimen Decay Heat Flux

Figure $I-5$ is a curve of maximum specimen heat flux versus time and is presented for general information. This curve was developed by using the decay heat curve (Appendix A) and a maximum hot spot heat output of $9 \mathrm{kw} /$ inch which is specified in the Design Objectives.*

\section{Results and Conclusions}

The analyses in many cases were based on as sumed conditions to aid in establishing handling procedures. It is almost certain that the conditions corresponding to actual handling procedures will be different. How ever, the results presented can be used as a guide.

Since consideration is being given to using argon in the inert atmosphere hot cell, a rough comparison of the cooling requirements for argon and helium indicates:

(1) The weight flow of argon would be approximately twenty (20) times the required helium flow.

(2) The volume flow of argon would be approximately two (2) times the required volume flow of helium.

(3) The pressure drop for argon would be approximately twenty (20) times that of helium.

The amount of helium required to cool the specimen is shown in Figure I-3. To use this curve, enter the horizontal axis with the decay time, rise vertically to the specimen irradiation time and then project the point horizontally to the vertical axis where the required helium flow can be read. The curve shows that after one day of decay, for 10,000 hours irradiation time, the required helium is $220 \mathrm{cfm}$. The helium requirements decrease

* Contained in letter dated April 4, 1962 from H.M. Leppich to R.H. Gordon. 
rapidly to approximately $84 \mathrm{cfm}$ at 7 days decay time. After 7 days decay time the helium requirements decrease slowly with $26 \mathrm{cfm}$ required at 30 days.

Once the required helium flow is found as described above, the heat load and specimen pressure drop corresponding to this flow can be found. This is done by entering the horizontal axis of Figure I-2 with the helium flow and then projecting the point up to the proper curve to read either the heat load or specimen pressure drop on the vertical axis. The specimen pressure drop can be used in sizing the helium pumping system and the heat load can be used in sizing the system that is used to cool the helium. With no forced cooling the specimen temperature rises rapidly when the fuel pins are in a bundle. For example, entering Figure I-4 at a decay time of one month gives a temperature rise of $117 \mathrm{~F} / \mathrm{min}$ for an irradiation time of 10,000 hours. Thus, if the specimen were cooled to approximately $300 \mathrm{~F}$ before forced cooling was stopped, then in approximately 6 minutes the specimen would be at the maximum allowable surface temperature of $1,000 \mathrm{~F}$. This means that very little time is available for work requiring no forced cooling when the fuel pins are in a bundle.

\section{Title I Work}

The results of this investigation should not be taken as final. Rather, this is intended to be used as a guide in directing Title I work in specimen handling. This work would consist of a more thorough study of forced cooling of the specimen, utilizing a digital computer to solve the most complex parts of the problem. Experimental work might be required to gain a more accurate picture of specimen cooling by natural convection when the specimen is assembled and disassembled. Any studies of specimen handling in Title I would be performed based on a decay heat curve for a plutonium-uranium specimen. Since this curve is not presently available, it would have to be developed in Title I.

A more detailed analysis, with possible experimental work, may be required in Title I to obtain more accurate values of specimen pressure drop for the cases of both longitudinal and cross flow. This would be necessary in order to accurately size the helium supply system. It may be more advantageous, however, to over-size the helium pumping system and to specify helium flows for different decay periods that would give conservative results. 


\section{APPENDIX A}

\section{ATR THERMAL LOOP SPECIMEN HEAT FLUX AFTER IRRADIATION}

At any time after normal in-pile loop operation, the heating of the individual fuel elements caused by decay heat from fission products must be limited to prevent post-irradiation changes in the metallurgical properties of the fuel. Heat is produced in natural uranium after reactor shutdown by the following methods: (1) fissions from delayed neutrons, (2) decay of radioactive fission products, and (3) decay of U-239 and Np-239. Since item (1) becomes insignificant within a few minutes after shutdown, the last two items are the only ones considered. A typical fission product decay curve for natural uranium was used as the basis for calculating the maximum specimen heat flux during the fission product decay period after irradiation. Figure I-8 is a curve of total decay power versus cooling time and is based on results from Untermyer and Weills.* This curve includes the effect of U-239 and $\mathrm{Np}-239$. The decay power will be studied in detail in Title $I$.

* Untermyer and Weills, Table 33. "Decay Heat Rate of Fission Products," H. Etherington, Ed., Nuclear Engineering Handbook, p. 1-39, McGraw-Hill Book Co., Inc., 1958. 


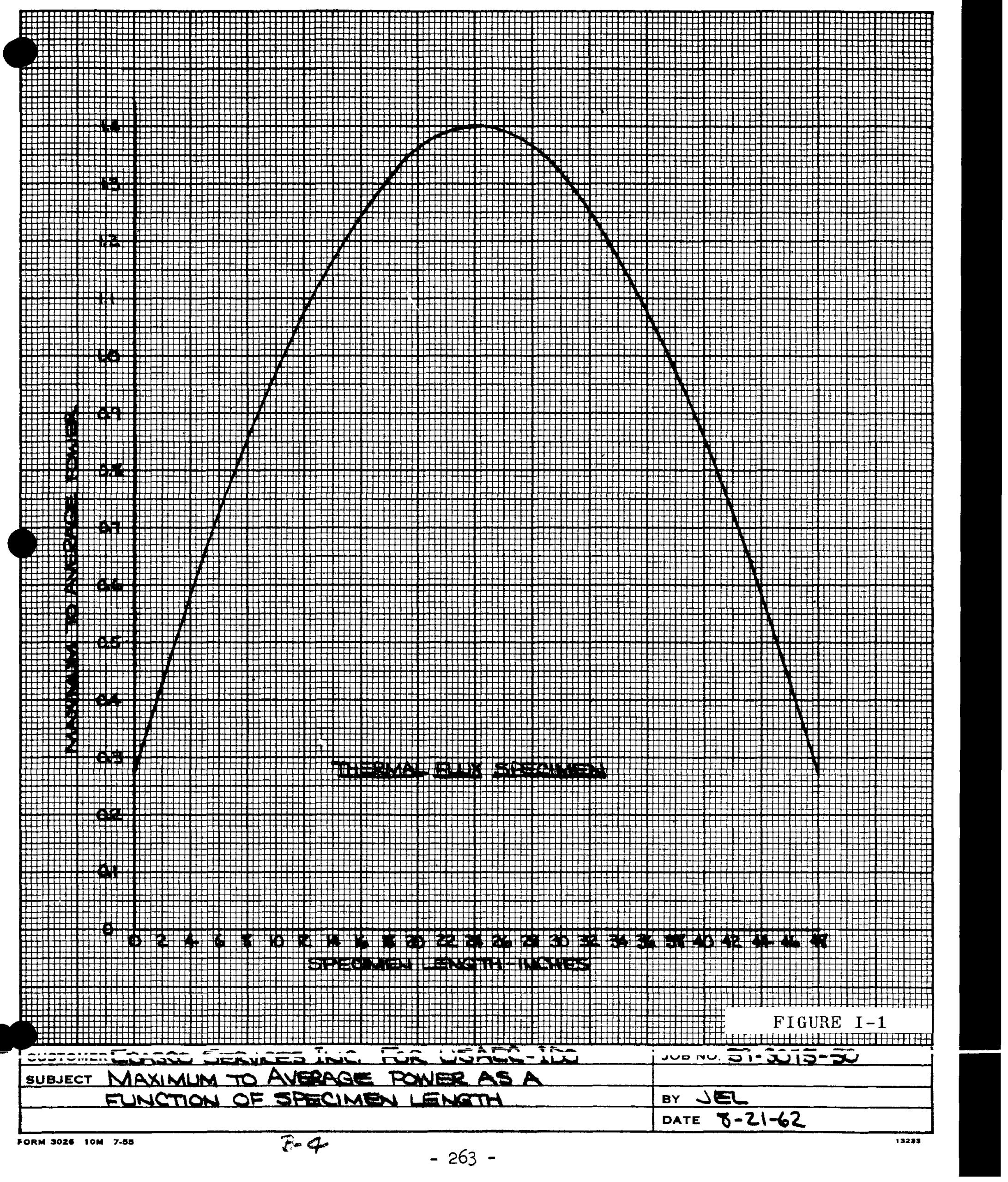




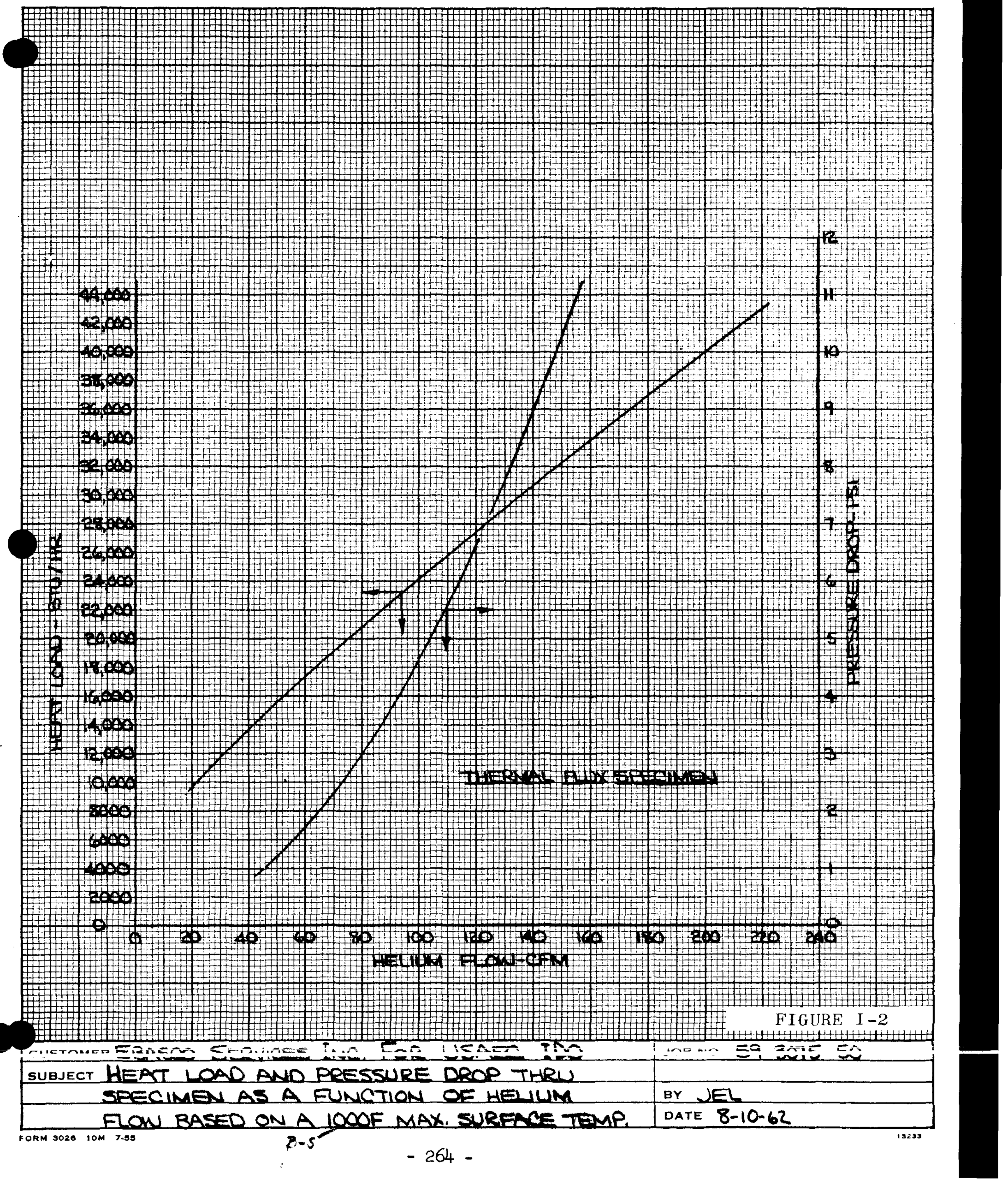




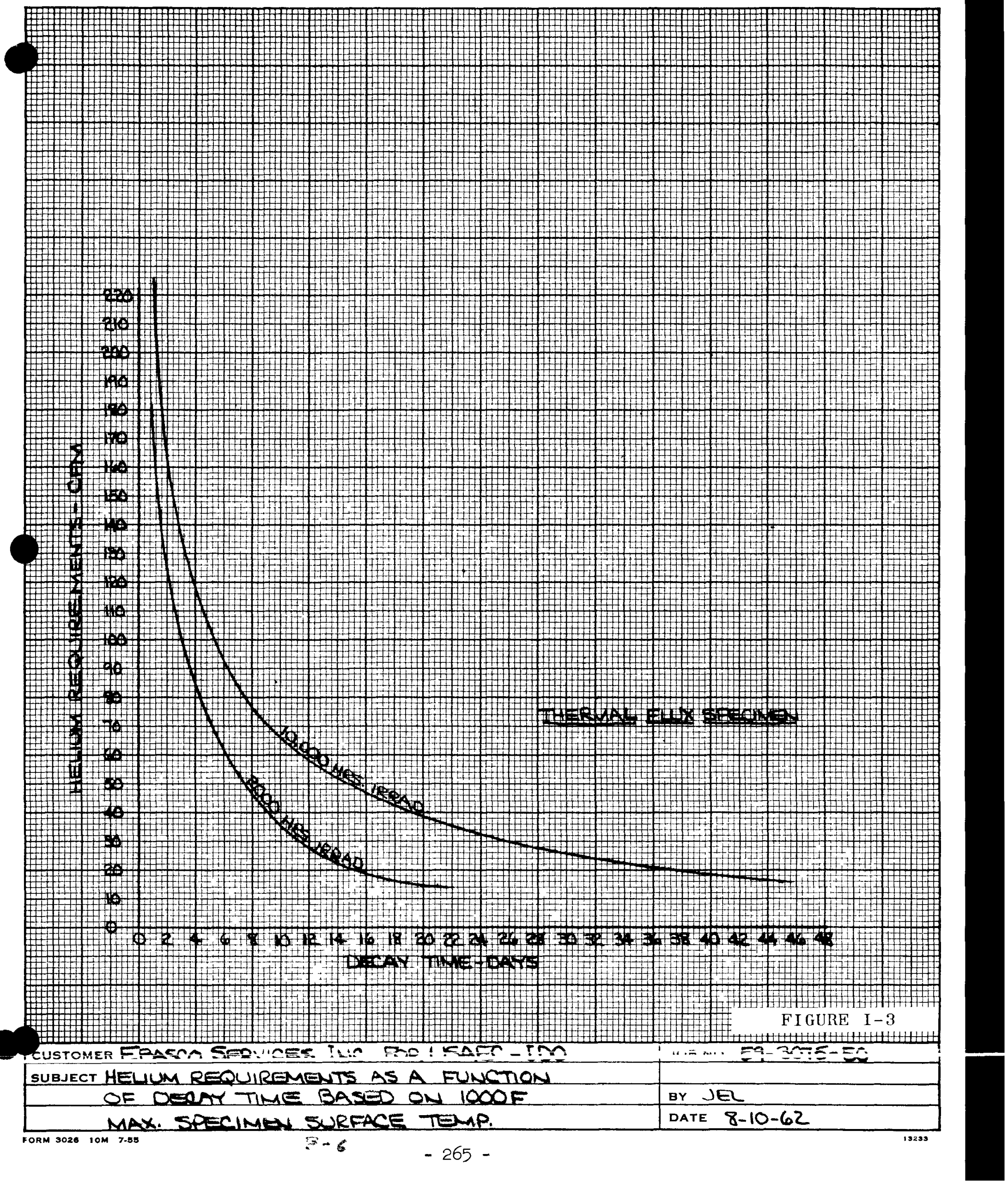




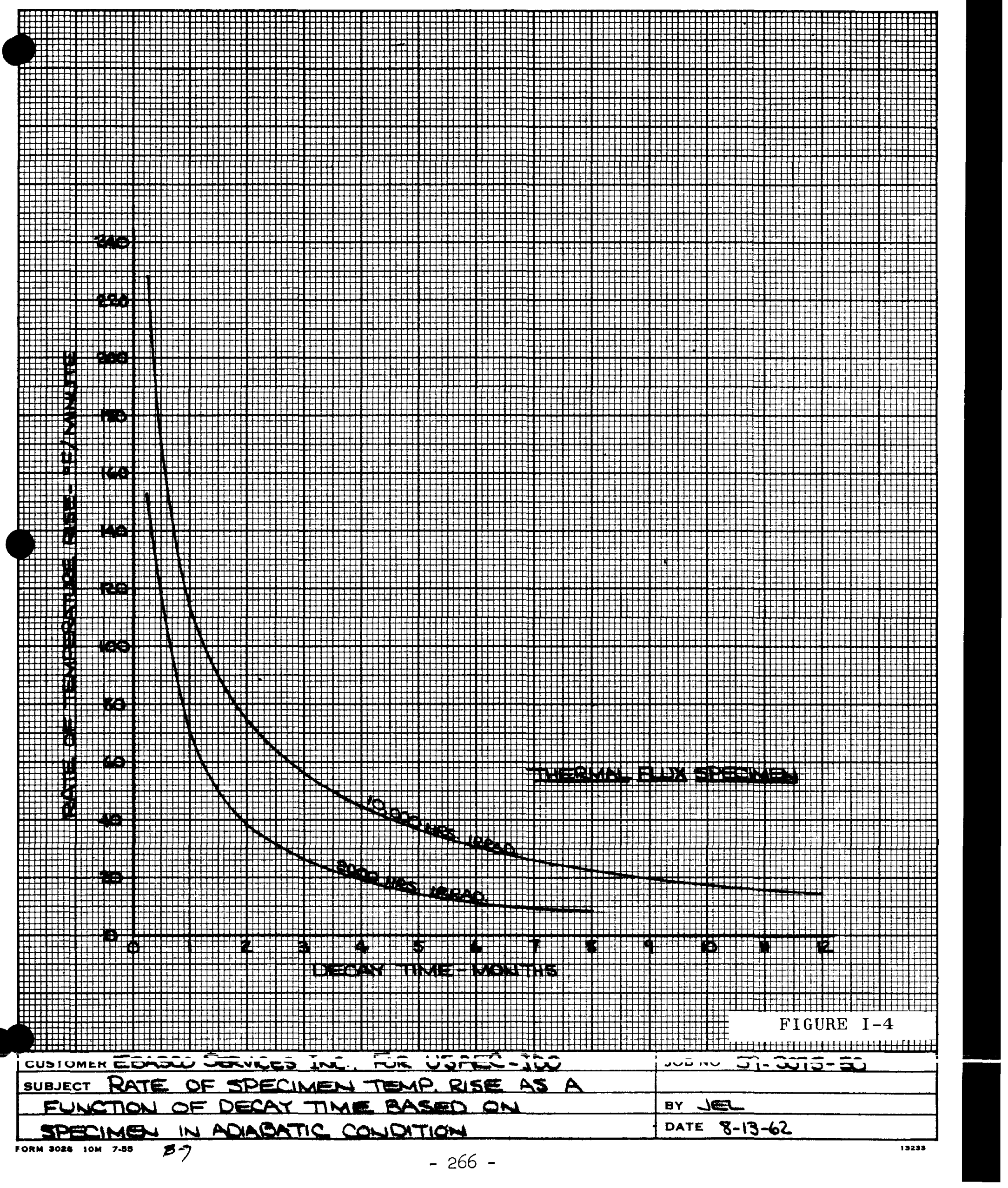




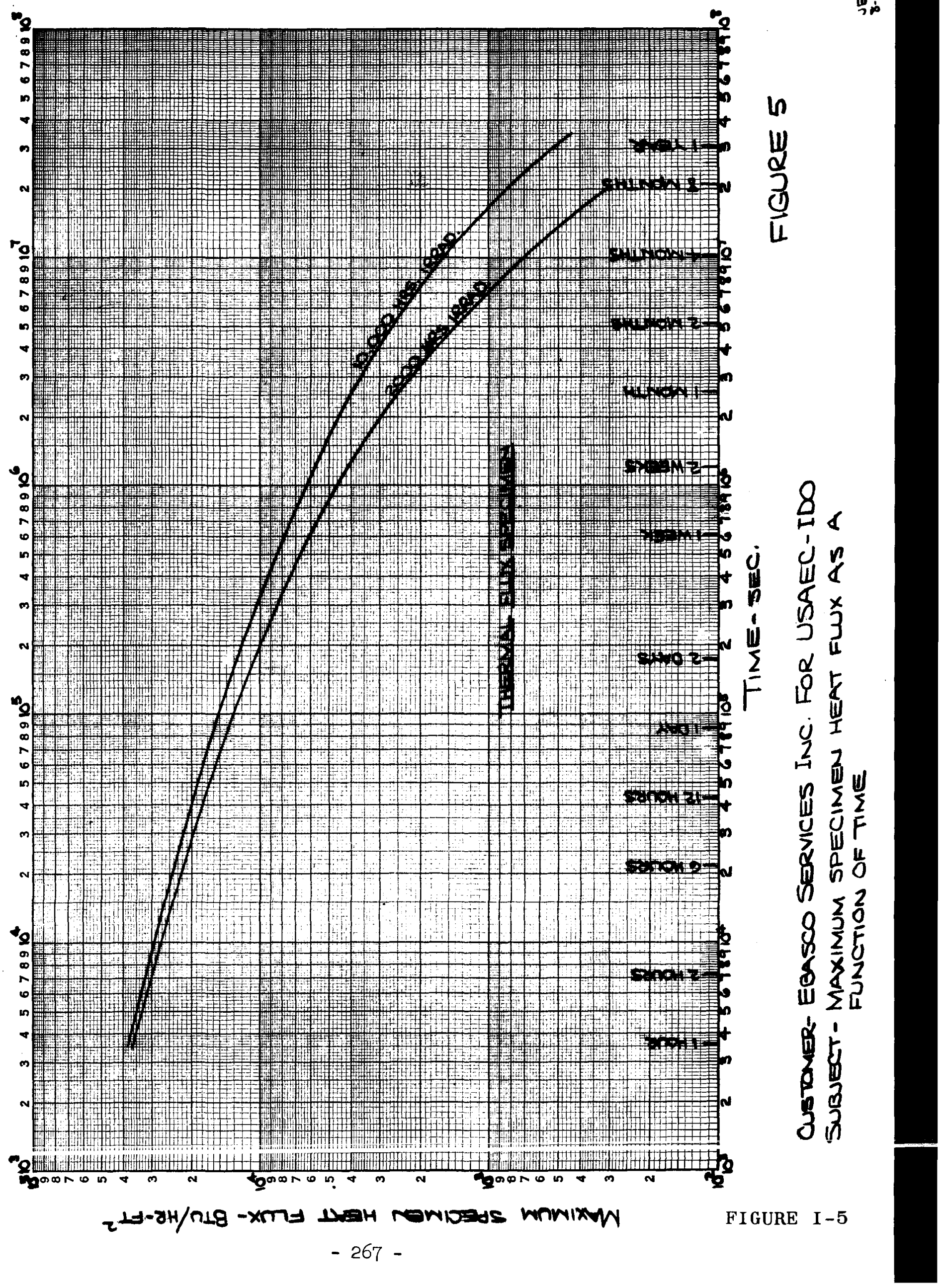




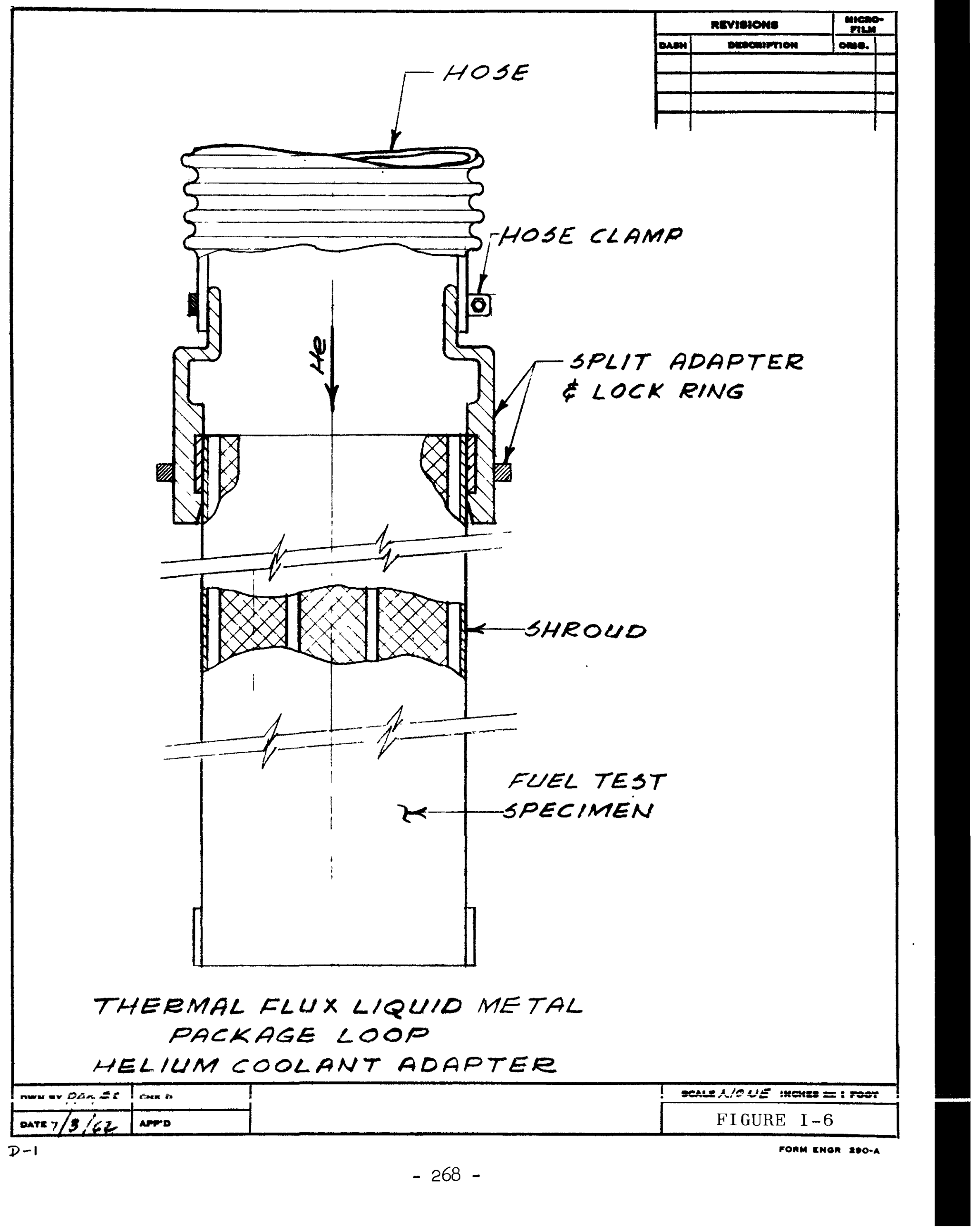




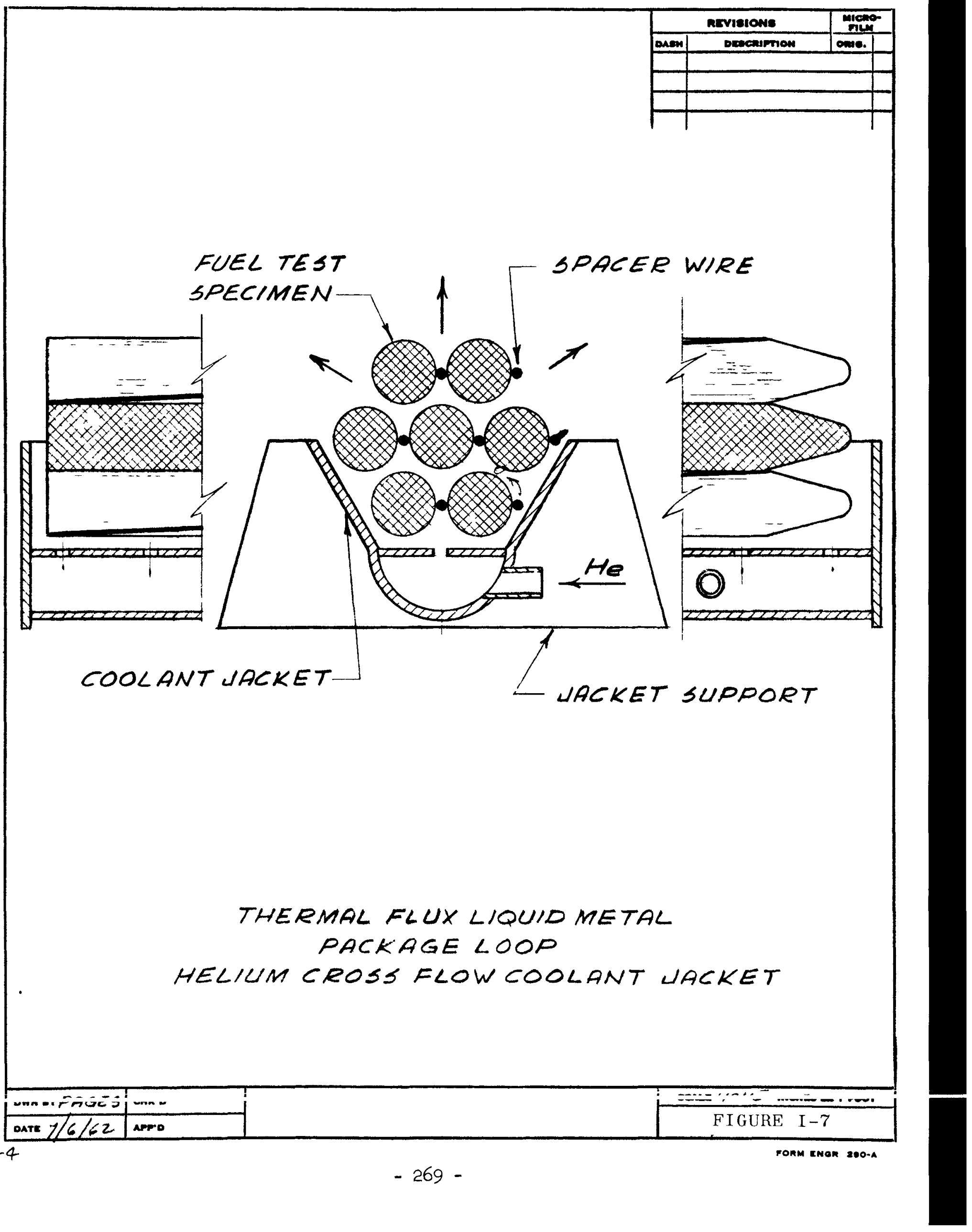




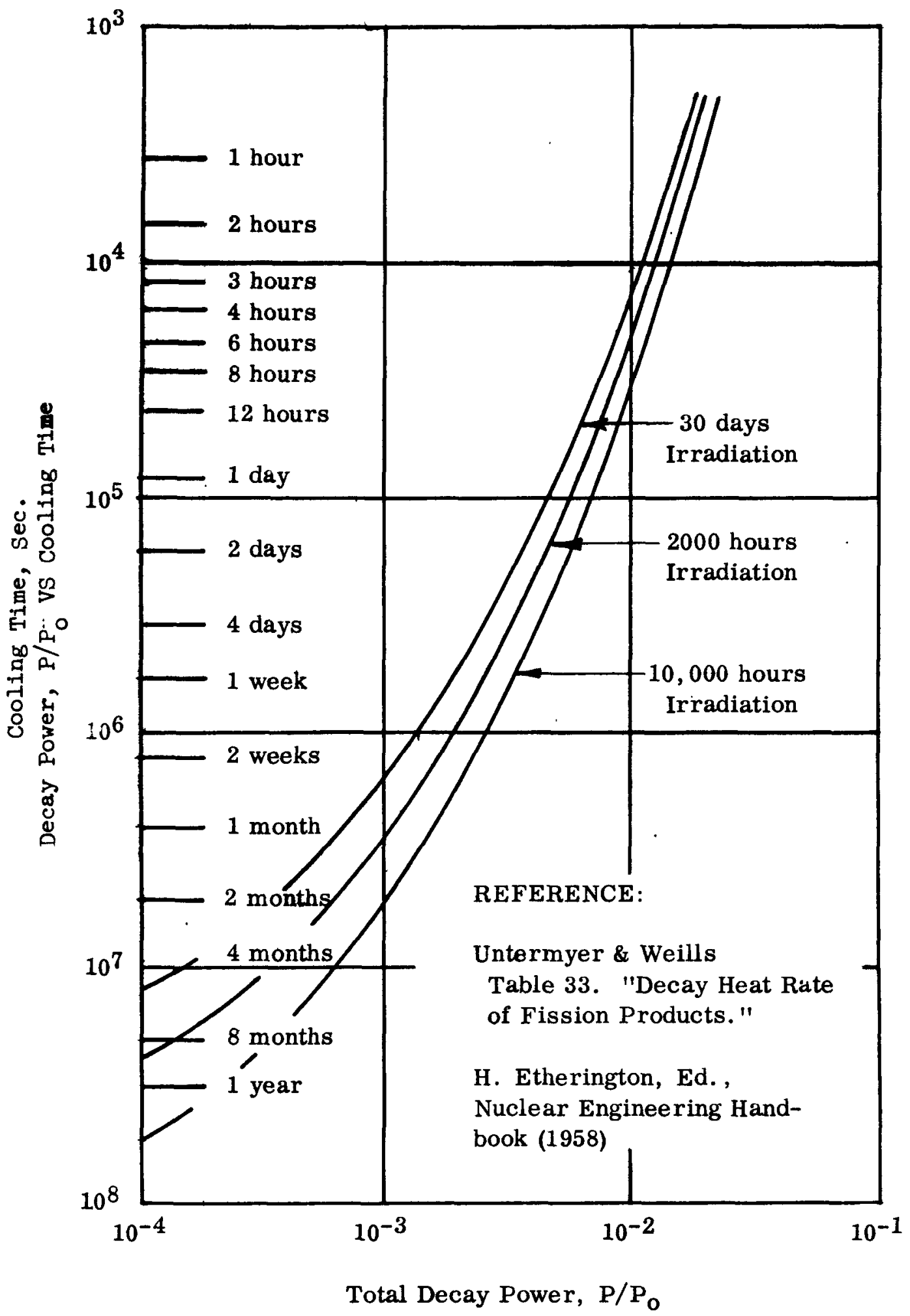

FI GURE I -8 


\section{APPENDIX J}

Hot Cell Shielding Requirements for Package Loops Handling Operations and Storage 
Design Data Sheet R-6003

59-3075-50

Contract No. AT $(10-1)-1075$

May 18, 1962

D. R. Whitaker

\author{
THE BABCOCK AND WILCOX COMPANY \\ FOR EBASCO SERVICES INC. \\ DESIGN DATA \\ ADVANCED TEST REACTOR \\ HOT CELL SHIELDING REQUIREMENTS FOR \\ PACKAGE LOOPS HANDLING OPERATIONS \& STORAGE
}

\title{
PURPOSE AND SCOPE
}

To determine the thicknesses of concrete shielding required for the ATR hot cell facility for handling and storing liquid metal package loops.

\section{GENERAL DESCRIPTION}

Table I lists the after shutdown dose rates from fission products in the fast flux and thermal flux liquid metal package loops stored in the ATR hot cell facility. These dose rates are based on two fast loops and two thermal loops all containing fuel specimens that have been irradiated for 10,000 hours and are quoted at 1 foot from the outside surface of the hot cell wall. Table I results are based on varying thicknesses of ordinary concrete, and Figure J-1 shows a curve of fission product dose rate versus ordinary concrete thickness for the hot cell facility.

Table II lists the after shutdown dose rates from the same sources of radiation using the same assumptions as for Table I. These dose rates, however, are based on magnetite concrete instead of ordinary concrete. Figure $\mathrm{J}-2$ shows a curve of fission product dose rate versus magnetite concrete thickness for the hot cell facility.

The fission products are assumed to be retained in the fuel pins and are based on fast loop specimen power of $150 \mathrm{kw}$ and thermal loop specimen power of $1500 \mathrm{kw}$. 


\section{TABLE I}

Gamma Dose Rates Outside ATR Hot Cell Facility With Ordinary Concrete Walls

Fission Product Source

$\frac{\text { Gamma Dose Rate }(\mathrm{mrem} / \mathrm{hr})}{\text { After Shutdown Time }}$

12 Hours 17 Days 100 Days

Ordinary Concrete Thickness $(2.35 \mathrm{~g} / \mathrm{cc})$

$\underline{2 \text { Feet }} \underline{5 \text { Feet }} \quad \underline{2 \text { Feet }} \quad \underline{5 \text { Feet }} \quad \underline{2 \text { Feet }} \underline{5 \text { Feet }}$

Thermal Flux

Loops (2)

$9.40 \times 10^{5}$

$2.89 \times 10^{1}$

$2.67 \times 10^{5}$

$6.37 \times 10^{0}$

$1.77 \times 10^{4}$

$4.63 \times 10^{-1}$

Fast Flux

Loops (2)

$\underline{2.25 \times 10^{5}} \quad \underline{7.63 \times 10^{0}}$

$6.80 \times 10^{4}$

$\underline{2.25 \times 10^{0}} \quad \underline{1.29 \times 10^{4}} \quad 1.91 \times 10^{-1}$

Total

$1.65 \times 10^{6}$

$3.653 \times 10^{1}$

$3.35 \times 10^{5}$

$8.62 \times 10^{0} 3.06 \times 10^{4}$

$6.54 \times 10^{-1}$

\section{TABLE II}

Gamma Dose Rates Outside ATR Hot Cell Facility With Magnetite Concrete Walls

Fission Product

Source

\section{Gamma Dose Rate (mrem/hr) \\ After Shutdown Time}

12 Hours 17 Days 100 Days

Magnetite Concrete Thickness $(3.55 \mathrm{~g} / \mathrm{cc}$ )

$$
2 \text { Feet } 5 \text { Feet } 2 \text { Feet } 5 \text { Feet } 2 \text { Feet } 5 \text { Feet }
$$

Thermal Flux

Loops (2)

$3.36 \times 10^{4}$

$2.59 \times 10^{-2}$

$9.24 \times 10^{3}$

$4.32 \times 10^{-3} 2.45 \times 10^{2}$

$5.34 \times 10^{-4}$

Fast Flux

Loops (2)

Total

$9.95 \times 10^{3}$

$6.48 \times 10^{-3}$

$2.84 \times 10^{3}$

$4.355 \times 10^{4}$

$3.24 \times 10^{-2}$

$1.21 \times 10^{4}$

$6.15 \times 10^{-3} 5.87 \times 10^{2}$

$1.89 \times 10^{-4}$

$7.23 \times 10^{-4}$ 


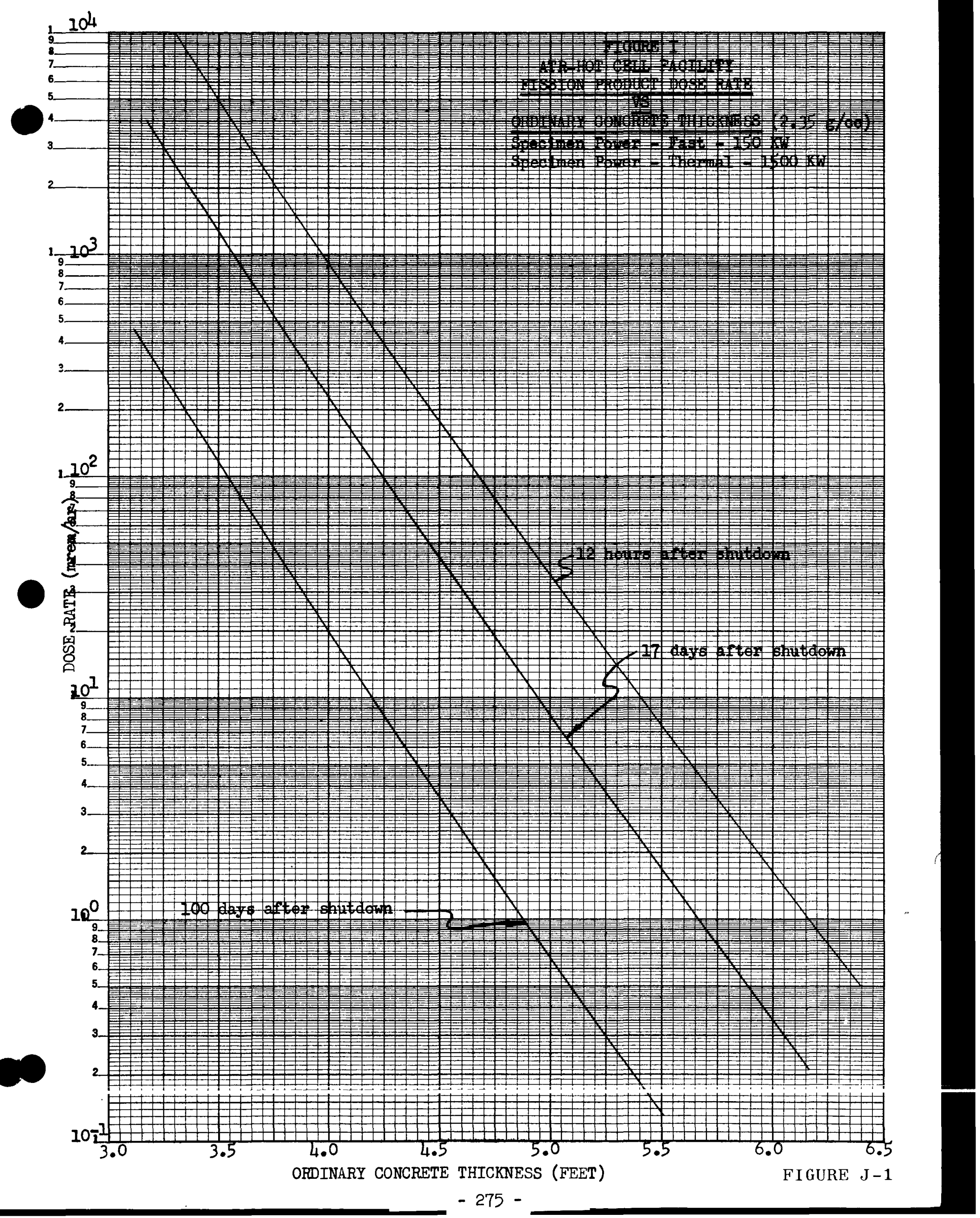




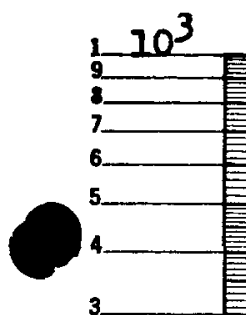

$+1$

L 3.

3 atar

2

$10^{2}$

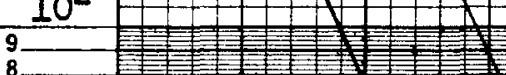

$8 \longrightarrow \ldots \geq \geq$<smiles>C1=C2C[C]1C2</smiles>

$$
\begin{array}{l|l}
7 & \\
\end{array}
$$

4

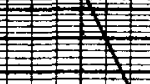

3.

2

$1.10^{1}$

द⿱乛龰

$+$

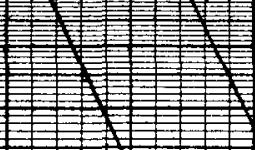

於

$\mathrm{E}^{4}$

舅

窟,

용

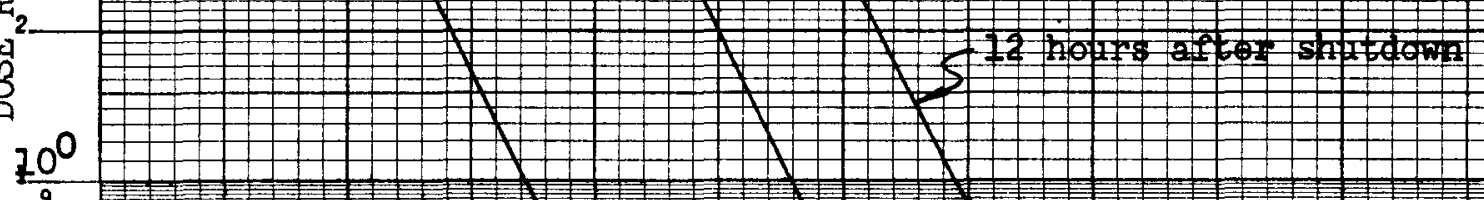

$70^{\circ}$

7

6. II

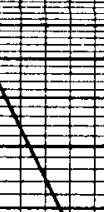

4

2

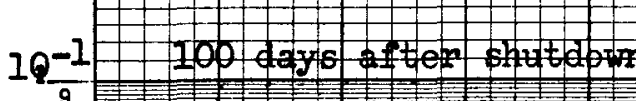

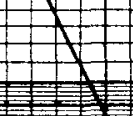

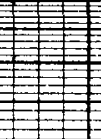
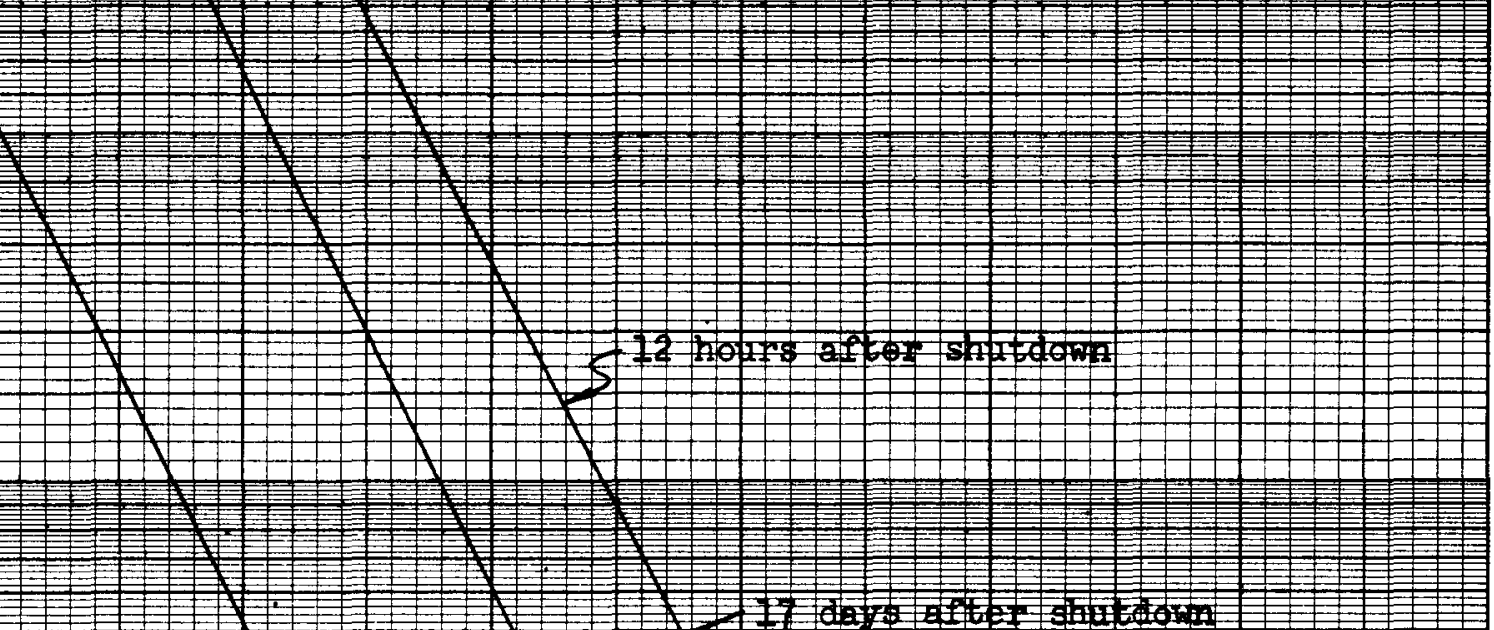

77 staterar
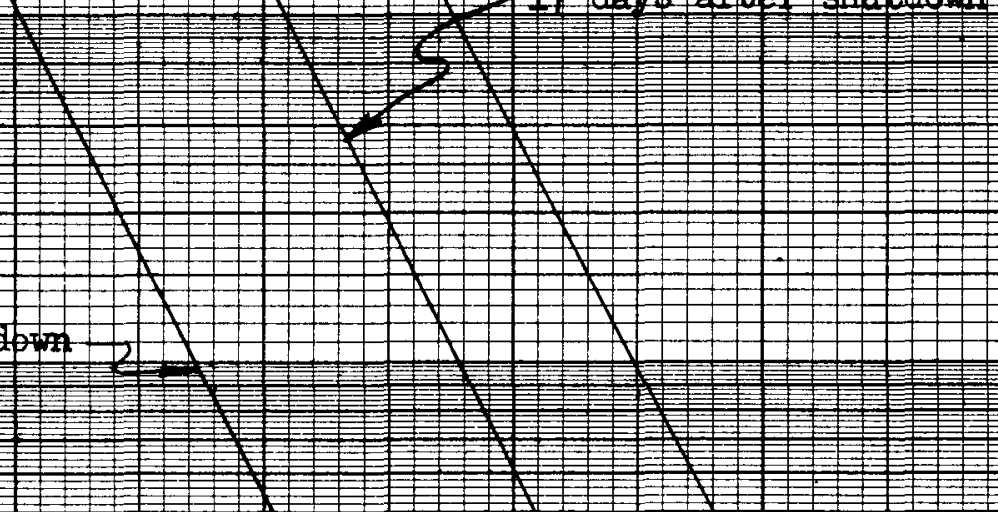

1

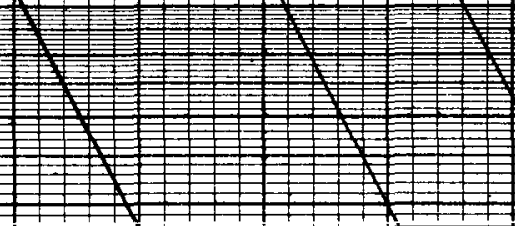

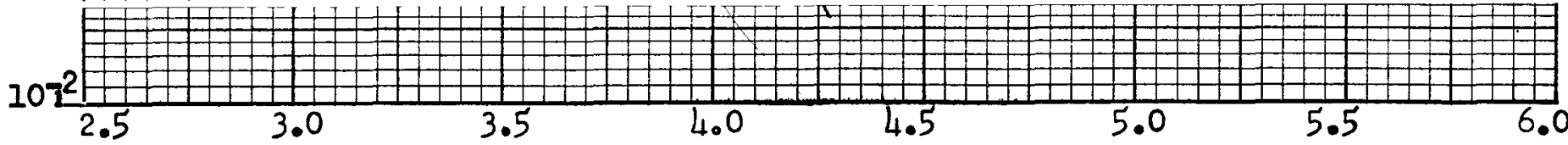
MAGNETITE CONCRETE THICKNESS (FEET) 
APPENDIX K

Fast Flux Liquid Metal Package

Loop Radiation Dose Rates 
0

0 


\section{THE BABCOCK \& WILCOX COMPANY FOR EBASCO SERVICES. INC. DESIGN DATA ADVANCED TEST REACTOR FAST FLUX LIQUID METAL PACKAGE LOOP RADIATION DOSE RATES}

\section{Purpose and Scope}

To determine the gamma dose rates above the fast flux loop during loop handling and transfer operations.

Two situations are considered: (1) The case in which the test specimen has not ruptured and the specimen fission products are retained in the specimen, and (2) The case in which the test specimen has ruptured and fission products are released into the primary coolant NaK stream.

\section{General Description}

In all cases, the datum from which water thicknesses are measured is the top of the loop.

Although this data sheet is directed primarily at in-reactor handling of the locp, the information presented can also be used in considering handling problems with the loop in the canal during transfer to and from the hot cell.

\section{Case I - Unruptured Fuel Pins}

Table I lists the dose rates at one (1) hour after shutdown from all the major sources of after shutdown radiation for several thicknesses of water shielding above the top of the fast flux loop. The dose rates are for the unruptured fuel pin case, i.e., fission products retained in the fuel specimen. As can be seen in the table, the liquid metal (NaK) activation and fission product dose rates are the major contributors to the dose rates while the loop structural materials activation and fast activation are negligible. The NaK activation is more important than the fission products because the NaK is distributed throughout the loop with the maximum elevation being the NaK sump, approximately six (6) feet above the top of the test specimen.

The calculations are based on an irradiation time of 10,000 hours for fission product source calculations and all activation problems. Specimen power was assumed to be $150 \mathrm{KW}$. 
The fission product dose rates and dose rates from fast and thermal activation of structural steel were computed by assuming a point source geometry at the top of the test specimen. The liquid metal activation, however, was computed by assuming line sources of NaK distributed in the sump, heat exchanger, and in-core portion of the loop. Point isotropic dose buildup factors for water were used for all calculations.

\section{TAB LE I}

\section{AFTER SHUTDOWN DOSE RATES IN ATR FAST FLUX LOOP* (1 Hour After Shutdown) Un-Ruptured Fuel Pins}

\begin{tabular}{|c|c|c|c|}
\hline \multirow[b]{2}{*}{ Radiation Source } & \multicolumn{3}{|c|}{ Water Thickness Over Top of Loop } \\
\hline & -1 Foot & 1 Foot & 3.5 Feet \\
\hline Fission Products & $3.00 \times 10^{2}$ & $1.45 \times 10^{1}$ & $3.80 \times 10^{-1}$ \\
\hline NaK Activation & $1.70 \times 10^{3}$ & $8.74 \times 10^{1}$ & $2.52 \times 10^{0}$ \\
\hline Fast Activation & $1.14 \times 10^{0}$ & $2.79 \times 10^{-2}$ & $3.85 \times 10^{-4}$ \\
\hline Structural Materials Activation & $3.16 \times 10^{-1}$ & $1.27 \times 10^{-2}$ & $2.52 \times 10^{-4}$ \\
\hline Total & $2.00 \times 10^{3}$ & $1.02 \times 10^{2}$ & $2.90 \times 10^{0}$ \\
\hline
\end{tabular}

*Dose rates with no credit taken for vessel top head or shield plate attenuation.

The top of the fast loop is approximately nine (9) feet above the top of the core when the loop is in its normal operating position. When the loop is raised to its uppermost position during loop replacement, the top of the loop is about one foot above the water level in the reactor (elevation 100 feet). Since the dose rate at the water surface with minus one $(-1)$ foot of water is well above tolerance as shown in Table I, shielding of some type must be provided. With the eight (8) inch steel shield plate in place atop the reactor and all loop holes plugged, the dose rates shown in Table I and Fig. K-l will be decreased by a factor of at least 200. Streaming between the loop walls and the penetration in the shield plate presents a problem which probably can be best solved by installation of temporary shielding. A lead plug shield (approximately 15 inches thick) in the top of the loop is located so as to attenuate radiation streaming vertically upward from the loop sources through the loop penetration in the vessel head. This plug is designed to reduce direct streaming to less than $0.25 \mathrm{mrem} / \mathrm{hr}$ when the loop is in its uppermost position.

If penetrations through the lead are necessary for helium lines, electrical connections, etc., additional shielding must be provided to compensate for this. Vertical straight-through passages should not be placed in the lead 
and necessary penetrations should be minimized in size and number.

The penetration and streaming problems will be detailed in Title I studies and the top shield plug will be designed at that time.

Figure K-1 shows the calculated dose rates at the water surface versus thickness of water over the top of the fast flux loop for various shutdown times. The effect of steel and lead plug shielding is not included.

Case II - Ruptured Fuel Pins

Table 2 lists dose rates at one (1) hour after shutdown from all the major sources of after shutdown radiation for several thicknesses of water shielding. Water thickness is again shown as total height above the top of the fast flux loop. As can be seen in the table, the fission product dose rates are the major contributor to the total dose rates. Liquid metal activation is a relatively minor contributor to the dose rates, while the loop structural materials activation and fast activation are negligible. The fission product dose rates are for the worst case, i.e., ruptured fuel pins with fission products distributed in the loop primary coolant (NaK). Only part of the fission products were assumed to leak out of the fuel pins - $100 \%$ of the gases, $10 \%$ of the halides and $1 \%$ of the solids. These were considered to be concentrated in the $\mathrm{NaK}$ sump. It should be noted that with the fission products concentrated in the NaK sump, the fission product sources are nearest to the dose point, (i.e., the least possible shielding is between the radiation source and the dose point location).

The calculations are again based on an irradiation time of 10,000 hours for the fission product formation and all activation problems, and on a specimen power of $150 \mathrm{KW}$.

The fission product dose rates and liquid metal activation were computed using a geometry of a series of line sources of radiation. The fission products were assumed to be concentrated in the NaK sump. The NaK was assumed to be in the sump, heat exchanger, and in-core portion of the loop for $\mathrm{NaK}$ activation calculations. Fast and thermal activations of structural steel were computed by using a point source geometry at the top of the test specimen. Point isotropic dose buildup factors for water were used for all the calculations.

TABLE 2

AFTER SHU TDOWN DOSE RATES IN ATR FAST FLUX LOOP*

(1 Hour After Shutdown)

Ruptured Fuel Pins

\begin{tabular}{|c|c|c|c|}
\hline \multirow[b]{2}{*}{ Radiation Source } & \multicolumn{3}{|c|}{ Gamma Dose Rates (mrem/hr) } \\
\hline & -1 Foot & 1 Foot & 3.5 Feet \\
\hline Fission Products & $2.59 \times 10^{5}$ & $1 . \overline{0.0 \times 10^{4}}$ & $1.62 \times 10^{2}$ \\
\hline $\mathrm{NaK}$ Activation & $1.70 \times 10^{3}$ & $8.74 \times 10^{1}$ & $2.52 \times 10^{0}$ \\
\hline Fast Activation & $1.14 \times 10^{0}$ & $2.79 \times 10^{-2}$ & $3.85 \times 10^{-4}$ \\
\hline Structural Materials Activation & $3.16 \times 10^{-1}$ & $1.27 \times 10^{-2}$ & $2.52 \times 10^{-4}$ \\
\hline Total & $2.61 \times 10^{5}$ & $\overline{1.01 \times 10^{4}}$ & $1.65 \times 10^{2}$ \\
\hline
\end{tabular}

*Dose rates with no credit taken for vessel head or shield plate attenuation. 
In this case, when the loop is in its uppermost position, even the shield plate attenuation factor of 200 does not reduce to tolerable levels the radiation dose rates atop the reactor. Therefore, additional shielding must be provided when this assumed case becomes reality.

The 15 inch lead plug in the top of the loop attenuates radiation streaming vertically upward to $0.25 \mathrm{mrem} / \mathrm{hr}$ at the top of the loop.

Figure K-2 shows the calculated dose rates at the water surface versus thickness of water over the top of the fast flux loop for various shutdowntimes. The effect of steel and lead plug shielding is not included.

Design Criteria

Table 3 shows the shielding design criteria for various areas in the ATR facility. They are taken from S-R-88 "Interim Shielding Design Report for the Advanced Test Reactor," September, 1961. 


\section{ATR SHIELD DESIGN DOSE RATE CRITERIA}

\section{Location}

Full-time occupancy areas

Outside reactor concrete shielding

Outside experiment loop cubicles Inside experiment $\mathrm{H}_{2} \mathrm{O}$ loop
cubicles

Motor area

Sub-pile room

Rod access room

Above storage canal and at floor level near parapet

Outside demineralizer vaults

Inside demineralizer vaults

Floor above heat exchangers

Inside sample areas

Maximum transient dose rate during refueling

Reactor area - 1st floor

Reactor vessel top head
Design Level During Full Power Operation

0.25

2.5

2.5

2.5 from adjacent operating cubicle; 50 from reactor and primary piping

$$
1.0
$$

No access

7.5

1.0

7.5

No access

1.0

7.5 total from reactor, cubicles, and fuel in storage canal; 25 from sample
Design Level $\frac{\text { After Shutdown }}{(\mathrm{mrem} / \mathrm{hr})}$

0.25

2.5

2.5

5.0 (Loops not operating)

1.0

12.5 one hour after shutdown

2.5

1.0

7.5

7.5 from adjacent vault after flushing resin in vault

1.0

7.5

50.0

1.0

1.0

2.5
1.0 from core with head removed after flushing 


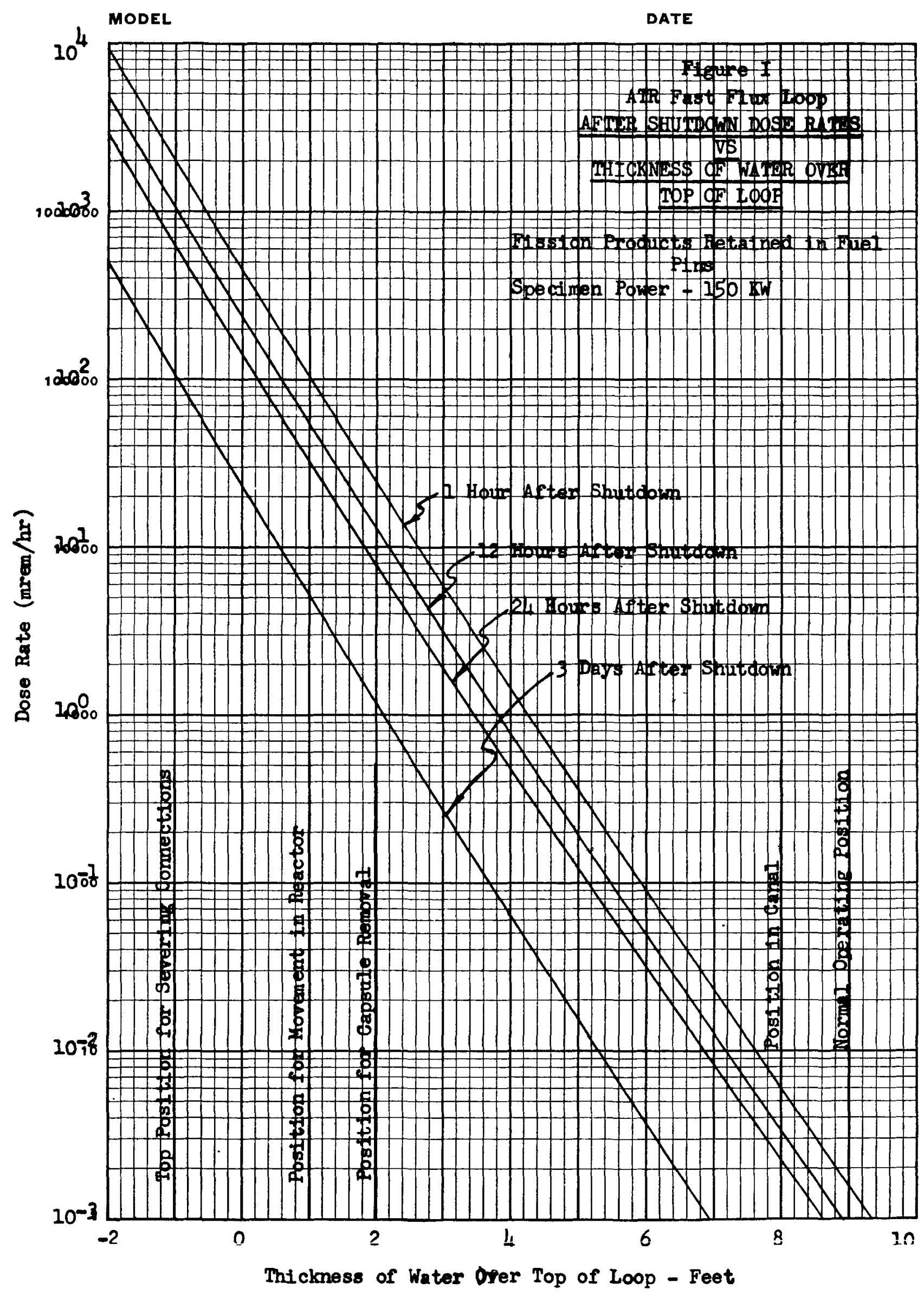

F I GURE K-1 


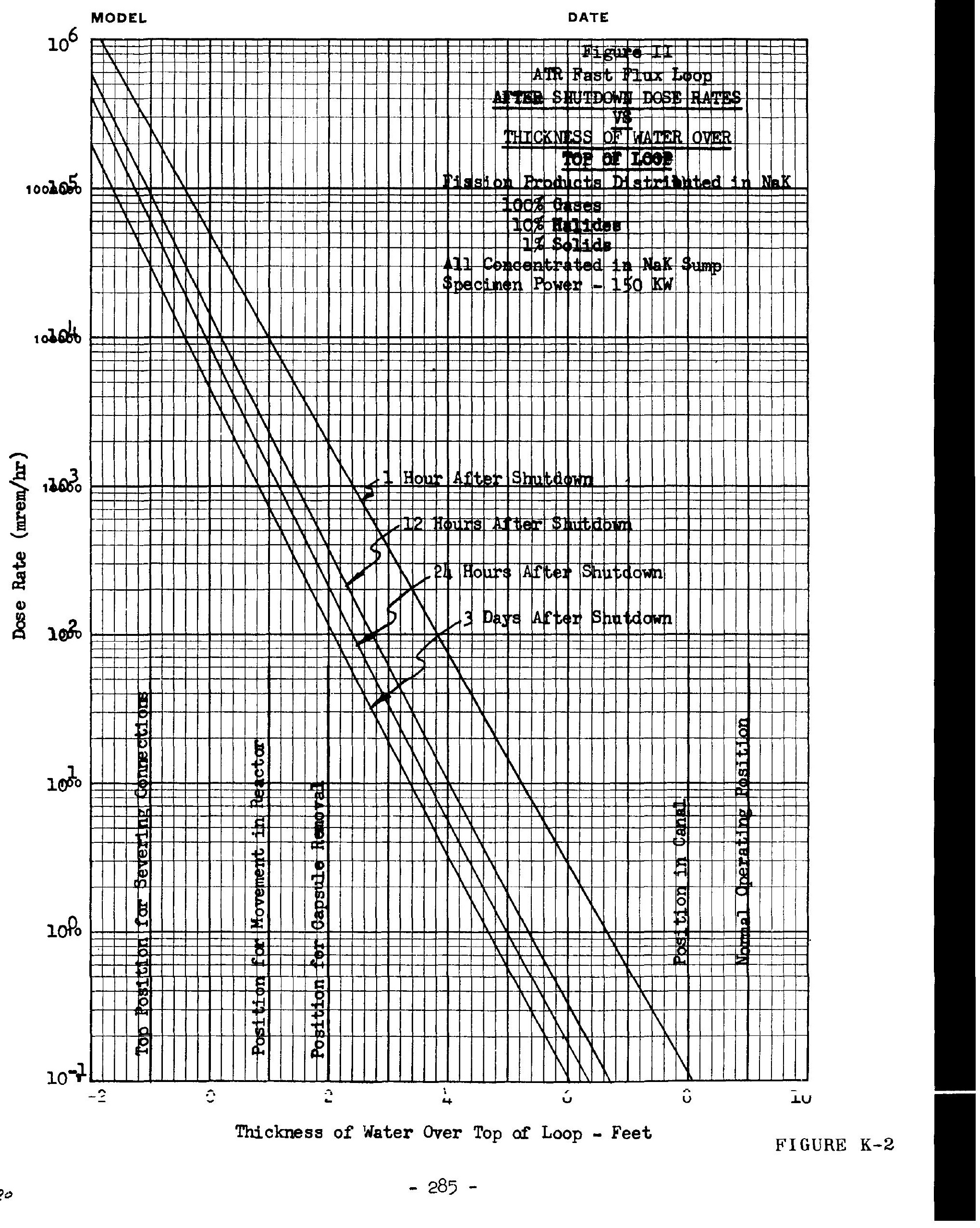


0

-

8 
APPENDIX L

Thermal Loop Shielding Analys is 


\section{APPENDIX L THERMAL LOOP SHIELDING ANALYSIS}

The following criteria required that an analysis be made of the radiation levels emanating from the thermal flux loop:

I. Personnel working around the reactor should not be subjected to excessive doses of radiation. The following conditions are of concern in this study.

A. Loop removal from reactor

1. Personnel atop the reactor may work through open refueling ports when the loop is in the in-core position.

2. Personnel atop the reactor work to make and break loop connections. Loop is raised to its uppermost position. Refueling ports are closed.

3. Personnel atop the reactor, loop being moved horizontally to the drop tube.

4. Loop being handled in canal.

B. Personnel atop the reactor work through open refueling ports to change capsule experiments. Loop is in its incore position. Reactor water level is at elevation 92-93 feet.

C. Access to capsule trench, water level in reactor is at elevation $92-93$ feet.

II. Radiation damage to

A. Loop motors

B. Top head seals of adjacent loops

III. In both I and II above, consideration must be given to both unruptured and ruptured test specimens in the thermal loop.

At the time this report was prepared, the analysis had not been completed. Considerable redesign and reanalysis must be done during Title I in order to arrive at a loop design that will satisfy all these criteria. 
Described herein are the problems encountered in attempting to meet the various design criteria and some possible solutions to these problems.

The principal sources of after-shutdown radiation in the thermal flux liquid metal package loop are gamma rays from fission products resulting from fuel sample defects and induced activities in the loop structural materials and primary coolant. Calculations show that the primary coolant sodium activation is the major contributor to the after-shutdown dose rates when the fuel pin cladding is not ruptured. Fission product activity and structural materials activation are negligible in comparison to the coolant activation. For the ruptured fuel pin case, primary coolant activation is still the largest contributor to the dose rates, with the fission products distributed in the coolant contributing about $20 \%-30 \%$ to the dose rate.

The sodium sump is the uppermost location of sodium when the loop is in its normal operating (vertical) position. Therefore, this sump is the source of controlling radiations in all cases since the primary coolant or distributed fission products are the major contributors to the after-shutdown dose rates. This analysis is, therefore, chiefly concerned with general sump arrangements including sump shielding, resulting dose rates and heat generation due to sump sources. All calculatipns are based on an irradiation time of 10,000 hours.

I-A-1. This condition was not analyzed.

I-A-2. When the loop is in its uppermost position, the top of the sodium sump is shielded at the side by $4 \mathrm{ft}$. 3 inches of reactor water and by the 8 -inch thick top shield plate. A shield plug above the sump attenuates direct streaming vertically upward from the sump.

The calculations were based on equilibrium sodium-24 activity in the sodium sump. This sodium activation occurs at $1225^{\prime} \mathrm{F}$ with a sodium density of $0.809 \mathrm{gm} / \mathrm{cc}$. The fission product calculations for the ruptured fuel pin case were based on distribution of fission products in the sodium with an assumed concentration of $100 \%$ of gases, $10 \%$ of halides, and $1 \%$ of solids in the sodium sump. 
The calculation of the equilibrium sodium activity was made using the equation:

$$
\lambda N=N_{s} \bar{\sigma}_{\text {act }} 0_{\text {th }}\left(1-e^{-\lambda t} 1\right) e^{-\lambda t_{2}}
$$

where

$$
\begin{aligned}
N_{s} & =\frac{\rho N_{0} I e}{A_{s}} \quad \text { atoms/cc }=\text { atomic density of coolant } \\
\rho & =\text { coolant density } \\
N_{0} & =\text { Avagadro's number } \\
I_{e} & =\text { atomic abundance of parent isotope } \\
A_{s} & =\text { atomic weight of element } \\
\bar{\sigma}_{\text {act }} & =\text { activation cross section for sodium corrected } \\
& \text { for temperature and Maxwellian distribution } \\
\sigma_{\text {th }}= & \text { activating thermal flux } \\
\lambda & =\text { decay constant of sodium }-24\left(T_{1 / 2}=15.1 \mathrm{hrs}\right) \\
t_{1} & =\text { irradiation time } \\
t_{2}= & \text { decay time }
\end{aligned}
$$

Equilibrium sodium-24 activity in the sump was found to be $6.1 \times 10^{11}$ dis/cc-sec at one hour after shutdown.

Fission product source strengths were computed with the use of digital computer programs which solve coupled time-dependent differential equations describing fission product buildup and decay in a reactor core. The programs compute the concentration in a reactor core of each isotope in each of a number of specified fission product chains, and group the activities by energy. The programs are limited to a maximum of five isotopes in a chain, six fission product buildup times, and six decay times after shutdown.

The attenuation calculations through water above the sump were made by assuming a series of vertical line sources to represent the annular sodium sump. A gamma yield of one photon per disintegration of 2.76 Mev and of $1.38 \mathrm{Mev}$ energy from sodium-24 decay was considered. The fission product activities were grouped by energy on the computer program in six groups of average energies $0.35 \mathrm{Mev}, 0.90 \mathrm{Mev}, 1.40 \mathrm{Mev}, 1.80 \mathrm{Mev}$, $2.30 \mathrm{Mev}$, and $2.60 \mathrm{Mev}$. The line source equation for the dose rate used was: 


$$
\text { where } \begin{aligned}
\mathrm{DR}= & \frac{\mathrm{B}_{\mathrm{r}} \mathrm{KS}_{\mathrm{L}}}{4 \pi \mathrm{a}} \quad\left[F\left(\emptyset_{1}, \mathrm{~b}\right)-F\left(\phi_{2}, \mathrm{~b}\right)\right] \\
\mathrm{B}_{\mathrm{r}}= & \text { Dose buildup through water } \\
\mathrm{K} & =\text { Conversion factor; flux to dose rate at } \\
& \text { specific energy } \\
\mathrm{S}_{\mathrm{L}}= & \text { Source strength of line-source }
\end{aligned}
$$

It should be noted that self-attenuation of the source, material is not allowed for in this equation. Dose rates from activated sodium in the heat exchanger region and in the test section were found to be lower than those from the sump by factors of approximately 100 and 2,000, respectively.

The initial after-shutdown radiation calculations were performed assuming the loop in a raised position with no allowance for the 8 -inch thick steel plate in the vessel head and were calculated for one hour after reactor shutdown. These calculations indicated unreasonably high dose rates at the water surface of $1.94 \times 10^{7} \mathrm{mrem} / \mathrm{hr}$ with unruptured fuel pins and $3.03 \times 10^{7} \mathrm{mrem} / \mathrm{hr}$ with ruptured fuel pins. These numbers, when reduced by an estimated attenuation factor of 200 for the 8-inch steel plate, resulted in dose rates of approximately $9.7 \times 10^{4} \mathrm{mrem} / \mathrm{hr}$ and $1.5 \times 10^{5} \mathrm{mrem} / \mathrm{hr}$, respectively, for the unruptured and ruptured fuel pin cases.

All of the above calculations were made with an original sump configuration in which the top of the sump was located 5'9' above the top of the test specimen and the sump was assumed to be 1 foot long with an outside diameter of 5 inches and an inside diameter of 1-5/8 inches. There was no shielding in or around the sump. Because of the high dose rates found for this loop position with these assumptions, no calculations were made for other loop positions with these same assumptions.

The next analysis considered 3 days shutdown time and all steel shielding in place atop the reactor. This longer shutdown time is much nearer the actual shutdown time at which loop handling operations might occur, and therefore all subsequent calculations for loop handling used this assumption. Another assumption for these later calculations was that the equilibrium sodium-24 activity in the sump is $12.4 \%$ of the equilibrium sodium -24 activity in the loop. This was based on diffusion 
calculations referenced in Pratt \& Whitney Aircraft report TIM No. 558.

Using these latter assumptions, and further assuming that a tungsten shield plug above the sodium sump effectively attenuates the direct loop streaming, the dose rate at the top of the 8 -inch steel plate where handling operations occur was calculated to be approximately $30 \mathrm{mrem} / \mathrm{hr}$ for the unruptured fuel pin case and approximately $37 \mathrm{mrem} / \mathrm{hr}$ for the ruptured fuel pin case.

All of these later calculations were made by assuming self-attenuating line sources to represent the sump annulus. This line source equation is as follows:

$$
D R=\frac{B_{r} K S_{L}}{4 \pi a} \quad e^{\mu} C_{-b_{1}}\left[\frac{\left.E_{2}{ }^{(\mu} C\right)}{C}-\frac{E_{2}{ }^{\left(\mu_{s} d\right)}}{d}\right]
$$

where $B_{r}=$ Dose buildup for iron applied for entire $b_{1}$ of water $\mathrm{K}=$ Conversion factor; flux to dose rate at specific energy

Dose rates from the heater section, heat exchanger section and test section were found to contribute approximately half of the quoted dose rates.

I-A-3. When the loop is lowered two feet from its uppermost position (see I-A-2) for horizontal transport to the drop tube, there is about one foot of water over the top of the loop. With the same sump configuration (12" high, 5" O.D., 1-5/8" I.D., 3-1/2" thick tungsten plug over the sump) and with refueling ports open, the dose rates through the ports are $367 \mathrm{mrem} / \mathrm{hr}$ for the unruptured fuel pincase and $542 \mathrm{mrem} / \mathrm{hr}$ for the ruptured pin case. If a shielding viewing window equivalent to $4^{\prime \prime}$ of steel is placed in the open port, these dose rates drop to 23 $\mathrm{mrem} / \mathrm{hr}$ and $29 \mathrm{mrem} / \mathrm{hr}$.

After analyzing cases I-A -2 and I-A-3 with $12.4 \%$ of equilibrium sodium-24 activity, and after studying expansion volumes, transient temperatures, pumping effect of motor shaft, etc., it was decided that this $12.4 \%$ is too optimistic for the thermal loop. The actual number will probably be somewhere between $12.4 \%$ and $100 \%$ activity. New calculations were made using $100 \%$ activity, giving maximum after-shutdown dose rates.

This more conservative assumption resulted in the following dose rates for the ruptured fuel pin cases described above. 
Equilibrium Na-24 Activity in Sump

Case I-A-2

Case I-A-3

(open ports)
$\mathrm{Na}-24$

Fission Products

$\mathrm{Na}-24$

Fission Products

$\mathrm{Na}-24$

Case I-A-3

(shielded ports)

$$
100 \%
$$

$145 \mathrm{mrem} / \mathrm{hr}$

$7 \mathrm{mrem} / \mathrm{hr}$

$152 \mathrm{mrem} / \mathrm{hr}$

$1,632 \mathrm{mrem} / \mathrm{hr}$

$175 \mathrm{mrem} / \mathrm{hr}$

$\overline{1,807} \mathrm{mrem} / \mathrm{hr}$

$102 \mathrm{mrem} / \mathrm{hr}$

$6 \mathrm{mrem} / \mathrm{hr}$

$\overline{108} \mathrm{mrem} / \mathrm{hr}$

\section{$12.4 \%$}

$37 \mathrm{mrem} / \mathrm{hr}$

$542 \mathrm{mrem} / \mathrm{hr}$

$29 \mathrm{mrem} / \mathrm{hr}$

Dose rates from the heater section, heat exchanger section, and test section contribute approximately $10 \%, 11 \%$ and $12 \%$, respectively to the above cases.

I-A-4 Canal handling was not analyzed.

I-B Vessel Entry with Lowered Water Level

With the loop in its in-core position, the sodium sump sits well above the core and will contribute to the dose rate above the water if the water level is lowered to permit entry for loop welding operations, etc., inside the vessel. With the water level 10 feet over the top of core, dose rates at the water surface from $\mathrm{Na}-24$ in the sump are as follows:
1 Day Shutdown
3 Days Shutdown
$320 \mathrm{R} / \mathrm{hr}$
$35 \mathrm{R} / \mathrm{hr}$

With 11 feet of water over the core, the numbers are:
1 Day Shutdown
$70 \mathrm{R} / \mathrm{hr}$
3 Days Shutdown
$8 \mathrm{R} / \mathrm{hr}$

With ruptured fuel pins and the same distribution of fission products as assumed earlier located in the sump, the dose rate with 10 feet of water over the core becomes $45 \mathrm{R} / \mathrm{hr}$ after 3 days shutdown.

Because of these high dose rates, the thermal loop should be removed from the reactor during any operations that require reactor vessel entry. I-C Capsule Experiment Removal - Lowered Water Level

Removal of capsule experiments requires that the reactor water level be lowered to approximately $10^{\prime}$ to $l^{\prime} l^{\prime}$ over the top of the core. During this operation personnel may be required above the open reactor head access ports and access into the capsule access trench will be required. 
Therefore, dose rates at both locations were checked to determine allow able access times.

After the work described in previous sections was done, more detailed analyses were made of the thermal conditions in the loop. These indicated that a 12-inch deep sump would not accomodate the thermal expansion of the sodium under all operating conditions. Therefore, a new sump configuration was established: 18 inches deep, sodium O.D. of 4-1/2 inches, sodium I.D. of 1.8 inches (the pump shaft and a baffle run down through the center of the sump), and a 3-1/2-inch thick tungstenshield between sump and motor. Equilibrium Na-24 activity was assumed in the sump. Shielding credit was taken for the loop walls, reactor coolant water, and vessel walls, as a pplicable.

The resulting dose rates are as follows at 1 hour after shutdown:

Capsule Access Trench

$\begin{array}{ll}\text { Na-24 } & 452 \mathrm{mrem} / \mathrm{hr} \\ \begin{array}{l}\text { Fission } \\ \text { Products }\end{array} & \frac{61}{513} \mathrm{mrem} / \mathrm{hr} \\ & 513 \mathrm{mrem} / \mathrm{hr}\end{array}$

\section{Reactor Head Access Port}

$\mathrm{Na}-24$

$11.4 \mathrm{rem} / \mathrm{hr}$

Fission

Products

$$
\frac{2.1}{13.5} \mathrm{rem} / \mathrm{hr}
$$

It was apparent that dose rates from a bare (unshielded) sump would be too high. In studying the feasibility of shielding the sump, the use of external shielding was considered but not studied, since it was felt that internal shielding might be satisfactory. However, with internal shielding taking up some of the radial space in the sump, the depth of sodium must necessarily increase to accommodate the required expansion volume.

With $1 / 2$-inch thick tungsten shielding immediately inside the loop wall around the sump, the sump configuration is:

$\begin{array}{ll}\text { Shield O.D. } & 4-1 / 2 \text { inches } \\ \text { Shield I.D. } & 3-1 / 2 \text { inches } \\ \text { Sodium O.D. } & 3-1 / 2 \text { inches } \\ \text { Sodium I.D. } & 1.8 \text { inches }\end{array}$

With this radial configuration, the sodium extends up into the 8 -inch diameter portion of the loop. The dose rates are: 


\section{Capsule Access Trench}

$\mathrm{Na}-24$

Fission

Products
$5 \mathrm{rem} / \mathrm{hr}$

$1 \mathrm{rem} / \mathrm{hr}$

$6 \mathrm{rem} / \mathrm{hr}$

Reactor Head Access Port

$\mathrm{Na}-24$

Fission

Products
$9 \mathrm{rem} / \mathrm{hr}$

$2 \mathrm{rem} / \mathrm{hr}$

$11 \mathrm{rem} / \mathrm{hr}$

These calculations show that adding the tungsten shielding inside the sump decreases the reactor access port dose rate about $20 \%$ but increases the capsule access trench dose rate by a factor of approximately 12 . The reduction in rate at the top of the reactor is realized because the slant height of the shielding and, therefore, its effective thickness is great in comparison to the $r$ ise in the level of the sodium source. The increase in rate at the access trench is due to the rise in sodium level which causes the radiation to pass through the shielding at a reduced slant height angle, thus reducing the effective thickness of the shielding.

It is apparent that a great deal of study remains to be done to overcome these radiation problems.

\section{II-A Motor Winding Protection}

It has been estimated that insulation in the motor winding should be limited to an integrated dose of $10^{9}$ Rads. Therefore, a tungsten shield plug was placed over the sump to protect the windings. It was found that $3.5^{\prime \prime}$ of tungsten between the sodium sump and motor windings permits operation for greater than 10,000 hours without exceeding the $10^{9}$ Rad dose. Additional shielding s placed above the motor to prevent gamma streaming up the loop for personnel protection during handling.

Since absorption of gamma rays produces heat in shield materials, heat generation rates in the tungsten shield plug were computed. Original calculations were quite conservative and indicated heat removal from the plugs may present a problem. Therefore, a different shield configuration was tried. This configuration was a laminated tungsten shield located in the sump. The tungsten would be 1/4" thick slabs with sodium above and below these slabs with the last slab above all the sodium. This configuration proved unfeasible when it was found that the motor windings would receive the allowable dose of $10^{9}$ Rads in approximately 400 hours. 
Because of the high dose rates with the laminated shield, more detailed calculations of the heat generation in the solid tungsten shield plug and motor shaft were performed. These detailed calculations gave heat generation rates considerably lower than the original conservative calculations. An analysis was started to determine if the heat generated in the solid tungsten shield plug and motor shaft is removed without producing excessive temperatures in these parts and in the motor shaft bearing which should probably be maintained below about $250 \mathrm{~F}$. Sufficient time was not available to complete a detailed analysis. However, preliminary calculations indicate that the heat is removed without raising the temperature above allowable limits. The calculations also indicated that heat in the tungsten shield plug and pump shaft due to thermal radiation from high temperature sodium in the sump could be higher (depending on sodium temperature) than the heat due to the absorption of gamma rays. This problem could possibly be solved by (1) using thermal radiation heat shields between the sodium and the pump shaft and the tungsten or (2) devising a means to minimize circulation between the sodium in the sump and sodium in the loop the reby lowering the temperature of the sodium in the sump. These problems will have to be analyzed in detail in Title I. From a shielding viewpoint the original $3.5^{\prime \prime}$ tungsten plug proved feasible and the better arrangement.

A further consideration of motor damage concerns the effects of the radiation from the the rmal loop sump upon the adjacent fast loop motor. If the original height of the PW-19 loop is maintained, the fast loop motor will be at very nearly the same elevation as the thermal loop sump. It is expected, but has not been calculated, that the fast loop motor will be damaged fairly quickly. If the fast loop is lengthened (see IDO-24041, Supplement 1), its motor will be some what above the thermal loop sump and, therefore, the radiation damage the fast loop motor incurs will be less. Further study of this problem is required during Title I work.

I I-B

Damage to seals of adjacent loops and other materials seems unlikely from loop handling operations. For example, if the loop is raised at 3 days shutdown, dose rate over $4^{\prime} 3^{\prime \prime} \mathrm{H}_{2} \mathrm{O}$ at vessel head is $35 \mathrm{R} / \mathrm{hr}$ from equilibrium $\mathrm{Na}-24$ activity in the sump. 
If initial damage to the adjacent seals occurs at $2 \times 10^{6} \mathrm{Rad}$, this would allow $\frac{2 \times 10^{6}}{35}=5.7 \times 10^{4}$ hours from $\mathrm{Na}-24$ in loop handling loop in raised position) prior to initial damage.

Summary

It appears that shielding is required in or around the sump to protect the motor windings and bearings from radiation damage and to protect operating personnel from overexposure during loop handling and other reactor operations. At this time no firm shielding arrangements can be made; further design work must be pursued. 
APPENDIX M

Preliminary Fast Flux Package

Loop Handling Study 


\section{PURPOSE AND SCOPE}

The purpose of this document is to define the operations and conditions for handling of the fast flux package loop.

The procedures outlined in the study describe handling concepts of preliminary designs and design concepts existing at the time the document was written. Modifications should be made, if required, to accommodate changes resulting from later design work.

When approved designs are completed, it is recommended that a mock-up study be made.

The conceptual procedures for removal and installation of a loop in the reactor and for moving a loop between the reactor and the hot cell are covered. The procedure steps are outlined in the order in which the work will normally be done. An alternate procedure is given if a need for it is apparent.

A general description of the loop is made in terms of physical characteristics, and location is given for major radiation sources.

From shielding calculations reported in Design Data Sheet $R-6008$, it appears that, under certain conditions, the loop cannot be handled manually by personnel working through the top head of the reactor. Most certainly the thermal flux loop cannot be handled this way, as discussed in IDO-24043, Part I I, Appendix B. It was decided, therefore, that both loops would be handled remotely. It was also decided that the loops would be handled through the reactor drop tube (neither loop can pass through the 6 inch diameter holes in the reactor top head closure plate, and removal through the refueling ports into a shielded cask would be expensive and would seriously hamper other reactor operations).

All of the procedures herein are based on the assumption that dose rate and exposure time combination can be adjusted to prevent operator over-exposure. Validation of this assumption can be made when the loop design is firm. tion 5 .

A description of the tools required for loop handling is given in Sec-

\section{GENERAL DESCRIPTION}

The in-reactor section of the fast flux loop facility is located in the northeast ( $40 \mathrm{MW}$ ) lobe of the ATR core. It consists of a loop extension assembly and an attached package loop assembly held together conceptually by screw type fasteners such as socket-head or hex head bolts removable from above by long handled tools. The loop assembly extends from the bottom end of the extension tube to a point about 5 inches below the core midplane.

The extension assembly is cylindrical in shape, 5-15/16" diameter and $10^{\prime}-4-1 / 2^{\prime \prime}$ long. The bottom of an integral collar is located $12^{\prime \prime}$ from iile lup enu. Inis coiliar rests on tne top nead closure plate to provide support of the loop. A loop seal flange is bolted to the top head closure 
plate and locks the collar in the plate. The loop and loop extension as semblies are also supported laterally at two locations within the vessel: one at the junction of the extension and loop assemblies and the other above the reactor core. These supports, to be designed in Title I, not only position the loop in reference to the core but also snub out any primary reactor coolant flow-induced vibrations. The secondary coolant helium lines and power and instrument leads pass from the out-ofreactor section, through the extension assembly, and into the loop as sembly. Break away connections in the instrument and power lines and silver soldered joints in the helium lines are located at the top end of the extension assembly and at the joint between the extension and loop assemblies.

The loop assembly is generally circular in cross section. The maximum diameter is 5-15/16", but an external section of helium return line runs up to the outside of the pressure tube and increases the clear ance required for handling. This helium line prevents the loop from be ing removed through the loop access hole in the top head closure plate.

During handling, the loop extension assembly is replaced by a handling extension 5-15/16" dia. x 8-1/2" long. With this extension in stalled the clearance envelope required for handling is $7^{\prime \prime}$ dia. $x 12^{\prime}-1^{\prime \prime}$.

\section{REFERENCE DOCUMENTS}

Tool Information

Name

Hot cell transfer cart

Canal transfer concept

Fast loop thimble

Loop storage rack

No. I head plier tool

Heating element

Helium line plug

Loop pick-up tool

Loop shield plug

Loop handling extension

Loop transfer tool

Three leg sling

Shielded loop handling sling

Bayonet operating tool

Canal-to-cell lifting tool

*Refueling port viewing window

Capsule handling hook tool

Loop puller as sembly

Canal transfer tube insert handling tool

\begin{tabular}{|c|c|c|}
\hline $\begin{array}{c}\text { Drawing } \\
\text { No. } \\
\end{array}$ & $\begin{array}{c}\text { Figure } \\
\text { No. } \\
\end{array}$ & $\begin{array}{c}\text { Tool } \\
\text { Description } \\
\text { Paragraph } \\
\end{array}$ \\
\hline SKC-2979E & $(M-3)$ & 5.1 \\
\hline SKC -2981E & $(M-4)$ & 5.1 \\
\hline$* *$ & & 5.2 \\
\hline$* *$ & & 5.3 \\
\hline SKC -2874E* & $(M-2)$ & 5.4 \\
\hline$* * *$ & & 5.5 \\
\hline$* * *$ & & 5.6 \\
\hline$* 2 *$ & & 5.7 \\
\hline$* * *$ & & 5.7 \\
\hline$* *$ & & 5.8 \\
\hline SKC -2980 & $(M-5)$ & 5.9 \\
\hline$* * *$ & & 5.9 \\
\hline$* *$ & & 5.10 \\
\hline$* * *$ & & 5.11 \\
\hline$* * w^{2}$ & & 5.12 \\
\hline$* * *$ & & 5.13 \\
\hline
\end{tabular}

SKC -2645E* (M-1) S-R-114, Para. 5.1***

SKC-3042E* (M-6) Spec.No. MS -1 19**** 水* 
Reference Documents (cont'd)

Loop Information

A. Drawings

Name

Drawing No.

Fast Flux Liquid Metal Package Loop

Figure 3,2, IDO-24041

B. Reports

Name

Number

Design Criteria for a Fast Flux Liquid

IDO-24041

Metal Loop in the Advanced Test Reactor

Fast Flux Liquid Metal Package Loop

DDS No. R-6008

Radiation Dose Rates

Decay Periods for the Loop Handling

Secondary Coolant Impurities Activations

DDS No. R-6007

DDS No. R-4017

* Capsule handling hook tool

S-R - $114 * * *$

* Loop puller assembly

Spec. No. MS-1 19\%**

\section{Procedure Information}

Name

Fast flux liquid metal pack loop removal scheme 2 , sheet 1

Fast flux liquid metal package loop removal scheme 2 , sheet 2

Fast flux liquid metal package loop removal scheme 2 , sheet 3

Fast flux liquid metal package loop installation scheme 2 , sheet 1

Fast flux liquid metal package loop installation scheme 2 , sheet 2
Number $\quad$ Fig. No.

$\begin{array}{ll}\text { SKC }-3178-E & M-7 \\ \text { SKC }-3179-E & M-8 \\ \text { SKC-3180-E } & M-9 \\ \text { SKC -3181-E } & M-10 \\ \text { SKC -3182-E } & M-11\end{array}$

* The tool shown on this drawing is the type of design contemplated.

**: Design to be provided in Title I

**** Not included in this document 
4. HANDLING PROCEDURES

4.1 Removal of a Loop from the Reactor

Initial Conditions and Preparation

1. The reactor has been down long enough that the dose rates are sufficiently low to allow this procedure to be initiated. The dose rates, as given in the detailed procedure steps, are the contribution of the fast flux loop only and are based on unruptured fuel pins with all fission products retained in the pins. During some procedural steps, there may be sufficient radiation streaming between the loop access hole in the top closure plate to require some local shielding.

2. The reactor vessel ventilation system is in operation.

3. The vibration dampeners are removed from the fast loop.

4. The package loop transfer tool is installed in the northeast refueling port with the slide in the fully retracted position.

5. The drop tube is uncovered and a loop handling sling with a shielded cable is installed in the north refueling port over the drop tube. The cords for underwater lights, as required, pass between the shielding and the vessel head. The top head shielding over this port is replaced.

6. A viewing window is installed in the southeast refueling port.

7. The loop transfer shield plate and shield cylinder are removed. Note: Later ATR design work indicates that these parts may not be removed. Appropriate adjustments in the loop handling scheme will have to be made in Title I.

8. The fast loop thimble is in the canal transfer tube, and the transfer tube is in the reactor position.

9. The secondary coolant, helium, has circulated long enough, as indicated by the monitor up stream from the filter, after reactor shutdown, to flush the secondary coolant lines of activated gaseous impurities. The helium pressure is reduced to atmospheric.

10. The Hot Cell Transfer Cart is in the reactor building position, the position to accept a loop from the storage canal.

\section{$\underline{\text { Procedure Outline }}$}

1. Disconnect the instrument and power leads at the top of loop extension assembly.

2. Disconnect the secondary coolant helium lines at the top of the loop extension assembly and seal the open ends. 
3. Pull the loop up through the top head closure plate and hang it on the plate in position for removal of the loop extension assembly and installation of the handling extension.

4. Disconnect the loop extension tube, raise it $10^{\prime \prime}$, and disconnect the helium lines and instrument and power leads between the tube and the loop. Remove the loop extension assembly, and install the loop handling extension.

5. Lower the loop and place it on the package loop trans fer tool.

6. Move the loop over the drop tube and transfer it to the shielded loop handling sling.

7. Pass the loop through the drop tube into the fast loop thimble, and shift the loop thimble to the canal position.

8. Move the loop thimble to the loop storage rack.

9. Move the loop thimble and place it on the hot cell trans fer cart, move the cart under the hot cell entrance, and raise the fast loop thimble into the entrance opening.

Detailed Procedure

1. Disconnect the instrument and power leads at the top of the loop extension as sembly.

(a) Check the dose rate at the top surface of the top head closure plate. Expected dose rate $-5 \times 10^{-5}$ $\mathrm{mrem} / \mathrm{hr}$.

(b) Open the instrument and power switches. If it is deemed necessary from further study during Title I that instrument and/or power leads are required during handling, the handling extension can be suitably designed to accommodate these services.

(c) Disconnect the leads.

2. Disconnect the secondary coolant helium lines at the top of the loop extension assembly, and seal the open ends.

(a) Close the out-of-pile helium system isolation valves, and open the in-pile section helium bleed valves.

(b) Remove the insulation from the secondary coolant helium lines at the silver soldered joints.

(c) By means of heating elements, melt the helium line joint solder. 
(d) Manually pull the joints apart.

(e) By means of an expandable helium line plug, seal the open ends of the lines.

3. Pull the loop up through the top head closure plate, and hang it on the closure plate in position for removal of the loop extension as sembly and installa tion of the handling extension.

(a) Insert an indexing bar in the loop extension assembly. Hold the bar to prevent rotation of the loop during steps (d) and ( $g$ ).

(b) Remove the fasteners from the loop seal flange.

(c) Attach a loop pick -up tool to a one leg sling and to the loop extension assembly. Attach the sling to the two ton crane.

(d) Using the crane and observing the load indicator, pull the extension tube up $10^{\prime \prime}$. Hold the indexing bar to prevent gross rotation during lifting.

(e) Check the dose rate at the top surface of the top head closure plate. Expected dose rate $-1.5 \times 10^{-6}$ $\mathrm{mrem} / \mathrm{hr}$.

(f) By means of the indexing bar, rotate the loop clockwise 450 so that the helium return line will clear the neck shim housing.

(g) Pull the loop extension and loop assemblies up an additional $9^{\prime}-1^{\prime \prime}$. Hold the indexing bar to prevent gross rotation during lifting. Temporary scaffolding or ladders may be required to permit work to be done on top of the loop extension.

(h) Check the dose rate at the top of the top head closure plate. Expected dose rate $-0.5 \mathrm{mrem} / \mathrm{hr}$.

(i) Install the loop holding collet.

(j) Remove the indexing bar, the loop pick-up tool, and the loop seal flange.

4. Disconnect the loop extension tube, raise it $10^{\prime \prime}$, and dis connect the secondary coolant helium lines and instrument and power leads between the tube and the loop. Remove the loop extension assembly and install the loop handling extension.

(a) Attach a one leg sling to the two ton crane and to the loop pick-up tool. Attach the tool to the loop extension assembly.

(b) Disconnect the fasteners between the loop and the extension assembly and lift the tube $10^{\prime \prime}$.

(c) Check the dose rate at the top of the top head closure plate. Expected dose rate $-0.5 \mathrm{mrem} / \mathrm{hr}$. 
(d) Disconnect the instrument and power leads.

(e) By means of heating elements, melt the soldered joints of the helium lines.

Before doing the following step, make sure that all is ready to immediately do step (h) just as soon as the loop extension assembly is out of the way, so that the helium, instrument and power leads may be sealed off as soon as possible to prevent contaminants from entering the helium lines.

(f) Manually pull the joints apart.

(g) Move the loop extension assembly to a storage location and detach the pick-up tool and sling.

(h) Manually place the loop handling extension on the end of the loop and install the fasteners.

(i) Leak check the O-ring seal.

(j) Insert the package loop pick-up tool through the loop shield plug and attach a one leg sling to the tool. Attach the two ton crane to the sling, and lift the assembly.

(k) Transport the assembly to the loop handling extension and manually guide and install the pick-up tool in the loop handling extension.

5. Lower the loop and place the loop on the package loop transfer tool.

(a) Raise the loop I" $^{\text {"and }}$ remove the loop holding collet.

(b) Lower the loop until the shield plug on the sling rests on the top head closure plate. Continue down until the lower elevation indicator mark on the pick-up tool is even with the top of the shield plug.

(c) Index the package loop transfer tool counterclockwise to the fast loop position and lock it in place. Extend the arm to the fast loop position as indicated by a pre-determined reading of the dial.

(d) Insert a torque and holding bar in the pick-up tool and index the loop to the position for lowering it on the transfer tool. Index to the position mark on the top head closure plate.

(e) Lower the loop until it rests on the transfer tool as shown by the top elevation indicator mark on the pick-up tool being even with the top of the

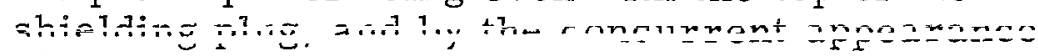
of slack in the sling cable. 
(f) By means of the torque and holding bar in the pick-up tool, disengage that tool, pull it up, and install the holding pin in the bottom hole of the tool. Release the sling.

6. Move the loop over the drop tube and transfer it to the package loop handling sling.

(a) Retract the arm of the package loop transfer tool to the pre-determined transfer position mark.

(b) Release the transfer tool angular position lock and rotate the tool clockwise to the drop tube position. Engage the lock.

(c) Extend the arm of the transfer tool to the drop tube position stop.

(d) Manually install the shielded loop handling sling bayonet in the loop handling extension, and attach the sling to the two ton crane.

(e) Raise the loop 3".

(f) Retract the arm of the transfer tool to the insertion position; that position required for inserting the transfer tool into the Reactor Refueling Port.

7. Pass the loop through the drop tube into the fast loop thimble, and shift the thimble to the canal position.

(a) Lower the loop approximately $1^{\prime}-5{ }^{\prime \prime}$.

(b) Remove the viewing window from the southeast refueling port. Expected dose rate - $0.5 \mathrm{mrem} / \mathrm{hr}$.

(c) Continue to lower the loop into the drop tube and thimble. Observe through the southeast refueling port and assist with long handled hook tools as required. Rotate the crane hook swivel manually to avoid hanging -up of the loop at any point.

(d) Using a bayonet operating tool through the southeast refueling port, remove the handling sling from the loop handling extension.

(e) By means of the canal transfer device, shift the fast loop thimble to the canal position.

8. Move the fast loop thimble to the loop storage rack.

(a) Install the canal transfer tube insert handling tool in the fast loop thimble and attach the tool to the jib crane hook.

(b) Lift the thimble and transfer it to the storage canal crane hook.

(c) Check the dose rate at the canal water surface. Expected dose rate $-5 \times 10^{-4} \mathrm{mrem} / \mathrm{hr}$. 
(d) Move the thimble to the canal loop storage location and place it on the loop storage rack.

(e) Remove the canal transfer tube insert handling tool.

9. Move the loop thimble and place it on the hot cell trans fer cart, move the cart under the hot cell entrance and raise the fast loop thimble into the entrance opening.

(a) Install the canal transfer tube insert handling tool in the loop thimble.

(b) Attach the storage canal crane hook and lift the loop thimble free of the loop storage rack.

(c) Place the loop thimble in the hot cell transfer cart.

(d) Using a No. 1 Head Plier tool, install an in-cell handling eye in the loop.

(e) Move the cart to the hot cell position.

(f) Open the hot cell entrance and elevate the loop into the opening.

\section{Alternate Procedure Steps}

The following steps are to be taken in the event that unusual forces are experienced at the start of Step No. 3(d) of the regular loop removal procedure.

1. Break the loop loose from the top head closure plate.

(a) Remove the loop pick-up tool from the loop extension.

(b) Remove the crane hook.

(c) Replace the shield cylinder and the loop transfer shield plate.

(d) Install the bayonet of the loop puller assembly in the bayonet receiver.

(e) Install the frame of the loop puller assembly and connect the screw to the bayonet.

(f) Pull the loop up approximately 10", install the loop holding collet, and rest the loop on the collet.

(g) Remove the loop puller assembly, the bayonet receiver, the loop transfer shield plate, and the shield cylinder.

2. Repeat Step 3(c) and continue through the usual procedure to completion. 


\subsection{Installation of a Radioactive Loop in the Reactor}

Initial Conditions

1. Initial conditions 1 through 5 for removal of a radioactive loop from the reactor exist.

2. The north and southeast refueling ports are open with protective covers installed, but the top head shielding is in place.

3. The canal transfer tube is in the canal position.

4. The fast loop thimble is in the hot cell transfer cart and the cart is in the hot cell position.

5. The loop has been prepared for installation in the re actor and either of the following conditions may exist.

(a) The loop has been irradiated and contains an irradiated specimen, and a new filter has been installed on the loop.

(b) The loop and filter are new, the loop contains an irradiated specimen, but decay is sufficient to not require shielding over the refueling ports.

6. The loop is in position to be lowered from the hot cell into the fast loop thimble on the hot cell transfer cart.

\section{Procedure Outline}

1. Move the loop from the hot cell on to the hot cell trans fer cart, into the canal transfer tube, and into position for passage through the drop tube.

2. Raise the loop through the drop tube into the reactor, up through the top head closure plate, and hang it on the holding collet.

3. Remove the loop handling extension, make the secondary coolant helium line and the instrument and power lead connections between the loop extension assembly and the loop, and install the loop extension assembly.

4. Lower the 15op to the operating position, install all fasteners, remove all tools, and make the secondary coolant helium line and instrument and power lead connections abcve the loop extension assembly.

5. Install the vibration dampeners on the loop.

Detailed Procedure

1. Move the loop from the hot cell on to the hot cell trans fer cart, into the canal transfer tube, and into position for passage through the drop tube. 
(a) Open the hot cell entrance and lower the loop into the thimble.

(b) Move the hot cell transfer cart to the reactor building position.

(c) Using a No. 1 Head Plier tool, remove the canalto-cell lifting tool from the loop.

(d) Install the canal transfer tube insert handling tool in the loop thimble.

(e) Attach the storage canal crane hook and lift the thimble free of the hot cell transfer cart.

(f) Transport the thimble and place it on the jib crane and then into the canal transfer tube.

(g) Release the jib crane hook and remove the canal transfer tube insert handling tool.

(h) Move the loop thimble to the drop tube position.

2. Raise the loop through the drop tube into the reactor, up through the top head closure plate, and hang it on the holding collet.

(a) Retract the shielding from over the north refueling port.

(b) Lower an underwater light and a loop handling sling through the refueling port.

(c) By means of a bayonet operating tool install the sling in the loop handling extension, and attach the two ton crane to the sling.

(d) Retract the arm of the loop transfer tool to the stop, index the tool clockwise to the drop tube position, lock it in position, and then extend the arm to the drop tube position.

(e) Using the two ton crane, pull the loop from the drop tube and up into the reactor and place it on the fork of the loop transfer tool.

(f) Disconnect the loop handling sling from the loop handling extension by means of a bayonet operating tool.

(g) Retract the arm of the loop transfer tool to the transfer position mark and index the tool counterclockwise to the fast loop position, lock it in position and then extend the arm to the fast loop position.

(h) Pass the bayonet of the loop pick-up tool through the top head closure plate and install it in the loop handling fxtension Atta-h a ma loy cling t... the tool and to the two ton crane. 
(i) Lift the loop $3^{\prime \prime}$ and retract the arm of the loop transfer tool to the stop.

(j) Pull the loop through the top head closure plate, and install the loop holding collet.

(k) Detach the loop pick-up tool from the handling extension.

3. Remove the loop handling extension, make the secondary coolant helium line and the instrument and power lead connections between the loop extension tube and the loop, and install the loop extension assembly.

(a) Attach the loop pick-up tool to the loop extension as sembly.

(b) Disconnect the fasteners and manually remove the handling extension.

(c) Lift the loop extension assembly and place it $10^{\prime \prime}$ above the top of the loop.

(d) Make up the slip joints of the helium lines.

(e) Using a heating element, silver solder the joints.

(f) Pressurize the helium lines and leak check the joints.

(g) Make up the instrument and power lead connections.

(h) Lower the extension tube on the loop, and make up the fasteners for connecting the tube to the loop.

(i) Pressurize the extension tube, and leak check the $\mathrm{O}-\mathrm{ring}$ seal.

4. Lower the loop to the operating position, install all fasteners, remove all tools, and make the secondary coolant helium line and instrument and power lead connections above the loop extension tube.

(a) Insert an indexing bar in the extension tube.

(b) Lift the loop 1 " and remove the loop holding collet.

(c) Retract the shielding from the north refueling port and lower lights into the reactor.

(d) Observe through the refueling port and, by means of the indexing bar, position the loop and hold it so that helium return line clears the neck shim housing dur. ing the next step.

(e) Lower the loop until the loop support flange is $3^{\prime \prime}$ above the top head closure plate.

(f) By means of the indexing bar, position the loop to line up the key and keyway, and lower the loop into operating position.

(g) Remove the torque bar, the crane hook and the sling. 
(h) Install the loop seal flange.

(i) Make up the helium line joints, silver solder, and leak check.

(j) Make up the instrument and power line joints.

5. Install the vibration dampeners on the loop.

\section{TOOL DESCRIPTIONS}

\subsection{Hot Cell Canal Transfer Equipment}

This equipment will be used from an operator position on the canal parapet wall to transfer a loop and thimble between the reactor building and the hot cell entry position, and to elevate the loop into the hot cell entrance.

The equipment consists of a canal transfer cart, stabilizing and guide track, a drag line, and a drag line drive.

The cart consists of a frame, a thimble elevating mechanism, stabilizing and guide rollers, and hold down roller. The thimble elevating mechanism consists of a water operated hydraulic cylinder. The lines to the cylinder are joined by quick disconnects when the cart is under the hot cell entrance.

The stabilizing and guide tracks on which the cart runs are located on the bottom liner of the hot cell canal and $r$ un almost the full length of the canal. The inside stabilizing track at the $90^{\circ}$ turn has a compound curve designed to permit free movement of the cart around the turn. The endless roller chain drag line runs from the drive sprocket located at the bottom of the canal in the reactor building inside the guide track for the full length of the track and returns to the sprocket along the canal wall. The drive sprocket shaft runs vertically up the canal wall and is coupled by a roller chain drive to a reversible electric motor-reducer power unit located on the canal parapet wall. Limit switches are provided at the ends of the cart travel.

In use the loop thimble is placed on the cart, the drive start button is held down by the operator until the cart reaches the limit switch and automatically stops. The hydraulic lines are manually carried along the canal parapet wall. If the next operation is to move the loop into the hot cell, the hydraulic line joints are made up and the loop and thimble are elevated into the hot cell entrance opening. If the loop is to be moved out of the hot cell into the reactor building, the carriage is moved under the cell entrance with the thimble in place, the hydraulic line joints are made up and the thimble elevated into the cell entrance. The loop is then lowered into the thimble and the thimble is lowered to the cart. The cart is then moved to the reactor building.

\subsection{Fast Loop Thimble}

This equipment is used to contain the loop in an approximately verti-

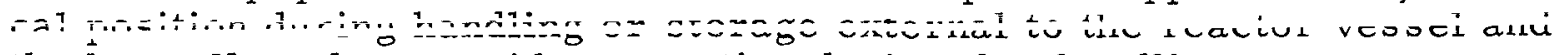
the hot cell, and to provide protection during that handling. 
The thimble is a stainless steel or aluminum tube capped at the bottom end. The diameter is stepped to provide proper support for the loop, and the top end is flared to facilitate entry of the loop as it passes through the drop tube into the thimble. The walls and end cap are perforated to permit canal water to cool the loop. Lugs mounted on the thimble wall are used for support when the thimble is in the loop stor age rack and when it is in the canal transfer cart. The flared section of the thimble is adapted to be lifted by means of the canal transfer tube insert handling tool.

\subsection{Loop Storage Rack}

This equipment, located in the storage canal, provides support and positioning for the thimble while the loop and thimble are being stored. It may also be used to store an empty thimble.

It consists of corrosion resistant structural material adapted to supporting and positioning the thimble lugs and to positioning the bottom end of the thimble.

\subsection{No. 1 Head Plier Tool}

This long handled tool is manually used from an operator position on the reactor floor near the parapet wall of the hot cell canal. It will be used to install the canal-to-cell lifting tool in the loop handling extension or to remove the lifting tool from that loop handling extension. In general, this tool is used to grasp a horizontal bar or rod.

The tool consists of a long handle assembly, a plier type gripping head and an actuating linkage for the head. This linkage runs from the gripping head through the handle to the operator position. The tool may be locked on the part being gripped.

The use of the tool to install the canal-to-cell lifting tool in the loop extension tube consists of locking the lifting tool in the plier jaws, pass ing the tools into the canal, inserting the bayonet end of the lifting tool into the bayonet receptacle of the loop extension tube and locking it, and unlocking and removal of the plier tool.

\subsection{Heating Element}

This tool is to be used by an operator above the top head closure plate to supply heat for connecting or disconnecting the soldered joints in the secondary coolant helium lines. It will be used both on the joints at the top of the extension tube and on those at the separation point between the loop extension assembly and the loop assembly.

The tool will consist of an assembly which can be clamped on the helium line adjacent to the joint to be heated so that the heating elements are around the joint. The assembly consists of electrical conductors, a frame, and electrical lead lines and connectors as required. A hand controlled switch will be provided in the power circuit.

$-314-\quad M-14$ 
The use of the tool consists of clamping the assembly to the helium line adjacent to the joint to be heated, making the electrical connections and closing the power circuit. Visual inspection of the solder will tell the operator when to open the power circuit.

\subsection{Helium Line Plug}

This equipment is to be used manually by an operator to seal the open ends of the helium lines above the loop extension assembly after the soldered joints have been disconnected for removal of the loop.

The plug is made of an elastomer and is expandable by means of a cam or other mechanism.

\subsection{Pick-Up Tool and Loop Shield Plug}

The loop pick-up tool has three applications. First, it is used to lift the extension assembly up through the top head closure plate; second, to carry the extension to storage; and third, to lower the handling extension and loop back down and onto the loop transfer tool. It will be installed by the operator using direct manual methods.

During the first and second applications the tool is connected to the extension assembly and to a one leg sling, and the sling is attached to the two ton crane. During the third application, it is connected similarly, but the loop shield plug is in place on the shank of the tool and rests on the top of the loop handling extension. The tool is a straight round bar with one end made as half of a bayonet fastener, and with the other end drilled for the shackle pin of a one leg sling. The bar is stepped to provide a ledge on which the loop shield plug rests and to prevent radiation streaming. Two additional holes are provided in the bar. The top hole is for insertion of a torque and indexing bar and the bottom one is for a holding bar. The holding bar prevents the tool from falling through the shield plug when the siing cable is slack. The torque and holding bar is used to position the loop and thus avoid damage to the helium return line during loop removal from the insertion into the in-core position, and to enabie the operator to place the loop on the loop transfer tool. Also, it is used for engaging the bayonet fastener.

\subsection{Loop Handling Extension}

This piece of equipment provides a means of sealing the helium lines after removal of the loop extension, and provides a receptacle for the bayonets of the loop pick up tool, the shielded loop handling sling, and the canal-to-cell lifting tool.

\subsection{Loop Transfer Tool}

This tool is installed in the northeast refueling port by means of the two ton crane, a three leg sling, and manual guiding. The fasteners are installed by direct access methods. It is used to transfer the loop from one position to another within the reactor vessel. The moving operation is done remotely from an operater nosition above the northeast refiuc? port. 
The tool consists of a base which is bolted and doweled to the refueling port integral flange, a column, an arm, a slide and fork weldment, a slide drive mechanism, and position indicators and position locks.

The base houses the bearings which align the column vertically, and supports the vertical positioning bearing. Holes for attaching a three leg sling for lifting the assembled tool are provided in the base. The base also serves as a radiation shield. The arm is attached to the bottom end of the column, extends horizontally and serves as a support and guide for the slide. The slide moves in and out of the arm carrying the integral fork on which the loop rests. The slide drive mechanism is a hand crank driven gear train which runs from the slide to the operator position above the refueling port. It is supported by the arm and column from brackets and structure as required. A slide position indicating device is located at the end of the mechanism at the hand crank. Matching holes are in the column flange and the base. These holes indicate the position of the arm to the operator. A pin is provided for insertion into the holes to lock the arm in a given position while the slide is moved in or out or while the tool is inserted into the refueling port.

To move a loop, the tool is installed in the refueling port, the arm is indexed to the loop position, and the slide is extended to a specified point. The loop is lowered on to the fork, the slide is withdrawn to a predeter mined point, and the arm is indexed to a new position. The loop is then lifted from the fork and the slide is withdrawn.

\subsection{Shielded Loop Handling Sling}

This sling is used to lift a loop from the loop transfer tool, and to lower it through the drop tube and into the thimble, during the removal of a loop from the reactor vessel. It is also used in a reverse manner, with the shielding and operating tube removed, to bring a loop into the vessel. Shielding is installed in the north refueling port by means of the two ton crane, and the sling is manually installed in a hole in the shielding.

The sling consists of a cable with an eye in one end and a bayonet fitting on the other, a removable operating tube, a holding pin, and a handle. The bayonet is adapted for engagement with the loop handling extension, and the eye is used on the two ton crane. The cable passes through the tube and the tube passes through the shielding in the refueling port. A clamp on the top end of the tube grips the cable so that a catch on the bottom of the tube stays in the bayonet. A handle is attached near the top end of the tube and allows the operator to apply a torque for operating a bayonet fitting. The tube is drilled to permit insertion of a holding pin which rests on the shielding and positions the tube and the attached parts. The tube is made in two parts so that it may be removed when it is not required.

In use during loop removal, the tube is installed on the cable, pushed against the bayonet and rotated until the catch engages. The clamp is tightened on the cable, and the holding pin is inserted in the tube. The shielding is installed in the refueling port and the bayonet and tube are passed through the hole in the shielding and rested on the holding pin. 
After the loop is moved into the drop tube position, the holding pin is removed, the tube and bayonet are lowered and the bayonet is engaged. The crane is attached to the sling and the loop is lifted. The clamp is loosened, the transfer tool is retracted, and the loop is lowered into the drop tube. A bayonet operating tool is used through a refueling port to release the sling from the loop.

The tool is also used, without the operating tube and shielding, to lift the loop from the drop tube on to the loop transfer tool during loop installation in the reactor. In this case, it is remotely installed in the loop handling extension by the bayonet operating tool.

\subsection{Bayonet Operating Tool}

This long handled tool is manually used from an operator position above the top head shielding through a refueling port to engage or dis engage a loop handling sling bayonet fitting when the fitting is installed in or removed from the loop handling extension.

This tool consists of a long handle assembly, a plier type head with bayonet operating pins attached, and an actuating linkage for the head. This linkage runs from the head through the handle to the operator position. The plier type jaws of the head are bent at $90^{\circ}$ so that they close around the cable of the sling when the cable is vertical. When the jaws close, they are a free fit on the cable and may be slid downward to engage the bayonet operating pins in the holes in the bayonet. The jaws may be locked in the closed position.

If a loop handling sling is to be installed, the bayonet is lowered through the north refueling port approximately 10 feet. The bayonet operating tool is passed through the southeast refueling port and the jaws are placed around the sling cable. The jaws are locked closed, and the tool is slid down until it rests on the bayonet. The tool and sling are lowered together until the bayonet starts into the receptacle in the loop handling extension. Care must be exercised to maintain the cable tight when starting the bayonet. The bayonet operating tool is then rotated and the bayonet operating pins will fall into the holes in the bayonet. The tool is then pushed down and rotated until the bayonet locks into the receptacle.

If a loop handling sling is to be removed, the bayonet operating tool is passed through the southeast refueling port, and the jaws are placed around the sling cable and locked closed. The tool is then slid down until it rests on the bayonet. The tool is turned until the bayonet operating pins fall into the holes in the bayonet. The tool is then pushed down and rotated until the bayonet is free.

\subsection{Canal-to-Cell Lifting Tool}

This tool is used to lift the loop from the thimble into the hot cell and to lower the loop from the cell into the thimble. It is remotely in stalled into the loop handling extension by means of a long handle plier tool. 
The tool consists of a rod with a lifting eye on one end and a bayonet on the other. The bayonet is adapted for insertion and locking in the bayonet receptacle of the loop handling extension, and the eye is suitable for use with the hot cell crane hook.

To install and use the tool, lock the plier tool on the lifting eye and insert the bayonet in the receptacle of the loop handling extension. Turn to the locked position and remove the plier tool. After the loop thimble is elevated into the hot cell, the hot cell crane hook may be inserted into the lifting eye.

\subsection{Refueling Port Viewing Window}

This equipment is used to shield and at the same time provide visibility for the operator observing operations within the reactor vessel during handling of the loops. Also, it may be used during handling of any other component within the vessel, if shielding is required for the observer. It is located in a vessel refueling port.

The viewing window consists of a transparent portion which is surrounded and supported by a structure. This structure rests on the port flange. The design is such that an operator will not be overexposed to radiation during his assigned stay as an observer of loop handling. 


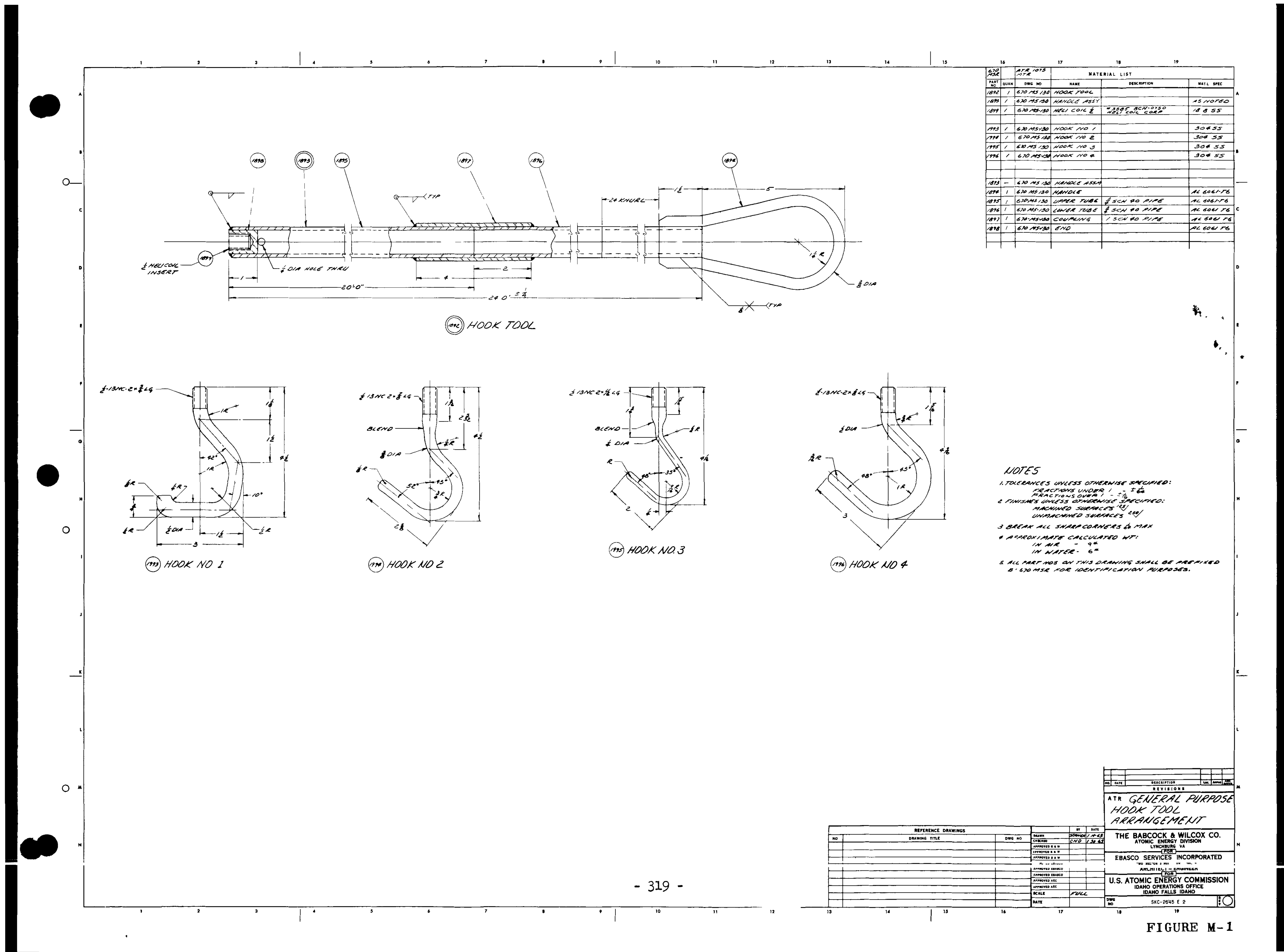




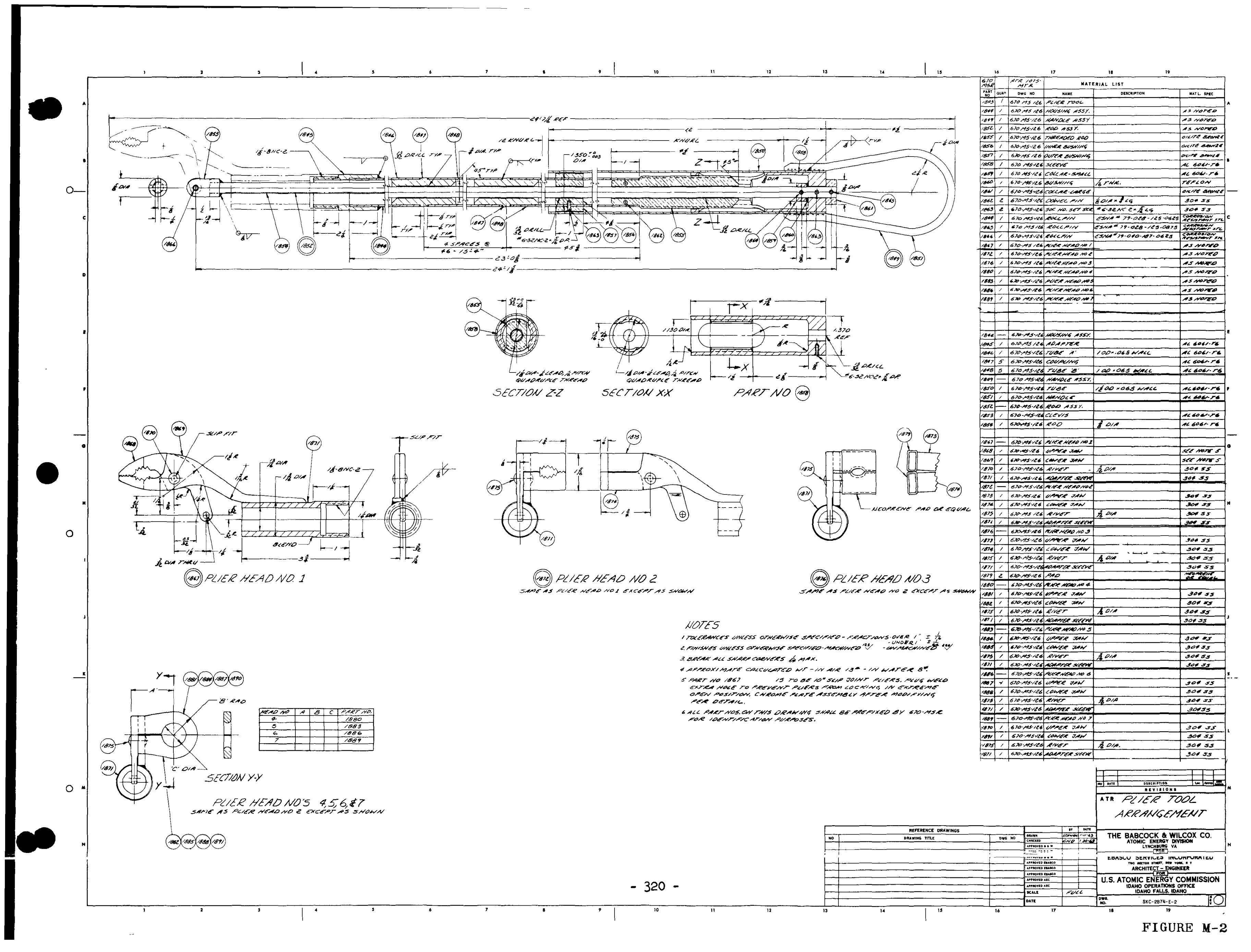




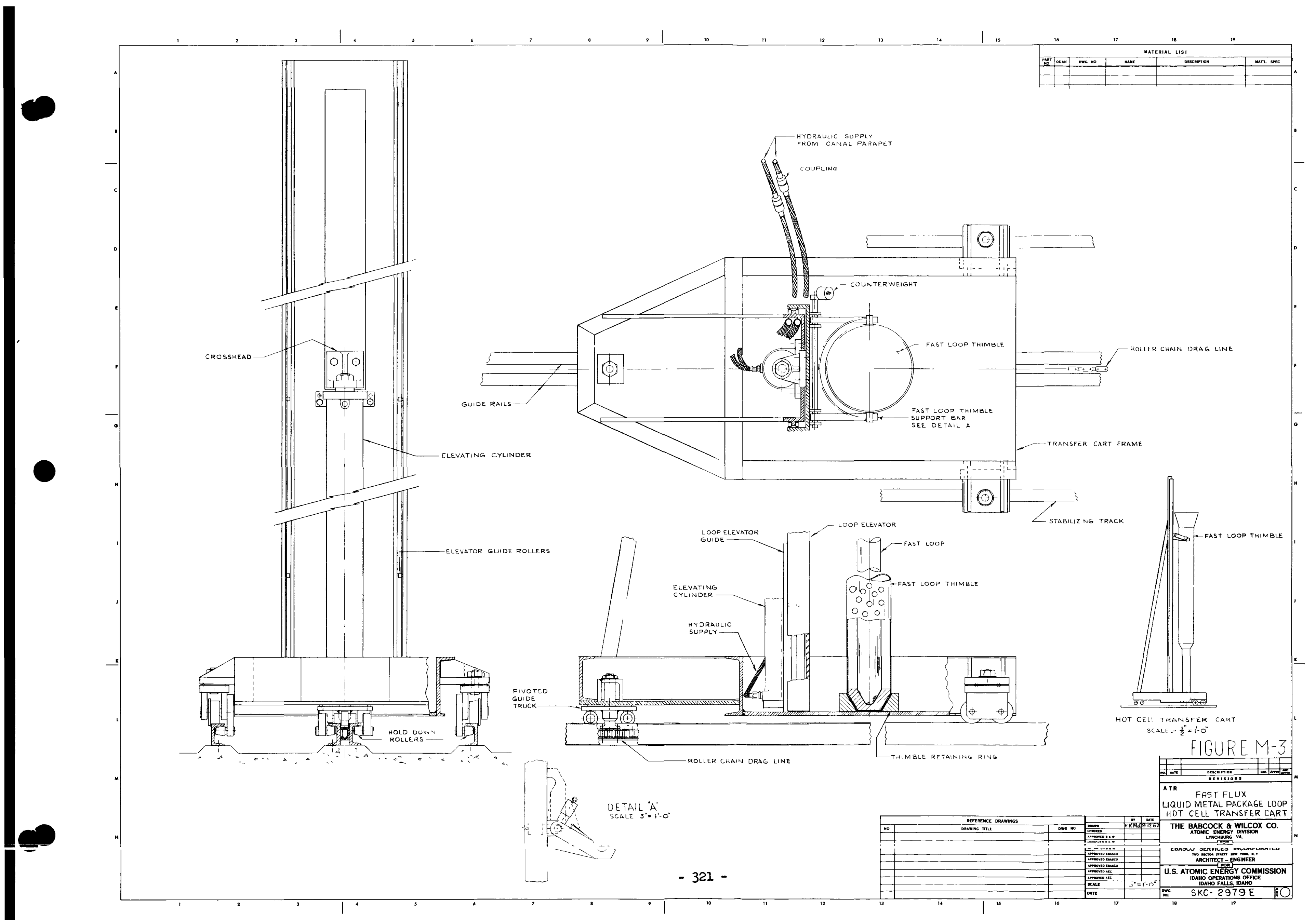



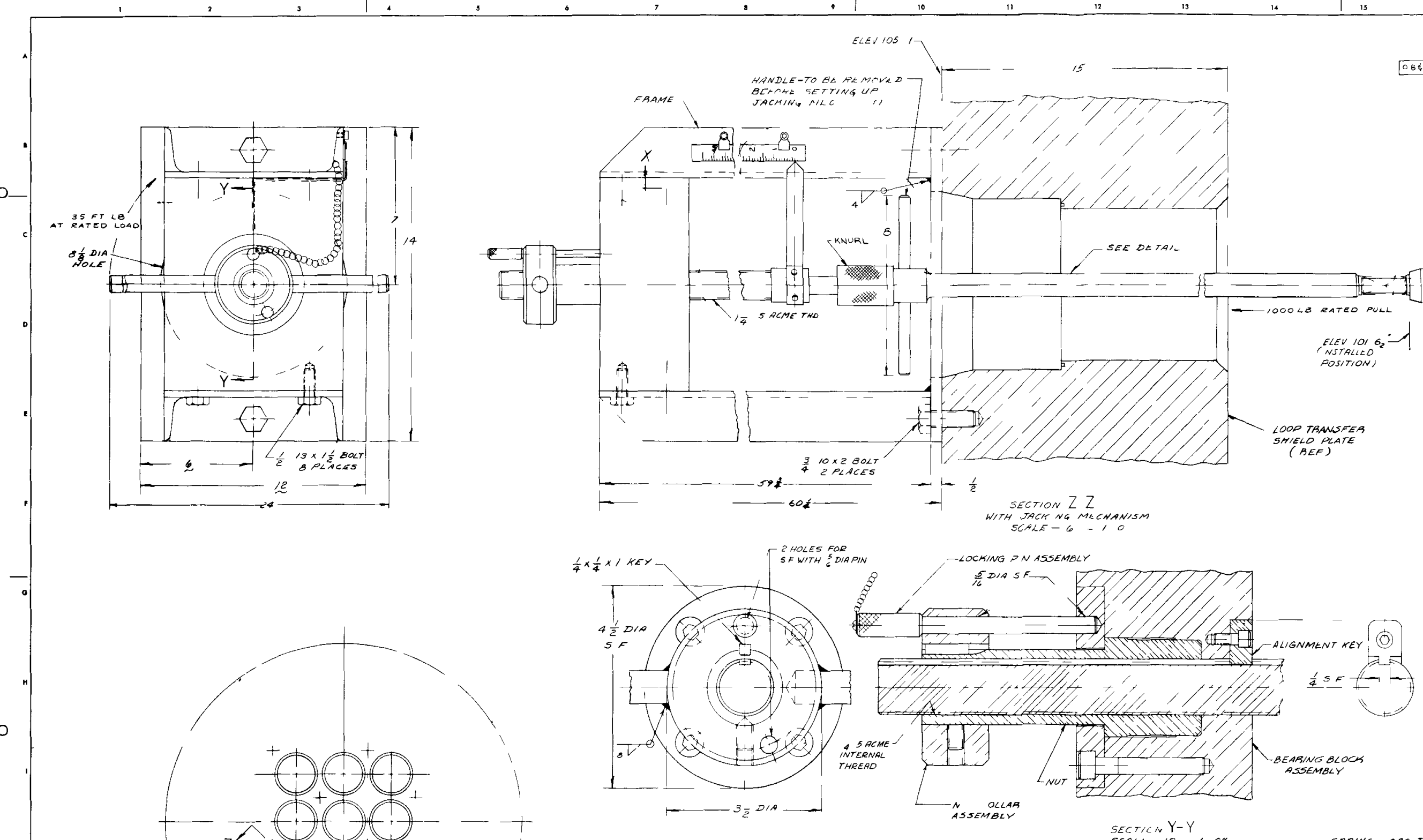

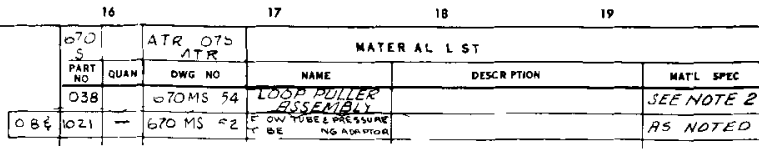

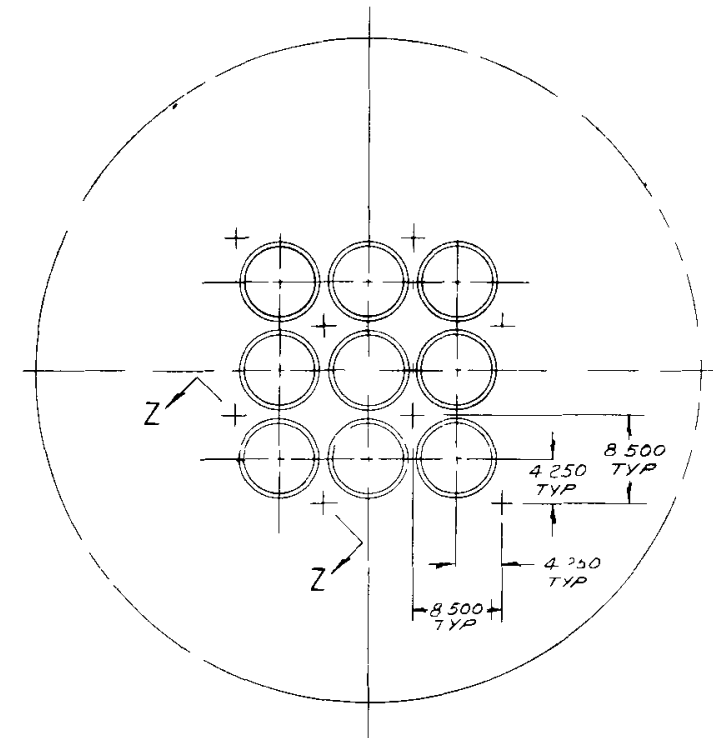

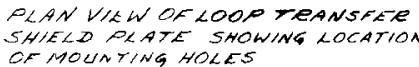

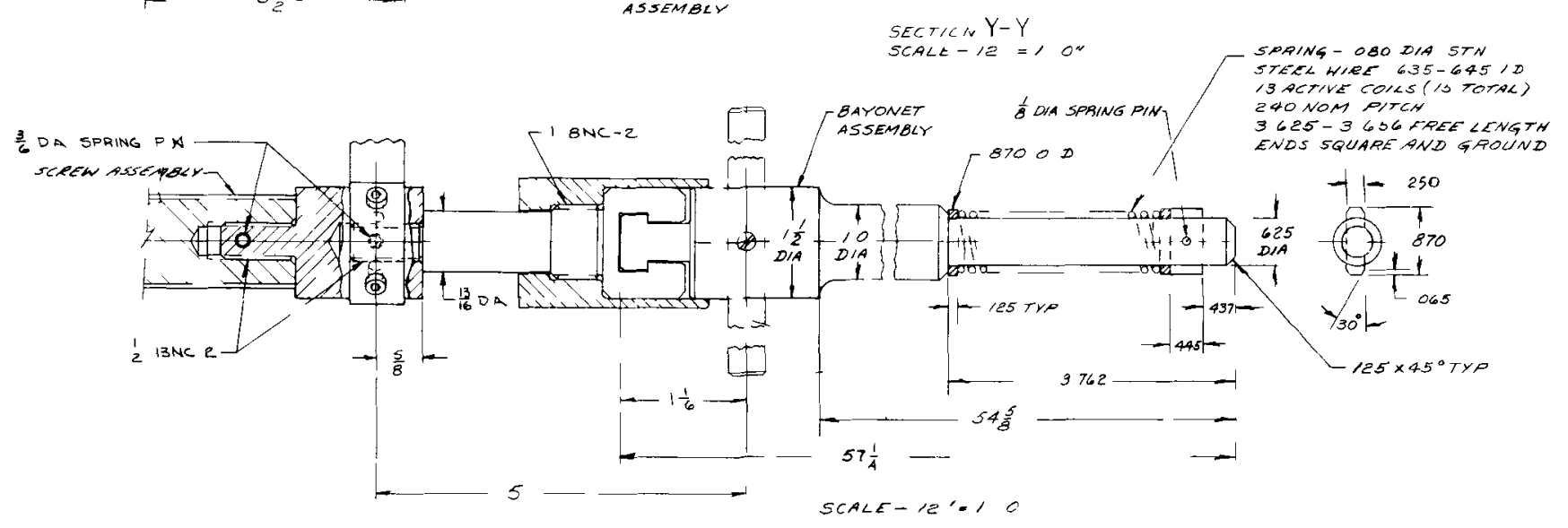

$-324-$

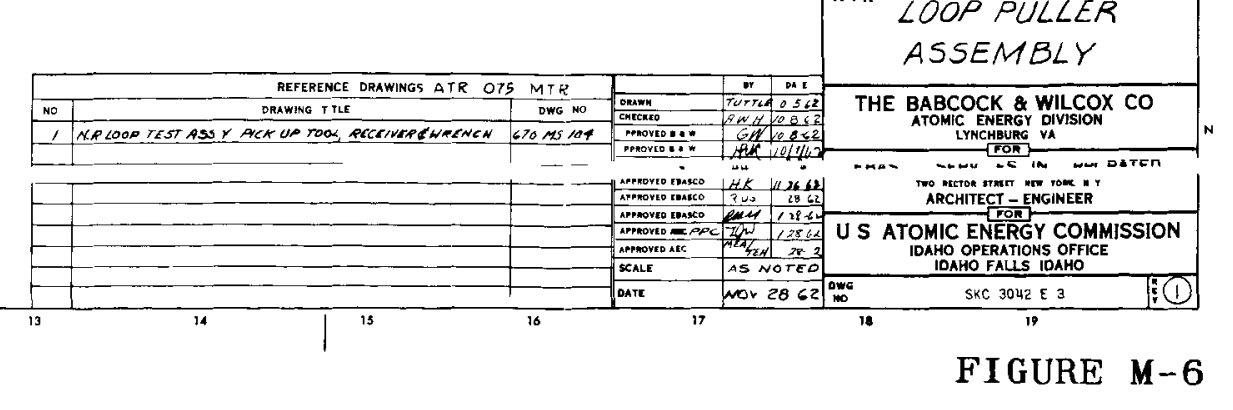

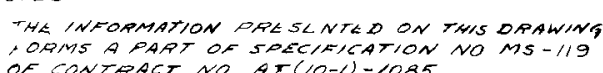

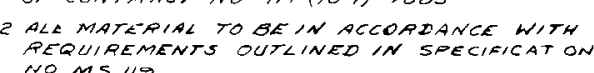

3 QLL DIMENSIONAL TOLEAANCES TOBE

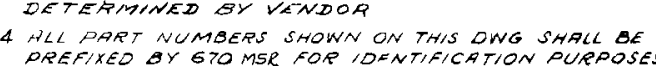
APPROXIMATE CALCULATEO WEIGHT I2O 


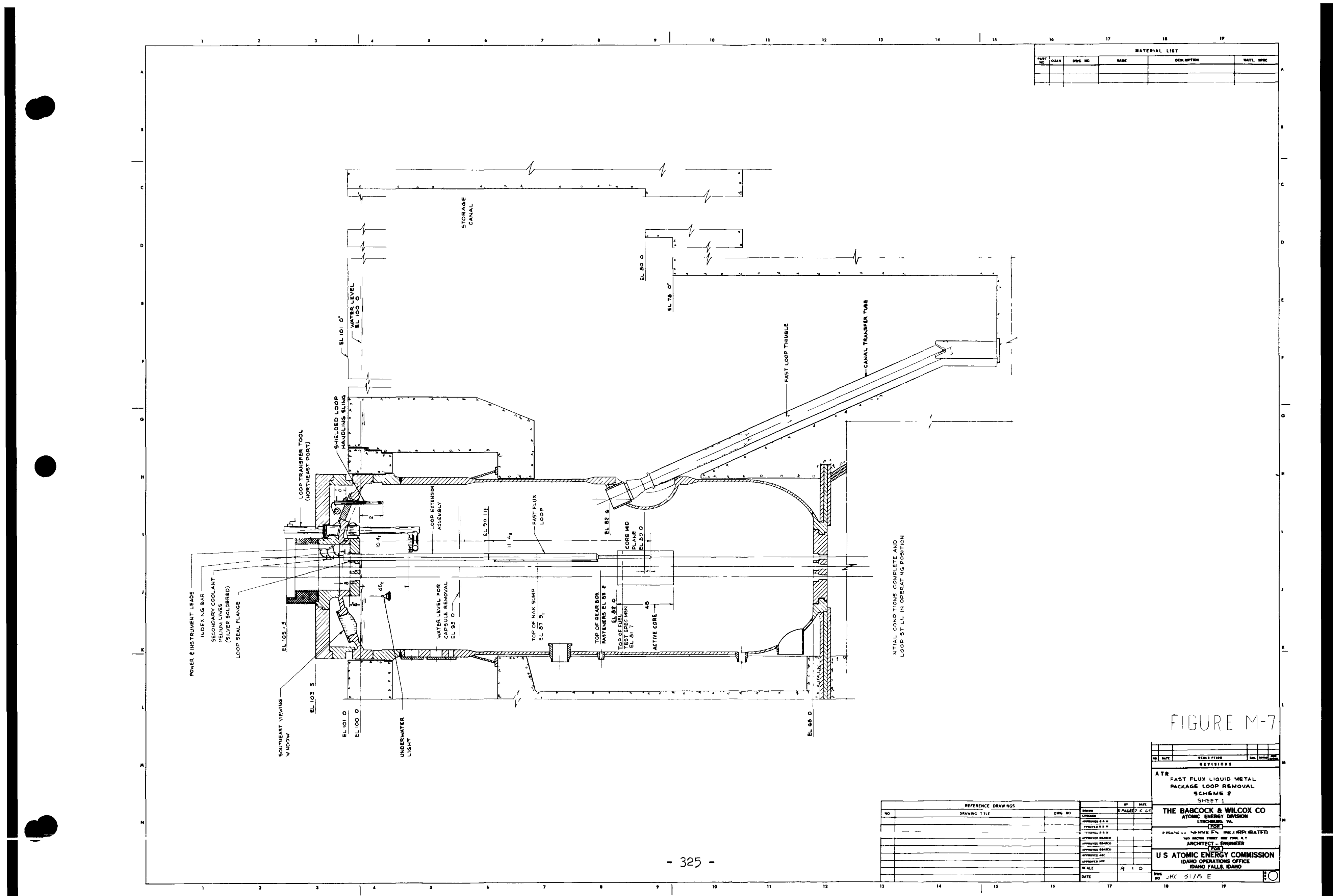




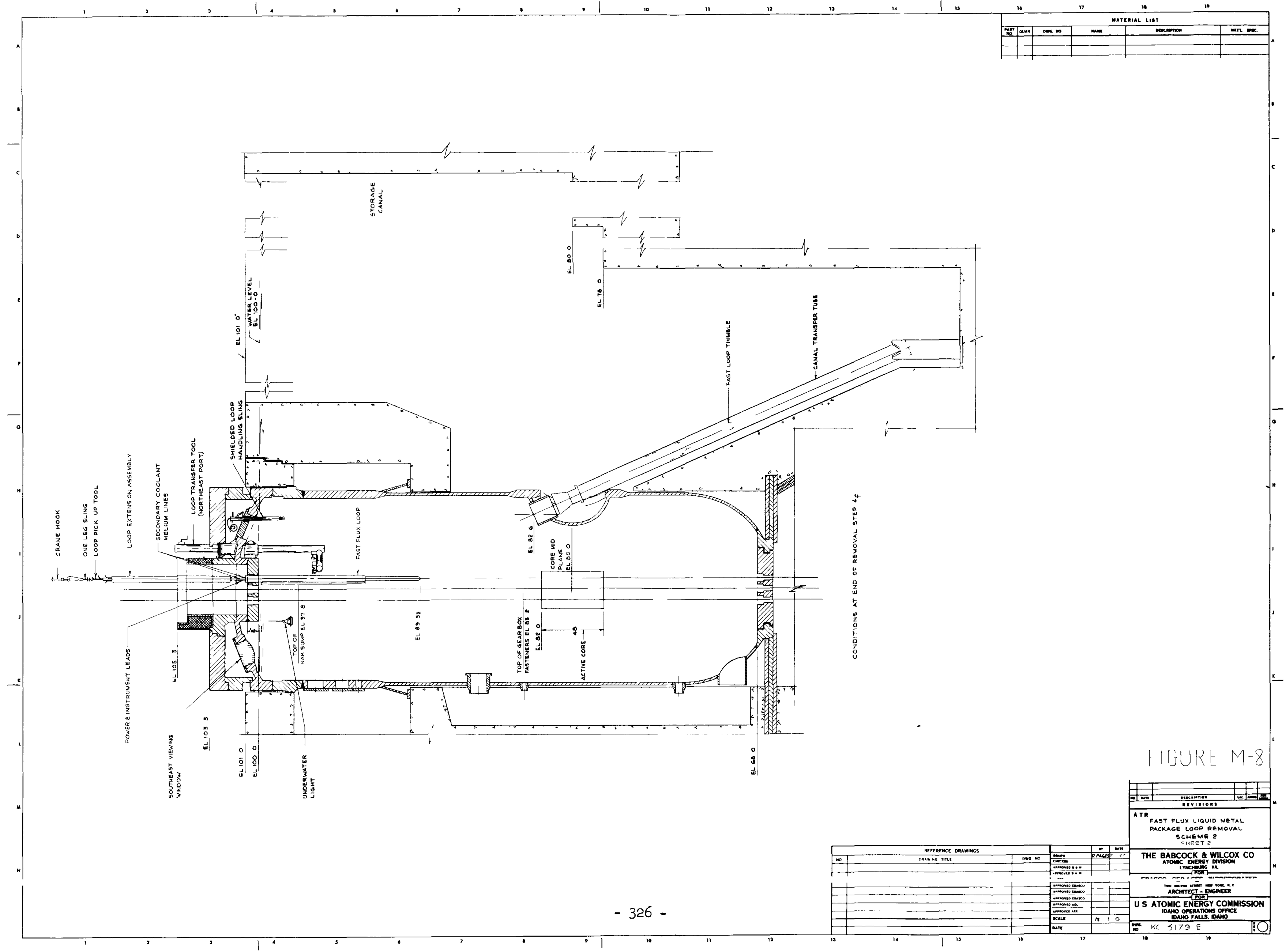




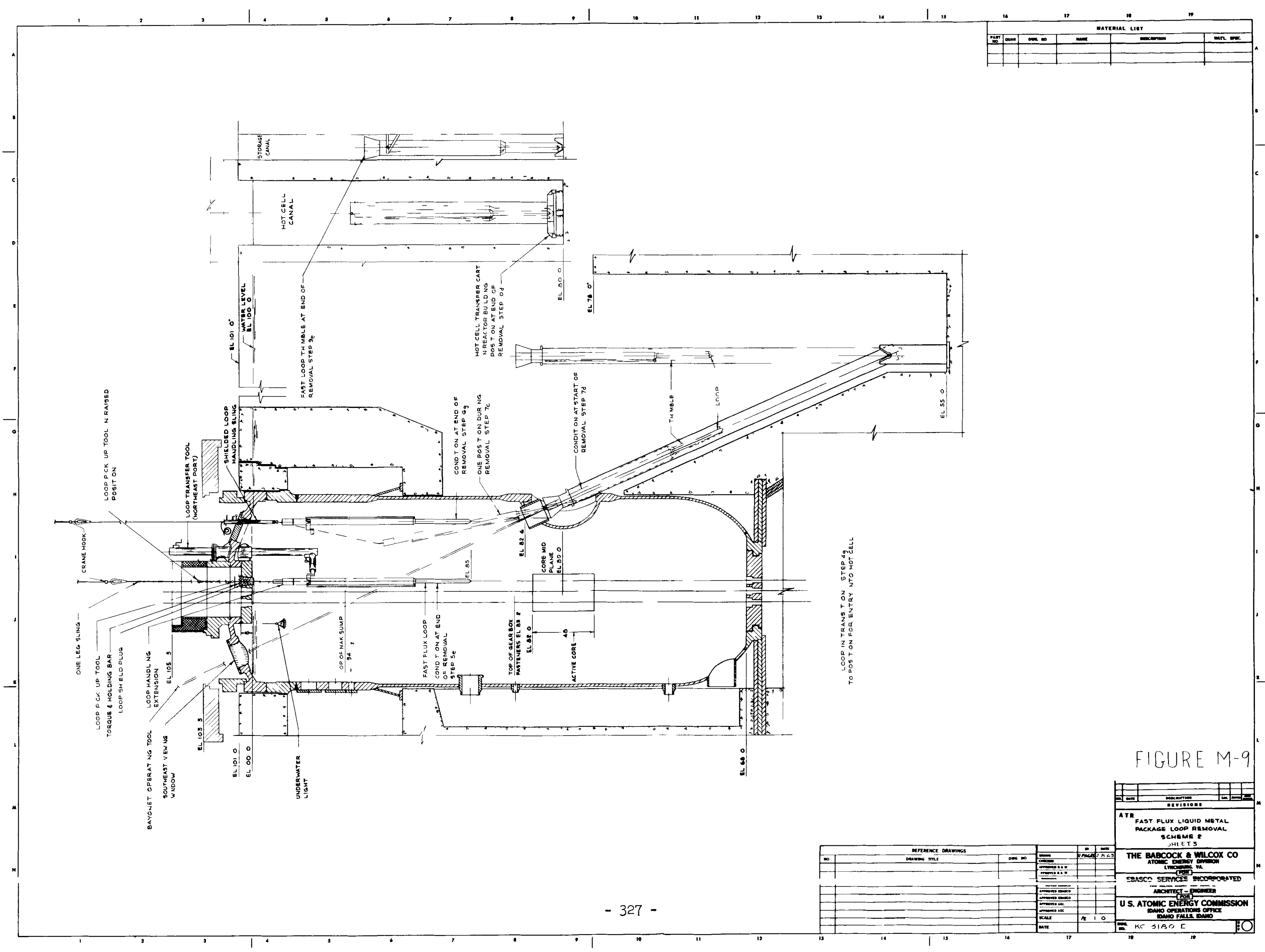




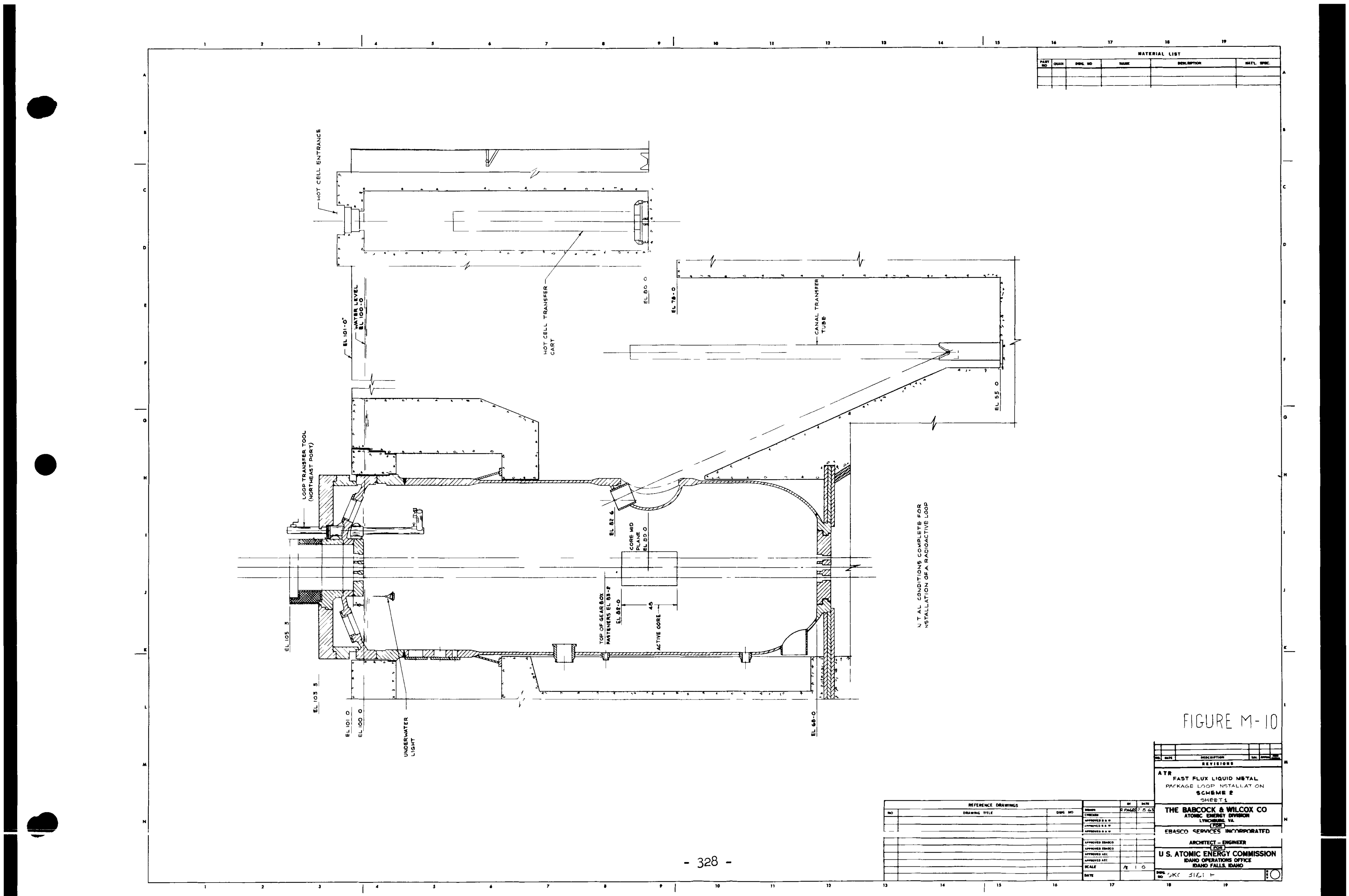




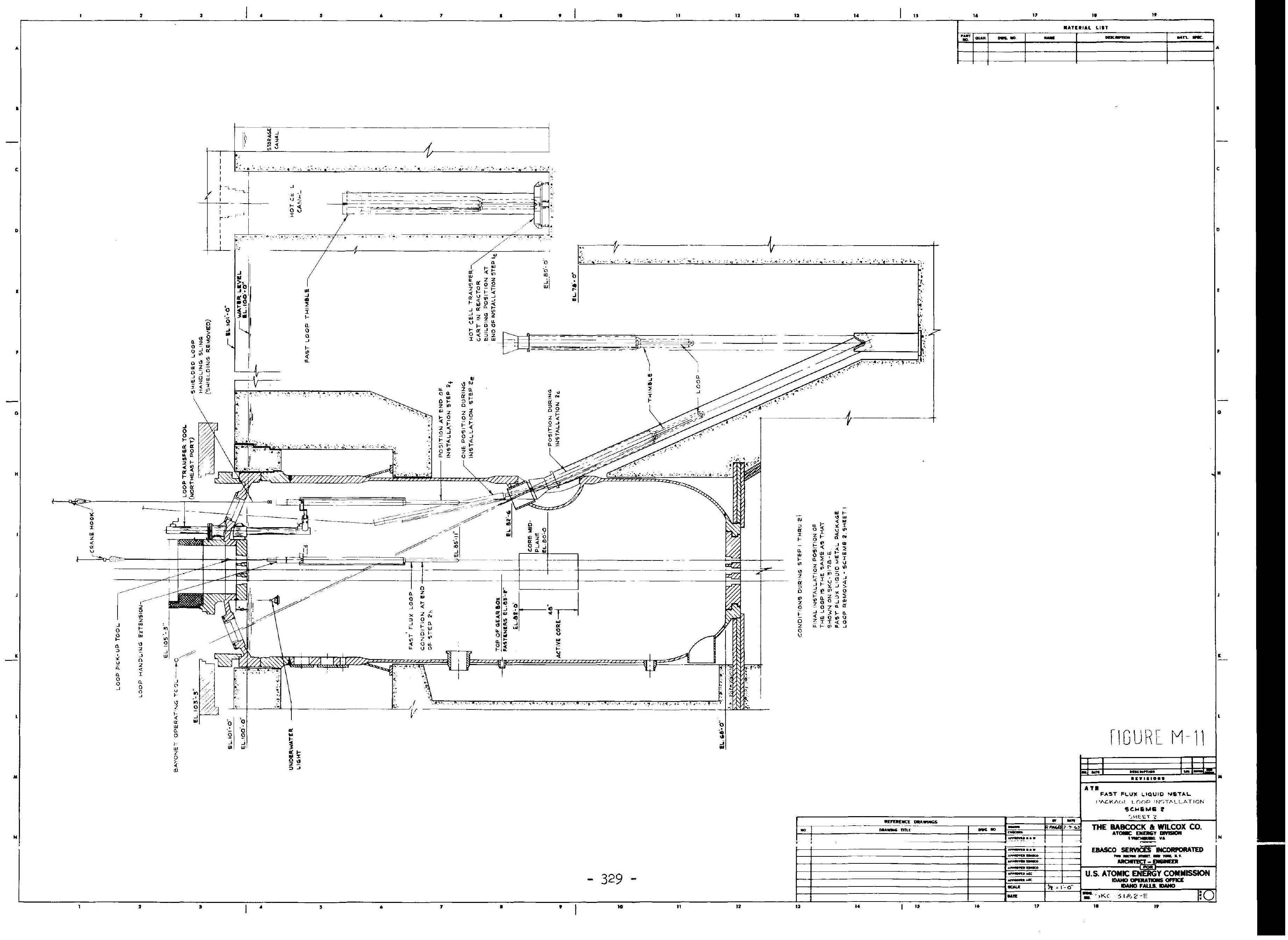


$$
\text { . }
$$ 


\section{APPENDIX N}

Package Loops' Fission Products Gas Inventory 
o

0 


\section{THE BABCOCK AND WILCOX COMPANY \\ FOR EBASCO SERVICES INCORPORATED DESIGN DATA \\ ADVANCED TEST REACTOR \\ PACKAGE LOOPS' FISSION PRODUCT GAS INVENTORY}

\section{Purpose and Scope}

To determine the fission product gaseous activity in the fast flux and thermal flux loops at various times after reactor shutdown. These activities would be of interest primarily in the case of complete cladding defect in the test bundle, permitting the escape of fission product gases to the loop.

\section{General Description}

Gamma rays from fission products are one of the principal sources of after shutdown radiation in the loops. Since fission product gases usually leak from the fuel pins quite readily, tables of gaseous activity for various shutdown times were computed. The calculations are based on a test specimen irradiation time of 10,000 hours.

The fission product activity was computed with the use of a digital computer program which solves coupled time-dependent differential equations describing fission product buildup and decay in a reactor core. The program computes the concentration in a reactor core of each isotope in each of a number of specified fission product chains. It is limited to a maximum of five isotopes in a chain, six fission product buildup times, and six decay times after shutdown.

Case I - Fast Flux Loop

Table I lists the fission product activity in the fast loop at shutdown and six times after shutdown for each isotope of the fission product gases. Gamma activity can be determined by applying the gamma yield in photons / disintegration for each energy to the numbers shown in Table I. The fissile material was considered to be plutonium and specimen power was as sumed to be $150 \mathrm{kw}$.

\section{Case II - Thermal Flux Loop}

Table II lists the fission product activity in the thermal flux loop at shutdown and six times after shutdown for each isotope of the fission product gases. Gamma activity can again be determined by applying the gamma yield in photons/disintegration for each energy to the numbers shown in Table II. The fissile material was considered to be U-235 and specimen power was assumed to be $1,500 \mathrm{kw}$. 
TABLE I

FAST FLUX LOOP FISSION PRODUCT GAS INVENTORY

10, 000 Hours Irradiation

Specimen Power $-150 \mathrm{Kw}$

Isotope

Fission Product Activity - Curies

Time After Shutdown

Shutdown

$12 \mathrm{Hrs}$

$24 \mathrm{Hrs}$

3 Days

30 Days

120 Days

Kr 83m

$1.08\left(10^{2}\right) \quad 1.04\left(10^{2}\right)$

1. $12\left(10^{1}\right)$

$4.05\left(10^{-1}\right)$

2. $58\left(10^{-7}\right)$

Kr $85 \mathrm{~m}$

$2.53\left(10^{2}\right)$

2. $19\left(10^{2}\right)$

$3.81\left(10^{1}\right)$

5. $65\left(10^{0}\right)$

2. $75\left(10^{-3}\right)$

Kr 85

$3.67\left(10^{\circ}\right)$

$3.67\left(10^{\circ}\right)$

$3.67\left(10^{0}\right)$

$3.67\left(10^{\circ}\right)$

3. $67\left(10^{\circ}\right)$

$3.65\left(10^{\circ}\right)$

$3.59\left(10^{\circ}\right)$

Kr 87

1. $04\left(10^{3}\right)$

$6.17\left(10^{2}\right)$

$1.76\left(10^{0}\right)$

2. $94\left(10^{-3}\right)$

2. $30\left(10^{-14}\right)$

Kr 88

1. $52\left(10^{3}\right)$

1. $19\left(10^{3}\right)$

$7.563\left(10^{1}\right) \quad 3.76\left(10^{0}\right)$

2. $29\left(10^{-5}\right)$

Kr 89

$2.28\left(10^{3}\right) \quad 4.90\left(10^{-3}\right)$

Kr 90

$2.79\left(10^{3}\right)$

$4.09\left(10^{-30}\right)$

Kr 91

2. $53\left(10^{3}\right)$

Kr 92

2. $28\left(10^{3}\right)$

Kr 93

$6.34\left(10^{2}\right)$

Kr 94

$6.34\left(10^{2}\right)$

$\mathrm{Xe} 131 \mathrm{~m}$

$3.64\left(10^{1}\right) \quad 3.64\left(10^{1}\right)$

$3,64\left(10^{1}\right)$

3. $63\left(10^{1}\right)$

3. $57\left(10^{1}\right)$

$1.41\left(10^{1}\right) \quad 1.06\left(10^{-1}\right)$

$\mathrm{Xe} 133 \mathrm{~m}$

$1.602\left(10^{2}\right) \quad 1.602\left(10^{2}\right)$

$1.57\left(10^{2}\right)$

$1.48\left(10^{2}\right)$

9. $61\left(10^{1}\right)$

3. $07\left(10^{-2}\right)$

5. $15\left(10^{-14}\right)$

$\mathrm{Xe} 133$

$6.68\left(10^{3}\right)$

$6.68\left(10^{3}\right)$

6. $61\left(10^{3}\right)$

6. $44\left(10^{3}\right)$

5. $31\left(10^{3}\right)$

$1.58\left(10^{2}\right)$

1. $15\left(10^{-3}\right)$

Xe $135 \mathrm{~m}$

$2.09\left(10^{3}\right)$

$1.96\left(10^{3}\right)$

$6.28\left(10^{2}\right)$

$1.81\left(10^{2}\right)$

1. $24\left(10^{\circ}\right)$

$7.88\left(10^{-30}\right)$

Xe 135

$7.73\left(10^{3}\right) \quad 7.65\left(10^{3}\right)$

$5.32\left(10^{3}\right)$

2. $79\left(10^{3}\right)$

1. $06\left(10^{2}\right.$

$7.47\left(10^{-20}\right)$

Xe 137

$6.27\left(10^{3}\right) \quad 1.61\left(10^{-1}\right)$

$\mathrm{Xe} 138$

$6.59\left(10^{3}\right)$

$5.73\left(10^{2}\right)$

1. $18\left(10^{-9}\right)$

$2.12\left(10^{-22}\right)$

Xe 139

5. $57\left(10^{3}\right)$

2. $17\left(10^{-23}\right)$

$\mathrm{Xe} 140$

$4.28\left(10^{3}\right)$

Xe 141

$2.53\left(10^{3}\right)$ 
TABLE II

THERMAL FLUX LOOP FISSION PRODUCT GAS INVENTORY

10, 000 Hours Irradiation

Specimen Power - 1,500 Kw

Isotope

Fission Product Activity - Curies

Shutdown $1 \mathrm{Hr}$ 12 Hrs 24 Hirs 3 Days 30 Days 120 Days

$\mathrm{Kr} 83 \mathrm{~m}$ $6.03\left(10^{3}\right) \quad 5.84\left(10^{3}\right)$

$6.22\left(10^{2}\right)$

2. $26\left(10^{1}\right)$

1. $44\left(10^{-5}\right)$

$\mathrm{Kr} 85 \mathrm{~m}$

$1.89\left(10^{4}\right)$

$1.63\left(10^{4}\right)$

2. $83\left(10^{3}\right)$

4. $21\left(10^{2}\right)$

2. $04\left(10^{-1}\right)$

Kr 85

$2.73\left(10^{2}\right)$

$2.73\left(10^{2}\right)$

2.73(10 $)$

$2.73\left(10^{2}\right)$

2. $73\left(10^{2}\right)$

$2.71\left(10^{2}\right)$

2. $67\left(10^{2}\right)$

Kr 87

3. $39\left(10^{4}\right)$

$2.02\left(10^{4}\right)$

$5.74\left(10^{1}\right)$

$9.60\left(10^{-2}\right)$

7. $51\left(10^{-13}\right)$

Kr 88

4. $65\left(10^{4}\right)$

$3.63\left(10^{4}\right)$

$2,313\left(10^{3}\right)$

1. $15\left(10^{2}\right)$

$7,01\left(10^{-4}\right)$

Kr 89

5. $78\left(10^{4}\right)$

1. $24\left(10^{-1}\right)$

Kr 90

$6.54\left(10^{4}\right)$

$9.60\left(10^{-29}\right)$

Kr 91

4. $65\left(10^{4}\right)$

Kr 92

3. $39\left(10^{4}\right)$

Kr 93

1. $63\left(10^{4}\right)$

Kr 94

$7.54\left(10^{3}\right)$

$\mathrm{Xe} 131 \mathrm{~m} 4.20\left(10^{2}\right)$

$4.20\left(10^{2}\right)$

$4.20\left(10^{2}\right)$

4. $19\left(10^{2}\right)$

4. $13\left(10^{2}\right)$

1. $64\left(10^{2}\right)$

1. $24\left(10^{\circ}\right)$

$\mathrm{Xe} 133 \mathrm{~m} 1.96\left(10^{3}\right)$

$1.96\left(10^{3}\right)$

$1.92\left(10^{3}\right)$

$1.81\left(10^{3}\right)$

1. $18\left(10^{3}\right)$

$3.76\left(10^{-1}\right)$

6. $294\left(10^{-13}\right)$

$\mathrm{Xe} 133$

1. $65\left(10^{5}\right)$

1. $64\left(10^{5}\right)$

$1.59\left(10^{5}\right)$

1. $52\left(10^{5}\right)$

1. $21\left(10^{5}\right)$

3. $54\left(10^{3}\right)$

$2.57\left(10^{-2}\right)$

$\mathrm{Xe} 135 \mathrm{~m} 2.22\left(10^{4}\right)$

$2.09\left(10^{4}\right)$

$6.69\left(10^{3}\right)$

$1.93\left(10^{3}\right)$

1. $32\left(10^{1}\right)$

$8.39\left(10^{-29}\right)$

Xe 135

1. $57\left(10^{5}\right)$

1. $51\left(10^{5}\right)$

$8.70\left(10^{4}\right)$

4. $20\left(10^{4}\right)$

1. $46\left(10^{3}\right)$

$1.01\left(10^{-18}\right)$

Xe 137

$7.05\left(10^{4}\right)$

$1.79\left(10^{0}\right)$

Xe 138

$6.91\left(10^{4}\right)$

$6.01\left(10^{3}\right)$

1. $24\left(10^{-8}\right)$

2. $23\left(10^{-21}\right)$

Xe 139

$5.91\left(10^{4}\right)$

2. $29\left(10^{-22}\right)$

Xe $140 \quad 4.65\left(10^{4}\right)$

Xe 141

2. $26\left(10^{4}\right)$ 